\title{
From Horse and Buggy to GPS: \\ Life on a Saskatchewan Farm
}

\author{
By \\ Roderic Beaujot
}

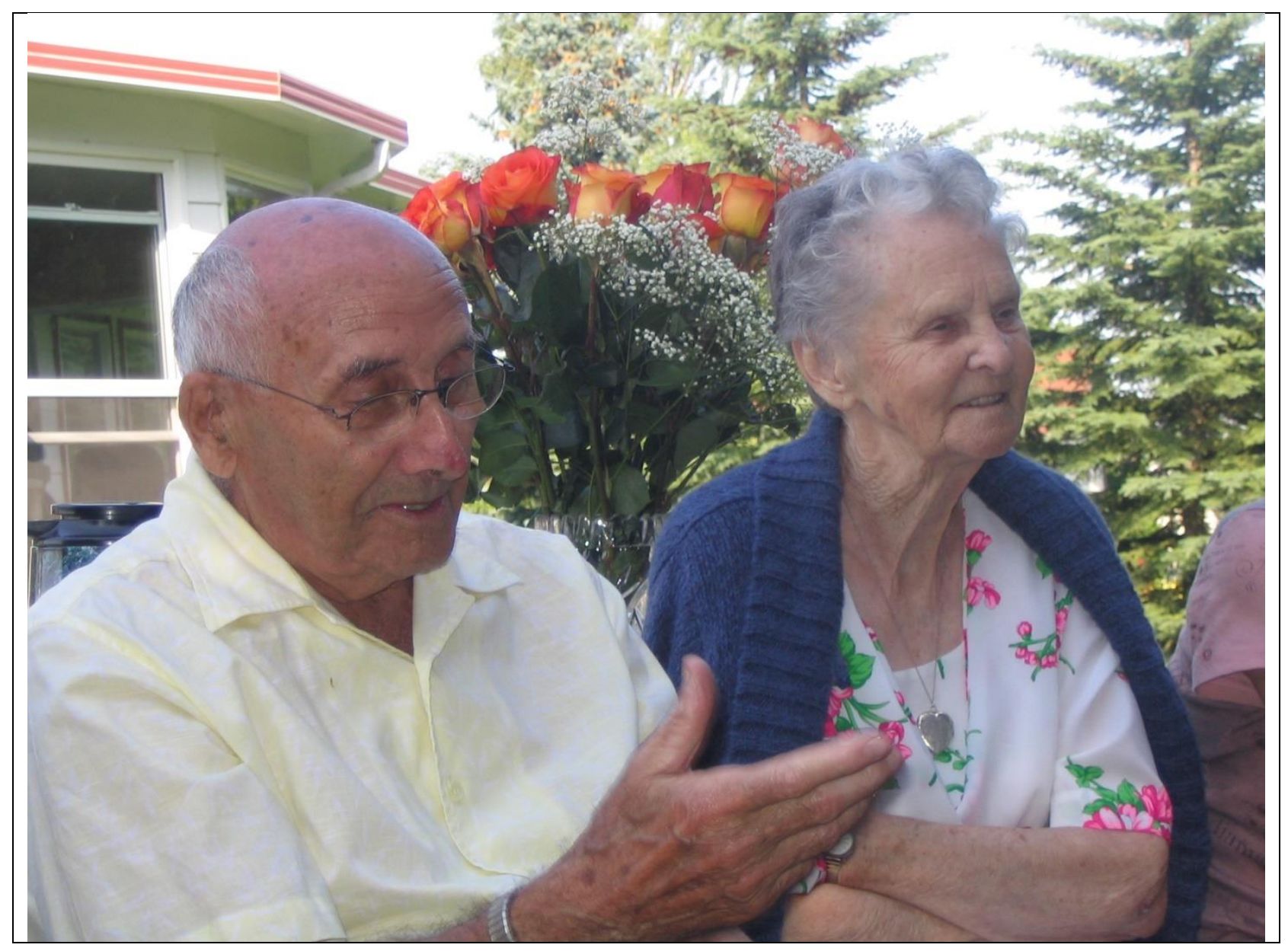

Dorothy and Leon Beaujot, Kipling, Saskatchewan, Canada, 2007

Dated: 19 March 2021 


\title{
From Horse and Buggy to GPS: \\ Life on a Saskatchewan Farm
}

\author{
Roderic Beaujot
}

\begin{abstract}
:
This book tells the story of my parents and grandparents, from horse and buggy days to increasing specialization and mechanization in agriculture. My grandparents, Félicien and Bertheline Beaujot and Paul and Julienne Mullie arrived in Canada from Belgium and France over the period 1892 to 1911.

After treating the conditions that allowed for European settlement in Western Canada, I summarize the history of the community of Saint Hubert in Southeastern Saskatchewan, where my grandparents lived their lives and my parents Leon and Dorothy Beaujot were married (1945) and are buried (2014). Originally called "La Rolanderie," this settlement was established in the mid-1880s by "French counts" who sought to start a new life on the prairies of what was then Canada's North West. While the aristocrats soon returned to Europe, they and others who came at that time had started a vibrant community that has since essentially disappeared, with only the church and cemeteries remaining.
\end{abstract}

This story of my parents and grandparents shows how life changed on family farms: shelter and food, earning a living, family and community.

Copyright $(C$ by Roderic P Beaujot, Emeritus Professor of Sociology, Department of Sociology, University of Western Ontario, London ON N6A 5C2 Canada

Genre: Biography, History

Period covered: $1885-2014$

Key words: change in agriculture, church, community, education, family, farm, farming, French, language, Saskatchewan, settlement

Available as paperback (print on demand) at www.Lulu.com

Preprint with Open Science Framework (OSF) at SocArXiv: Beaujot, Roderic P. 2021. From Horse and Buggy to GPS: Life on a Saskatchewan Farm. https://doi.org/10.31235/osf.io/nzcwe

ISBN: 978-1-7775989-0-7 (paperback)

Dated: 19 March 2021 


\section{Contents}

Forward by Henry Gobeil 3

Preface 4

Acknowledgements 5

Introduction 6

ONE Historical Context of European Settlement in Western Canada 11

TWO Saint Hubert, Saskatchewan 18

THREE The Four Families of Origin in Belgium and France: Beaujot, Sénéchaud, Mullie, Smets 41

FOUR Leon Beaujot and the family of Félicien and Bertheline (née Sénéchaud) Beaujot 101

FIVE Dorothy Mullie and the family of Paul and Julienne (née Smets) Mullie 121

SIX Leon and Dorothy Beaujot: The family farm, 1945-1985 148

SEVEN Retirement Years: Travel, Family, Reflections, 1986-2014 199

References 250

3.1. Beaujot family genealogy 87

3.2. Sénéchaud family genealogy 90

3.3. Mullie family genealogy 93

3.4. Smets family genealogy 97

5.1 Letters written by Marie Louise, Jean, Raymond and Dorothy, 1924-25 145

6.1-6.5. Tables derived from farm account books of Leon and Dorothy Beaujot, 1943-1977 195

7.1. Beaujot-Mullie Reunion at Camp O'Neill, 4-7 August 2000231

7.2. Old St. Hubert Cemetery 232

7.3. Mike and Jeanne Mullie celebrate the $60^{\text {th }}$ Anniversary of their marriage on 28 December 1944234

7.4. Stories by the decade: talks given by their children at Leon and Dorothy Beaujot's $60^{\text {th }}$ Wedding Anniversary, 14 July 2005237

7.5. Email exchanges in the family at the time of Dorothy's decease, 4-6 March 2014246

\section{List of Boxes}

3.1. Two early generations of the Beaujot family, Dinant, Belgium 43

3.2. Four families of origin: Three generations 85

5.1. Trophies - Paul Mullie 127

5.2. Michel Mullie: Military Service 136

7.1. Cars, trucks and miles 202

7.2. Dorothy Beaujot: Did I tell you about our grandchildren 208

7.3. Leon Beaujot: On my children and their spouses 214

7.4 Dorothy Beaujot: The olden days in Golden Plain 216

7.5. Dad's Last Day by Jeanette Beaujot 228 


\section{Forward}

The Beaujot family appeared on my radar in 1959. I remember well this little man with dark complexion, and a taller woman who looked like my mother in her younger days, with several children in tow. It was early September; the place was Collège Mathieu in Gravelbourg, Saskatchewan. This family was doing the same thing my parents had done a few hours earlier: enrolling their son at this bilingual boarding school. That boy, Roderic, became, and was my best friend throughout our eight years at college, brothers from different parents, and our friendship endured through the decades that followed.

I feel privileged to have been asked to review and comment on this story as it unfolded. An amateur of history and genealogy, this evolving family history fit right into my interests and passion. It's been years in the making, but Roderic has been meticulous and professional in his research, leaving no stone unturned, and artful in his delivery. The narrative contributions of his parents, siblings, and others, enhance the interest and validity. This book is a historical document, a genealogy, and a narration of a Saskatchewan farm family in the $20^{\text {th }}$ century.

The central theme of this book is the family of Leon and Dorothy Beaujot, but like a river that flows in time, it has tributaries nourishing this family unit: the Beaujot, Sénéchaud, Mullie and Smets ancestral origins. Families sourcing from different origins, under different circumstances, lives evolving differently, they are "very different but much the same." We learn the push and pull of their immigration: the push of the conditions back in Europe, the effects of war, and the pull of owning land in the new country. Down river is the turbulent difficulties of homesteading in a strange country, through to a "century of change in prairie farming".

As accurate as GPS, Roderic locates his family in the Saint Hubert community, with a history of fur trade, treaties, French counts, and settlers from Belgium and France. It's interesting how he compares the geography and climate of his ancestors' communities, to this prairie land of unknown qualities. It's a story of survival, and of resilience, doing what one had to do to feed the family, and to try to make life better for their offspring. It's a story of adaptation, of learning the secrets of the land, learning nature's ways, and through trial and error, developing the best practices of managing land and beast. It's a story of the importance of community, the challenges and hardships facing the settlers, and how the institutions of church and school united them in mutual support, in work or in entertainment.

We owe so much to our ancestors, who figuratively and literally "paved the way" for us, in clearing the land, in building communities, in reaping the benefits we enjoy today. Descendants of Leon and Dorothy Beaujot will have here the opportunity to meet their ancestors, and to learn what they have done to make life easier for them. They will learn history and hear stories of life a century ago. They will appreciate the courage, the ingenuity, and the persistence of their elders. This is a family to learn from and to emulate: their democratic parenting style, involving everyone in decision-making, the cooperative approach to farming, the family traits of record keeping, documenting, identifying lessons learned, critical analysis, and making improvements. The story-telling and humorous anecdotes in these pages, quotations of Leon, Dorothy, or of their children at family events, attest to this loving couple's legacy, and the harmonious 
family relationships they fashioned. I would expect this book to be cherished, and to be passed down from generation to generation, an heirloom like the family bible was in yesteryear.

Thanks to Leon's foresight in encouraging Roderic to document the family history. Thanks to Dorothy for instilling the art of record keeping, Thanks to this couple's humorous story-telling practice, this family's story is being preserved.

Apart from the historical and familial interests of this document, it has great entertainment value. I remember reading the chronicles of the families of origin with excitement. Bertheline Sénéchaud, Leon's mother, is my heroine. I admire the courage this young girl had, absconding from home, from family and country, to take on this huge adventure on her own: sailing to Canada, to meet and marry a man she'd love. These humanistic episodes, and the lessons we can learn from this family, would be of interest to any reader, whether or not a family member.

Henry Gobeil

Weyburn, Saskatchewan

31 January 2021

\section{Preface}

This book started with stories that our parents told us over the years. These stories tell us much about farming and sustaining life on the Prairies over the years: keeping warm, feeding the family, making a living, raising and educating children, creating community.

The memories go back to our four grandparents who were also from farming backgrounds in Belgium and France. Arriving in Saskatchewan in the period 1892 to 1911, both sets of grandparents were married in the same year (1910), and they lived in the same small parish in Saskatchewan (Saint Hubert), where Leon Beaujot and Dorothy Mullie were married (1945) and buried (2014).

I distributed an 80-page version of this manuscript at the time of my father's $90^{\text {th }}$ in 2009 , under the title Ninety Years of Memories: Leon and Dorothy Beaujot. As the title was being chosen, Dorothy said that a better title would be "I can't remember" and Leon added, "Lest we forget."

A reader of this first edition suggested that I include a family tree, placing the members of our extended family in context. I decided to include genealogical information on all my parents' uncles, aunts and first cousins (see Appendixes 3.1 to 3.4 at the end of Chapter 3). This turned out to be quite an adventure, taking me to Malvoisin (Province of Namur), Ploegsteert (Province of Hainaut) and Sint Truiden (Province of Limburg) in Belgium, and La Chapelle-Bertrand (Département of Deux-Sèvres) in France. Besides the genealogical information (birth, death, marriage, children), I sought to say a little about each of my parents' uncles and aunts, and their children (first cousins of my parents). I took particular interest in those who were farmers, and on how people were affected by the wars of 1914-18 and 1939-45. 
To provide further context, I added a chapter on the Roman Catholic Parish of Saint Hubert, Saskatchewan. Originally called La Rolanderie, this community was founded by a dozen "counts" from France. In his book on Belgian settlement in Western Canada, historian Cornelius Jaenen (2011) calls it a "utopian settlement". While the aristocrats soon returned to Europe, other immigrants, mostly from Belgium and France, built a community that would grow to some 320 parishioners in the 1950 s. The parish was closed at its $100^{\text {th }}$ anniversary in 1990 , with only the church and cemeteries remaining.

\section{Acknowledgements}

Thanks to Henry Gobeil, my friend from our days at Collège Mathieu in Gravelbourg, Saskatchewan, for his encouragement, generous support and insights of various kinds, throughout this project. My second debt of thanks goes to Damien Beaujot, my son and chief editorial assistant. I did not cut all the tangential thoughts that Damien had proposed, but readers will be glad that some of them are now in footnotes. A special thanks to my brothers and sisters, Norbert, Fred, Honory, Leona, Doreen, Adelin, Pat and Jeanette, who let me use their stories and insight. Among my first cousins, thanks especially to Joe Driscoll, Jack Driscoll, Cyril Laforge, Betty Hameluck and Annette Gunn, for their generous suggestions and additions. For the more extended family, in Belgium, France and Canada, I am indebted to my parents' first cousins Maurice Godart, Bernadette Gatin, Alice Martin, Jean Mullie and Lucien Dutois; to my second cousins Jules Parent, Denis Payot, Victor Gatin, Jean-Yves Ménage, André (Dédé) Largeau, Jocelyn Molton, Louise Mullie, Lutgarde Vendrickx, Ria Weets, Luc Weets; also to Martine Parent (daughter of my second cousin Marthe Parent) and Martin Ménage (son of my second cousin Maryvonne Ménage).

Thanks to Sylvain and Anne Dumonceaux, my parents' neighbours, for the lovely anecdotes, and for checking on errors. Boyd Metzler sent information on Saint Hubert from the Whitewood Historical Museum. Sister Therese Leclair, Sister of Our Lady of the Cross, explained the food production, preservation and cooking at the Saint Hubert Joan of Arc Home. Brian Standingready, of the White Bear First Nation and Anita DeLorme, of the Cowessess First Nation, helped me understand the Indigenous presence in the Pipestone Valley before the arrival of Europeans, and the land transfers following on the 1992 Saskatchewan Treaty Land Entitlement Framework Agreement. Betty Adam (née Blunt) followed up on Memories of St. Hubert 1980, for which she had been the chief instigator and editor. Historians Peter Neary, Roger Emerson and Michelle Hamilton were most generous in their comments and suggestions. Among the many errors that she corrected, Elisabeth Beaujot, my spouse, ensured that I did not convert threshing machines into thrashing machines. All errors and omissions are my responsibility.

Roderic Beaujot, London, Ontario, February 2021 


\section{Introduction}

On seeing the ice that was used for icebox refrigeration, after their 1911 arrival at Saint Hubert, Saskatchewan, my grandmother Julienne Mullie wondered how people could survive in a climate that produced ice of such thickness. Little did she realize at the time the she would spend the rest of her life in the district. In 1919, my grandfather Félicien Beaujot moved his young family from Saint Hubert to California, under recommendation from a doctor who thought a more humid climate would reduce his debilitating migraine headaches. The family arrived when the Spanish flu was rampant and they made a solemn promise, should they recover, to return to the Saint Hubert Parish. It thus came to be that my grandparents on both sides, as well as my parents, came to live out their lives in the district of Saint Hubert.

This book started with stories told by my parents, Leon and Dorothy Beaujot. While these stories often focus on hardships and achievements, they also tell us much about a century of change on Prairie family farms and farming communities. I pay particular attention to the demographics, to the changes in earning a living as farmers, and in maintaining a household to shelter, feed and care for family members. As seen in my Earning and Caring in Canadian Families, I like to think of earning a living and caring for family members as the central activities of families. This ensures the reproduction of life from one generation to the next. The lives of my parents and grandparents, and the community of Saint Hubert, provide examples of how earning and caring evolved for farm families over a period of 125 years (approximately 1885 to 2010 ) in this part of the world.

Chapter 1 gives a short historical context of European settlement in Western Canada. This includes the National Policy (1879) that displaced the previous geo-political arrangements, based on Indigenous and Métis Peoples, in favor of transcontinental links of transportation, resource extraction and settlement by peoples of European origin. Through the Free Grants and Homestead Act (1868), and a grid system to locate specific ownership, the prairies of Western Canada were valued for grain and livestock production rather than the undomesticated animals and plants that could be harvested from the land. This agricultural development required new varieties of grain that could mature in the short period between the last frost of the spring and the first frost of the fall.

The European settlement of the prairie region has been described as "block settlement," with people of a given ethno-religious origin typically occupying specific areas. As elaborated in Chapter 2, Saint Hubert started in 1885 as La Rolanderie in the newly created District of Assiniboia in Canada's North-West. With the formation of a French-speaking parish in 1890, this small area of southeastern Saskatchewan became an area of French-speaking settlement. Founded in 1890, the parish of Saint Hubert was served in 1903-1961 by the Fils de Marie Immaculée, an order of priests and brothers from France. There would be as many as four priests in residence at the same time, also serving other neighboring communities from the rectory at Saint Hubert. The community grew to some 60 families and 320 people in the early 1950s. Besides the priest's residence, the small hamlet included 14 private homes, plus a nursing home that had 11 Sisters of Our Lady of the Cross and 80 patients when it closed in 1968. After 1970 when the 
priest's residence was moved to Whitewood, and the general store and garage were closed, there were no longer any residents in the small hamlet. The parish itself closed after celebrating its $100^{\text {th }}$ anniversary in 1990, and in 2017 there were 17 families and 50 people living in the district. Although Saint Hubert has all but disappeared, it remains present in the written records, where the Beaujot and Mullie names are also found.

In his chapter on "French Settlements," after treating francophone Métis settlements and Northern Settlements, Anderson (2013: 268-269) observes that the first of the Southern Settlements was doubtless "the most interesting": Saint Hubert or La Rolanderie. He mentions two graduates in agriculture from the Université de Louvain arriving in 1908 and 1911 (this would be François Smets and his brother-in-law Paul Mullie), and that farmers with French surnames are still found around St. Hubert: Boutin, Dumonceaux, Jeannot, Beaujot, Poncelet, Payot.

In his book on Les Français dans l'Ouest Canadien, published in 1959, Frémont (2002) pays particular attention to the priests who founded the parish, and to the French nobles who first came to the district that they called La Rolanderie, but the author does mention four names of people who were neither priests nor nobles: Durand, Lesage, Beaujot and Jeannot. Frémont (2002: 131) writes:

La famille belge François Beaujot, arrivé en 1892, logea dans la Maison blanche, la femme étant la ménagère de l'abbé Nayrolles. Son mari décéda la même année et la mère vécut jusqu'en 1904. Leurs deux fils, Eugène et Lucien ont fait souche à Saint-Hubert.

Translation: The Belgian family of François Beaujot, arriving in 1892, stayed at La Maison blanche, the wife being the cook for Father Nayrolles. Her husband died the same year and the mother lived until 1904. Their two sons, Eugene and Lucien ${ }^{1}$, were born in Saint Hubert. As will be described in Chapter 2, la Maison blanche (also called Bellevue) was originally built by Count Yves de Roffignac whose family had been ennobled since 1248 , and this dwelling later became the rectory for the priests.

La Rolanderie and the parish of St. Hubert receive extensive coverage in Promoters, Planters, and Pioneers: The Course and Context of Belgian Settlement in Western Canada (Jaenen, 2011). This book emphasizes the role of the Catholic Church in forming French-speaking communities, which would have provided a common element across Belgians of Walloon/French and Flemish origins, as well as French from France and Québec. In the section on the community of Saint Hubert, Jaenen (2011: 104-105) notes the families of François Beaujot, Adolph Gatin, Elvire Raiwet, Victor Dumonceaux, Joseph Pirlot, and Justin Havelange from the Namur province of Belgium, plus other Belgian families with the names of Moiny, Poncelet and Payot. This section on Saint Hubert ends with the observation:

The agricultural expertise of the community experienced a tremendous boost with the arrival of two outstanding graduates in agriculture from the University of Louvain - François Smets in 1908 and Paul Mullie in 1911.

\footnotetext{
${ }^{1}$ The author has mistaken the name which should read Eugène and Félicien instead of Eugène and Lucien.
} 
Chapter 3 treats the four families of origin in Belgium and France: Beaujot, Sénéchaud, Mullie, Smets. Then Chapters 4 and 5 treat each of Leon Beaujot and Dorothy Mullie in their own families of origin. The parents of Leon Beaujot and Dorothy Mullie were married the same year, 1910, but in rather different circumstances. Leon's father, Félicien Beaujot, was 13 when he had come to St. Hubert on 27 March 1892 with his parents and four of their seven children. Leon's mother, Bertheline Sénéchaud came to St. Hubert in 1910, on her own at the age of 24. The couple was married in St. Hubert on 14 June 1910. Dorothy's parents, Paul Mullie and Julienne Smets were married on 19 July 1910 in Sint Truiden (Saint Trond), Belgium and arrived in St. Hubert in May 1911, just a month before their first child was born.

Married in the same year, and spending most of their adult lives in St. Hubert, the four parents of Leon and Dorothy had rather different origins. Three are from Belgium and one from France. Of the three from Belgium, one is from the French speaking region, one from the Flemish region, and one from a region that has since switched from Flemish to French.

Félicien Beaujot was born in Malvoisin which is in the province of Namur, Belgium. Namur is at the centre of the Walloon Region of Belgium, or Wallonia, where French is the spoken language. The siblings of Félicien who stayed in Belgium lived at Malvoisin and Patignies (both in the Commune of Gedinne).

Bertheline Sénéchaud was baptized at La Chapelle-Bertrand, near Parthenay in France (District of DeuxSèvres). The family lived in the adjoining Commune of La Peyratte. Other emigrants from the Parthenay region had come to St. Hubert around the turn of the century. In particular, Father Jerôme Boutin was the priest at Saint Hubert as of 1903 and his brother Victor Boutin had come from Pompaire in 1908. The siblings of Bertheline Sénéchaud in France lived in Parthenay, La Peyratte, and Exireuil (near St. Maixent).

Paul Mullie was from Ploegsteert, Belgium. This village is very near the border with France and their farm was essentially in the no-man's-land between the combatants of the First World War. This was originally in West-Flanders, a Flemish speaking region of Belgium, which has since become part of the French speaking Hainaut province. Paul's brother Julien also emigrated to Canada, in 1913. Having to escape the war's frontier, the rest of the family became refugees in Cany Barville, France. Their siblings who stayed in Europe lived in Wijtschate (Belgium), Ploegsteert (Belgium), Warneton (Belgium), Les Loges (Normandie, France), and Foncquevillers (District of Arras, France).

Julienne Smets was from Sint Truiden (Saint Trond in French), province of Limburg, Belgium. This is a Flemish speaking region in the eastern part of Belgium. Julienne had six full-siblings plus three siblings from the first marriage of her father. Of the four families of origin, the Smets family is the only one that was not agricultural, however, Julienne's grandfather was a farmer. Julienne's father was a baker. The brothers and sisters of Julienne lived at Sint Truiden and neighboring areas. Later some lived in Gent, Sint Joost-Ten-Node (Brussels) and Aldenneik (Maasteik). 
As further described in Chapters 4 and 5, Félicien and Bertheline Beaujot and Paul and Julienne Mullie were farm families, but their lives evolved rather differently. Paul had a degree in Agricultural Sciences from the University of Louvain, Belgium, and Julienne had some savings from working in a family-owned grocery store in Sint Truiden. They were able to purchase a farm which was large in the context of Saskatchewan in the 1910s. Within ten years of their marriage, they had expanded their home into a larger dwelling and the last of their five children was born. They were well set to be a successful farm family.

As a bachelor, Félicien had purchased a half-section of land next to his brother's homestead, and he had worked for one of the counts who founded St. Hubert. Bertheline had come to Canada against her parents' wishes, and the long trip had used up her meagre savings. In 1919, the last of their three children was born. Due mostly to health problems, they had difficult lives. In the preface to her 1992 Memories, their eldest daughter wrote:

The first thing that comes into my mind is that I was blessed with wonderful, loving parents, who taught us right from wrong. Something that my dad kept telling us was "Your reputation is worth more than all the money in the world." Perhaps it was a blessing in disguise that we experienced poverty the biggest part of our lives (Driscoll, 1992: 1).

Leon Beaujot first learned English at the Flinton one-room school, district of Handsworth, Saskatchewan. With a teacher who also passed on her love of baseball to her students, Leon also learned how to be successful in a team composed of both boys and girls. His childhood ended at the age of 14 , with the family having to escape the dust bowl conditions of the Handsworth area in the mid-1930s.

With her eldest brother having succumbed to appendicitis, and both her youngest brother and her future husband having been conscripted for military service, Dorothy Mullie became a full-fledged farmer. Her ability to calm horses and other animals, and her passion for finding optimal conditions for grain and garden production, served her for the rest of her life.

Chapter 6 treats the farm lives of Leon and Dorothy Beaujot, from their marriage in 1945 to their $40^{\text {th }}$ anniversary in 1985 . They started with a half section (320 acres) of land. At first it was a mixed farm with household production of most of what was needed for consumption. On the market they sold dry grains but also eggs ${ }^{2}$, cream, pork and beef. Having purchased one of the first weed sprayers of the area, Leon also supplemented the farm income through custom work for other farmers. Especially in winter, when the roads were closed, transportation to church and school was by horse and sleigh or horse and buggy.

In 1959-62, when all but their $9^{\text {th }}$ child were born, they expanded the farm with an additional three quarter-sections of land and moved their home to the land that was more accessible to all-weather roads. The original farm, closer to St. Hubert, came to be called the north farm, while the new home, closer to Langbank, became the south farm. The one-room school at Golden Plain, with a horse-barn in the yard, was closed and the children were now transported by bus to Langbank.

\footnotetext{
${ }^{2}$ In 1948, eggs could be sold to local grocery stores for \$0.34 per dozen, the equivalent of \$4.01 in 2019 dollars.
} 
In this "second wind," the family farm evolved from a labour intensive mixed farm to a business, producing dry grains. By 1968, they were farming what had previously been three farms, with a total of 1120 acres of land ( 1 and $3 / 4$ sections) ${ }^{3}$.

In 1959, a 1947 Model D John Deere tractor was purchased with a loan from the Veterans' Land Act. This was an ideal investment in well-priced durable equipment, taking advantage of young labour. When he spotted a Model D on display at the 2019 Calgary Stampede, Honory reported that he immediately got a taste of dust in his mouth. We also remember other experiences in the fields, like working the summerfallow, and taking a picnic supper out to keep the combine going as long as there was no dew on the swaths. Twice per summer, all contributed to herding the cattle over the 5-mile trek between the north and south farms.

The last chapter is on the retirement years, first on the farm now operated by their sons Norbert and Pat, then to a new home in the town of Kipling, always keeping in touch with family and friends, near and far. Leon and Dorothy especially enjoyed car rides together, checking the crops and recalling their associated experiences. As he rode along with his sons on equipment that was monitored by electronic gages and controlled by a Geographic Positioning System, Leon observed how his back had been affected by having to look both forward, following the row, and back, ensuring that everything was working properly.

With a fifth-wheel camper, they travelled to Alaska, and several times to Florida for the winter. Going to British Columbia in the spring when the flowers were out, and to Ontario for the fall colours, they would visit the families of their children who were not near their home in Kipling. Leon would boast that he did all this driving "without even a scratch on the vehicle". The unfortunate travel memories were in air and water travel: engine failure over the Atlantic forced an emergency landing in Miami on their November 1982 return from Rio, and they had 48 very anxious hours in March 1988 on a cruise ship that had caught fire off the coast of Mexico.

At the ages of 90 and 92 in 2010, they moved to a private care home in Regina, then back to Kipling, and eventually to a private care home in Weyburn. While they were in good care, they were more comfortable seeking out help from family. This brought a new intensity of e-mail exchanges among the children, trying to stay on the same page and wondering how smaller families could manage. As had been their wish, their deaths were close together, on 6 March and 28 May 2014.

On 4 June 2014, the Saint Hubert Church was once again alive. The mass was concelebrated by Reverends Rene Mangahas and Hector Seville who made a point of bringing some Filipino culture into the service. Our hearts were uplifted as the burial became a celebration not only of our parents but of the pioneers who founded the Saint Hubert community.

\footnotetext{
${ }^{3}$ At 320 acres, their original farm was smaller than the average Saskatchewan farm at that time, but by 1968 the 1120 acres made it a third larger than the average Saskatchewan farm of 1971.
} 


\section{Chapter 1 \\ Historical context of European settlement in Western Canada}

The specific community of Saint Hubert needs to be seen in the broader context of the European settlement on the Canadian Prairies. When Saint Hubert was formed in the 1880s, the vast western prairies had already been divided into townships, sections and quarter-sections (160 acres). This division of the land paid almost no attention to the natural geographic boundaries that had guided the previous Indigenous occupants. These new delimitations, and the treaties into which the previous occupants were induced, pushed the Indigenous Peoples into limited areas called reserves.

This way of dividing the land must have seemed very strange to the European settlers. For the Indigenous, it was more than strange, barring them from the way they had previously lived on the territory. The settlers from Europe and Eastern Canada did have some interaction with the Indigenous population. For instance, my Mullie grandparents saw signs of the Indigenous presence through plants and berries that were harvested, especially in the river valleys. In his youth, my Beaujot grandfather was rescued by Indigenous people when he was lost on horseback in a winter storm. He learned to see signs of a coming storm by the behaviour of horses and other animals. A century later, the 1992 Saskatchewan Treaty Land Entitlement Framework Agreement was making it possible for the Cowessess First Nation to acquire 16 quarter sections of land from former inhabitants of the Saint Hubert district (see 2015 Rural Municipality map for Silverwood and 2017 Rural Municipality map for Kingsley).

The European contact with the western prairies had started with the fur trade that produced an EastWest economic system spanning the northern part of North America. This fur trade had started during the period of New France, 1608-1760, and it had continued under British colonial rule. In 1760, the British Crown granted the vast watershed of all rivers and streams flowing into Hudson Bay to the Hudson's Bay Company to promote the fur trade. This area was known by the British as Rupert's Land, named after Prince Rupert of the Rhine (son of King Frederick $V$ of Bohemia) who was the first governor (1670-82) of what became the Hudson's Bay Company.

After the war of 1812 between the United States of America and the British Empire, the Anglo-American Convention of 1818 established the $49^{\text {th }}$ parallel as the Canada-US border in Western Canada. The border had previously been defined by the drainage area of the Hudson's Bay, with all areas draining into the Hudson's Bay being under British rule. While it was not appreciated at the time, this was a significant loss for the area now known as Canada.

In 1869, Rupert's Land was purchased by the Dominion of Canada, making this the largest land purchase in history. The purchase granted one-twentieth of the best farmland in the region to the Hudson's Bay Company (Mooney, 2017a). The region was then called the North-West Territory or simply the NorthWest. The Indigenous and Métis Peoples were not consulted on this purchase which drastically altered their relationship with the land, especially as the Indigenous and Métis were now seen as an obstruction 
to successful agricultural settlement. Seven treaties were signed between the federal government and the Indigenous Peoples in the period 1871-1887.

The provinces that first joined Confederation in 1867 were Quebec (previously Lower Canada), Ontario (Upper Canada), Nova Scotia and New Brunswick. British Columbia joined Confederation in 1871, with the promise of an east-west railroad link, ultimately completed in 1885. The part of the North-West south of the $60^{\text {th }}$ Parallel becoming the provinces of Manitoba in 1870, and Saskatchewan and Alberta in 1905. The part north of the $60^{\text {th }}$ Parallel became known as the Northwest Territory.

Prior to the advent of the railway, trade was conducted along waterways that effectively linked Eastern Canada to the western interior. The economic interests at the time favoured preserving the west of Canada for the livelihood and habitation of Indigenous Peoples, who would trade furs for products from Eastern Canada and Europe. These links between European and Indigenous are also at the origin of the Métis Peoples. Besides their role in the fur trade, the Métis facilitated exchanges between Indigenous and European groups, acting as translators, guides and middlemen, and they themselves were trappers, hunters and agriculturalists (Haggarty, 2013).

At the time of first European contact, the Indigenous Peoples living in the southern plains of present-day Saskatchewan were primarily Nêhiyawak (also known as Cree), with smaller groups of Hohe (also known as Sioux/Assiniboine), Nahkawininiwak (also known as Saulteaux), and OCeti §aúowiñ (also known as Dakota) (Carter, 1990: 25; Saskatchewan Indigenous Cultural Centre, 2021). The Nêhiyawak (also known as Cree) occupied the prairie region from the northern woodlands to the plains, including much of what is now Saskatchewan. The Antler River in the Moose Mountain had the Hohe (also known as Sioux) name of "he-ka-pa-wa-kpa" which the Métis translated as "Tête à la biche" (Deer Head in English) (Léonard, 1987: 9-10). The Pipestone Creek, along which the original St. Hubert settlement was established, had been called the "Calmet" River by the voyageurs and Métis. In their study of traditional land use by the Indigenous Peoples of the White Bear First Nations (now located in the Moose Mountain area, $30 \mathrm{~km}$ south of St. Hubert), Tanner and Tanner $(2015: 80,89,113)$ found evidence of the Pipestone area being used for trapping, fishing and harvesting big game.

Until the 1870s, the Indigenous Peoples had adapted to the food resources of the area, moving camp as necessary, especially to follow the buffalo that grazed in the southern grasslands in summer and wintered in the more protected woodland areas (Carter, 1990: 25-36). They had developed the knowledge and skills to take advantage of the animals and plants of the region, and to adapt to the harsh climate conditions. The horse, acquired in the area around the $1750 \mathrm{~s}$, was also central to hunting, trade and military strategy, and it was important in recreation and social life. Plant food was gathered during the summer, including a wide variety of roots, berries, seeds and fruits which were also dried for winter consumption. The most important plant was the prairie turnip, also known as the white apple or pomme blanche. Besides the buffalo (or bison), several other animals, fish and birds were hunted for 
their protein and fur. Besides their value as food, certain plants and animals were used for medicine, in the exchange of gifts, and in spiritual celebrations (Tanner and Tanner, 2015). Fur was also an important trade resource between the Europeans and Indigenous/Métis, and a mutually beneficial economic system had been established.

However, European contact would bring four major waves of destruction to the Indigenous Peoples of North America (Tanner and Tanner, 2015). The first wave was diseases to which the Indigenous Peoples lacked resistance, with ensuing decimation of populations. Second was the marketization of the subsistence economy with trapping and hunting serving European consumption. The third wave was war, with Indigenous Peoples being brought into conflicts between British and French, then within North America. In the Canadian prairie, there was also the Red River Resistance of 1870 and the North-West Resistance of 1885 . The fourth wave of destruction occurred as the Government of Canada forced the various Indigenous groups onto reserves to allow for European settlement. ${ }^{1}$ Indigenous and Métis Peoples suffered defeats in their attempts to establish permanent agricultural settlements in 1870 in Manitoba and 1885 in Saskatchewan (Boyden, 2013: 54).

The Indigenous groups were effectively removed from access to most resources, especially land (Barry, 2019). Over the period 1871-1887, seven treaties were negotiated between the Government of Canada and various Indigenous Peoples so that European settlement could occur. In the case of the Métis, after the resistances of the 1970s and 1880s, the original inhabitants were dispossessed of their land through a system of Métis scrip (Robinson and Filice, 2019). A scrip is a document, certificate or voucher which grants the bearer certain rights. As of 1870, the Government of Canada devised a system of Métis scrip whereby the Métis were given scrips redeemable for land or money, in exchange for their original land rights. The system was poorly organized and subject to fraud, such that, in most instances, the Métis never did acquire the land that had been promised. ${ }^{2}$

After 1850, the livelihood of the Indigenous Peoples of the prairie region was undermined by the growing scarcity of the buffalo (Carter, 1990: 35). As of the mid-1880s the buffalo had been effectively eliminated from the Great Plains of North America (Foster, 2015). Bison, or buffalo, had been the primary food resource, with an estimated 30 million animals before European contact. The

\footnotetext{
${ }^{1}$ As an example, in the late 1870s, many Indigenous groups had relocated to the Cypress Hills where buffalo were still available. Indian Commissioner Edgar Dewdney also promised food rations that would be delivered out of Fort Walsh (Innes, 2018). In the summer of 1881, Dewdney became concerned with the concentration of Indigenous population in the Cypress Hills and imposed conditions that certain groups had to relocate in order to have access to food rations. One of these groups was the Cowessess band who, in 1882, relocated at Crooked Lake area of the Qu'Appelle Valley, $55 \mathrm{~km}$ northwest of St. Hubert. The Cowessess First Nation has since estimated that this relocation led to 320 deaths, or a third of band members (as cited in Innes, 2018).

${ }^{2}$ After the Red River Resistance, the Manitoba Act of 1870 essentially established a Métis province, with some $1,400,000$ acres of land being set aside for the Métis. However, the Métis were not able to acquire their land rights until proper surveying of the land was performed. Due to poor administration and fraud, "as little as 15 per cent of the original 1.4 million acres promised under the Act were ever distributed" (Rea and Scott, 2017). Many Métis migrated further west, especially to the area of Batoche along the South Saskatchewan River, where the NorthWest Resistance would take place in 1885.
} 
transcontinental railways presented barriers to bison migration, creating Texas gates across the continent. The use of horses and breech-loading rifles for hunting, as well as the increased industrial value of bison products, all contributed to the collapse and near extinction of the bison population, to a level of around 100 animals by the late 1890s.

\section{European settlement}

The period surrounding Canada's Confederation in 1867 was a time of depression in international trade, with reduced markets for Canadian staple products, fur in particular. The Government of Canada sought to consolidate its hold on the western regions by promoting railroad links and settlement. The 1868 Free Grants and Homestead Act sought to increase immigration, especially to the west. The 1872 Dominion Lands Act outlined provisions for granting homesteads to settlers. Homesteads of 160 acres were available at the cost of $\$ 10.00$, under the conditions that the owner would clear ten acres of land and build a residence within three years (Mooney, 2017b).

In April 1871, the Government of Canada decided to use the grid system to subdivide the land available for settlement (Waiser, 2007: 156-157). This explicitly rejected the river-lot system that had been used by the French along the Saint Lawrence River in Quebec. This system of narrow plots of land upward from river transportation was also used by the Métis and Indigenous Peoples along the Red and Assiniboine rivers of present-day Manitoba, and along South Saskatchewan River south of Prince Albert. Instead, the grid system divided all the land into townships (36 square miles), sections (one square mile) and quarter-sections (160 acres).

A "homestead" as defined by the Grants and Homestead Act consisted of a quarter-section. By the end of 1887, 70 million acres had been measured (over 400,000 quarter-sections). Not all land was to be used as homesteads. Of the 36 sections in each township, 16 sections were designated as railway land to help pay for railway construction, $13 / 4$ sections were for the Hudson's Bay Company that had sold Rupert's Land to the Government of Canada, and two sections were designated as school lands to finance the school system. Depending on the situation, some of the land was designated for "Dominion Lands Sales" and other areas were drainage and swamp lands or irrigation lands (Tyman, 1971). This task of surveying the land for settlement was done quickly, without the support of land or climate surveys which would have prohibited homesteads in areas unsuited for cultivation. As a consequence, some four in ten homesteaders did not stay long enough to secure their title (Fawke, 1957: 285).

The National Policy adopted in 1879, sought to further develop the East-West integration by promoting settlement in Western Canada as a market and source of raw materials for an industrial base in Central Canada (Fowke, 1957). By 1883, the railway link between Winnipeg and Calgary was operational, and in 1885 the line was open to Vancouver.

The land was no longer valued for the harvesting of wild animals and native plants, but for the agricultural production of grain and domestic animals. The government actively promoted Western settlement by people of European origins, including through subsidies to the railroads and transatlantic 
shipping lines. In contrast, there was very little encouragement of settled agriculture by Indigenous and Métis. Treaties 4 and 6 did include government support for agricultural implements and agricultural instruction. However, these provisions were poorly implemented and largely not successful in supporting Indigenous agriculture (Carter, 2020). In her book on Lost Harvests: Prairie Indian Reserve Farmers and Government Policies, Sarah Carter (1990: ix) finds that, in the decade after 1885, "government policies made it virtually impossible for reserve agriculture to succeed because the farmers were prevented from using the technology required for agricultural activity in the West". Then after the turn of the century, much reserve land was surrendered.

With wheat replacing fur as the main staple output from the prairie region, it was necessary to develop a variety of wheat that could mature in the short prairie growing season of about 90 days. The federal government took an active role through experimental farms. The Central Experimental Farm in Ottawa began developing wheat crossings on 19 July 1888. The Marquis variety was discovered in 1904 (Coneghan, 2017) ${ }^{3}$. In 1907 a full-scale field trial was done at the Indian Head Experimental Farm. It was then sent to the Experimental Farm in Brandon, and the distribution of the new variety began in the spring of 1909. Four hundred samples were sent to farmers throughout Western Canada, but this does not seem to have included Indigenous reserves (Government of Canada, 2017).

Besides government, various other organizations became involved in Western settlement: the Hudson's Bay Company, religious organizations, commercial companies seeking to make a profit by reselling the cheaply available land, and persons with extensive capital who set up large scale agricultural enterprises (Lapointe and Tessier, 1988: 56). As seen in the next chapter, these private agricultural enterprises included La Rolanderie Farming and Stock Raising Company based at Saint Hubert, and the Qu'Appelle Valley Farming Company based at Indian Head.

\section{Immigration and ethnic composition of the population}

While the period 1861-1896 had been a long period of net emigration from Canada, partly to the advantage of the faster industrializing New England states and the agricultural advantages of the American Western Plaines, the period 1897-1913 became a period of particularly high immigration to Canada. The numbers of immigrants climbed from 17,000 in 1896 to over 400,000 in 1913 (Kerr and Beaujot, 2016: 101).

The population of Saskatchewan increased from 41,522 people in 1891, to 91,279 in 1901 . With this large population growth, the Government of Canada instituted a mid-decade census in 1906 to cover the three Prairie Provinces. This 1906 Census determined that the population of Saskatchewan had

\footnotetext{
${ }^{3}$ Marquis was a crossing with Red Fife, originally from Galicia in Eastern Europe, now part of Ukraine and Poland (Government of Canada, 2017).
} 


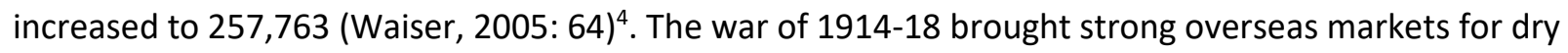
grains produced on the Canadian Prairie. By 1921, Saskatchewan became the $3^{\text {rd }}$ province in population $(757,500)$, after Ontario $(2,933,700)$ and Quebec $(2,360,500)^{5}$.

In contrast to the population of the Atlantic Provinces and Central Canada, the West of Canada was more diverse with more than half of origins that were neither English nor French. It had been the objective of Clifford Sifton, who was Minister of the Interior and responsible for immigration in the period 1896-1905, to create a distinct region in the former North-West that would not be caught up in the English/French and Protestant/Catholic compromises of Central Canada (Hall, 2007: 96). By bringing people from a variety of origins, but with those of British origins being the largest group, Sifton hoped to establish a distinctly Western society, with assimilation towards British values (idem, 80).

Given this variety or origins, there was a natural tendency for people of the same origin to settle in given locations. In Settling Saskatchewan, Alan Anderson uses the concept of "block settlements" to emphasize the formation of communities based on people of the same ethnic origin. This book counts a total of 32 French settlements in Saskatchewan, with a dominance of the population arriving directly from Western Europe: France and Belgium, and to a minor extent Luxemburg and Switzerland (Anderson, 2013: 286).

While Anderson does not have a separate chapter on the block settlements of Belgian origins, he does note the presence of Belgians in several communities including Saint Hubert where they were more numerous than those of French origin. In 1911, the Belgian government established a consular office in Forget, which was later transferred to Manor in 1915, closing in 1921 (Anderson, 2013: 272). The town of Forget was named after Amédée Forget, who was the last Lieutenant Governor of the North-West Territories (1898-1905), then the first Lieutenant Governor of Saskatchewan (1905-1910). The towns of Forget and Manor are in Southeastern Saskatchewan, at distances of 70 to $80 \mathrm{~km}$ from Saint Hubert. While the population of Saskatchewan grew rapidly in the period 1891 to 1911, those with origins in Quebec, France or Belgium remained relatively small. At the 1911 census, the Saskatchewan population included 96,206 people born in Ontario but 12,969 born in Quebec (Census of Canada 1911: Vol II, Table XXIII). In the foreign-born population of Saskatchewan in 1911, there were 2,940 from France and 1,271 from Belgium, thus these were $13^{\text {th }}$ and $15^{\text {th }}$ in magnitude among the 18 specific places of origin listed in the 1911 Census $^{6}$ (Census of Canada, 1911: Vol II, Table XVII).

\footnotetext{
${ }^{4}$ These figures include the Indigenous population, but the First Nations' population was seriously undercounted. The Indigenous population of Saskatchewan was counted at 6,358 in the 1906 Census, or $3 \%$ of the total, down from 8\% at the 1901 Census (Waiser, 2005: 64).

${ }^{5}$ The 2016 Census established the population of Saskatchewan at 1,098,352, making it $6^{\text {th }}$ among the Canadian provinces, or the smallest, by population, west of the Atlantic Provinces.

${ }^{6}$ According to the 1911 Census, half of the population of Saskatchewan was foreign born, with a third of the foreign-born being from the British Isles. Among those not born in Canada, the largest number were from the United States of America, followed by England, then Russia, Scotland, Austria, Poland, Germany, Norway, Romania, Sweden, Hungary, Ireland, France, Iceland, Belgium, Wales, Denmark and Italy (Census of Canada 1911: Vol II, Table XVII; Lapointe and Tessier, 1986: 99).
} 
A number of factors contributed to the relatively small French-origin population in the Prairie Provinces. France had been earlier in undergoing a demographic transition toward lower fertility and did not have the surplus population to enable the level of British movement out of Europe to the British Empire. Even within Canada, the preference in the Catholic elite of Quebec was to have people stay in Quebec or move to closer locations in Ontario or New England, rather than to go to the West of Canada (Silver, 1969). The treatment of the Métis, after the Red River Resistance of 1869-70 and the North-West Resistance of 1885, also discouraged French Canadian movement to the West.

At the 1971 Census, there were 56,200 people of French origin and 3,555 people of Belgian origins in Saskatchewan, representing respectively 6.1 and $0.4 \%$ of the population (1971 Census of Canada, Vol 2.1: Table 2). At the 2016 Census, only $1.3 \%$ of the population of Saskatchewan had French as their first official language spoken, with 1.6\% having French as their mother tongue, $4.8 \%$ knowing French enough to carry on a conversation, but $0.5 \%$ declaring French as the language most often spoken at home (Statistics Canada, 2017, 2019).

Several factors contributed to the limited presence of French in Saskatchewan, in spite of the country having been originally based on an English-French dualism (Smith, 2010; Beaujot and McQuillan, 1982). Canada was increasingly defined in terms of diversity and pluralism. For instance, the Royal Commission on Bilingualism and Biculturalism, 1963-69, used the concept of multiculturalism rather than biculturalism, entitling its $4^{\text {th }}$ volume: The Cultural Contribution of the Other Ethnic Groups.

It was not until after the Official Languages Act of 1969 that educational opportunities were expanded for official language minorities. By then it was clearly too late for communities like Saint Hubert, where education as of the early 1910s was mostly in English. Already in the 1930s, young people in Saint Hubert were speaking in English among themselves, even though they spoke in French with their parents and grandparents. With the church being the only institution operating in French, the value of French education was not clear to students and their parents. The larger forces of urbanization came to undermine the future potential of an isolated French-speaking community ${ }^{7}$. With fewer people living in rural areas, some communities were destined to disappear due to various factors including their size, their placement vis-à-vis transportation, and the distances to other communities that were better placed to survive.

\footnotetext{
${ }^{7}$ There were other communities in the area that had significant French populations, but these were some distance away given the available means of transportation: Dumas, Wauchope, Redvers, Manor and Bellegarde to the southeast, and Forget and Montmartre to the west.
} 


\section{Chapter 2 \\ Saint Hubert, Saskatchewan}

When the Catholic parish of Saint Hubert closed after its $100^{\text {th }}$ anniversary in 1990 , the remaining signs of Saint Hubert are a church with a new roof and seating capacity for 200 people, a stone cairn erected in 1940 on the hills of the Pipestone Creek where the old stone church stood until 1903, and two cemeteries, one near the church and one near the stone cairn. In 2017 there were 17 farm families, some 50 people, living in the former district of Saint Hubert that once numbered over 300 people plus a nursing home with 100 patients and 30 staff.

At the time of European settlement, the district was originally called La Rolanderie, by a group collectively known as "French counts" who settled along the Pipestone Valley in the mid-1880s. With the establishment of a French-Catholic parish, it became "Saint Hubert," the name given to the parish. The post office, which opened in 1915 and operated until 1968, was given the name "Saint Hubert Mission, Saskatchewan" in order not to be confused with the "Saint Hubert, Quebec" on the south shore of the Saint Lawrence, close to Montreal (Sullivan, 2009: 68).

By the early 1900s, Saint Hubert had become a vibrant rural community. Besides the church and rectory, there would eventually be a hamlet with 14 homes, along with a school, general store, credit union, garage, electricity generating plant, curling and skating rink, and a nursing home with as many as 100 occupants. While small, it was a full community, with activities for persons of all ages including ball teams, church picnics, fall suppers and even silent movies and talkies shown in the church basement on Sunday evenings.

The Saint Hubert Church is $72 \mathrm{~km}$ west of the border with Manitoba, and $140 \mathrm{~km}$ north of the border with the United States. Within Canada, Saint Hubert is 3,900 km from Halifax on the Atlantic coast and $1,900 \mathrm{~km}$ from Vancouver on the Pacific.

Whitewood is the closest town, $8 \mathrm{~km}$ east across the Pipestone Valley then $12.5 \mathrm{~km}$ north along Highway \#9. Whitewood is located on the Canadian Pacific Railway and the Trans-Canada Highway, between Winnipeg and Regina. The rail line to Whitewood opened in 1882, allowing for settlement of the surrounding area. Whitewood is also 2,900 km west of Quebec City, which was then the most western port of debarkation for trans-Atlantic ships.

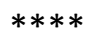

Geographically, Saint Hubert is in the ecoregion of southern Saskatchewan called Aspen Parkland (Padbury and Acton, 1999: 160-162). The Saint Hubert area is not as flat as many parts of Southern Saskatchewan. The glaciers left hills and plains with various creeks and streams. This made for an area that was well suited to "mixed farming" in animals and grain at the time of settlement. There was water 
from the creeks and beaver dams for the horses and cattle, along with flat plains that could be cultivated. Sometimes the creeks and streams were difficult to cross, but the one east of the Mullie farm toward St. Hubert had a bridge for as long as can be remembered.

Each family had a garden, and there was potential to hunt for deer, ducks and prairie chickens, and to gather wild berries, especially raspberries and saskatoons. In the gardens, the most common vegetables were potatoes, carrots, cabbage, beans, peas, lettuce, radish, cucumber, tomatoes, turnip and onion, along with raspberries and gooseberries.

The railroads passed through Whitewood to the north and Inchkeith, Langbank and Kennedy to the south, making a considerable distance to bring produce to market. For several months of the winter, the roads were not open to vehicular traffic even into the 1950s, and transportation needed to be by horse and sleigh in winter or horse and wagon when the roads were wet and muddy in spring or after a rain.

The weather could also be harsh. At the Moosomin weather station, which is $55 \mathrm{~km}$ from Saint Hubert, the average daily minimum temperature is below zero for October to April, and the average daily maximum is below zero for November to March (El Dorado Weather, 2017). On average there are 113.8 days with maximum temperatures below freezing, with mean temperatures of -16.1 degrees Celsius in January and 18.6 degrees in July, for a yearly average daily temperature of 2.6 degrees (El Dorado Weather, 2017). There is an average of $392.1 \mathrm{~mm}$ of rainfall and $119.3 \mathrm{~cm}$ of snowfall. ${ }^{1}$

These statistics do not completely render the challenge posed by the climate of the area. The Indigenous population would not remain on the open prairie in winter, instead following the buffalo to woodland areas that offered more protection from blizzards, along with firewood and the availability of water.

Sylvain Dumonceaux, whose grandparents had come to Saint Hubert in 1892, recalls the story of his sister Monique who was struck with appendicitis in mid-winter of 1947. Their father went to the neighbors to use their telephone and consult with the doctor. The air ambulance could not come out under these conditions and the doctor proposed that they would call back in a day or two while waiting out the storm. The blizzard lasted a whole week and thus four days later parents and child left for Whitewood in a closed-in cutter, with neighbors along the route "making tracks" that the horses could follow, taking 9 hours to travel the $25 \mathrm{~km}$ distance. The story ended well with the lone doctor making a successful operation into the night.

Possibly in that same storm, a train got stuck in the snow some $15 \mathrm{~km}$ out of Moose Jaw, on its way to Weyburn. Contacting their home base to determine what to do, the crew was told to drain the boiler, abandon the train, and find their way back to their point of departure, instead of expecting others to come to their rescue.

\footnotetext{
${ }^{1}$ In comparison, Paris has an average of 29 days with temperatures below freezing, and average temperatures of 5 degrees Celsius in January and 20 degrees in July, with an average annual precipitation of $641 \mathrm{~mm}$ (Discover France, 2017).
} 
Snowstorms could arrive as early as October. When Jeanette, the youngest child of Leon and Dorothy, was married shortly after Thanksgiving, on 27 October 1984, a sudden snowstorm required that Sylvain Dumonceaux come with a snow plough to clear the road so that the family could make it to the wedding in Saint Hubert.

\section{La Rolanderie}

In spite of the few remaining signs of the previous community, Saint Hubert occupies two pages of Alan Anderson's (2013: 268-70) Settling Saskatchewan, and a whole chapter in Donatien Frémond's (1959) Les Français de l'Ouest Canadien. All accounts start with La Rolanderie, the name given by members of the French nobility who came to the area in 1885-1892. There is also an extensive Wikipedia (2017) entry entitled "The French Counts of St. Hubert, Saskatchewan."

The first person to arrive was Rudolf Meyer, an investor and settlement agent. The first count to arrive was Yves de Roffignac whose family had been ennobled since 1248 (Léonard, 1987: 182, as cited in Sullivan, 2009: 45).

While there remains uncertainty regarding the exact numbers, the careful reconstruction of Kris Sullivan (2009: 43, 49) lists 20 men, 7 spouses and some 15 children. Sullivan refers to them as twelve wealthy gentlemen and their families, plus other artisans, gardeners or helpers who accompanied the counts and men of wealth. Jaenen (2011: 102) establishes the numbers as eight counts, two viscounts plus a Belgian baron and his brother. Anderson (2013: 268) indicates that on his departure Meyer sold his holding to 11 French and Belgian aristocrats, while Smeets (1980: 3) refers to 14 plutocrats: nine French counts, one Belgian baron and his brother, and three men of capital.

In his Saskatchewan: A New History, Bill Waiser (2005: 62-63) writes of La Rolanderie as "a haven for French aristocracy on Pipestone Creek just south of Whitewood [where] at least thirteen counts headed into the wilds of southeastern Saskatchewan to recreate their sophisticated lifestyle, complete with servants, impressive homes, and extravagant parties." Waiser continues:

Suddenly the area could boast more nobility than any other place in North America. But the counts' local business activities, which included a cheese factory and sugar beet plantation, failed because of arrogance and overconfidence. By 1900, most had returned to France, leaving behind their hired help who had decided to stay after their employers had given up.

The community has been classified as an "utopian settlement," seeking to start an ideal agrarian community in the prairies of North America (see Rasporich, 2007: 139-140 in The Prairie West as Promised Land). However, by 1904, this group, collectively known as the "counts of Saint Hubert," had left the area, having attempted various enterprises from cheese, chicory and sugar beet production, to raising horses, cattle, sheep and hogs. Cornelius Jaenen (2011: 104) ends his colourful account by saying: "The aristocrats left, poorer if not wiser, and their utopian vision faded in the blizzards and prairie fires." 
In Memories of St. Hubert 1980, Edmond Dunand (1980: 217), whose father François Dunant arrived in Saint Hubert in 1891, gives the following account:

These rich gentlemen of title ... did not succeed in their ventures. They had theory but no practical experience. They tried to manufacture cheese but did not test the land and grasses. ${ }^{2}$ Being there's much alkali in our lands, the cheese would not cure and age. Instead it bloated to the point of causing damage to the sheds and was not sellable. Chicory was grown to make a coffee blend, but they put in too much. ... Raising pigs for bacon didn't succeed. ... It was a poor market - approximately ten to twelve miles by horse transportation to the railway in Whitewood, then to the market area in Winnipeg.

A little incident happened one day when François Dunant was foreman of a band of Indians hired to dig the chicory. They were working in the field of chicory when the Count came to watch them. He was in full dress - leggings, white pants, red jacket with swallow tails, and a tall black hat, along with his light walking stick and gloves. When the Indians saw him in that attire, they all looked up, stopping work for a good look at him.

At the end of the day, the foreman was called to the office to give account of the day's work. The Count said, "When I was there this afternoon, no one was working. They all had their heads up." The foreman's reply: "When they saw the attire like you had on, anybody would look up."

The documentation of the historical record on La Rolanderie includes various contemporary newspaper articles, letters exchanged with government authorities and three Orders in Council from the Government of Canada.

In his thesis on The French Counts of St. Hubert: An Archaeological Exploration of Social Identity, Sullivan (2009: 270-271) includes an appendix listing the known pertinent newspaper accounts of Saint Hubert. The earliest item is from the Regina Leader dated 26 May, 1885 entitled "Arrival of Meyer and Hauswirth." Rudolf Meyer had come to visit the area in 1881 and he is widely accredited to have been the founder of the community, symbolized by the fact that his home and property on SE 4-15-3 were called La Rolanderie, after the name of the $18^{\text {th }}$ century chateau of M. Lorin, his French benefactor from Maule, Seine-et-Oise, now part of Ile-de-France which includes Paris, France (Sullivan, 2009: 37). Over the period 1890-1892, there were 16 other articles on topics such as "Chicory enterprise of Brabant and Roffignac", "Sugar beets discussed at public meeting", "Rolanderie Stock Raising Society" and "Richelieu French Coffee Manufacturing Company" in The Colonist (Winnipeg), Le Manitoba, Manitoba Free Press, Ottawa Citizen and Regina Leader. Three titles from the Regina Leader of March to June 1892 can be seen as representing the demise of these enterprises: "Coffee mill sold", "French farmers to settle," and

\footnotetext{
${ }^{2}$ Edmond's father, François Dunant, had arrived in Saint Hubert in April 1891, from Sonjieu, France, to help with making cheese. However, he had advised that the high alkali content of the grass would not produce milk of the proper quality for cheese. The counts did not believe him, but it turned out that he was right.
} 
"Chicory factory destroyed by fire," while another indicates the continued viability of the community through the title "French immigrants arrive."

Another important newspaper entry is simply called "La Rolanderie" on the first page of the very first issue of the Whitewood Herald (3 March 1893). John Hawkes, who was editor of the Whitewood Herald from 1897 to 1900 and later become the first Legislative Librarian of Saskatchewan, included a chapter on "The romance of the French Counts at Whitewood, Assiniboia" in his three volume The Story of Saskatchewan and Its People (Hawkes, 1924: 937-942).

Much of the early history was first recorded by Father Benjamin Fallourd, priest in the Saint Hubert Parish from 1904 until his death in 1949. Based on letters and memories, Father Fallourd wrote a series of articles in the Whitewood Herald and in La Liberté et le Patriote (Winnipeg) in the period 1940-42.

Then in 1954, A.E.M. Hewlett (1954) wrote an article in The Beaver: Magazine of the North, published by the Hudson's Bay Company, on "France on the Prairies", and three articles in the Regina Leader-Post entitled "History of the Counts." There was another article in The Beaver in 1978 entitled "Dr Rudolf Meyer and the French Nobility of Assiniboia" (Humphrys, 1978). Assiniboia was the name of the district of the North-West Territories that became the southern part of Saskatchewan in 1905.

One of the earliest extensive treatment in a book form is that of Donatien Frémont, who had been editor of La Liberté in 1923-41. Frémont included a chapter on La Rolanderie and the early history of the parish of Saint Hubert in his Les Français dans l'Ouest Canadien, published in 1959 and reissued posthumously as a second edition in 1980 and as a third edition in 2002 (Frémont, 2002). The article by Michelle Guitard (1977) in Saskatchewan History was probably the first substantial treatment in an academic journal.

As a graduate student in history, Larry Smeets (1980: 3-8) was called upon to write an account in the community book Memories of St. Hubert 1980, that he entitled "The 'French Counts' and the origins of St. Hubert." Smeets treats the "adverse social, economic, and political changes that were threatening to undermine" the life of the old French nobility since the French Revolution, especially after the FrancoPrussian war of 1870, the founding of the Third Republic in 1870, and the Commune of 1871. After discussing the various reasons for the counts' lack of business success, including their inability to get government approval for sugar beet production because of its alcoholic by-product, Smeets nonetheless observes that this founding group was not only adventuresome but also innovative and experimental in looking for agricultural ventures suitable for the Saskatchewan prairies.

Since 1980, there have been two substantive studies of the historical record, and a number of smaller accounts have been published. On behalf of the Association culturelle franco-canadienne de la Saskatchewan (now called ACF or Assemblée communautaire fransaskoise), Carol Léonard (1987) made a case for establishing an historical park at Saint Hubert. His report, entitled La Rolanderie: Rapport sommaire d'une recherche sur les débuts de Saint-Hubert en Saskatchewan et sur son aristocratie locale, has a main texte of 195 pages, plus 198 pages of appendices. 
Léonard divides this history into two parts: "Rudolf Meyer's Rolanderie" of 1885 to 1889 and "La Rolanderie of the Aristocrats" of 1889 to 1899 . This emphasizes the founding role of Rudolf Hermann Meyer who was an economist with strong interests in "Social Catholicism" as a means of alleviating the human costs of industrial capitalism. Of Swiss or German origin, he would have sought collaboration with members of the French aristocracy to attempt an experiment in agrarian development based on small property owners. He wrote various books including a treatise on the political history of small properties in an agricultural setting (Meyer and Ardant, 1887). He would also have been associated with Pope Leo XIII whose 1891 encyclical Rerum Novarum (On the Condition of the Working Class) made a case for social and Catholic ideals, as an alternative to liberal and socialist approaches for alleviating the ravages of industrialization (Léonard, 1987: 59; Moon, 1921: 159). As with other reform movements of this period, there was particular concern with the capitalist treatment of labour as a commodity whose price was determined by supply and demand.

Meyer was also very astute in obtaining government support. He managed to get three Orders in Council issued in support of his business and settlement projects. These were signed by John J. McGee, Clerk of the Privy Council, as approved by His Excellency the Governor General in Council (Ref.88,847 dated 11 May 1885, Ref.95,559 dated 10 September 1885 and Ref.116,762 dated 26 May 1886; see Léonard, 1987: Annexe 1: 1-14). The first of these Orders refers to Meyer's "project for Swiss settlement in the North-West ... and a list of names of settlers, comprising two hundred families, having sufficient means to enable them to begin farming .... ." The document goes on to promise land for Meyer and for the settlers under the conditions of the Dominion Lands Act. The document then establishes the "condition that the settlement shall have been commenced and that they shall have erected ... on or before the $30^{\text {th }}$ day of November, 1887, a building in which to carry on the manufacture of cheese, and the requisite machinery to prosecute that industry, ... to cost not less than three thousand dollars ... ."

The third Order in Council, dated 26 May 1886, refers specifically to "a Swiss and German Immigration colonization project at Whitewood, in the Provisional District of Assiniboia." It refers to delays and high prices of construction due to "disturbances in the North-West" and "the destruction of hay in the neighborhood of his colony by prairie fires." The disturbances would be those of the 1884-1885 NorthWest Resistance, with the final battle at Batoche, Saskatchewan. There is reference to Meyer having "already spent nearly six thousand dollars" [\$120,000 in 2017]. The document also specifies that "Dr. Meyer has furnished proofs of the adhesion of one hundred and seventy-five Swiss families to the project, who actually sailed, taking the route via New York by one of the direct European lines to that port." The same 1885 "disturbances" would have brought the colonists to stay in the United States, thus "Dr. Meyer proceeded to Europe during last winter at his own expense, for the further promotion of immigration to the colony." The document concludes that, due also to Meyer's considerable expenses which "have been of substantial value to the cause of immigration to Canada from the continent of Europe" ... "the conditions in the extract, recited, should be held to have been substantially complied with." 
Dr. Rudolf Meyer also sought to set up an experimental farm at the location of his settlement. In November 1886, he organized a visit to La Rodanderie by Professor William Saunders ${ }^{3}$, Director of Experimental Farms (Sullivan, 2009: 40). Saunders subsequently turned down the proposition, in favour of establishing an experimental farm at Indian Head. This Dominion Experimental Farm at Indian Head used part of the property of the Qu'Appelle Valley Farming Company, also known as the Bell Farm from the name of its general manager, Major William R. Bell. In 1885, the horses from the Bell Farm were commandeered to put down the North-West Resistance at Fish Creek and Batoche (Briere, 2009). Since the horses were not available for the farm work, the land was left fallow in 1885. A good crop was produced the following year since more moisture had accumulated. The Experimental Farm took advantage of this experience, with research on "fallowing the land" or summerfallow (McClinton, 2017; Johnson and Smith, 1986). Only later was it discovered that this practice reduced soil quality and was not sustainable. Alternative farming systems were developed in the 1970s. In particular, direct seeding allowed for more of the moisture from snowfall to be trapped for the following year's crop.

With Meyer's departure in 1889, Léonard (1987) proposes that the remaining nobles were more interested in business profits than in experimentation and social reform. In 1889, Meyer sold his holding of 4,480 acres (18 quarters in Townships 14 and 15) to eleven French and Belgian nobles (Smeets, 1980: 4; Anderson, 2013: 268). The company was called the Rolanderie Farming and Stock Raising Company, under the leadership of Marie Martial Yves de Roffignac. This company coordinated the capital accumulation and used labour resources either from France and Belgium or from persons already in the community. For instance, farmers were supplied with seeds for growing chicory and sugar beets.

Besides the Carol Léonard (1987) report, the history of the French counts has been extensively summarized in Kristian Sullivan's M.A thesis at the Department of Anthropology and Archaeology, University of Saskatchewan: The French Counts of St. Hubert: An archaeological exploration of social identity (Sullivan, 2009). The main focus of the thesis uses over 3000 artifacts from a 2006 excavation of the Bellevue site to investigate the social identity of the counts. Sullivan's 60-page chapter on "The History of the French Counts" presents a well-integrated and documented account that merits separate publication (idem, pp. 8-68). Bellevue was the name given by Yves de Roffignac to his home built circa 1889 on NW 3-15-3-W2M.

Roffignac had come from the Département de Haute Vienne in France in 1886, at the young age of 21 years, and stayed at La Rolanderie for about six years. After living with Meyer at the La Rolanderie residence itself from 1886 to 1889 , Roffignac built his own residence that he named Bellevue (Sullivan, 2009: 49). In 1890, he married Germaine Marie Louise Isabelle de Salvaing de Boissieu, daughter of a wealthy industrialist. With Baron van Brabant, Count de Roffignac established the Bellevue French Coffee Company using locally grown chicory as a flavour (Anderson, 2013: 269). After Meyer's departure in 1889, Roffignac became the Director of the Rolanderie Farming and Stock Raising Company. Roffignac left the area in about 1892 for Long Island, New York and eventually lived in Cherchell, Algeria, where

\footnotetext{
${ }^{3}$ It was Charles Saunders, the son of William Saunders, who discovered the Marquis Wheat in 1904 (Coneghan, 2017).
} 
he died in 1943 (Sullivan, 2009: 43; Léonard, 1987: Annexe 7, p. 17). After Roffignac's departure, Bellevue was used for short periods as a residence by other counts, then as the church rectory until 1904, when it was moved to Alexandre Jeannot's property (Sullivan, 2009: 66, 162-163).

While much shorter than Léonard's (1987) report and Sullivan's (2009) thesis, several other accounts have been published. In Our Towns: Saskatchewan Communities from Abbey to Zenon Park, David McLennon (2008: 441) writes about the "group of titled French and Belgian nobility" who "left a wellendowed parish of St. Hubert" where "the descendants of their servants and workers would maintain a unique, French-speaking presence in the area." In their book on the history of Francophones of Saskatchewan, Lapointe and Tessier (1988: 62-63) use the Saint Hubert settlement as an example of individuals with extensive capital setting up large scale agricultural enterprises on the prairies. Cornelius Jaenen (2011: 102-105) treats La Rolanderie as the first entry under "utopian settlements" in his book on Belgian settlement in Western Canada. In his book on In Back to the Past: Celebrating Saskatchewan's People and Places, Paul Spasoff (2005: 76-79) entitle his chapter: "Counts write colourful and classy chapter to Whitewood and area history." In Westworld, the magazine of the Canadian Automobile Association, Dave Yanko (2012: 12-16) uses the title: "Yves de Roffignac was here: The short history and lasting legacy of St. Hubert's top-hatted French counts."

There are also two articles in Revue historique, available at the Musée Virtuel Francophone de la Saskatchewan: "Au pays des comtes" (Léonard, 1999) and "La Rolanderie revivra-t-elle?" (Dubé, 1999). The Musée Virtuel Francophone de la Saskatchewan (2017a, 2017b) also has entries on "Saint-Hubert" and "Noblesse et prairie." Lavergne-Smith (2016) has a verbal description entitled "Sur la trace des comptes à Whitewood," associated with a transmission on Ici Radio-Canada. As indicated earlier, the Wikipedia (2017) entry is entitled "The French Counts of St. Hubert, Saskatchewan." There are short accounts in The Canadian Encyclopedia on "St Hubert Mission" (Pugh, 2006), and in The Encyclopedia of Saskatchewan on "French Settlements" (Anderson, 2017) and on "Whitewood" (McLennan, 2017).

It is worth quoting from Saskatchewan, a book by Edward McCourt written for tourists interested in history. After three pages on Cannington Manor, an English settlement (founded in 1882 and deserted in 1905), McCourt (1968: 31) observes in a much smaller entry:

The only other settlement in the Saskatchewan country to match Cannington Manor in terms of blood, money, and whoopee was that of the French Counts centering on the village of St. Hubert a few miles north of Moose Mountain and not more than a day's ride from Cannington. The Frenchmen were authentic aristocrats whose dreams far out soared their capabilities and capital, but while they lasted, they outshone even the Cannington Manor crowd in colour and éclat. The Counts ran large herds of cattle and sheep and horses along the Pipestone Valley; ... they imported from the old land, not sports equipment or foxhounds, but vintage wines and, for their ladies, Paris gowns. [They] held court once a year in the Whitewood Hotel, and, in contrast to the more exclusive Cannington Manor hosts, invited all the world to share the frolic and the wine. 
As several commentators have observed, some of the agricultural projects of French counts were lacking in realism and business acumen. Their expensive lifestyle may have interfered with their economic success. They were also unlucky, with a fire destroying the cheese factory and the government's refusal to permit the refining of sugar-beets because of the alcoholic by-product. There were many unknowns, including the growth in demand for chicory and other products. In contrast to Cannington Manor which was mostly a setting for maintaining an upper-class lifestyle, the counts and investors of La Rolanderie had serious business intentions. They would not be the only ones to have failed in establishing themselves in a developing frontier. In effect, La Rolanderie lasted longer than the 53,000 acre Bell Farm at Indian Head which only operated from 1882 to 1889 (Briere, 2009).

The lasting legacy of La Rolanderie is the parish and community of Saint Hubert. At the departure of the counts, those left behind operated smaller holdings that could be managed by a farm family, with help from neighbors especially at harvest time and for building homes, barns and other structures. The similarities in social standing across small farmers, along with the French Catholic ${ }^{4}$ culture, became basis for community and assistance across families.

As of their arrival in Saint Hubert in May 1892, the Beaujot family had a number of contacts with the French counts. After the death of François Beaujot, Justine Beaujot became housekeeper to the priests and the family resided at the rectory (Payot and Beaujot, 1980: 57). This rectory was previously Bellevue, the residence built by Count Yves de Roffignac.

Eugène and Félicien, the two sons of François and Justine Beaujot, subsequently worked for Counts Claude Alexis Joseph de Langle and Paul de Beaudrap de Denneville (Payot, 1980: 58; Beaujot, 1980: 59; Driscoll, 1992: 5). Eugène also worked at the cheese factory, and Félicien trained and cared for horses, including bringing them to pasture in the Moose Mountain. Joséphine, the daughter of François and Justine Beaujot, and her husband Adolphe Gatin, also worked for Joseph de Langle, as housekeeper, cook and doing farm work on the ranch. In 1912 the Gatin family purchased the La Rolanderie property (Gatin, 1980: 110-111).

Joseph de Langle had come to Saint Hubert in 1887, purchasing section 17-14-2 and south half of 16-142, where he built a home and raised horses (Metzler, 2017). In 1887, he also bought a small general store in Whitewood (Léonard, 1987: 119, 165). He married Marie Joséphine in France in the winter of 1894, and they returned to France in 1901. Paul de Beaudrap had arrived in the Saint Hubert settlement in 1889, and his wife Yvonne née Ribard arrived a few months later. They built a home on SW 34-14-3 where their four oldest children were born. The family went back to France in 1899 but they eventually

\footnotetext{
${ }^{4}$ When the property of the Rolanderie Farming and Stock Raising Company was sold to the Archdiocese of Saint Boniface, there were specifications that the land could only be resold to French Catholics until 1921 (Metzler, 2017).
} 
came back to Canada in 1904, obtaining a homestead on SE 23-32-22-4, near Trochu, Alberta (deBeaudrap, 1980: 87-88) ${ }^{5}$.

\section{The Saint Hubert Parish}

In the community book entitled Memories of St. Hubert 1980, the first article is by Larry Smeets on "The 'French Counts' and the Origins of St. Hubert" and the second is by Dorothy Beaujot on "The History of the Church." While the core of the book presents family histories, several other entries in this book point to the importance of the parish as the basis for the community and its memories. There are articles on "Liturgical Changes" (Le Dressay, McCormick and L'Heureux, 1980), "The Choir" (Jeannot and Jeannot, 1980), "Knights of Columbus" (Balon and Boutin, 1980), "The Ladies of the Altar Society" and the "Joan of Arc Nursing Home" (Denis, 1980). Besides the section on "Priests through the Years", there are also pictures of the "old stone church"6 constructed in 1890 (p. 9), the second church taken in 19031904 soon after its construction (p. 41), the third church built in 1935 (p. 15). Another picture shows the congregation gathered in front of the church on its $50^{\text {th }}$ anniversary in 1940 (p. 52), and there are several pictures taken of the $90^{\text {th }}$ anniversary celebrations on 27 July 1980 (pp. 219-223).

In her article on "The History of the Church," Beaujot (1980: 9) starts by observing:

While the wild ventures of the French noblemen provided the initial attraction, the Catholic Church provided continuity and a point of community identity. The parish was called St. Hubert and gradually this name replaced "la Rolanderie" as the name of the district. The name change is significant as it is a symbol of the shift from the early noblemen to the church as the central point of identity for the district.

With the departure of the counts, there were certainly doubts with regard to the viability of the community. In the "Memoirs of Edmond Dunand", the author observes that "many would have gone back if they had had the money" (Dunand, 1980: 218). However, with the homesteads that they were developing, "they could see that there was opportunity in this new country."

Early records indicate that the counts nonetheless played a large role in establishing a Catholic community and a well-endowed parish. As of 1887-1890, Roman Catholic religious services were held at the home of Count Jules Gustave Ange de Beaulaincourt (Whitewood History Book Committee, 1992: 97). In 1889, Count de Roffignac and Baron van Brabant met with Monseigneur Langevin, Bishop at St. Boniface, to plan for the building of a church (Sullivan, 2009: 60; Hedsman, 1988). Abbé Léon Muller was the first priest, arriving on 5 April 1890. The crucial decision was made to build the church close to the community that was developing on the Pipestone (on SW 3-15-3), rather than in Whitewood. Father Muller stayed at the La Rolanderie residence to oversee the construction, but by August 1890 he was

\footnotetext{
${ }^{5}$ When Memories of St. Hubert 1980 was being written, a dusty old box from the church basement was opened. It was found to contain items from the de Beaudrap family. Betty Adam (then Betty McCormick) followed up with their address in France and eventually located the family in Alberta. Their grandson Pete wrote an entry for the Saint Hubert book.

${ }^{6}$ The Kipling Citizen (26 August, 2000: 14) carries a photo of an artist's painting of the old stone church.
} 
back in Paris recruiting colonists for his distant parish to which he was never to return (Beaujot, 1980: 9; Sullivan, 2009: 60; Frémont, 2002: 124).

The construction of the church was financed by the nobles who did not cut corners. In his Les Français dans l'Ouest Canadien first published in 1959, Donatien Frémont (2002: 124) observes (author's translation):

In a country where all construction is in wood, the church has the incredible luxury of being in field stone, assembled by French masons. The single door, in carved oak, offers a rich artistic effect, as well as the eight windows, where the author used the son and the daughter of the one noble donors as models of the characters. Inside, there is a beautiful canvas of the Annunciation, by Count Divonne Forrest.

While it mostly treats the history of the French counts, the entry on Saint-Hubert in Musée Virtuel Francophone de la Saskatchewan (2017a) also treats the early history of the parish, including the arrival of the second priest, Father Henri Nayrolles, who served the community for 1891-1893 (Beaujot, 1980: 9). Father Nayrolles lived at the Bellevue residence that Count de Roffignac had built a quarter mile west of the church.

During the period 1893-1903, the parish was served by various priests from the area. It is during this time that we can place the story of the statue of Saint Hubert, sculpted by Marie-Adrienne Anne de Rochechouart-Mortemart (1847-1933), Duchess of Uzès ${ }^{7}$. This famous member of the French nobility had sculpted a marble statue of Saint Hubert with Hounds (1889), which still stands in the crypt of the Sacré Coeur Basilica at Montmartre, Paris (Sterckx, 2008).

At the request of the Baron of Boissieu, this Duchess sculpted a replica of the marble statue of Saint Hubert with Hounds, for the parish of Saint Hubert, under the condition that it first be exhibited at the Chicago World Exhibition of 1893. This World Fair is also known as the "Columbian Exposition" because it was to have taken place in 1892 , the $400^{\text {th }}$ anniversary of the arrival of Christopher Columbus to the New World. The statue was exhibited in the Fine Arts Department (Group 139: Sculpture) at the Women's Pavilion, entitled "Marble group-Saint Hubert," under the name of Mme A. Manuela, pen name of the Duchess of Uzès ${ }^{8}$ (Palmer, 1893: 80).

The following year, as the statue was to be shipped to Saint Hubert, the Baron de Boissieu observed that "the colony on the Pipestone had fallen on hard times" and it was no longer appropriate to send such a work of art to the new parish (Frémont, 2002: 128). After conferring with the Duchess of Uzès, the Baron offered to Archbishop Taché of Saint Boniface, Manitoba, that the statue be placed in the courtyard of the Bishop's residence. It stayed at this location until about 1985 when it was placed in the

\footnotetext{
${ }^{7}$ This Duchess of Uzès is also remembered as the first French woman to have a driver's license, obtained on 12 May 1898, and also the first woman to receive a speeding ticket for travelling at the speed of $15 \mathrm{~km}$ per hour in a $12 \mathrm{~km}$ zone in the Bois de Boulogne (court date of 7 July 1898).

${ }^{8}$ The documentation indicates that the sculpture is listed as Exhibit No. 108 in Class 820: Figures and groups in marble; casts from original works by modern artists; models and monumental decorations (Palmer, 1893: 80).
} 
Saint Boniface Museum. The story of this statue, and it never having been delivered to the parish, is long remembered.

In the early years of the 1900 s, when the counts had largely left, the archdiocese of Saint Boniface made arrangements with an order of priests and brothers from France to take over the parish. The Fils de Marie Immaculée, based at Chavagnes-en-Paillers, France (also known as les Pères de Chavagnes) were to serve the parish from 1903 to 1961 . At least 16 priests and 4 brothers of this order would eventually serve the parish (Hedsman, 1988: 132-133; see also Memories of St. Hubert 1980: 11, 42-46). From their base at the rectory in Saint Hubert, they also looked after other parishes or missions in the region. In 1929 there were four priests living in the rectory (Memories of St. Hubert 1980: 181).

The Fils de Marie Immaculée made arrangements with Archbishop Taché to purchase the land that the Rolanderie Farming and Stock Raising Company had sold to the diocese when the Company was no longer solvent. The priests then sold the land to the various settlers who wanted to remain in the community.

Father Jerome Boutin (1862-1928) was the first to arrive, serving as parish priest from 1903 to 1923. Father Boutin is the first priest listed in the section on "Priests through the Years" in Memories of St. Hubert 1980. He is remembered as a strong man, travelling as far as Dollard and Willow Bunch on missionary work with a team of horses and buggy or cutter, all the while attending a large summer garden and cutting his own firewood in winter (Memories of St. Hubert 1980: 42). In 1919, Father Boutin added Kennedy and Moose Mountain to his congregation.

On the arrival of Father Boutin in 1903, the church was moved two kilometers southwest, to the location where it now stands (on SE 33-14-3). In referring to this move, Frémont (2002: 129) uses the title "SaintHubert repart à neuf" (Saint Hubert starts again). This move put the church closer to the centre of the evolving farming community, taking advantage of the agricultural potential in the Golden Plain area to the south of Saint Hubert. The old stone church was demolished, with the stones being used for the foundations of the new church, now built of wood, and also retaining the eight windows, the oak doorway and the scene of the Annunciation. All these treasures of the past were lost when the church was consumed by fire in 1935 . The church that now stands is thus the third, with the first mass celebrated on 24 November 1935.

This history cannot be told without recognizing the strong contribution of Father Benjamin Fallourd, who came to the parish in 1904, becoming Parish Priest in 1918, until his death in 1949. He was a meticulous note-taker and responsible for much of what has been retained from the early history of La Rolanderie and Saint Hubert. He was a dedicated man in many respects: "Distance, inclement weather, adverse road conditions were no impediment when any of his parishioners required his ministry" (Memories of St. Hubert 1980: 43). In 1927, while participating in the construction of the parish hall, he suffered a fractured leg which eventually had to be amputated. It is well remembered that when children "played church," the child who was acting as priest would invariably limp, thinking that this was part of the role. 
The adults remember that Father Fallourd was not an orator, with sermons read first in French then in English, invariably starting with the theological observation that "There is only one God ... ." The services were always long, often with a "benediction" after the mass, making it an hour and a half in the best of times. For those coming from a distance of four to five miles, by horse and sleigh in winter when the roads were inaccessible to vehicles, one had to leave an hour before the service in order to put the horses in the stable during the service. With a half hour of socializing after church, the total time would easily be $3 \frac{1}{2}$ to 4 hours.

\section{Saint Joan of Arc Nursing Home}

In the spring of 1907, Father Boutin and Father Fallourd invited the Sisters of Our Lady of the Cross ${ }^{9}$ in Forget to start a small boarding school in Saint Hubert, first operating in the church basement (Denis, 1980: 20-22). A separate building was eventually erected, opening on 3 October 1921 as the Saint Joan of Arc Boarding School. Initially, some 35 students were registered but the numbers soon declined as a boarding school was not particularly appropriate in such a small community, and other public schools were becoming available.

By 1924, the boarding school could no longer operate, and the facility became the Saint Joan of Arc Nursing Home. The Sisters, who were already accommodating two elderly women and an infirm younger woman, admitted seven men and three women from the Wolseley Home on 31 May, 1924. This would be the beginning of a rather large operation, receiving patients from across Saskatchewan since it was the first Catholic nursing home in Saskatchewan as well as the second home for the aged in the province (Whitewood History Book Committee, 1992: 101). The property came to include a farm that supplied the meat, milk, eggs and vegetables needed for staff and patients. Other buildings were added to house the patients: St. Peters in 1927 and St. Roch in 1930 (Denis, 1980: 20-22). In 1946, electricity was installed with the Home's own generating unit. A new wing was added in 1960, including an elevator, a large dining room on the basement floor, a chapel on the main floor, and Sisters' quarters on the second floor.

The Saint Joan of Arc Nursing Home became an important institution in the community, also providing employment, and even housing in the hamlet for the family of one of the workers. In 1965, there were 108 patients with a staff of about 15 Sisters of our Lady of the Cross and some 15 other staff for maintaining the property, food production and patient care (Payot, 2017). The staff included Victor Beauregard who had come to Saint Hubert in 1920. As a single man, he left his nearby farm to become "farm manager" at the nursing home for 22 or 23 years, until its closing. Other young women from the community worked at the Home, including Anne Marie Gatin. Two women who had come to work for

\footnotetext{
${ }^{9}$ This order of sisters was founded in France by Sister Adele de Murinais. Because of religious persecution in France, three sisters had been sent to Forget, Saskatchewan, in 1905 (Denis, 1980: 20).
} 
the sisters later married men from Saint Hubert: Rolande Beaulac from Debden married Albert Gatin in 1958, and Rose Chrétien from Debden married Francis Payot in $1968 .^{10}$

At a time when there was little or no public funding for the elderly, the Sisters were making an important contribution toward the care of the aged and disabled. At the request of the Federal Department of Health and Welfare, the Sisters were also asked to provide work experience to young girls with mental disabilities from the Moose Jaw Training School (Whitewood History Book Committee, 1992: 101; Leclair, 2017).

Not only was the work of the Sisters largely unpaid, but the Home was mostly self- sufficient in meat, eggs, dairy products and vegetables. Including patients, sisters and staff, the farm was feeding some 150 people. There was a barn with some 25-30 pigs, 20-25 cattle for milk and meat, along with hens and chickens for eggs and meat. The vegetable gardens extended over about a quarter section (Gatin, 2017). The animals were butchered and dressed on site. Beans, peas, tomatoes and pickles were canned, while potatoes, carrots, onions and beets were kept in the root cellar. When fresh fruit was available, it was also canned for winter consumption. After electricity became available, the walk-in cooler and freezer were also used for preserving vegetables and meat.

When Sister Therese Leclair arrived as cook in 1965, she remembers looking for "all kinds of recipes" to use the "ton of peas" that had been preserved (Leclair, 2017). As peas and beans were being brought in from the gardens, the patients enjoyed doing their part in preparing them for preservation. One year, there were so many peas that the wringer from the washing machine was used to shell the peas. The preserves were boiled in two-quart sealers placed in a large cauldron, with a wood platform for holding the sealers, directly above the fire. Sister Leclair remembers preserving some 800 quarts of each vegetable.

It was a surprise to the community when the Home closed in 1968. In spite of the new wing, other buildings were not keeping up with the evolving regulatory standards, and there were diminishing numbers of available Sisters. It was difficult to keep other staff because of the low wages and the few facilities for young adults at Saint Hubert. At closing, the remaining 80 patients were transferred to other nursing homes and hospitals (Denis, 1980: 21-22). Since their arrival to Saskatchewan from France in 1905, the Sisters of Our Lady of the Cross had served especially in education, and the care of the sick and elderly (Raiwet, 2017). However, by 2017 there were only four elderly Sisters remaining.

As commentators have invariably noted, the Roman Catholic Church played the key role in establishing and maintaining the Saint Hubert community. The transfer of the property of La Rolanderie Farming and

\footnotetext{
${ }^{10}$ Anne Marie Gatin, Albert Gatin and Francis Payot are children of Leon Beaujot's first cousins Emile Gatin and Mathilde Payot (see Appendix 3.1). Rolande Beaulac is the sister of Grace Beaulac who would marry Leon's brother Albert Beaujot.
} 
Stock Raising Company, first to the diocese of Saint Boniface, then to the Fils de Marie Immaculée, ensured the church's strong role in the community as this land was eventually bought by people sympathetic to the church. The church was well placed to unite French, Walloon and Flemish settlers, and eventually others in a multi-cultural setting based on Roman Catholicism (see Jaenen, 2011).

The Church was important for a common sense of values and a link to a broader world. It was also through the Church that individual rites of passage were marked, from birth, through to adult responsibilities, marriage and death. Many community events took place on church property. The basement of the church served for gatherings and soirées of various kinds, and the grounds of the church served for sports, especially ball games, and the annual picnic. As of 1936, films were shown on Sunday evenings in the basement of the church.

The Church also controlled the social life of the community. Frémont (2002: 131) notes that the priests were able to keep their parishioners together and attached to the land by providing young people with healthy activities ("amusements sains") such as cinema, sports and theatrical evenings. Of course, this was to the exclusion of "amusements non-sains" such as dancing, alcohol and improper attire. The films to be shown had to be previewed by the priest. I recall an occasion after Sunday mass, when Emilie Poncelet (née Gatin), a young married women at the time, sought to determine whether she could come to the picnic in the afternoon wearing the same clothes as she had worn at church, but without the sweater that was covering her mostly sleeveless dress. She came up to Father Bordet in the middle of the gathered crowd, pulled her sweater over her head and asked if she could come to the picnic that way. The blushing priest bit into his vow of chastity and turned away saying "no."

After the departure of the Fils de Marie Immaculée in 1961, the parish was served by priests from the diocese of Regina, who mostly did not speak French. In about 1965 the inside of the church was completely remodeled, with the altar facing the congregation. In 1970 the priest's residence was moved to Whitewood, with the priest serving the parishes of Whitewood, Broadview and Saint Hubert. The members of the parish took increasing roles, first on the Parish Council, and eventually in leading prayer services. In 1975 the church basement was renovated so that it could continue to be used for fall suppers and weddings. In 1980, there remained a sufficient number of dedicated volunteers to undertake the community book project: Memories of St. Hubert 1980. As an indicator of the size of the community, the Saint Hubert members of the Knights of Columbus numbered 22 men at this time ( $p$. 18).

With the younger generation leaving the area, church attendance continued to decline. Sylvian Dumonceaux, who in 1969 had been the first President of the Parish Council, recalls an occasion in about 1985 when he had driven his daughter Stephanie in minus 30-degree weather to play the organ at Saturday night mass. There were only seven people at the service. On the way home, Stephanie proposed that the church could easily be closed, and that three of the attendees could go to the service in Whitewood and four in Kennedy. 
In effect, after the $100^{\text {th }}$ anniversary in 1990, the Saint Hubert Parish was officially closed. At first there was an attempt to hold an annual service and picnic, but that too has stopped. Nonetheless, there remains sufficient community dedication to maintain the "old" cemetery on the hill where the stone church once stood, and the current cemetery (see de Laforest, 2017). In 2011 a new roof was put on the church so that it could withstand the weather for several years to come. The church stands unlocked, open for all visitors and for the occasional special event.

There are several Beaujot and Mullie connections to the records of the Saint Hubert Parish. François Beaujot, who had arrived in 1892 at the age of 70 and died the same year, was the first person interred at the old cemetery while Justine Beaujot, his spouse, was the third person interred in the new cemetery in 1904 (see Appendix 3.1). As previously noted, Justine Beaujot was for a short time the housekeeper to Farther Nayrolles, living at the rectory which had been built as Bellevue by Count Yves de Roffignac. The fathers of Leon and Dorothy Beaujot spent the last days of their lives at the Joan of Arc Nursing Home: Félicien Beaujot in 1944-45 and Paul Mullie in 1965-1967. Albert Beaujot, Leon's older brother, worked at the Home as of the early 1940s, then full-time in 1952-1963. Before building his own home in the hamlet, Albert lived with his parents Félicien and Bertheline Beaujot in the house that belonged to the Home. As noted above, Dorothy Beaujot wrote the section on "The History of the Church" in Memories of St. Hubert 1980, and in the separate section on "Liturgical Changes" Leon Beaujot and Gabriel Decelle are listed as the first lay readers in 1963, while Leona Beaujot and Marie Dartige were the first women readers in 1970 (p. 16). In the entry on "The Ladies of the Altar Society," Mrs. Paul Mullie is indicated as the founding president, in the early 1930 s.

The Saint Hubert Church was full once again at the internment of the ashes of Leon and Dorothy Beaujot, on 4 June 2014, following an uplifting mass concelebrated by Father Rene Manghas of Whitewood and Father Hector Seveille of Kennedy.

\section{The Saint Hubert Community}

The Saint Hubert district never had defined geographic boundaries. The district can be defined as the area from which Catholics came to the religious services at the Saint Hubert Parish. By looking at the rural municipality maps showing the owners of the original homesteads and the current occupants of the land, the district can be defined as an area, centered on the church, eleven miles across and seven miles north-south ${ }^{11}$. The maximum distance from the church would have been a journey of about an hour by horse and sleigh when the roads were not accessible to automobiles, including the time needed to put the horses in the barn on arrival.

\footnotetext{
${ }^{11}$ From the church, this area would reach six miles east (that is, two miles beyond the No. 9 Highway, following at a distance of three miles east of the highway as one travels south) and five miles west of the church (that is, two miles into the Kingsley Rural Municipality). The area would also go three miles north of the church and four miles south of the church.
} 
While the agricultural and industrial enterprises of the French counts were not successful, the people left behind were a step ahead in forming a vibrant rural community. They had come to work for the counts, but they hedged their bets, taking homesteads and becoming property owners and farmers. The Saint Hubert Church in particular was well endowed, with most of the land under the ownership of the counts having been passed to the Fils de Marie Immaculée, the order of French priests and brothers who had taken responsibility for the parish. The continuing occupants could profit from the bargain prices, especially for the homes and buildings that the nobles had left behind.

The departure of the counts also made for a community with markedly fewer class distinctions. This encouraged solidarity and inter-family assistance in times of need and when several workers had to collaborate in matters ranging from harvesting to the construction of homes, barns and other buildings. The failed enterprises of the counts may also have prompted the remaining inhabitants to find creative solutions to successful farming in the ecological and climatic conditions of the area of Canada's NorthWest that was to become Southern Saskatchewan. The Catholic religion and French language meant a community with similar values and a determination to hold together in a broader environment where the Protestant religion and the English language were dominant.

With regard to the size of the community, the best indicators come from the archives of the Archdiocese of Regina. This would indicate that the parish grew from some 12 families (49 "souls") in 1903, to reach a peak of 58 families (321 souls) in 1953, with the latest available data showing 26 families (63 souls) in 1988 (Klein, 2017) ${ }^{12},{ }^{13}$. Looking at the occupied farm sites from the Rural Municipality Maps, the 2017 count would be 17 families (50 people) living on farms that would previously have been part of the parish.

The most reliable figures are for families, indicating only 12 families in 1903, reaching just under 60 families in the early 1950s, down to 26 in 1988 and 17 in 2017. Families would have been smaller in 1903 , since they had recently arrived. The maximum size of the parish community would have been at the time of the baby boom of the 1950s (average of 5.5 souls per family). By 1988, the young people were leaving the community, bringing the average to 2.4 persons per family.

The "Family Histories" section of Memories of St. Hubert 1980 provides further indicators of the size of the community (pp. 53-213). There are a total of 166 entries and 87 distinct family names. In addition, to these "Family Histories", the section of the book on "Groups of Histories" has shorter entries for 29 individuals or families who were associated with Saint Hubert for short periods (pp. 213-217).

The "Family Histories" are organized alphabetically, with the first entry on a given family name being those who first arrived in the Saint Hubert community. In all but six of these 87 entries, the country or

\footnotetext{
${ }^{12}$ Father Fallourd is quoted to the effect that there were 88 French and Belgian arrivals between 26 March 1892 and 4 October 1893 (Guitard, 1977: 112; Smeets, 1980: 6). However, it is difficult to determine how many of these stayed in the community.

${ }^{13}$ These data do not include the patients of the Saint Joan of Arc Nursing Home, nor the Sisters of Our Lady of the Cross.
} 
province of origin of the family is also given. Among the 81 entries where the place of origin is indicated, 19 are from France, 17 from Belgium, 12 from Ontario, 6 from Quebec, 6 from elsewhere in Saskatchewan, 2 from Manitoba, and 1 from Alberta. Some of those from other provinces would have been of French or Belgian origins. There are another 12 countries of origin among these 81 entries: 3 from each of England, Hungary, 2 from each of Switzerland and United States, and 1 from each of Austria, Czechoslovakia, Denmark, Germany, Ireland, Poland, Romania, and Scotland.

This listing of family histories indicates both the numerical importance of French and Belgian origins, and the multi-cultural diversity of the community. The dominance of French and Belgian origins is indicated by the fact that, among the names that have more than one entry, 41 of these additional entries are in families with Belgian origins, 19 with French origins, 7 with origins in Quebec, 5 from Ontario, and 1 from each of Alberta, Manitoba, Czechoslovakia, Germany, Switzerland and United States.

In terms of having families in the community over generations, Belgian origins are clearly the most numerous. In his book on Belgians in Western Canada, Jaenen (2011) observes that Belgians were quite open to multi-culturalism, given that they already comprised Walloon and Flemish diversity, and that they were not numerically dominant in any region of western Canada.

Compared to the French, Belgians were probably also more open to adopting the English language. Already in the 1930s the younger generation mostly communicated among themselves in English. Although they were at first a small minority, the presence of persons who did not speak French brought the parish priests to give the sermon in both languages. As of the 1930s and 1940s, interaction in the community was increasingly in English, except in speaking with the older generation. English was the language of interaction in the broader society, and the community was too small to maintain a separate language. Even at the convent school, which the French-speaking Sisters of Our Lady of the Cross operated between 1921 and 1924, most of the instruction was in English. At the Saint Hubert School that opened in 1911, the provincial curriculum did not include French. In the early years, when the teacher was French, there would be a French class at the end of the day. ${ }^{14}$

$* * * *$

As indicated earlier, the Sisters of Our Lady of the Cross first brought schooling to the community in $1907^{15}$. Then in 1911, the St. Hubert School No. 2770 built a district school on SE-33-14-3, with the

\footnotetext{
${ }^{14}$ Various movements, especially the Orange Order, promoted English as the dominant language, and Protestant Christianity (Waiser, 2005; Savage, 2019; Bartley, 2021). Under Premier J.T.M. Anderson (1929-34), the governing Conservative Party of Saskatchewan had outlawed crucifixes in Separate Schools. There are even stories of Ku Klux Klan burning crosses on a hill north of Langbank in the late 1920s. Like St. Hubert, Langbank was homogenous with Anglo-Protestant ethnicity and religion (McClement, 2017). When advertising for a teacher in the 1940s, the Chair of the Golden Plain school board included "only Protestants need apply", but he was called out by another Protestant member of the local board. The prejudicial attitudes have since largely disappeared. For instance, in the 1970s, the members of the Whitewood Masonic Lodge and Knights of Columbus would sometimes arrange to have their meetings in the same evening in order to have coffee together (Dumonceaux, 2020).

${ }^{15}$ See the earlier section on the Saint Joan of Arc Nursing Home, which had first operated as a boarding school.
} 
school barn built in 1914 (McCormick, 1980a: 23-25). In 1921, the school was moved to a more central location near the church, and in 1949 a two-room school was built. Over the years, there were a total of 23 teachers, of which 12 were Sisters. Class pictures from 1941 and 1957-58 show a total of 30 and 25 students respectively. In 1966, the school was closed, and the 17 students were bussed to Whitewood and Langbank (Boyd, 2017).

In 1915, the St. Hubert Mission post office came into existence, closing in 1968. Starting in 1913, a rural telephone system was established, based in Whitewood. The telephone used "party lines" with several households on the same line. Each household had a distinct combination of long and short rings, but these were heard in all the households of a given "party." Within a "party," one simply called the person by ringing the appropriate code. One particularly long ring was used if all households were invited to the line. But people other than the person called could always "listen in." This was seen as a way of remaining informed about one's neighbors, and it reduced people's isolation. In 1979 the rural telephone system was amalgamated into Sask-Tel with each household having its own line.

In the section on "Entertainment" of Memories of St. Hubert 1980, Maria Mullie (1980: 33-36) starts with the parish picnics which were held as far back as the early 1900 s or possibly earlier. There were men's ball teams organized and competing with other teams of the area, and in 1936 the St. Hubert Ladies Softball Club was organized. Ball tournaments, along with children's races were a central feature of the annual picnic, as was the outdoor food provided by various booths. Edmond Dunand (1980: 218) provides further descriptions of these picnics:

I remember the St. Hubert picnics in the old days. They had all kinds of sports. The Whitewood band would play at intervals and there were horse races. There were all kinds of races for men, children and ladies. There were egg and spoon races, three-legged races and more. Everyone was kept busy. The most entertaining was the greased pig race. It was some chore to run and catch one, but to hold one was something else because it was so slippery. Some caught them by the tail but all they got was a greasy hand! There was a lot of laughter over this race. ... Then there were the pie throwing contest, ball throwing (hit the nose of a portrait of a man), nail driving contests and target shooting.

Ladies were busy serving homemade ice cream, meals and homemade pies - all made on wood stoves and there were no fridges. The social and community spirit made for a real fun day for children and parents.

People came to these picnics from as far away as twenty or twenty-five miles.

In the winter, hockey and skating parties were popular. There were dances, first in people's homes, then in the school, and eventually they were allowed in the parish hall below the church. The parish hall was also the location of fall suppers, concerts with plays, singing and talent nights, bingos, crokinole and card parties. April 21, 1946 is remembered as the date when the first talking picture show was seen at the parish hall. The projector was owned by the Sisters, and the parish paid for the film (Mullie, 1980: 33). Previously, as early as 1936, there had been silent movies. Emile Gatin ran the projector and the film was run three times, once to receive the approval of the parish priest, once at the Joan of Arc Home, then at the parish hall on Sunday evening. At the school, the children's Christmas concert was the 
highlight of the year. In 1955, a curling and skating rink were built, providing a further gathering place in the long winter months.

The Rural Municipality of Silverwood No. 123 played a significant role in community services

(McCormick, 1980b: 26-29). The first bylaw, passed in 1912, was the "Herd and Law Bylaw," preventing large animals from running at large between 15 May and 31 October when the crops were in the fields. ${ }^{16}$ In 1913 taxes were paid at $\$ 2.00$ per quarter in cash (equivalent of $\$ 43.30$ in 2017 ) and the balance in roadwork, then known as "statute labour."

During the depression years of the 1930s, when the prairies were also affected by a serious drought, the Municipality of Silverwood sought to provide various forms of assistance. Seed grain, animal fodder, and grasshopper poison were provided, and food relief was organized (McCormick, 1980b: 26-29). Children could receive one cent for a crow's egg, two cents for a pair of crow's legs or a gopher tail, and three cents for a rat. This system of pest control continued into the 1950s, with teachers being responsible for making the payments in exchange for the specified bounty. During the 1940s and 1950s warble fly powder and equipment were supplied, and in 1946 the Municipality assisted in testing cattle for tuberculosis.

It was also in the depression years that medical services were introduced by the Rural Municipality of Silverwood. Already in 1912, a Health Officer had been appointed. As of 1934, the Municipality provided all residents with prepaid medical services, with surgery being added to the municipal medical scheme in 1942. Thus, public healthcare was first offered through the Rural Municipality, until 1953 when the Silverwood Rural Municipality entered the Regina Rural Health Region (McCormick, 1980b: 26-29).

Municipalities were also responsible for roads and other constructions. In 1938, surplus labour was used to build a dam with stones and earth, at the end of McKay Lake (Pipestone Lake), some 5 miles northeast of the church. In the late 1920s, the people of the Saint Hubert area made a case for the proposed Number 9 highway to pass through Saint Hubert, on the route between Whitewood and Kennedy. However, the Saskatchewan Government rejected the plan in favour of the more direct route

\footnotetext{
${ }^{16}$ Before fences were built around the farmland, the cattle needed to be controlled. The entry on the "Joseph Cottin Family" in Memories of St. Hubert 1980 (pp. 77-81) tells the story of Mrs. Cottin (née Caroline Sommeilier) as she earned 40 cents per head to keep a neighbor's cattle under control for the summer. The Cottin family were living on their homestead (SW 4-14-3) that would eventually be purchased by Leon and Dorothy Beaujot from Harry Adams. In about 1896 she would take her baby (Michel) "in a wheelbarrow while she rounded up the cattle on foot. One evening she was having difficulty finding the herd, so she left the baby in the wheelbarrow near a slough. As she wandered around, she came upon Harry Cummins' dwelling and he volunteered to help her with a team of horses. In the meantime, it had started to rain and hail. After the cattle had all been started on their way home, the mother couldn't remember the exact location where she had left him. With the coming of darkness, the coyotes had started howling so Harry Cummins headed his horses towards the noisy coyotes and sure enough there was the youngster in the wheelbarrow, none the worse for his heavenly drenching and the company he had attracted with his own crying" [story related by Reine Le Dressay (1980: 78), daughter of Michel Cottin].
} 
between Whitewood and Langbank that was built in the mid-1930s. This meant that St. Hubert was never on a major road route, with the Number 9 highway located $8 \mathrm{~km}$ from the hamlet.

Besides the church, rectory and Joan of Arc Nursing Home, the hamlet of Saint Hubert came to include a school, post office, grocery store, credit union, garage, café, and curling and skating rink. A cooperative grocery store operated in the district in the period 1910-1914, but it was destroyed by fire in 1914 (Flick, 1980: 31). In 1935, a store was built in the hamlet itself, being incorporated as the St. Hubert Co-op in 1941, with a Credit Union being added in 1943. All supplies, including those for the Joan of Arc Home, had to be hauled out from Whitewood, which meant horses and sleighs in the winter months. Henry Flick (1980: 31) recalls an occasion in February 1947 when 14 teams started out in the early morning: Half of the drivers loaded their sleighs in the early afternoon and returned before dark. The other half stopped at the Whitewood pub, picking up their loads in the later afternoon, and started back after dark when it was difficult to find the trail. They went cross-country, with the first sleigh breaking trail, then letting the place for the next driver to go first. Facing difficult terrain, some of the sleighs upset, forcing all to stop as they tried "to pick up a load of coal that had upset in two or three feet of snow, ... barrels of coal oil that had tipped off the sleigh, ... and hundred pound sacks of potatoes that had rolled down the hill in the middle of the night, ... finally arriving back at the store at 3:00 am."

By the late 1950s, the store was in financial difficulty with more people driving to larger towns for supplies, and it finally closed circa 1970.

Over the period circa 1941-1972, there were 14 homes in the hamlet (see Flick, 1980: 32-33)17. In 1944, Félicien and Bertheline Beaujot occupied the home built by the Joan of Arc Home, along with their son Albert who worked at the Home. Albert Beaujot and his mother continued to live there after Félicien's death in 1946. Then, in 1952, Albert built a home for he and his mother next to the cemetery, which they occupied together until Bertheline's death in 1955 and Albert's departure in 1963. At this point the house was sold and moved to Whitewood.

As with many other rural communities, especially those that were removed from major routes of rail or road transportation, the Saint Hubert community underwent a serious decline in the 1960s. The school closed in 1966, the Joan of Arc Nursing Home and the Saint Hubert Mission Post Office closed in 1968, with the grocery store closing in 1970. By 1971, when the priest's residence had been moved, there were no occupied homes and no businesses left in the hamlet.

After its $100^{\text {th }}$ anniversary in 1990, the Saint Hubert Church was closed, with the building being used only on special occasions. Based on the maps for the Rural Municipalities of Silverwood and Kingsley, in

\footnotetext{
${ }^{17}$ Victor Gatin, who was employed at the Saint Hubert Co-Op grocery store as a teenager in 1950-52, has made a miniature display board for the Whitewood Heritage Museum showing 8 buildings and 14 homes as they existed in the 1950s (Metzler, 2017). The buildings are: curling rink, store, Praud's garage, school, church, rectory, plus the buildings of the nursing home (Joan of Arc, St. Roch, a grotto).
} 
2017, there were 16 couples and one bachelor on the farm sites that had once been part of the Saint Hubert district. Besides the 33 adults, there were 17 children, including 11 who were being bussed to school in Whitewood (population of 862 in 2016), Kennedy (population of 216) or Kipling (population of 1,074). The school at Langbank had been a K-12 school until 1985, when it became a K-8, closing completely in 2001 with the school in Kennedy offering K-12. In 2006, Grades 9-12 went to Kipling with Kennedy continuing as K-8.

The Rural Municipality maps also show another sign of change: the transfer of specific quarter sections to Reserve Status Land Status. Following on the 1992 Saskatchewan Treaty Land Entitlement Framework Agreement, 25 First Nations are scheduled to receive 2,052,123 acres of land, or just over $2 \%$ of the provincial land base (Nestor, 2017). The Cowessess First Nation is one of the parties to this Agreement that is settling First Nations land claims. For the district of Saint Hubert, the 2015 Rural Municipality map for Silverwood shows ten quarter sections that are either owned by Cowessess First Nation or in transition toward being Reserve Status Land for the Cowessess First Nation. There are also six quarter sections from the Kingsley Rural Municipality that are now owned by Cowessess. The Cowessess First Nation includes Nêhiyawak (also known as Cree) and Nahkawininiwak (also known as Saulteaux) Peoples who had signed on to Treaty 4 on 15 September 1874. The reserve at Crooked Lake was established in 1880, $55 \mathrm{~km}$ northwest of St. Hubert or $30 \mathrm{~km}$ north of Broadview, along the Qu'Appelle Valley (Thompson, 2017).

$* * * *$

When Rudolf Meyer came to the Pipestone Creek in 1885, calling his dwelling La Rolanderie, it would have been difficult to predict the future of the community of Saint Hubert, Saskatchewan. Meyer had managed to interest investors and nobles from France and Belgium to start a large operation that became the Rolanderie Farming and Stock Raising Company. This group, collectively known as the French counts of Saint Hubert, was successful in attracting capital and labour from France and Belgium. They were also adventuresome in undertaking large scale enterprises for the production of cheese, sugar beets and chicory, along with raising horses, cattle, sheep and pigs. While these ventures could have been successful, this initial group failed to establish themselves as a transplanted nobility in the early agricultural setting of Southern Saskatchewan.

The French counts were nonetheless successful in starting a well-endowed parish, and to leave their land, homes and buildings to the workers from Belgium and France who had accompanied them. The archdiocese of Saint Boniface arranged for the Fils de Marie Immaculée, an order of priests and brothers from France, to serve the parish, and later the Sisters of Our Lady of the Cross would establish the Joan of Arc Nursing Home as the second of its kind in Saskatchewan. The parish grew to some 60 families and 320 parishioners in the 1950s, while the Home would serve over 100 patients, with a staff or some 15 sisters and 15 other staff. Besides the church and home, there was a school, post office, grocery store, credit union, garage, curling and skating rink, along with 14 homes in the hamlet. Not being on a major transportation route, the community declined as of the 1960s to the point that the Saint Hubert Roman 
Catholic Parish closed at its $100^{\text {th }}$ anniversary in 1990, and by 2017 there are only 50 persons living in the former parish.

With this unique history, and the common sense of identity that had held the community together, the parishioners were able to publish an outstanding community book that has preserved its historical record: Memories of St. Hubert 1980. This was also the community that supported the lives of Leon and Dorothy Beaujot, and their parents Félicien and Bertheline Beaujot and Paul and Julienne Mullie, who had arrived between 1892 and 1911. We now turn to the four families of origin, along with their migration history from Belgium and France. 


\section{Chapter 3}

\section{The four families of origin in Belgium and France: Beaujot, Sénéchaud, Mullie, Smets}

This chapter treats the families of origin of the parents of Leon and Dorothy Beaujot, along with the continued contacts over the generations, across families in Canada and Europe. When I first undertook this writing project, I gave myself the task of finding all the first cousins of my parents. This turned out to be quite an adventure, taking me to various parts of Belgium and France. Little did I realize that I would find 92 people in this generation of first cousins of my parents (39 on my father's side and 53 on my mother's side). Through this, I also found 238 children of first cousins, that is second cousins on four sides in my generation (see Box 3.2 at the end of the chapter). The four genealogies are shown in Appendixes 3.1 to 3.4 at the end of Chapter 3.

Having looked at the circumstances that brought people to Saint Hubert, Saskatchewan, I can now place the family members who came to Canada within the context of others in the same generations who remained in Belgium and France. These comparisons bring an appreciation of how lives are affected by the momentous decisions of our ancestors. Since the families were mostly of rural origin, I pay attention to agricultural occupations over the subsequent generations. I also pay specific attention to how family members were affected by World Wars I and II.

Before describing the specific places of origin, I first consider push and pull factors that would have prompted the trans-Atlantic migrations.

Since they were based in rural areas, the Beaujot and Mullie families were probably influenced by the agricultural crisis of the 1880 s that affected the grain producing areas of Belgium. ${ }^{1}$ With cheap imports from America, this crisis undermined the price of wheat in Europe. On the Beaujot side, this affected the Namur region where there were larger farms, often operated with landless labour. On the Mullie side, this crisis also affected the southern part of West Flanders, already a densely settled and poorer area. Much of the population of this area was engaged in cottage industries (textile, tobacco) or as seasonal agricultural workers in nearby France. The crisis did not affect the Sint Truiden area of Belgium, where the Smets lived, since this was a fruit producing region, not known as an area of emigration. The Parthenay area of France, where the Sénéchaud family lived, was a poorer area, affected by floods, which had also suffered from the conflicts of the French Revolution, 1789-1799. This area of France, north-east of the port of La Rochelle, had already been an area of emigration during the era of New France, 1608-1760.

\footnotetext{
${ }^{1}$ After the U.S. Civil War of 1861-1865, massive wheat imports from America undermined prices in Europe. Belgian Socialists sought to keep bread prices low, thus lifting import restrictions on wheat. During the early stages of industrialization, Belgium was also slow in changing the tax structures towards the developing industries and thus land and agriculture were disproportionately taxed (Lesthaeghe, 2017).
} 
Besides the "push factors" associated with specific places of origin, there were also "pull factors," especially the opportunity to improve one's life chances on a developing frontier. The possibility of owning land, and developing one's property, must have played a role. While the homesteads were not exactly free, the Free Grants and Homestead Act of 1868, especially as promoted by the railway companies, must have been an important enticement, especially for people who had little opportunity to own property in Europe. Waiser (2007) even speaks of homesteads as fulfilling a utopian ideal of "promised land." Many who established themselves before the Great War were able to profit from good markets for grain, with marketing boards seeking to stabilize prices.

While they were all of the same size, and large by European standards, homesteads varied markedly in agricultural potential. The luck of the draw brought some to fail while others succeeded. The grid system also made for isolation from neighbors. Life on the frontier was not easy, and it was frequently said that "ce n'était pas comme on nous l'avait dit" ("it was not as we had been told"). While they did not always see their migration to Saskatchewan as definitive, the war of 1914-18, and the difficult rebuilding in Europe after the war, seriously undermined any plans to return.

\section{Places of origin in Belgium and France}

Three of the families of origin are from Belgium, while the Sénéchaud family is from France. Belgian origins also need to be related to the Flanders/Wallonia parts of Belgium. Belgium has two languages with French being the language in Wallonia, and Flemish is used in Flanders. The Beaujot family is from the province of Namur which is now the capital of Wallonia. The Smets family is from Sint Truiden which is in Flanders. The Mullie family is from Ploegsteert, a village that was originally in the Flemish speaking area of West-Flanders. As Belgium became a federal state with official language borders in the 1960s, Ploegsteert was attached instead to the francophone Hainaut province.

Thus, the Beaujot family is from Wallonia, the Smets are Flemish, the Mullie are from an area that is now part of Wallonia but was previously in Flanders, and the Sénéchaud family is from France. Since the Great War, some of the Mullie families have established themselves in France while others are in Belgium. We will now treat the specific places of origin, starting with the Beaujot family, which was the first to arrive in Canada.

\section{Beaujot}

There are two main sources of information on the Beaujot family. In the 1970s, I published a little book entitled Descendants of/de François \& Justine Beaujot 1860-1979 (Beaujot and Beaujot, 1979). This book traces all the descendants of the original couple, François and Justine Beaujot (grandparents of Leon Beaujot), who came to Canada in 1892. This couple had six children who lived to adult ages, four of whom established themselves in Canada, and two in Belgium. I received much help from Jules Parent and Maurice Godart who are from the two Belgian families. 
Besides the original couple, the book on the Beaujot family includes 301 descendants, and 122 spouses of descendants. At the time, there were six generations: François and Justine Beaujot are the first generation, their seven children are the second generation. The third generation consists of 20 first cousins, including Leon Beaujot. The fourth generation consists of 70 second cousins, that is, children of first cousins, born between 1904 and $1965^{2}$. Appendix 3.1 shows the four first generations in genealogical order.

The second source on the Beaujot family consists of two articles in a local history journal: Cercle d'études historiques de Gedinne. In this journal, Martine Parent (2006a, 2006b) published "Les ancêtres dinantais des Beaujot," and "La famille Beaujot. De Belgique au Canada. De Gedinne à Régina." These articles go back two further generations, to the grandparents, married at Dinant in 1778, of François Beaujot (see Box 3.1).

\section{Box 3.1 Two early generations of the Beaujot family, Dinant, Belgium}

Gérard Joseph Beaujot and Marie Jeanne Jacqumat (also spelled Jacmart or Jacquemart) were married at Dinant on 13 October 1778 , and had the following children, all born at Dinant:

1. Jean Joseph: b 18 October 1779

2. Henriette b 16 September 1780

3. Anne Joseph b 26 October 1781

4. Henri Joseph b 16 May 1784

5. Henri: b 28 April 1788

6. Julien: b 3 September 1789

7. Dieudonné: b 21 September 1791

8. Jean-Denis b 10 May 1792

Jean Joseph Beaujot (born on 18 October 1779) married Marie Agnès Dauri on 29 May 1811 at Dinant. Marie Agnès Dauri (sometimes spelled Davri, Davril, Davrid or David) was born at Leignon on 7 July 1786. The Beaujot-Dauri couple had the following children, all born at Dinant:

1. Ernest Joseph b 25 March 1812

2. Gérard Joseph b 6 February 1815

3. Jean Laurent b 14 May 1817

4. Louis b 8 May 1820

5. François Joseph b 19 November 1822 d 7 November 1892 @ Saint Hubert, Saskatchewan

6. Martin Joseph b 29 June 1825 d 1907

7. Louis Joseph b 24 September 1827 d 1893

These are the families of the father and grandfather of François Joseph Beaujot (see Appendix 3.1). He was one of seven brothers, the last one (Louis) had the King of Belgium as godfather and was known as Oncle Sept. There exists a handwritten family tree of the descendants of Martin Joseph.

Source: Parent, Martine. 2006a. Les ancêtres dinantais des Beaujot. Cercles d'études historiques de Gedinne. Revue 10, juin 2006, pp. 3-4.

\footnotetext{
${ }^{2}$ At the time of publication in 1979 there were 154 in the fifth generation and 50 in the sixth, but both of these generations were incomplete at the time.
} 
Martine Parent (2006a: 3) finds that it is at Dinant that the Beaujot (sometimes spelled "Baujot") family is found in parish and civic records. There are several records including the grandparents (married on 13 October 1778) and parents (married 29 May 1811) of François Joseph Beaujot (born in Dinant on 19 November 1822, died at Saint Hubert on 7 November 1892).

The Beaujots of Dinant often had the occupation of boatmen. They worked on the Meuse River between Givet (France) and Namur (Belgium). The Meuse River (Maas in Dutch) originates in France, flowing through Belgium (including Dinant and Namur) and the Netherlands, into the North Sea.

\section{The family of origin of Félicien Beaujot}

Jean Joseph Beaujot, the father of François Joseph Beaujot, was a miller at Dinant, at a lieu-dit called "Fonds de Leffe" (this location can be found on Google maps, $3 \mathrm{~km}$ northeast of Dinant). The Leffe River is a tributary to the Meuse and their mill would have been on this river about $1.5 \mathrm{~km}$ from the Meuse. Having four older brothers, François would not have inherited the mill at Fonds de Leffe. He worked at another mill in the vicinity of Lisogne (4.1 km east of Fonds-de-Leffe), owned by François Joseph Derenne, whose daughter Justine Pauline Joseph Derenne ${ }^{3}$ he would subsequently marry. In the period 1820-1850, there were 22 mills on the Leffe River. ${ }^{4}$ Since there was never a servicing railroad, the mills declined in subsequent years, with the last one being seriously damaged in World War II.

As son and daughter of millers, François Joseph Beaujot and Justine Pauline Joseph Derenne were married at Lisogne on 15 February 1860. They established themselves at the Cherzy Mill in Gedinne ${ }^{5}, 40$ $\mathrm{km}$ south of Lisogne. The Cherzy Mill was on the Hujon Stream at its intersection with the Houille Stream that then drains into the Meuse River at Gedinne. Martine Parent (2006b: 9) includes pictures of one of the buildings of the Cherzy Mill 6 taken in about 1900, and the ruins as seen in 2005.

Besides the mill, François and Justine Beaujot had about seven hectares of adjacent land used as pastures for animals and for growing crops. Disaster struck their cattle herd and they all died of some

\footnotetext{
${ }^{3}$ The parents of Justine Pauline Joseph Derenne were François Joseph Derenne (1792-1874) and Anne Celestine Joséphine Scieur (1802-1837), married in 1831. Anne Celestine Joséphine Scieur was born in Serville, 11 km west of Dinant.

${ }^{4}$ In a book entitled Lisogne se conte ..., published in 2012 to celebrate the $250^{\text {th }}$ Anniversary of the Château de Lisogne, Tanguay Van Outryve d'Ydewalle wrote a history of Lisogne that includes 5 pages on the mills of the region and in particular "Le moulin de Lisogne" that he now owns. There is reference to the Lisogne Mill dating back to the Middle Ages. In the period 1973-2011, it became the location of a restaurant called "La soupe aux choux". Le Moulin de Lisogne is now a tourist attraction with "Hôtel Cabanes," located at 60 rue de la Lisonette, Lisogne, 5501 Dinant. The town of Lisogne is $6 \mathrm{~km}$ from the mouth of the Leffe River, which is a km north of Dinant on the Meuse River.

${ }^{5}$ Jules Parent determined that there were no indications of presence of the Beaujot name in the archives of Gedinne before 1860 (see Martine Parent, 2006b: 11).

${ }^{6}$ The location of the Cherzy Mill can be found by continuing into the forest for about one km from the north end of rue de la Morie in Gedinne (in the other direction, rue de la Morie joins rue Albert Marchal). The Houlle Stream is about 100 meters to the left after the end of rue de la Morie, then continue for about one km to find the Hujon Stream where the mill would have been.
} 
unknown cause which may have been a disease or poisoning (Parent, 2006b: 10). The family reconstituted their herd, but when the cattle died a second time, they left the Cherzy Mill.

We know that the four oldest children of François and Justine Beaujot were born at Gedinne, between 1860 and 1868, and Marie Joséphine, their second child, died at Gedinne on 9 September 1869. The family must have left Gedinne in late 1869 or early 1870 since their fifth child was born in Patignies on 8 February 1870. François was an egg merchant in Patignies, then in Malvoisin, where their last children were born in 1874 and 1878.

When their last child (Félicien Beaujot, father of Leon Beaujot) was born on 8 June 1878, the family had lived in three places that are within $7 \mathrm{~km}$ of each other and $40 \mathrm{~km}$ from Dinant where the families of François Beaujot and Justine Derenne had lived. At this time, their six living children were under 18 years of age. Two years later, their eldest daughter would marry in Malvoisin: Léopoldine married Léon Poncelet on 25 June 1880 at the age of 19. Two of their daughters were married in 1892: Céline married Joseph Pirlot at the age of 24 in Brussels; Joséphine married Adolphe Gatin at the age of 22, on 12 February 1892, in Patignies. Malvoisin was the last place of residence of François and Justine Beaujot in Belgium.

\section{Coming to Canada}

At the time of their migration to Canada, arriving at Saint Hubert on 27 March 1892, François was 69, Justine was 56, and their children were aged 13 to 31. Four of their six children accompanied them: their two sons, Eugène and Félicien, their daughter Marie, and their daughter and son-in-law Céline and Joseph Pirlot. Staying in Belgium were Léopoldine and Léon Poncelet, who were living in Malvoisin and had four children at that time. Joséphine and Adolphe Gatin would come to Canada the following year, in 1893. Marie returned to Belgium in the fall of 1896, and married Marcellin Godart on 14 March 1897, in Patignies. The sons married later, Eugène (at age 43) married Modeste Ecolan on 27 April 1909 and Félicien (at age 32) married Bertheline Sénéchaud on 14 June 1910, both at Saint Hubert.

The family arrived in Canada with very few resources, except for clothes and kitchen items. It is remembered that they had cast iron kettles (chaudrons), a waffle iron, a mustache drinking cup and a feather quilt. On arrival, the family lived for a short while with the Moiny family who had come from Vonêche, Belgium, to work for Count de Beaudrap. In the spring of 1892, they lived with Father Henri Nayrolles in the "Bellevue" house that had been built by the Count de Roffignac, a quarter mile west of the old stone church. Justine Beaujot worked as housekeeper for the priest. There eldest son, Eugène, went to work on a farm in Griswold, Manitoba.

Before the family had its own cattle, they bought milk from a neighbour. The following story has been told over the generations: Arriving early to collect the milk, Félicien talked with the farmer who was finishing the milking, As can often happen, the cow swished her tail right into the milk pail just as the farmer was standing up after milking. Not wanting to waste the milk, the farmer placed the pale under 
the tail and squeezed out the lost milk. The Beaujot family decided not to buy milk from this farmer anymore.

In the fall of 1892, François was injured while loading a horse scraper (equipment for making ditches and building roads) onto a load of lumber in Whitewood. He was apparently unable to get help to load this scraper and the effort ruptured a blood vessel to the heart. On hearing of his father's condition, Eugène walked the distance of some $150 \mathrm{~km}$ from Griswold, to be with the family. François suffered for several weeks and died on 19 November 1892. While waiting for a priest to come for the burial, the body was laid in the cellar of the old stone church. He was buried during Christmas in the old cemetery close to this church. It was the first burial for this cemetery. A black metal cross marks the gravesite, next to the stone cairn at the site of the old stone church on the north bank of the Pipestone valley.

Céline and Joseph Pirlot worked and lived with Count de Langle, who was a bachelor at the time. After their arrival, Adolphe and Joséphine Gatin also worked for the Count de Langle, doing farm work on the ranch and as housekeeper and cook. Eugène and Félicien also worked for Count de Langle, raising and training horses, helping with the birth of colts, bringing horses to auction in Whitewood and wintering them in the Moose Mountain district. Eugène also worked for Count de Beaudrap and at the cheese factory that the counts had established in Saint Hubert.

From his work in raising horses for Count de Langle, Félicien had become very adept at training animals. This served him for the rest of his life. It is remembered that he had a well-trained dog named Pirame who was very good at rounding up the cattle (see the picture of Félicien and his dog on p. 59 of Memories of St. Hubert 1980). He also developed a strong ability to predict weather conditions, based partly on the behaviour of horses, who looked for shelter from an oncoming winter storm, with their heads pointing away from the wind. One winter, Félicien had become lost in the snow and he would have perished had he not been found and brought to warmth and food by Indigenous people of the district. He developed a healthy respect for winter conditions in Saskatchewan, even telling people to bring the shovel indoors in bad conditions, so as to be able to shovel one's way out in the morning.

Around 1900, Eugène established a homestead (SW of 36-14-3), two miles east of where the Saint Hubert Church now stands (see the homestead map of the Rural Municipality of Silverwood No. 123 indicating the homestead of Eugène Beaujot dated 1903-10-23) ${ }^{7}$. They built a sod house (maison en tourbe). A prairie fire burned in this area soon after, and the house would have been destroyed had it been built of wood. They later built a log house. They also bought a team of oxen and a walking plough. In 1904, Félicien purchased an adjacent half-section (NE and SE of 35-14-3) that the Canada N.W. Land Co. had owned as of 29 November 1887.

During this period, Céline and Joseph Pirlot also took a homestead in the Baynes district, about seven miles northwest of the present location of the Saint Hubert church. They built a sod house and lived

\footnotetext{
${ }^{7}$ The 1901 Census indicates three people with the Beaujot name: Eugene, Félicien (incorrectly spelled as "Felice") and Justine (their mother).
} 
there for a year or two. A severe hailstorm killed all their chickens and they decided to leave without having obtained the title to the homestead. Their eldest children were born at Saint Hubert, in 1892 and 1894. They then went to Oak Lake, Manitoba, where Joseph worked as labourer on the railroad, then Duluth, Manitoba, where they worked on the Plumb Lake ranch owned by J.D. McGregor, Lieutenant Governor of Manitoba (1929-34). Then, in about 1902 or 1904, they took another homestead some seven or eight miles from Redvers, Sask (N.W. 28-6-31) as the railroad was opening up this area.

After being at Saint Hubert for three years, Joséphine and Adolphe Gatin went back to Belgium in 1886 or 1887. Adolphe worked at the large glass and crystal factory at Val Saint Lambert, as a stoker. Their two children were born at Patignies and Yvot Ramet (Liège), Belgium in 1898 and 1901. The Gatin home is near the church (rue de l'Église) in Patignies.

In the winter of 1903-1904, at the age of 25, Félicien went back to Belgium for a visit and to persuade Joséphine and Adolphe Gatin to come back to Saint Hubert. They returned together making this the last trans-Atlantic trip in this generation. It was a rough 14-day ocean crossing. At age 3, Emile, their youngest child, was quite ill and the family was very worried because another child had died during the passage (Emile Gatin, 1980: 111). The fog was so thick that the fog-horn never stopped. The passengers felt the ship shudder during the night and found they had been side-swept by a freighter. They were relieved to land at St. John's Newfoundland. When they arrived in Whitewood, no one had come to pick them up, so they started to walk toward Saint Hubert. After crossing a place where the water was running deep over the road, they met Eugène Beaujot who had come to collect them with a team of horses and wagon. It was 10 April 1904.

On 8 May 1904, Justine Beaujot died at the age of 70, reaching the same age as her husband who had died 12 years earlier. In the last weeks of her life, she was visited by Father Jerôme Boutin. The bridge on the Pipestone had been washed out by the spring thaw and the priest had to go around by the Sunnymead bridge (now No. 9 Highway), making this a 10-mile walk. Justine Beaujot was the third person to be buried in the new St. Hubert cemetery. Although it was the month of May, it snowed on the day of her funeral.

When she came to Canada in 1892, Justine Beaujot had four grandchildren through her eldest daughter Léopoldine and Léon Poncelet. At the time of her death in 1904, her four daughters had a total of 12 children and her two sons Eugène and Félicien were still single. After Justine's death, she would have another 8 grandchildren, including a female child of Céline and Joseph Pirlot who died shortly after birth (1904). François and Justine Beaujot thus had 20 grandchildren, born between 1881 and 1919 (Léopoldine and Léon Poncelet: 5; Eugène and Modeste Beaujot: 3; Céline and Joseph Pirlot: 4 including one child who died soon after birth; Joséphine and Adolphe Gatin: 2; Marie and Marcellin Godart: 3; and Félicien and Bertheline Beaujot: 3). As seen in Appendix 3.1, this generation of first cousins, grandchildren of François and Justine Beaujot, would have a total of 70 children, born between 1904 and 1965. 


\section{The children of François and Justine Beaujot}

François and Justine Beaujot had seven children, with four born in Gedinne, one in Patignies and two in Malvoisin, Belgium. Six survived to adult ages, were married and had children.

The first to marry was Léopoldine and Léon Poncelet, both born in Malvoisin, had five children, born between 1881 and 1895, also born in Malvoisin. Their home, at 63 rue Ponceau, Malvoisin 6873, has remained in the family for four generations. Léon was maintaining roads in the community (Cantonnier Communal). After his day of work for the municipality, Léon would make wooden baskets, rakes and clogs (paniers, râteaux en bois et sabots). In his leisure time, he would spend long hours playing cards with the whole family. They lived in Malvoisin, where Léon died 1922 and Léopoldine in 1931. Both are buried in the Malvoisin cemetery. At the time of Léopoldine's death, they had 15 grandchildren. Léopoldine and Léon Poncelet would eventually have 16 grandchildren, born between 1904 and 1936 (Jules and Emilie Poncelet: 4; Céline and Honoré Gillard: 1; Agnès and Arthur Parent: 4, including one who died very young; Orpha and André Porrigniaux: 2; Laure and Auguste Berger: 5). Nine of their grandchildren were born in Malvoisin.

The home of Léopoldine and Léon Poncelet (63 rue Ponceau, Malvoisin) was subsequently owned by their son Jules and Emilie Poncelet, then by their granddaughter, Reine-Marie (Rosa) Deward, and later by their son, Claudy Deward (see the picture in Parent, 2006b: 13). Agnès and Arthur Parent lived in Rienne (48 rue Léon Mathieu). Their daughter, Marthe and André Parent, lived on the same street (82 rue Léon Mathieu, Rienne). The house at 48 rue Léon Mathieu is now the home of Thérèse (Parent) and Roland Clarimval, daughter of Marthe and André. Agnès and Arthur Parent, as well as Marthe and André Parent, are buried at Rienne.

Céline and Joseph Pirlot who were born three km apart, in Gedinne and Patignies respectively, and had four children born between 1892 and 1904. The first two children were born in Saint Hubert and the third in Deleau, Manitoba where Joseph was working on Plumb Lake Ranch. Their fourth child died at birth in Bellegarde, near Redvers, Saskatchewan, where the family had taken a homestead. In about 1914 or 1915, Céline and Joseph, with Frank, their oldest child, bought a farm in Morinville, Alberta. Céline died there in 1923 and Joseph in 1941. At the time of Joseph's death, they had 9 grandchildren. Céline and Joseph Pirlot would ultimately have 11 grandchildren, born between 1921 and 1946 (Frank and Jean Pirlot: 4; Irene and John Hancock: 4; and Jack and Cathy Pirlot: 3).

After Joséphine and Adolphe Gatin, both born in Patignies, came back to Saint Hubert with their two children, Adolphe first worked for Alexander Jeannot and the family lived at the homestead of Eugène Beaujot, Joséphine's brother and their ailing mother. Adolphe and Joséphine subsequently bought a quarter section (NW $1 / 4$ of 36-14-3), adjacent to Eugène's farm. The only buildings on their farm were a sod house and shed. They built a log house with willow wands nailed on the slant to hold the mud and lime filling. A frame barn was subsequently added, and they had milk cows, but water supply was a problem in the yard. Emile Gatin (1980: 111-112) continues his account by saying that it was the boys' job to take the cows to pasture after the evening milking. With no watches, the mother had made a 
sundial with sticks so they would be able to come home when the shadow reached a given location. One cloudy day, after playing around and climbing trees, they were not sure of the time but rounded up the cows with their dog. The cattle would not go where the boys were herding them and they ended up a mile away from home at 9:00 pm, at the cheese factory that the counts had built.

Ernest first went to school at Sunnymead, then both Ernest and Emile went to the boarding school at Saint Hubert. Their mother took in washing from the Sisters to help pay for room and board.

In 1912, the family bought the Rolanderie property and moved into this home that had been built by Rudolf Meyer in 1885-86. In the summer, Adolphe would go back to work on their other property. On a rainy day he had made a fire in the stove, but the rain continued so he returned home. In the afternoon, his brother-in-law Félicien saw smoke from his place some half mile west of there. He was able to determine that no one was home, but the house was a total loss.

All the farm work was done with horses. There were often runaways where the drivers lost control of the horses, especially with binders which made a mechanical sound that spooked the horses. Adolphe was once seriously injured with a runaway on a mower. Joséphine helped much with the farm work, especially at haying and harvest. The farm prospered and they built a large barn in 1921.

For entertainment, there was much visiting, dinners, ball games in the summer, always going home for chores, along with card games and dancing in the winter. Ernest played the double harmonica, with other musicians joining in. Emile learned to play the violin and Ernest the guitar, playing at home gatherings. They organized a baseball team, playing at the picnics at Saint Hubert, Kennedy, Fish Lake (now called Kenosee) and Round Lake, "but the chores were always waiting". Emile Gatin continues: "New Year's supper was the big thing at our house. After supper some singing, cards, dancing and after midnight lunch and tricks till two or three a.m."

Joséphine died in 1938 and Adolphe in 1940, both are buried at Saint Hubert. At Adolphe's funeral, Father Fallourd observed that "unfortunately he had only two children," born in 1898 and 1901, but he had redeemed himself through grandchildren, with already 13 born at the time of his death. Joséphine and Adolphe Gatin would ultimately have 16 grandchildren, born between 1925 and 1943 (Ernest and Anita Gatin: 6; Emile and Bernadette Gatin: 10). Bernadette (née Boutin) was born in 1903 in the village of Vasles, Deux Sèvres, France (near Parthenay).

Marie and Marcellin Godart were born in Patignies and Bourseigne-Vieille respectively. After Marie Beaujot returned from Canada in the fall of 1896, where she had gone with her parents in 1892, they were married in Patignies on 14 March 1897. They lived in Patignies where their children were also born: Adolphe in 1897, Cécile in 1903 and Maurice in 1906. Marcellin worked as a woodcutter (bûcheron) and Marie raised a few cattle, with also a lovely orchard. Marie died in Patignies in 1934 and Marcellin in Bourseigne-Vieille in 1942. Both are buried at Patignies. At the time of his death, Marcellin had 5 grandchildren. Marie and Marcellin Godart would ultimately have 6 grandchildren, born between 1925 and 1945. 
- Adolphe and Marthe (née Léonard) Godart were married in Patignies on 23 October 1924. They had three children, all born in Bastogne: Marguerite, Simone, Colette. Adolphe was a policeman in Brussels then Neufchateau and Bastogne, where Marthe was a seamstress. After retiring at an early age from the police service, Adolphe was named chief guardian of the Liers fort and FN factory (Fabrique nationale d'armes de guerre), near Liège.

- Cécile and Nestor Gerard were married in Patignies, and their two children were born in Patignies: Marcel and Yvon. Nestor and Cécile Gerard had a farm in Bourseigne-Vieille. They are buried in Bourseigne-Vieille.

- Maurice and Augusta (née Marchal) Godart were married in Bourseigne-Vieille on 26 December 1932 and had one child born in Bourseigne-Vieille: Louis. Maurice was a customs officer, finishing his career as chief of the customs and excise office at Willerzie $(6 \mathrm{~km}$ from BourseigneVieille). Maurice and Augusta Godart are buried at Bourseigne-Vieille.

Eugène and Modeste Beaujot were married in Saint Hubert on 27 April 1909. Based on information from a young person from France who was at Saint Hubert, Eugène corresponded with Modeste Marie Constance Ecolan, born in Médréac Ille-et-Villaine, France, who was interested in coming to Canada. She had previously worked as a cook's helper at the chateau of Saint Jacqueût de la Mer. Taking advantage of a trip to France by Mr. Niquidé, arrangements were made for him to come back to Saint Hubert with Modeste and her brother Alfred. They arrived in March of 1909. Modeste was 23 at the time while Eugène was 42. Pretending not to know the correct rules of etiquette, and trying to make himself look younger, Eugène kept his hat on to cover a balding forehead.

Eugène and Modeste Beaujot had three children, born between 1910 and 1915. The oldest children, Marcel and Mathilde, went to school in Saint Hubert, staying at the convent in winter but walking across the valley in the spring, along with their cousins Flora and Albert.

In 1918, the family had a deep well dug and borrowed money to buy more land. It was at this time that Marcel, their eldest, became very sick and had to be at the Moosomin Hospital for two months. More money had to be borrowed to pay for the hospitalization. Seeking to pay off the debt, the family made homebrew around the years 1921-26, during the prohibition period. There were many stories associated with selling moonshine, which went for $\$ 9.00$ per gallon. Sometimes men would drink at the farm and an occasion is remembered of someone sleeping the night on the kitchen floor (Mathilde Payot, 1980: 57-59). There was a code used to notify over the telephone (then a party line) that the police were in the area: "the yellow ribbons are flying south." Even the priest was known to come for a drink.

In 1927, when, as young teenagers, the two oldest children were "working out" (that is, out of the house), the family sold their farm (including Eugène Beaujot's homestead the SW quarter of 36-14-3) and in the following winter they lived on 12-15-3. There was a big house which wasn't finished on the inside. It was so cold in winter that the pail of drinking water was frozen every morning as they awoke to start the fire. With no walls, it was a great place for dancing, to which neighbors came as often as twicea-month. Over the next five years, they were at three different locations, ending up at 9-15-3 which Marcel and Emile bought from Father Fallourd. Mathilde was married in 1934. This was the middle of 
the 1930s recession and the dust bowl conditions on the prairies. Mathilde's future husband, Emile Payot, had bought the land where the family had lived until 1927. This farm remains in the family to this day, having been owned by Francis and Rose Payot and now Wayne and Sarah Payot. The farm of Wayne and Sarah Payot consists of the original homestead (SW $1 / 4$ of 36-14-3) plus the SE quarter of the land that Félicien Beaujot had farmed between 1904 and 1919 (SE 1/4 of 35-14-3). Paul and Patricia Payot own the NE quarter of the previous land of Félicien Beaujot (NE 35-14-3). Marcel and Emile continued to live with their mother on 9-15-3 (the house is on SW quarter) until their mother's death in 1967, when they sold this farm and moved to Wapella.

Eugène died in 1950 and Modeste in 1967. Both are buried at Saint Hubert. Their four grandchildren, through Mathilde and Emile Payot, had been born between 1936 and 1947. Their sons, Marcel and Emile Beaujot never married.

Félicien and Bertheline Beaujot were married on 14 June 1910 in Saint Hubert. In 1904, Félicien had bought a farm (East $1 / 2$ of 35-14-3) adjacent to his older brother. By correspondence through the family of Victor Boutin of St. Hubert, Félicien came to know of Bertheline Sénéchaud of La Peyratte, France. The contact may have been made by Father Jerôme Boutin who had come to Saint Hubert in 1903 and was a friend of the Sénéchaud family in France. Bertheline came to Canada in 1910 and they were married on 14 June of that same year. The couple farmed the half section that Félicien had earlier purchased, with the house located on the SE quarter (East $1 / 2$ of 35-14-3). Their three children were born there within nine years of the marriage. Félicien built a stone crossing over the Pipestone creek so that Flora and Albert could walk to school in St. Hubert, along with their cousins Marcel and Mathilde Beaujot who were the same age. Flora and Albert started school the same year, in 1918, when Flora was seven. There were 30 students at the school, where the nuns taught in French ${ }^{8}$ (Driscoll, 1992: 6). The following year, Flora moved into the convent in order to make her first communion, living in the basement of the church. Flora Driscoll continues:

We had to sleep two to a single bed. My bed mate was Marie Louise Mullie, older sister of my future sister-in-law Dorothy. The convent was very strict, and we all had our chores to do. The only fun we had was when they poured the wash water from the laundry down a hill behind the church. We would slide down it on old cardboard boxes or in old tubs, whatever worked.

Having sold their farm in a failed attempt to move to California in 1920, the family then came back to Saint Hubert, where they purchased the Daley farm, 5 miles southwest of Saint Hubert (SW $1 / 4$ of 25-14-4 in Kingsley Rural Municipality No. 124). In 1927 they moved to a developing area at Handsworth but had to leave there in 1934 because of the dust bowl conditions. They farmed for a year in Amsterdam, south of Yorkton, then returning to the Saint Hubert area until their retirement in the hamlet of St. Hubert in 1944.

\footnotetext{
${ }^{8}$ Others remember that the language of instruction was English at the Sacred Heart Boarding School. It may be that both languages were used.
} 
Félicien died in 1946 and Bertheline in 1955, both are buried at Saint Hubert. At the time of Bertheline's death, she had 12 grandchildren. They would eventually have 17 grandchildren, born between 1933 and 1965 (Flora and Joe Driscoll: 6; Albert Beaujot and Grace Pelletier: 2; and Leon and Dorothy Beaujot: 9).

\section{Reconnecting across the Atlantic: The Beaujot side}

After the Gatin family returned to Saint Hubert from Belgium in 1904, the contact across the Atlantic was only by correspondence during the next six decades. In the third generation, the first visit was by Ernest and Anita Gatin in 1965. Martine Parent (2006b: 19) remembers this visit at the home of her grandparents Agnès and Arthur Parent. The next visit was by Leon and Dorothy Beaujot, and Flora Driscoll, in 1976. They visited with descendants of the Beaujot family, both in the Gedinne region and at Liège. It is through this visit that contact was re-established with the families of Léopoldine and Léon Poncelet and Marie and Marcellin Godart. Leon, my father, subsequently prompted me to systematically collect genealogical information and family stories for the full set of descendants of François and Justine Beaujot. Two of our cousins from Belgium were particularly helpful in this project: Jules Parent for the Poncelet family, and Maurice Godart for the Godart family (Beaujot and Beaujot, 1979). In 1983, Roderic and Elisabeth Beaujot visited with the family in Malvoisin, Bourseigne-Vieille and Liège.

\section{Sénéchaud}

Of the four parents of Leon and Dorothy Beaujot, Bertheline Sénéchaud was the second to come to Canada, in 1910. Mother of Leon Beaujot, Bertheline is the only one of the four who never had a sibling living in Canada.

Bertheline Marie Sénéchaud was born on 4 October 1885 at La Peyratte, 10 km east of Parthenay, France. She was the fourth of six children born to Louis Alexandre Sénéchaud and Justine Léonie née Léau. As her two sisters and three brothers, she was baptized at La Chapelle-Bertrand, the adjoining commune to La Peyratte, where their parents had been married on 19 October 1880.

As the youngest surviving girl in the family, Bertheline may have feared having to stay single to look after her elderly parents. At the same time, Father Jerôme Boutin, who had been the priest at Saint Hubert since 1903, and a friend of the Sénéchaud family, was on the look-out for possible spouses for the single settlers of his new parish. Father Boutin would have enabled a correspondence between Félicien Beaujot and Bertheline Sénéchaud (Driscoll, 1992: 5). The family of Victor and Hélène Boutin, brother of Father Boutin, had also come to Saint Hubert from Pompaire (12.5 km from La Peyratte and 5 $\mathrm{km}$ from Parthenay) in 1908. Bertheline Sénéchaud would become the aunt by marriage of Bernadette Boutin, daughter of Victor and Hélène Boutin, when Bernadette married Emile Gatin, the nephew of Félicien Beaujot. 
Since her parents were very opposed to their daughter's departure, Bertheline left unannounced. After hiding her personal belongings in the basket of clothes that she was washing on the shore of the Thouet River, she got a ride to a larger town and worked as a maid to pay for the passage to Canada. The Boutin family or her future husband may also have sent her some funds to help pay the passage to Canada. Besides crossing the Atlantic she had to travel by train to Saskatchewan, an amazing journey for a young woman with no knowledge of English, at the age of 24.

The "Promesse de Mariage entre Félicien Beaujot et Bertheline Sénéchault (sic)" in the St. Hubert Marriage Banns and Parish Announcements (1903-1925) of the archives of the Archdiocese of Regina gives her full name as Marie Bertheline Emilienne Sénéchault (sic). This document, dated 28 May 1910, with a marriage date of 14 June 1910, gives Bertheline's parish as Pompaire (Deux Sèvres) in Diocèse de Poitiers, France. It may have been in Pompaire that Bertheline worked as a maid before coming to Canada, or it may have been at the port city of her departure.

Through www.familysearch.org, and entering Bertheline Sénéchaud, born in France in 1886, with "Canada" as the country, Jocelyn Molton (2017b) was able to locate Bertheline Seneschault (sic), age 24, on the passenger list of the Corinthian, arriving in Quebec city on 9 May 1910. The event type is indicated as immigration. Bertheline's destination is shown as Whitewood, Sask. The passenger list registered Bertheline as single, having never been to Canada, with the intention of permanently settling in Canada, able to read and write, with France as the country of birth, of French race, with no stated occupation in the country of origin, and the intended occupation in Canada of "domestic". The document also indicates that she had $\$ 40.00$ in cash (valued at $\$ 870$ in 2018 ), and it is stamped as "Continental Bonus Allowed". This Continental Bonus subsidized the passage of farmers and agricultural workers who were immigrating to Canada. The amount of the bonus was $\$ 6.00$, representing about $1 / 4$ of the $\$ 25.00$ cost of the trans-Atlantic trip on third class. The train from Quebec city to Whitewood, taking about four days to travel the $2,800 \mathrm{~km}$, would have cost about $\$ 15$.

The port of Havre is cited on the lower part of the passenger list. From various internet sources, it can be found that the Corinthian 2 was part of The Allan Line / Montreal Ocean Steamship Co that had the route London/Havre to Quebec/Montreal in the period 1888-1917. The steamship SS Corinthian was launched on 19 March 1900 in Belfast and it was wrecked on 14 December 1918 in the Bay of Fundy, with no loss of life. Earlier, the port at La Rochelle, closer to Parthenay, had served as an important port of departure, but as of 1905, with the Canadian Government subsidizing the Allan Company, Le Havre became the main French port for commercial relations with Canada. Being across the channel from London, it could serve both British and French commercial relations with Canada. Sales information indicates that the trans-Atlantic passage was always under 15 days.

The Manifest at the top of the passenger list indicates that the SS Corinthian of the Allan line had a tonnage of 6,045 with a date of sailing of 23 April 1910 from London and 25 April 1910 from Havre, and the destination of Quebec and Montreal. The summary indicates 952 adults and 112 children under 14 years of age with the "number of adults to which the total passengers are equal under the immigration act" of $10041 / 2$. ." There were 243 passengers in $2^{\text {nd }}$ cabin and 822 in steerage. The time of arrival at 
Quebec City is indicated as 6:00 am on 9 May 1910. The certificate of the ship's surgeon, signed on 9 May 1910 attests:

I certify that I have daily during the present passage made a general inspection of the passengers on the vessel and that I have at least once during the passage made a detailed individual examination of each immigrant on board and that I have seen no passenger thereon who I would have reason to believe is, or is likely to become, insane, epileptic or consumptive, or who is idiotic, feeble minded or afflicted with contagious, infectious or loathsome disease; or who is deaf, dumb or blind or otherwise physically defective or whose present appearance would lead me to believe that he or she might be debarred from entering Canada under the "Immigration Act" with the exception of the TWO persons whose names are enumerated on the "Ship Surgeon's List for Medical Examining Officer ... and that there were no deaths or births during the passage except those mentioned on the said list.

It is worth noting that, besides being a long trip ( 15 days by steamship and 4 to 5 days by rail), the services on this trip would only have been in English. Even though the departure is from Le Havre, the passenger list is in English. While Bertheline would probably have been able to find some people who could speak French, the language on the rail line, even in Quebec, would also have been English.

Leaving from France on 25 April 1910, Bertheline Sénéchaud arrived in Quebec City on 9 May and in Saint Hubert, Saskatchewan, on about 15 May. The promise of marriage was posted on 28 May and marriage to Félicien Beaujot on 14 June 1910 at Saint Hubert. Even though it was now June, it snowed on their wedding day (Driscoll, 1992: 5).

\section{The family of origin of Bertheline Sénéchaud}

Bertheline Sénéchaud's parents were Louis Alexandre Sénéchaud and Justine Léonie née Léau. Louis Alexandre Sénéchaud was born on 9 June 1856 at La Ferrière and died in August 1925 at Reffannes. His parents were René Sénéchaud (born 1811 or 1812) and Marie Sénéchaud (née Liege, born 1817 or 1818). Justine Léonie Léau (born 17 April 1861 at Parthenay) was the daughter of Pierre Léau (born in 1828 or 1829) and Marie-Madeleine Léau (born 1832 or 1833).

The above information is taken from the marriage certificate of Louis Alexandre and Justine Léonie Sénéchaud which was signed at La Chapelle-Bertrand on 19 October 1880. La Chapelle-Bertand and La Peyratte are adjoining communes some $10 \mathrm{~km}$ east of Parthenay. Pompaire, La Ferrière and Reffannes are 5, 13 and $15 \mathrm{~km}$ respectively from Parthenay, which is $380 \mathrm{~km}$ southwest of Paris. These towns and communes are all in the Departement of Deux-Sèvres, through which the Thouet River flows.

Married in 1880, Louis and Justine Sénéchaud had three daughters and three sons, all born within ten years of their marriage: Radégonde Angèle on 28 February 1882, Ernest Marcel Léon on 17 June 1883, Léon Henri on 25 October 1884, Bertheline Marie on 4 October 1885, Marcel Anathase on 16 April 1888, and Octavie on 2 March 1890. Their sixth child died three days after birth, on 5 March 1890. On 12 June 
1911, when Bertheline left for Canada, Radégonde would have been 28, Ernest 26, Leon 25, Bertheline 24 and Marcel 22. At that time, Radégonde was married with two children.

It is likely that Louis Alexandre and Justine Sénéchaud occupied the farm that was subsequently operated by their oldest son, Ernest Sénéchaud. This farm is close to the lieu-dit called "Le Four" in the commune of La Peyratte (see La Peyratte 79 Le four). Place names (or lieux-dits) were systematically recorded in the time of Napoléon. Le Four is located on the right (west) side of Route Nationale 149 going from Parthenay to La Peyratte, just before Route Départementale 165 that joins La Peyratte and La Chapelle-Bertrand. The farm would have been on the east side of D165, at this same corner. There is a short dead-end road and one can see the present farm some 200 meters beyond the fence. The location is sometimes called Le Panier Fleuri, after the name of a restaurant that was previously at this location. Le Four refers to an oven, but it is not known exactly how the oven was used; it may have been for heating limestone in making cement, or for making charcoal. It may just have been a sunny and wellprotected location where it was warm, like in an oven (Molton, Jocelyn, 2017a).

\section{The children of Louis and Justine Sénéchaud}

Louis and Justine Sénéchaud had six children, all born at La Chapelle-Bertrand, France. Five survived to adult ages and were married. We have the complete list of children of three of the five, but incomplete lists for the two other children.

The oldest of the Sénéchaud children, Radégonde, born on 28 February 1882, married Honoré Largeau on 25 February 1908 in Mazières en Gâtine (15 km south of Parthenay). Radégonde and Honoré Largeau lived in Parthenay where Honoré was a truck driver. They had four children: Bernadette (dite Marguerite) born on 12 January 1902, André born on 22 November 1908, Raymond born on 15 October 1910, and Marcel born in 1914.

- Marguerite and Clovis Gagnères were married in Parthenay on 24 October 1925. Clovis was in the military. He was a prisoner of war at camp Oflag XVII A in Austria from 22 June 1940 to his liberation in April 1945 as the Russian Army entered in Vienna and the Germans evacuated the prisoners. From July 1952 to July 1953, during the post-war occupation, Clovis was stationed in Freiburg-im-Breisgau, Germany. ${ }^{9}$ They lived in various places, retiring in Parthenay then Saumur. They did not have children.

- André Sénéchaud and Marie née Alnet were married in Mazières. They lived in Parthenay and had four children: André (called Dédé), Paulette, Bernadette, and Marie-Christine. André and Marie Largeau lived in a dwelling above their workshop (atelier) in Parthenay where André was a locksmith (serrurier) and constructed with metal. These same quarters were subsequently the home of their son, André (called Dédé) and Liliane Largeau, and now their grandson Jean François and Béatrice Largeau.

\footnotetext{
${ }^{9}$ Clovis Gagnères wrote two booklets: Ma carrière militaire and Mes mémoires de captivité. This account, along with that of Raymond Largeau, below, is thanks especially to Raymond's grandson, Martin Ménage (2020).
} 
- $\quad$ Raymond Pierre Honoré Largeau married Germaine Bernier on 22 April 1933 in Parthenay. Raymond was a carpenter and Germaine was a dressmaker. On 28 May 1944, Germaine and their 9-year old son Bernard were killed during the bombing of Angers. On 4 Sept 1939, Raymond had been called up in the French army during the general mobilization. He was captured by the Germans near Amiens, France. He became prisoner of war at camp Stalag III-B located in Fürstenberg, now called Eisenhüttenstadt, near the Polish border. The inmates were sent to work as Arbeitskommando in factories and farms. Raymond was freed by the Russian army on 6 June 1945, returning to Angers on 29 June to find that his wife and their $9 \frac{1}{2}$ year old son had been buried under the bombings of the Angers train station. Raymond subsequently married Germaine née Duveau on 4 June 1946 at Bazouges, Mayenne. In 1943-44, during the German occupation, Germaine had worked at the Mayenne prefecture in Laval. At that time there was no public transportation, with vehicles and fuel reserved for the German army. She had to cycle $60 \mathrm{~km}$ each day on the return trip from Bazouges, near Château-Gontier, where she lived with her parents. After their marriage, Raymond and Germaine Largeau first lived in Poitiers where they had a grocery store. In 1947 they left to live in Niort where Raymond was a carpenter. In 1951 they came to live in Saumur where they first had a small grocery store, then built their house at 3 rue Hoche, with a grocery store and storehouse on the ground floor and their residence above the store. Raymond and Germaine had four children: Christian (died at age 10), Maryvonne, Denis, and Anne.

- Marcel Sénéchaud and Joséphine née Petit were married in 1939. They lived in Surgères where Marcel was an electrician. Marcel and Joséphine Largeau had three children: Marcel (called Petit), Jacques, and Evelyne.

From their four children, born between 1902 and 1914, Radégonde and Honoré Largeau would have twelve grandchildren (see Appendix 3.2).

The second of the Sénéchaud children was Ernest Marcel Léon Sénéchaud, born on 17 June 1883. He married Noémie née Pillot on 12 June 1911 in La Peyratte. As described above, Ernest and Noémie Sénéchaud lived on the farm of the parents of Ernest, in the commune of La Peyratte, near the lieu-dit called "Le Four," that is also called "Le Panier Fleuri" after the name of a restaurant by this name that was once at this corner about halfway between La Chapelle-Bertrand and La Peyratte. Their farm was close to Route Départementale 165 that joins La Peyratte and La Chapelle-Bertrand. Ernest and Noémie had 15 children, born between 1912 and 1933, of whom 4 died at young ages and 11 were married.

The farm was about 30 hectares ( 75 acres), on which they raised cattle for market, and grew crops to feed the animals, and to pay the rent which was calculated in kind. From this farm they would go to the market in Parthenay with horse and cart. This Wednesday market was one of the largest cattle markets in France until the 1980s. From young ages, the children helped on the farm. Irène, born in 1924 was responsible for bringing geese to the market in Parthenay when she was about age 10 or 12 . She travelled this distance of some $8 \mathrm{~km}$ on her own, with horse and cart. Suffering from rheumatoid arthritis, Irène sat on a thick quilt. 
In 1939 Ernest and Noémie Sénéchaud left the farm at Le four to take up a farm in the commune of La Caquetière, near St. Martin du Fouilloux, some $12 \mathrm{~km}$ south of La Peyratte. They had been renting the farm in the commune of La Peyratte. When the owners wanted to sell the property, they were obliged to give their tenants the first option to buy. The price was high, at 109000 Anciens Francs, for this 30hectare (45 acre) property. They would regret their decision, as the good yields of the following years would have allowed them to pay off the loan. Instead, they moved to a larger 50-hectare farm in the commune of La Caquetière. As with their previous farm, they had cattle and grew various crops (cereals, legumes), and had various foul (hens, turkey, Guinea fowl) as well as rabbits and pigs in the farmyard. There was flowing water and a pond with edible fish (carp, tench, roach and perch).

In 1944, at the age of 60, Ernest died following an accident with a horse while working in the field. During the war, his work horse had died, and Ernest did not have the means to purchase another horse that could do field work. He tried to train his only other horse that had previously only been used to pull the wagon to the market. This other horse was nervous and not adapted for field work, but since it was war-time, there was no other choice. While trying to hitch the horse to a plough, Ernest was kicked in the abdomen. With the lack of medical services during the German occupation, he died of this accident on 28 March 1944. Their son Raymond continued to operate the farm at La Caquetière. Noémie lived to age of 82, passing on 13 August 1973 at Thénezay.

Among the 15 children of Ernest and Noémie, the four who died at young ages were: Roger born in 1914 at Beaulieu and died at two weeks of age; Marc and Marcelle, twins, born in 1921 at La Peyratte, Marcelle died after five days and Marc at 13 months; and a stillborn child born in 1933 at La Peyratte. The 11 children who lived to adult ages were all married (see Appendix 3.2):

- Albert and Aimée (née Pain) Sénéchaud were married on 6 February 1937 at Lhoumois, FR. They operated the farm attached to the chateau de La Rochefaton near Lhoumois $(20 \mathrm{~km}$ from Parthenay). Albert and Aimée had nine children: Yves, Monique, Maurice, Réjeanne, Robert, James, Bernard, Moisette, Gilbert.

- Suzanne and Marcel Ingremeau lived at Saint Martin du Fouilloux (close to La Chapelle-Bertrand, $13 \mathrm{~km}$ from Parthenay) where they were they operated La ferme de la Simnaudière. They did not have children.

- Alice and Nestor Martin were married at Saint Martin du Fouilloux. They had a grocery store at Thénezay (23 km from Parthenay) and had one child: Michel.

- Raymond and Marthe (née Guillot) Sénéchaud were married in 1944 at Saint Martin du Fouilloux. They continued on the farm of Raymond's parents at Saint Martin du Fouilloux (13 km from Parthenay) and later retired in Parthenay. The farm did not stay in the family into the next generation. Raymond and Marthe had nine children: Micheline, Claude, René, Ginette, Francis, Joël, Danielle, Madelaine, Marie Line.

- Gisèle married a person with the last name of Martin and had one child: Mauricette. Mr. Martin was a farm worker on the farm of Gisèle's parents. He then went to war and never returned. Gisèle then married Raymond Chambon at Saint Martin du Fouilloux. They lived in Thénezay where Raymond worked with zinc and lead for the construction of eavestroughs and 
plumbing (artisan plombier zingueur). They had one child, Gilles; Mauricette took the name of her adoptive father.

- Fernand and Louisette (née Thibault) Sénéchaud were married on 20 June 1959 in Thénezay. They lived in La Boissière (the lieu-dit of a hamlet next to Thénezay) and retired in Thénezay. Fernand worked in masonry. They did not have children.

- Irène and Armand Robert were married on 16 February 1946 in Thénezay. They lived in Thénezay where Armand worked as an assistant to a wine merchant. They had six children: Christian, Christiane, Jean-Michel, Colette, Jacques, Isabelle.

- Louis and Paulette (née Groleau) Sénéchaud were married at Saint Martin du Fouilloux. They lived in Beaulieu-sous-Parthenay (9 km from Parthenay) where Louis was a farm worker. They had nine children: Jacky, Jean-Paul, Eric, Philippe, Patrice, Claudie, Beatrice, Chantal, Annie.

- Rémy and Régina (née David) Sénéchaud were married on 27 September 1952 in Chaladray. They lived in Chalandray (20 km from Parthenay) and retired in Thénezay. Rémy was employed by an agricultural cooperative that produced silage and managed cereal stocks brought by farmers (in French: employé dans une cooperative agricole chargé de l'ensilage et de la gestion des stocks de céréales apportés par les agriculteurs). They had three children: Catherine, Françoise, Thierry.

- Henriette and Paul Molton were married on 13 January 1951 in Thénezay. They lived in Thénezay then Parthenay where Paul worked for the department that looked after roads (Service d'état de l'équipement, previously called "les Ponts et Chaussées"). They had two children: Dominique, Jocelyn.

- Gilbert and Ginette (née Fillon) Sénéchaud lived in Niort (45 km from Parthenay) where Gilbert worked in an insurance company. In 1956, he had been in the Algerian war for seven months where he caught lung congestion and received a military pension. They had six children: Pascal, Serge, Bruno, Dany, Yanic, Parni.

The children of Ernest and Noémie Sénéchaud all lived in the Departement of Deux-Sèvres, or in the adjoining Departement of Vienne (Chalandray). It is noteworthy that Albert, Raymond and Louis each had nine children, as did their first cousin Leon Beaujot. Altogether, Ernest and Noémie Sénéchaud had 15 children born between 1912 and 1933, and 47 grandchildren.

The third child of Louis and Justine Sénéchaud was Léon Henri Sénéchaud, born on 25 October 1884. We have lost contact with this family. We understand through Alice Martin (daughter of Ernest and Noémie Sénéchaud, see above) that Léon and Marceline Sénéchaud lived in Exireuil, near Saint-Maixent-l'École, $28 \mathrm{~km}$ south of Parthenay. They had four children, with the first two named Madeleine and Roger.

The fourth child of Louis and Justine Sénéchaud was Bertheline, born on 4 October 1885. Married on 14 June 1910 in Saint Hubert, the story of Bertheline and Félicien Beaujot is told in the following chapter. They had three children born between 1911 and 1919, and 17 grandchildren born between 1933 and 1965 (see Appendix B): 
- Flora (née Beaujot) and Joseph Driscoll were married on 20 October 1931 in Forget, Sask. They were farmers at Handsworth then retired to Kipling. They had six children: Bertha, Joseph, Monica, Jack, Leon and Bernice.

- Albert Beaujot married Grace Beaulac on 15 May 1975 in Calgary, Alta. Albert was a carpenter first at Saint Hubert then in Calgary. They had two children: Alan Pelletier and Leonard Pelletier.

- Leon and Dorothy (née Mullie) Beaujot were married on 14 July 1945 at Saint Hubert. They were farmers at Langbank and retired in Kipling. They had nine children: Roderic, Norbert, Fred, Honory, Leona, Doreen, Adelin, Patrick, and Jeanette.

The fifth child of Louis and Justine Sénéchaud was Marcel Sénéchaud, born on 16 April 1888 and married Alice née Brunet on 22 September 1915 at La Ferrière en Parthenay. We do not know if Marcel and Alice Sénéchaud had children. The sixth and last child was Octavie Sénéchaud, born on 2 March 1890 and dying three days later on 5 March 1890, both at La Chapelle-Bertrand.

\section{Reconnecting across the Atlantic: The Sénéchaud side}

Four decades would elapse between Bertheline's trans-Atlantic trip in 1910 and the next crossing made by her son Albert Beaujot in 1951-52. As a 40-year-old single man living with his mother, Albert spent several months visiting the Sénéchaud family. He would have met his aunt Radégonde and Honoré Largeau, and several members of her family. André (called Dédé) Largeau remembered that, at age 17, he accompanied Albert on a trip to Germany to see Bernadette (dite Marguerite) and Clovis Gagnères, where Clovis was part of the post-war occupation.

Jocelyn Molton remembers his parents (Henriette and Paul Molton) talking about the visit because Paul was a painter and Albert was a carpenter. At the time of her $90^{\text {th }}$ anniversary in 2019, Henriette and Paul Molton were remembering that their Aunt Bertheline had wanted her son Albert to convince a Sénéchaud cousin to emigrate to Canada, but no one decided to follow Albert back to Canada. Albert had left little souvenirs such as a touristy Indian dagger and pennants with felt flags of the Canadian provinces.

Gilbert Sénéchaud also remembered talking with Albert about carpentry in Canada and being surprised to hear that the frame of a roof would be assembled on the ground then lifted onto the house. Christian Robert (son of Irène and Armand Robert) remembers that he was 6 or 7 when he went on a rabbit hunt with his father and Albert Beaujot.

In 1976, Leon and Dorothy Beaujot, along with Flora Driscoll, visited the Largeau and Sénéchaud families. They spent most of their time with Raymond and Germaine Largeau in Saumur, but they also visited André (Dédé) and Liliane Largeau in Parthenay, and Albert and Aimée Sénéchaud in Lhoumois (where Alice and Nestor Martin were also present). Then in 1978, Raymond and Germaine Largeau, along with their children Denis and Anne, visited the families in Saint Hubert (Leon and Dorothy Beaujot) and Calgary (Albert Beaujot and Grace Pelletier, Flora Driscoll). Albert Beaujot and his son Leonard 
Pelletier made another trip in 1979. Germaine was back in Canada in 1993, with her granddaughter Marion Ménage, and Leon and Dorothy were in France in 1994.

There was a daily reminder of the Sénéchaud family in the home of Leon and Dorothy Beaujot. At every meal, rather than setting teaspoons for each person, these spoons were in a spoon holder which was placed in the middle of the table. This glass container, ideal for teaspoons in a large family, had been inherited from Bertheline, and the tradition continues with its presence on the table of her granddaughter Leona and Russell Fry.

In these next generations, there was a 1994 visit from Trevor and Michael Driscoll, grandsons of Flora, and a 2001 visit by Bertha and Catherine Holmes, daughter and granddaughter of Flora. In January to June 2001, Camille Fry, daughter of Leona and Russell Fry, was with the Largeau family as a Grade 10 exchange student. In June and July 2012, Anne and Yannick Courjault, with their children Oriane, Maxime and Juline were visiting in Abbotsford, Penticton, 100 Mile House and Calgary. In 2014, Doreen Gardner and Adelin Warje were guests at the wedding of Justine Largeau, daughter of Denis and Agnès Largeau.

In 2004, Jocelyn Molton looked up the Beaujot name in the international telephone directory, trying to re-establish contact with his Canadian cousins. One of the first phone numbers he called was that of Leon and Dorothy Beaujot in Kipling. Dorothy was surprised at how well Leon could speak in French. Following on this contact, Roderic Beaujot continued the exchange, including visits in 2005 and 2015. It was through Jocelyn Molton that we first learned all the names and dates of birth of the children of Ernest and Noémie Sénéchaud. At the time of Leon Beaujot's $90^{\text {th }}$ birthday in 2009, he had seven surviving first cousins, children of Ernest and Noémie: Alice Martin, Gisèle Chambon, Fernand Sénéchaud, Rémi Sénéchaud, Louis Sénéchaud, Henriette Molton and Gilbert Sénéchaud. With his son's help, Leon talked over the phone with Gilbert Sénéchaud and Alice Martin.

During the 2015 visit of Roderic and Elisabeth Beaujot, Maryvonne (and Jean-Yves) Ménage, and Anne (and Yannick) Courjault invited us to lunch at the Château de Saumur. Juline Courjault and Martin Ménage, with his partner Myriam Bichindaritz, were part of the group. We also visited the cemetery where their parents Raymond and Germaine Largeau, as well as their aunt Marguerite and Clovis Gagnères, are buried. Afterwards, we stayed at Le Grand Logis Hotel in Parthenay, visiting with family and travelling in the region. A block from our hotel we saw Dédé and Lili Largeau and their son Jean François and Béatrice Largeau. Colette and Robert Rolland showed us around the Deux Sèvres district, including La Chapelle-Bertand, La Peyratte and Thénezay. Jocelyn Molton and Isabelle and Bruno Derose organized a private visit to Château de Saint-Loup at Saint-Loup sur Thouet, near Thouars. 


\section{Mullie}

Two substantial documents provide background on the Mullie family. In 1963, Jos. L.M. Mullie published Les Descendants de DESMULLIERS - DELFAILLE de Marcq-en-Baroeul (xxvi + 383 pp.). Written in Flemish and French, this genealogy covers 17 generations starting with Lotard Des Muliers, born circa 1435, landowner at Marcq-en-Baroeul. There is uncertainty regarding the first two generations, but in the third generation, Jehan Des Mulliers (1528-1590) married Marie Delfaille (d. 1608) and they had five children born at Marcq-en-Baroeul (thus these names in the title of the book). This town is in northern France, $5 \mathrm{~km}$ from Lille. The area was once part of the Netherlands until it was absorbed into France by the 2 May 1668 Peace of Aix-la-Chapelle, after the 1667 invasion by Louis XIV (Mullie, 1963: xxiv). It is 20 $\mathrm{km}$ from Ploegsteert, in what is now Belgium.

In 2016, Jean Mullie published Histoire et généalogie de la famille Mullie et de ses alliances which carries forward from the family of Jean Louis Mullie (1845-1919) and Félicie Julie Marie née Delannoy (18491940), to include their 444 descendants as of 31 December 2015 (Mullie, 2016: 256). Louis and Félicie Mullie were married on 5 September 1876 in Messines and their eight children were born at Ploegsteert between 1877 and 1892. Their third child is Paul Mullie, father of Dorothy Beaujot.

This family of Louis and Félicie Mullie are the $11^{\text {th }}$ entry in Generation XII of the earlier book (Mullie, 1963: 194). Since there are a total of 125 entries in the XII ${ }^{\text {th }}$ generation, the second book includes only a small part of the earlier work (see Mullie, 1963: 241-243, 302-308 and 353). The second book does list the direct ancestors of Louis and Félicie Mullie going back 11 generations (Mullie, 2016: 18-42, 258-261).

Unlike other genealogies, Jean Mullie's (2016) book includes pictures of individuals and families as well as select life histories. The term "alliances" is well chosen in the title, since the book carries details on the family origins of spouses of descendants, including the names of their parents. The index carries some 1000 names, with the names of descendants shown in bold print. The book is organized around seven branches corresponding to the seven married children of Louis and Félicie Mullie (Mullie, 2016: 9, 256, 261-290). Two of the branches are in Belgium, two in France, two in Canada and one in Belgium and France. Jean Mullie was uniquely situated to write this book, being the only person in the generation of 30 first cousins to have met all of his uncles and aunts. He also met all 27 in the generation of first cousins who lived to adult ages. As he did through various means throughout his life, Jean's book brings together the Mullie descendants and their families over geography and generations.

As one of the two survivors in the generation of first cousins, Jean Mullie (2019) has published an update of his 2016 book under the title Historie et généalogie de la famille Mullie depuis 1435. With a cut-off of 31 December 2018, this second edition has 479 descendants of Jean Louis Mullie and Félicie Julie Marie née Delannoy. There are also new pictures and stories, an amazing undertaking for someone who is in his $91^{\text {st }}$ year. 


\section{The family of origin of Paul Mullie}

Jean Louis Mullie was born in Sint Deijs (Saint-Genois, Belgium) on 31 July 1845, and Félicie Julie Marie Delannoy was born in Mesen (Messines, Belgium) on 20 August 1849. Married on 5 September 1876 in Mesen, they lived on and operated a farm at Ploegsteert which is on the border with France $15 \mathrm{~km}$ from Mesen and $20 \mathrm{~km}$ from Lille, France). The town was called Ploegsteert because a plough furrow was originally used to mark the boundary between France and Belgium. The exact location of their farm is now 9 Chemin de la Blanche 7784 Comines-Warneton, $2.9 \mathrm{~km}$ from the centre of Ploegsteert. The farm is on the south side of Chemin de la Blanche, the last buildings before Highway N58. They rented this farm and had help from other agricultural workers besides the family. Louis Mullie was also churchwarden (marguiller) at the church of Saint-Pierre and Saint-Paul, and administrator for the parish. He was also President of the Société de Secours Mutuels (mutual help society) of the Commune of Ploegsteert, and he was decorated with the "Croix Civique de Première Classe et de la Médaille Commémorative du règne de S.M. Léopold II" (Mullie, 2016: 42; 2019: 46).

Their eight children were born at Ploegsteert, between 1877 and 1892. In 1905, when Louis was 60 and Félicie was 56, the children were aged 13 to 28 , all single and mostly living at Ploegsteert. By the time of the German invasion of Belgium (3 August, 1914), four of the children were married and no longer living with their parents. Marthe married Pierre Devos on 20 June 1905. They lived at Ploegsteert where their three children were born (1908-1913) and where Pierre would die during the war, on 14 April 1915. Raymond had married Alide née Joyé on 28 April 1906. They occupied the farm of Alide's parents at Wijtschate, $7 \mathrm{~km}$ north of Ploegsteert, where their three children were also born (1907-1909). Bertha married Valère Domicent on 16 June 1908 and they were living at Warneton, 6 km northeast of Ploegsteert when their first two children were born $(1909,1911)$. Paul married Julienne née Smets on 19 July 1910 and they went to Canada the following year. At age 30, Julien left from Antwerp on the SS Lapland, arriving at Ellis Island, New York, on 2 April 1913, then travelling on to his brother's farm in Saskatchewan.

The farm at Ploegsteert was right on the line of the "no man's land" between the battling armies of the Great War. The British troops occupied the Mullie property and they could see the German line, about one km away, from the rooftop of the house. It was at Ploegsteert Wood, just north of the Mullie and Duthoit farms, that the 1914 Christmas truce occurred: the troops joined across enemy lines for a soccer game, singing and midnight mass. The 2005 French film "Joyeux Noël," directed by Christian Carion, with actors Diane Kruger, Benno Fürmann and Dany Boon, enacts these events of the first Christmas of the war (Mullie, 2016: 180; 2019: 206). In early 1916, Winston Churchill, then Lieutenant-Colonel with the $6^{\text {th }}$ Battalion Royal Scots Fusiliers, was stationed for a while on what became the southern flank of the Ypres Salient. Churchill referred to the town as "Plugstreet" since the British could not pronounce the Flemish name. Nearby Wytschate became "White Sheets." There is a plaque of Churchill in Ploegsteert.

At the outbreak of the war, Louis and Félicie, with their three remaining children, were on the farm. Emile was called into the Belgian military in 1915, leaving Maurice aged 28 and Emma aged 22. The parents and their married son and two married daughters escaped as refugees to Cany-Barville, France, 
$200 \mathrm{~km}$ from Ploegsteert. This included the widowed Marthe Devos and her three children aged two to seven. The third child (Freddy) of Berta and Valère Domicent would be born at Cany-Barville, in 1917. As a Belgian military veterinarian, Valère had been stationed in this region to service the horses of the military. The three children of Raymond and Alide went to school at Cany-Barville. Maurice and Emma stayed on the farm at Ploegsteert to salvage what they could. In 1917, Emma, then finally Maurice joined the parents at Cany-Barville where the father would die on 2 April 1919. In the meantime, the farm at Ploegsteert was completely destroyed. At the time of his death in 1919, at age 73, Louis Mullie had 13 grandchildren from his four married children.

At the end of the Great War, 11 November 1918, Louis and Félicie Mullie were in Cany-Barville, France, with five of their children: Raymond and Alide and their three children, Marthe Devos and her three young children, Bertha and Valère Domicent and their three children, Maurice and Emma. Paul and Julien were in Canada. On 10 May 1919, shortly after his father's death, Maurice married Cecile de la Brosse at Cany-Barville. Maurice and Cécile remained in the area, first at Auzebosc where their first four children were born (1920-1924) then at Les Loges where their three other children were born (19261932).

After the war, Raymond and his family returned to their farm at Wijtschate (7 km from Ploegsteert). Other than Maurice who stayed in France, the rest of the family at Cany-Barville returned to Warneton ( $6 \mathrm{~km}$ from the farm at Ploegsteert), where Bertha and Valère Domicent had lived before the war: Félicie Mullie and her daughters Emma Mullie, Bertha Domicent and Marthe Devos, with their six children. Jean Mullie notes that his uncle Valère Domicent, veterinarian, played a large role in keeping the family together, first at Cany-Barville, then at Warneton.

After being discharged from the military, Emile came back to the farm at Ploegsteert where he received government payments to bring the farm back into operation. Nothing was left but a bell that had been used to call the workers in for meals. The farm site at 9 Chemin de la Blanche ( 7784 Comines-Warneton or 7782 Ploegsteert) was rebuilt to the west of the buildings that had been there before the war. It is likely that a tree in the existing enclosure dates back to the early 1920s.

Julien returned from Canada to marry Marie-Louise Duthoit, a neighbor from Ploegsteert, on 11 February 1924, in Bailleul, 59270 France. They moved to Canada with the two-year-old daughter (Jeanne Leconte) of Marie-Louise, whose husband (Jean Baptiste Leconte) had died from exposure to mustard gas during the war. They left for Canada on 28 February 1924. Julien and Marie-Louise would have five children born at Arborfield, Saskatchewan, between 1924 and 1931.

After his marriage to Clémence Lutun on 10 February 1925, Emile continued to work on the farm at Ploegsteert and their four children were born there between 1926 and 1932. In 1932, Emile and Clémence left Ploegsteert to a farm near Foncquevillers, France (75 km from Ploegsteert).

Félicie Mullie died at age 90, on 3 August 1940, at Warneton. At that time, all eight of her children were living, her 30 grandchildren had been born between 1907 and 1932, and three had died (Elisabeth, 
daughter of Maurice, died at birth in 1932; Lucie, daughter of Emile, died of tuberculosis at age 10 in 1939; and Jean Mullie, son of Paul, died of appendicitis at age 16 in 1929). Louis and Félicie Mullie would eventually have 90 great-grandchildren and 183 in the next generation (Mullie, 2016: 256).

\section{The children of Louis and Félicie Mullie}

Louis and Félicie Mullie had eight children all born in Ploegsteert, Belgium. All eight survived to adult ages, seven were married and had children.

The first to marry was Marthe Mullie, on 20 June 1905, at the age of 26. Marthe and Pierre Devos lived in the town of Ploegsteert, Belgium, where Pierre was Municipal Secretary and Agricultural Engineer. Their three children were born at Ploegsteert: Marie-Aimée in 1908, Rosa in 1910 and Paul (called Pierre) in 1913 (see Appendix 3.3). At the young age of 41, Pierre died at Ploegsteert on 14 April 1915. Marthe followed her parents as refugees in France during the war, and back to Warneton after the war, where she would die on 8 March 1968. Marthe and Pierre Devos had three children, six grandchildren and 11 great-grandchildren.

The second to marry was Raymond Mullie, at the age of 28, on 28 April 1906, to Alida Joyé. They were farmers at Wijtschate on the farm of Alida's parents ( $9 \mathrm{~km}$ from the farm of Raymond's at Ploegsteert). The farm at Wijtschate was about 43 hectares, on which they produced wheat, beets, oats, rye and flax. They regularly employed three men, and occasionally women as needed. The farm had five horses. Raymond was also President of Church Construction (Fabrique l'Église) and member of the various brotherhoods (confréries) of the parish. Raymond and Alida Mullie had three children: Louis in 1907, Jeanne in 1908 and Paul in 1909. After the war, the family could have remained in France, but they returned to Belgium, where the Catholic religion was better accepted and protected. When the family came back from Cany-Barville, Raymond, with his sons Louis and Paul were paid by the government to fill the bombing holes on their farm. The middle child, Jeanne, lost an arm when picking something up that turned out to be a bomb. Louis and Paul worked with their father. In 1944, after his marriage with Marie-Henriette Windels, Paul took a farm in the commune of Pottes, where his wife had been born. Louis married Marie-Aimée Six in 1945. He continued to operate the Wijtschate farm with his father, until Raymond's death in 1951, then alone. In the late 1940s or early 1950s, they purchased a Mann tractor. In 1955, Marie-Aimée became seriously ill and they left the farm to live in Warcoing, where Marie-Aimée died in 1957, at the age of 48.

Raymond's spouse Alida had died at age 51 on 12 February 1932, and Raymond at age 74, on 24 July 1951, at Wijtschate. Besides their three children, Raymond and Alida would have 4 grandchildren and 16 great-grandchildren.

At age 22, Bertha Mullie married Valère Domicent on 16 June 1908. Except for their exile in France in 1917-19, Bertha and Valère lived at Warneton ( $6 \mathrm{~km}$ from the parental farm at Ploegsteert) where Valère was a rural veterinarian. Bertha and Valère Domicent had three children: Roger in 1909, Wilfrid 
in 1911 and Freddy in 1917. Valère died at age 79 on 31 March 1958 and Bertha, also at age 79, on 18 November 1965. Besides their three children, they had 10 grandchildren and 21 great-grandchildren.

Paul Mullie, at age 29, married Julienne Smets on 19 July 1910. In 1905, Paul had received the degree of Engineer in Agronomic Sciences from the Catholic University of Louvain. The address on his student card is shown as Ploegsteert. The university records also indicate that Paul subsequently worked in two places before leaving for Canada. He was "chef de culture" managing the agricultural operations of a reform school for delinquent youth. This school was called École de Ruiselede (now called De Zande) with the mission of education in agriculture. Paul also managed the agricultural lands of the Count of Marnix, surrounding the castle at Overijse, east of Brussels. On the wedding certificate, Paul is indicated as régisseur (manager) at Wingene, where the reform school was located. Paul and Julienne were on the SS Canada (White Star / Dominion Line), leaving Liverpool on 4 March 1911 and arriving in Halifax on 12 March 1911, ten weeks before their first child was born on 2 June 1911 (see "Paul Mullie" under immigration/passenger lists at www.familysearch.com). Paul and Julienne Mullie were farmers at Saint Hubert, Saskatchewan, where their five children were born: Marie-Louise in 1911, Jean in 1913, Raymond in 1915, Dorothy in 1917 and Michel in 1920. Jean died of appendicitis at age 16. Knowing about the war affecting his relatives in Europe, Michel volunteered for overseas military service in 1941, but was ill with the mumps when his comrades left for England.

The family of Paul and Julienne farmed 560 acres of land and the farm remains in the family into the third generation. The next chapter gives a longer account of their lives (see also Mullie, 2016: 80-83). All four of their remaining children were farmers: Raymond and Maria Mullie on the parental farm; Dorothy and Leon Beaujot on an adjacent farm; Michel and Jeanne Mullie at Arborfield; and Marie Louise and Philippe Laforge at Zenon Park.

Julienne died at age 81 on 12 November 1959 at Whitewood where they had retired, and Paul at age 86 on 9 June 1967, at Saint Hubert. Besides their 5 children, they had 28 grandchildren and 53 greatgrandchildren.

At age 33, Maurice Mullie married Cécile de la Brosse on 10 May 1919. Cécile was born at Cany-Barville, France, where various members of the Mullie family were refugees during the war of 1914-18. Maurice had worked on the large farm of Cécile Lange at Beuzeville la Guerard (76), where there were more than 100 Normandy milk cows. After their marriage, Maurice and Cécile Mullie took a lease on the farm of the Château d'Auzebosc (76) near Yvetot, where their four oldest children were born: Bernard in 1920, Marie-José in 1921, Robert in 1923, and Marie-Louise in 1924. In 1925, they bought a farm (La Ferme de la Forêt) in the commune of Les Loges. The three other children were born on this farm: Marcel in 1926, Jean in 1929 and Elisabeth in 1932. Without medical assistance following an obstructed birth (accouchement dystocique), Elisabeth died at birth on 6 January 1932. Besides their seven children, Maurice and Cécile Mullie would eventually have 11 grandchildren and 15 great-grandchildren.

Their farm was very isolated, with poor roads. At first, the house only had rudimentary facilities: no running water, a cistern and outdoor toilets ("les tinettes comme on disait"). They also suffered during 
the depression years of 1929-32 when the poor markets forced the farmers to accumulate as much as three years of unsold crops in the granaries (Mullie, 2016: 179-182). Maurice had originally purchased 80 hectares but in 1937 he was forced to sell 30 hectares. He increasingly focused on milk cows and in 1936 he was one of the first to register with the milk control board, with eventually 20 cows producing 15 liters of milk per cow per day. He cultivated clover and oats to feed the horses and cattle, as well as wheat, sugar beets and flax. They had hired help both on the farm and for household tasks. By 1940, it was Marcel's job to look after the five mares and three or four colts (Mullie, 2016: 195-197).

On 10 or 11 June 1940, a German air force plane went down near the farm. The crewmen discarded their uniforms and pretended to be English as they came to the Mullie farm for help in returning to their base. Robert had gone near the airplane and, seeing that it carried a swastika, he came running home to say that they should not collaborate. A German officer who could speak French took Bernard at gunpoint to bring them to the German front. Cécile was very worried that she might never see her son again. After a long and agonizing day, Bernard returned unharmed late the same night (Mullie, 1995).

Another war incident occurred in 1942 when a commando of 119 British parachutists came to destroy the German radar system at Bruneval. This location is $8 \mathrm{~km}$ south of Étretat and not far from the farm of Maurice Mullie, La ferme de la Forêt, Les Loges. The mission, taking place during the night of 27-28 August 1942, was successful. The losses were limited to two deaths, 7 injured and 6 prisoners. Two of the airmen were not able to make it to the returning embarkation. They were in hiding with a French couple at Étretat for over a year. During that time, Marie-Louise was among the people of the area who made very discreet bicycle trips to bring food to the parachutists. The French couple was apprehended as they attempted to bring the English parachutists to France Libre. The aviators were taken as prisoners of war. The French couple was deported to Germany. They later returned, much diminished. A memorial has since been built at this location, in the commune of Saint-Jouin-Bruneval (76280), to commemorate these events. Charles De Gaulle also came there after the liberation in 1947 to give an important speech.

Pierre Roland, who would become the spouse of Marie-Louise, was too young to be mobilized at age 18 in 1940. Nonetheless, he voluntarily joined the French army. With the German invasion, he was rapidly demobilized, but in 1942 he was among the more than 400,000 young French men born between 1920 and 1922 who were placed under order for Compulsory Work Service in Germany (STO: Service de Travail Obligatoire). He escaped instead to southern France and eventually to Spain but was later apprehended in Spain by the Franco regime. After a month in prison, he made his way to Morocco, joining the military operation that would liberate southern France in October 1944. He was demobilized as a sergeant (maréchal de logis) but he was coming back from five very difficult years in the prime of his life, with no advanced education and no work. Robert Mullie, who was in the seminary at the start of the war, escaped by hiding on the farm of his uncle Emile at Foncquevillers.

At the 6 June 1944 landing at Le Havre, a Scottish Lieutenant came to the farm to ask if they could accommodate some of the British soldiers who had taken part in the liberation. With Cécile's ability to speak English, Maurice and Cécile opened their last bottle of champagne and the family at La ferme de la Forêt welcomed ten officers who had taken part in the liberation. 
After their marriage in 1953, and with their parent's retirement, Marcel and Odile took over the farm. They started with 55 hectares and eventually expanded to 80 hectares. The first tractor was purchased in 1955. This was also the year that the cattle were affected by foot-and-mouth disease (fièvre aphteuse) which caused the cows to abort and produce very little milk. The raising of pigs was more profitable at this time, including a sow, named Violette, and 12 piglets that Odile had brought from her parent's farm. With good care, Violette produced a number of litters that increased their pork production. The 1960s brought much modernization: a first combine in 1960; the first milking machine in 1962; connection to the town water system in 1965; and a new barn and milking facilities in 1970-71. Their milk production was much improved as they grew corn to feed the cattle. Starting in 1965, the herd of Normandy cattle was replaced with the higher milk-producing Holsteins. The crops consisted of escourgeon wheat, flax and sugar beets, as well as both field-corn and silage-corn. They hired a salaried worker on a seasonal basis.

In 1986, when Dominique and Florence Mullie took over the farm, it consisted of 80 hectares and 35 Holstein cows with a milk quota of 270,000 liters per year. With further mechanization, by the mid1990s they no longer employed hired help. They continued the same grain production, building to 105 hectares with 100 milk cows, producing 30 liters per day, with an annual milk quota of 870,000 liters. In 2018, the farm was passed on to a fourth generation: their son Armand Mullie.

The next to marry was Julien Mullie, at age 41 . Having gone to Canada in 1913, Julien returned to Belgium to marry Marie-Louise Duthoit, on 11 February 1924. Emma, Julien's younger sister, had informed him that a neighbor in Ploegsteert had lost her husband, due to mustard gas exposure during the war. Marie-Louise had lived on the Duthoit farm at 23 Chemin de la Blanche, some 600 meters from the Mullie farm on the same road (on the east side of the Military Cemetery). This farm has remained much as it was in the 1920s, with buildings around an enclosure, including an outhouse. With her previous husband, Jean-Baptiste Leconte, Marie-Louise had had two children. Their son Jean Leconte, born on 4 February 1920, died of meningitis on 15 July 1921. Their daughter Jeanne Leconte, born on 12 March 1922, came to Canada with her mother and stepfather in 1924. According to records at the Red Star Museum in Antwerp, they were passengers on the Melita, leaving on 28 February 1924 for St. John, Canada.

After their marriage, Julien and Marie-Louise Mullie were farmers on the property where Julien had cleared the trees during his bachelor years. The town of Arborfield had developed after Julien's arrival, next to the farm that he had established. Arborfield is on the northern edge of the part of Saskatchewan that is suitable for agriculture. He had purchased a homestead (NW $1 / 4$ of 2-48-12- W $2^{\text {nd }}$ ) in 1914 and by 1948 they were farming a second homestead plus 3.5 other quarters for a total of 5.5 quarter sections (880 acres). The 1953-54 Permit Book for selling grain shows J. Mullie and sons (Alfred, Roland and Maurice/Felix) with a total of 1680 acres ( 8.5 quarters owned, and 2 quarters rented): 500 
acres of wheat, 570 of barley, 424 in summerfallow, 80 in other crops and 105 acres uncultivated. ${ }^{10}$ They had purchased a car in 1938 and their first Oliver Tractor in 1939. By 1954, they were using two caterpillar crawlers to pull equipment in the fields. In May 1954, when Julien was 71 and Marie-Louise was 62 , the land was passed on to the next generation. Their son Roland and Mary would grow a variety of registered seeds and specialize in Charolais cattle, including importing one of the first Maine-Anjou bulls from France.

Julien and Marie-Louise had 5 children, all born at Arborfield: Alfred in 1924, Roland in 1926, Maurice (known as Felix) in 1927, Gilbert in 1930 and Joseph in 1931. Julien died at age 99 on 7 March 1981 and Marie-Louise on the eve of her $98^{\text {th }}$ birthday, on 17 March 1990 (Mullie, 2016: 131-135). From these 5 children, Julien and Marie-Louise Mullie would have 14 grandchildren and 23 great-grandchildren.

The last to marry was Emile Mullie, at age 34, to Clémence Lutun on 10 February 1925. When his older brothers were either in Canada or beyond the age to be called for military service, Emile was drafted into the Belgian army in 1915. Serving on the artillery, including 26 months of trench warfare, Emile received various military decorations: Croix de guerre 1914-1918 avec Palme; Médaille Commémorative 1914-1918; Médaille de la Victoire; Médaille du feu avec étoile de bronze (Mullie, 2016: 217-220).

On release from military service, and with the help of government assistance, Emile took on the horrendous task of clearing the Mullie farm at Ploegsteert that had been destroyed during the war. The land was riddled with trenches and strewn with shrapnel and other remnants of military equipment. The land was also flooded. Living in half-moon barracks, and using shovels and spades, ditches had to be made to drain the water. It was only in 1921 that a first small crop could be produced, between the shell holes. Farm animals had been requisitioned from Germany because of the war damage, but shelters had to be built for the cattle, cows, pigs and poultry.

After their marriage in 1925, Emile and Clémence Mullie had four children, all born at Ploegsteert: Thérèse in 1926, Pierre in 1928, Lucie in 1929, and Henri in 1932. According to the recollection of Gaston Duthoit (2014), a neighboring farmer, this farm was about 35 to 40 hectares. They used four horses to produce wheat, sugar beets and dried green peas. There were four milk cows, cattle, chickens, and hens for eggs. Barley was also grown to feed the horses and cattle. The garden produced enough vegetables and fruit that these did not need to be purchased.

In 1932, the young family moved to Foncquevillers, France, where they had bought La Ferme de la Haye. They first had to rebuild the house and other buildings that had been completely destroyed during the Great War. They settled at La Ferme de la Haye with the parents of Clémence who had been demoralized by the War, having lost their only son Pierre Lutun at 20 years of age, on 6 September 1916. The family would suffer further hardships. On 28 November 1939, Lucie, the third child of Emile

\footnotetext{
${ }^{10}$ Marchildon (1989: 120) gives this same figure of 1680 acres in referring to her son-in-law, Alfred Mullie who was farming with his father at this time.
} 
and Clémence, died of tuberculosis at 10 years of age. Her death was probably precipitated by the lack of medical services during the War.

At the outset of World War II, Pierre had been a student with Les Frères des Écoles Chrétiennes at Ecluse ("Sluis" in Dutch), $20 \mathrm{~km}$ from Bruges, when the school closed due to the war. Leaving France because of the Combe Law of 1905 which separated church and state, the Frères des Écoles Chrétiennes had opened a school for French boys in The Netherlands, fearing that similar anti-religious movements would appear in Belgium. Making his way back home at the age of 8 , Pierre was then enrolled at the Petit Séminaire d'Arras. On about 5 or 6 May 1940, bombs were falling on Arras where Pierre was in residence (pensionnat). His mother managed to bring him home just before the classroom where he was attending Grade 6 was completely destroyed. Later, the farm was subject to artillery fire across enemy lines (Mullie, 2016: 234-238). Countless empty gun shells have since been collected and the older buildings remain marked by bullet holes.

The post-war period brought new hopes and prosperity to La Ferme de la Haye, which remains in the family into the third generation, with Christophe Mullie following his father Pierre and grandfather Emile. Thérèse, the oldest of the children of Emile and Clémence Mullie, with her spouse André Lanthiez, had a dairy farm near Saint Quentin, France, and in 1952 they bought the farm called Le Château Vert at Hondainville, France. Chateau Vert, once owned by one of Napoleon's soldiers, is 100 hectares completely enclosed by a stone wall, with a four-story manor house. They grew crops and raised cattle, pigs and poultry. Later they sold sand and gravel from the property. This removal created small ponds where fish were introduced for tourists interested in fishing (Mullie, 2019: 254).

Besides their 4 children, Emile and Clémence Mullie would have 17 grandchildren and 44 greatgrandchildren.

Born at Ploegsteert on 29 February 1892, Emma Mullie was the last of the children of Louis and Félicie Mullie. She was with the family as refugees at Cany-Barville in 1917-19 and returned to Warneton with her mother in 1919. In about 1959, having received good returns on a Congolese investment, Emma gave money to each of the families of her nieces and nephews. Jean Mullie recounted how his Aunt Emma sent him some money when she heard that he had made a presentation on the Canadian Mullie families on return from his 1967 visit to Canada. Telling this story to the Canadian cousins who had come for his $85^{\text {th }}$ birthday celebrations brought a tear to Jean's eyes. Emma Mullie died at age 70, on 27 June 1970. She is remembered as very generous toward her family and "aunt par excellence": Tante Emma.

The five sons of Louis and Félicie Mullie would all be farmers and each of these farms passed into the next generation, with three of them passing to at least a third generation. In genealogical order: Raymond's farm was passed to Louis, Paul's to Raymond then Edward, Julien's to Roland, Maurice to Marcel then Dominique and now Armand, and Emile to Pierre then Christophe. 


\section{Reconnecting across the Atlantic: The Mullie side}

After the 1924 transatlantic trip of Julien and Marie-Louise Mullie, with her two-year old daughter Jeanne Leconte, almost three decades would elapse before the next trip between Canada and Europe in the Mullie family. In June 1953, it was again Julien and Marie-Louise who came back to visit their European relatives. They travelled by train to Montreal and flew by prop airplane with stopovers in Gander (Newfoundland), Shannon (Ireland) and Paris for refueling. Julien was walking with a cane due to his dislocated hip. Paul and Julienne had wanted to take part of this trip, but they decided against for health reasons. Paul was also a much more cautious person than his adventuresome brother.

Earlier trips had brought together the Mullie families who were living in Belgium and France. Jean Mullie remembers the $250 \mathrm{~km}$ trip from Les Loges, France, to Warneton, Belgium, in 1939, with his parents and their 6 children aged 10 to 19, packed into a Citroën familiale, with Bernard as the driver. For Jean, who was 10 at the time, it was the discovery of his family: grandmother Félicie, aunts Bertha (and Valère) Domicent, Marthe Devos, and Emma, and the first cousins of his generation. On route, they stopped at Foncquevillers to see Uncle Emile and family.

A similar trip is remembered between Saint Hubert and Arborfield, a distance of $390 \mathrm{~km}$. After harvest, in 1937, Paul and Julienne Mullie travelled with their 4 children aged 17 to 26 to visit the family in Arborfield. The trip took all day, travelling at not much more than 30 miles per hour, squished into a Model A Ford. Once again, it was the adult children who drove. It is remembered that, during this visit, Paul and Julien were showing off the car in Arborfield when Julien jumped out to greet a neighbor, forgetting to first stop the car. He was used to horses who could read the driver's mind. This trip was fruitful because two of Paul and Julienne's children would eventually marry spouses from Arborfield, bringing many more trips over the generations.

In the next generation, the first transatlantic trip was by Jean and Nicole Mullie, in May 1967. As a veterinarian, and very interested in farming, Jean recorded conversations with the Mullie farming families of Saskatchewan as he sought to understand their farming practices. ${ }^{11}$ Jean was able to meet his uncles Paul Mullie, and Julien Mullie, thus being the only one of his generation to know all of his uncles and aunts, just a month before Paul Mullie's death. There were several other trips in the direction of Canada. Besides Saint Hubert and Arborfield, these trips mostly involved stops in Penetang, Ontario and Montreal, where Julien's sons Alfred, Gilbert and Joseph lived. Roger and Marguerite Domicent came to Montreal in 1969 where their daughter Chantal was spending six months. Besides visiting the families of Gilbert, Alfred and Joseph Mullie, they visited the families in Arborfield and Saint Hubert, then in about 1972/73, Marguerite came a second time with her son Yves. In 1978, Paul and Henriette Mullie visited while their daughter Marguerite Denoël and family who were spending a year in Montreal. Father Robert Mullie with his nephew Pierre Mullie made an extended trip across the country in 1980. MarieLouise and Pierre Roland visited the Mullie families in Ontario and Montreal in the fall of 1989. Henri and Renée Mullie visited in Montreal in 1981 and 1988. The two couples Pierre and Thérèse Mullie and

\footnotetext{
${ }^{11}$ These audio cassette recordings are being transferred so that they can be heard on $21^{\text {st }}$ Century devices.
} 
Thérèse and André Lanthiez travelled together in June 1992, visiting their Canadian first cousins in Montreal, Ontario and Saskatchewan. At the age of 75, having operated a small farm and served for 30 years as mayor at Saint Jean de Folleville, Bernard Mullie visited in July 1995 . This included the $50^{\text {th }}$ anniversary of Dorothy and Leon Beaujot, celebrated at Round Lake, Saskatchewan.

This generation of first cousins also made several trips to visit the Mullie family in Europe: Joseph Mullie visited in 1970; Leon and Dorothy Beaujot in 1976; Gilbert and Ruth Mullie in 1979; and Marie Louise Laforge with her daughter Irène in 1981; and Alfred Mullie with his son Marc in 1984. Michael and Jeanne Mullie made several trips which also included visits with Jeanne's first cousins on the Duthoit side: 1974, 1982, 1983, 1992 (attending the wedding of Hervé and Natalie Roland), 1997 and 2001 (these later three visits included Annette and Andrew Gunn and family from England). The visits from the Canadian Mullie families often included a stay in the Paris hotels, owned by Henri and Renée Mullie (Hôtel Victor Hugo and L'Ambassade) as well as visits to the farms of Emile Mullie (La Haye, Foncquevillers, France), Maurice Mullie (Ferme de la Forêt, Les Loges, France) and Thérèse and André Lanthiez (Chateau Vert, Hondainville, France).

Several Canadians in the generation of second cousins have visited in the French and Belgian Mullie families over the years. Already mentioned are Irene Laforge (1981), Marc Mullie (1984) and Annette and Andrew Gunn (1992, 1997, 2001). Armand Mullie made an extensive visit in 1969 on his way to Asia and around the world, and again in 1972 after he and Marlene were married. When visiting in 1969 on the farm of Marcel Mullie, Armand had impressed 12-year-old Dominique to the point that, 24 years later, he would name his own son Armand. Cyril Laforge visited in the European Mullie families in 1973 with Jean-Marie Boutin, a priest-friend from Arborfield, and again in 2000 with Connie and their children. While spending five years in Europe, Thérèse Laforge visited the Lanthiez farm in 1973 . When Leona Beaujot, with her school friend Linda Bakos, visited in the families of Roger and Marguerite Domicent and Thérèse and André Lanthiez in 1973, she also met Father Pierre Devos and Emile Mullie, noticing his strong resemblance with his older brother (her grandfather Paul Mullie). In 1974, when Louise Mullie was a 19-year-old volunteer at L'Arche Bethléem in Brussels, she visited the Lanthiez family, including Emile Mullie, then travelled in France and Spain with her Canadian cousin Thérèse Laforge. Fred Mullie worked as a bellhop (chasseur-bagagiste) at Henri and Renée Mullie's Hôtel Victor Hugo in June and July 1982. Annette Mullie visited on her own in 1979 on her way back from Botswana, then from England with Andrew in 1982 (Henri Mullie's 50 th), 1984, 2013 (funeral of Henri Mullie) and 2016 ( $90^{\text {th }}$ birthday of Thérèse Lanthiez). When Honory Beaujot was in Argentina, he went to the wedding of Eric and Cristina Lanthiez in Rio (1981); after the wedding of Honory and Deanna in Buenos Aires (1982), Leon and Dorothy Beaujot, with their daughter Jeanette, visited with Eric and Christina at their farm in Brazil. On their way back from Turkey in 1986, Norbert and Dolores Beaujot and family were warmly received when they arrived unannounced at the Paris hotel of Henri and Renée Mullie. In May 2014, Annette and Andrew Gunn, Rod and Liz Beaujot and Art and Gerry Laforge represented the Canadian families at the occasion of Jean Mullie's $85^{\text {th }}$ birthday celebrations in Arras.

The generation of second cousins also made several trips in the other direction. In 1969, Chantal Domicent obtained a bursary from the Belgian office for external trade, allowing her to travel across the 
country visiting the Belgian embassies and consulates. As she was based in Montreal for six months, her parents Roger and Marguerite Domicent took the opportunity to visit across the country. Her sister Christiane also came to Montreal in 1969 and in about 1972/73, Yves Domicent accompanied his mother for a second visit in Canada. As indicated above, Pierre Mullie made an extensive visit with his uncle Robert in 1981. Eric Lanthiez and Jean Xavier Mullie, at age 19 in 1975, first worked in the Ontario tobacco harvest then made their way to Saskatchewan. In 1978, Christophe Mullie had a similar adventure, including tobacco harvest in Ontario and travels across to Vancouver. He remembers being with Leon and Dorothy Beaujot at harvest time. In 1978-79, Marguerite and Albert Denoël, with their three eldest sons, spent a year in Montreal while Albert did his residency in surgery at Hôpital Notre Dame. When they first arrived, they stayed with Joseph and Tillie Mullie where Jennifer Mullie rescued their three-year-old Alain who had fallen into her parent's pool. At the end of their stay, the Denoël family travelled to Vancouver, visiting families in Ontario and Saskatchewan. With their Holstein association, Dominique and Florence Mullie made a 1996 visit to dairy farms in Quebec. Sophie Mullie made a number of trips, including 1985, 1991, 1995 and 2007. In 2013, Sophie celebrated her $50^{\text {th }}$ with the theme "Colours of Canada," and since 2015 she has been seeking out winter activities in Canada every year. In February 2018 she visited with Fred and Kiersten Mullie in Vancouver, plus travel between Prince Rupert, Jasper and Banff, then Calgary with visits with Armand and Marlene Mullie and Honory and Deanna Beaujot. In February 2019, she was in Calgary (adding Annette and Andrew Gunn, Stephen and Susan Mullie), Saskatoon (Leon and Roxanne Laforge), Minnedosa (Tony and Peggy Mullie), London (Rod and Liz Beaujot). The train from Saskatoon to Rivers, Manitoba, was only 9 hours late! The COVID19 epidemic forced Sophie to cancel her plans for a visit in the winter of 2020-21.

In the next generation, Justine Mullie made a school exchange with Julia Laforge in 2002-03, when they were aged 13 and 16. Hubert Darras (2005) and Théophane Mullie (2017) arranged for placements on farms in Saskatchewan in the course of obtaining their degrees in Agronomy. While doing a European master's in marine biology, Francine Beaujot represented the Canadian families at the 2018 celebrations of Sophie Mullie's birthday at Le Touquet, and at the marriage of Rodrigo and Jennifer Lanthiez at Hondainville. In 2018-19 Emilie Mullie with her husband Marc Forster and their daughter Colombe spent a year in Montreal with Emilie's father's company Forme et Sport.

\section{Smets}

In their first trip to Europe (18 February - 30 March 1976), Leon and Dorothy Beaujot visited relatives on the Beaujot, Sénéchaud and Mullie sides of the family, but not on the Smets side. They did drive through Saint Trond (Sint Truiden in Flemish), Belgium, and Dorothy had felt an affinity as if part of her belonged there, but they had no addresses to look up. Dorothy's mother, née Julienne Smets, had died in 1959 and, since that time, there had not been exchanges with the Smets family. We found out later that Julienne's husband, Paul Mullie, had sent to the Smets family in Belgium the pictures taken at the time of their 1910 wedding. 
We also knew that before his death in 1967, Paul had become very preoccupied by something that he called a "hypothèque." As his dementia increased, he would frequently refer to a need to resolve this issue, having to do with a mortgage. When I asked my parents about this "hypothèque," they did not know much, but they thought it was some money from Europe that Paul thought was due to him, possibly an inheritance. I had also remembered an occasion in the late 1950s, at the Laforge farm in Zenon Park, when the fathers (Philippe Laforge, Mike Mullie and Leon Beaujot) were looking after the children playing in the yard. The men were joking that they were expecting some kind of inheritance from a rich European uncle or aunt who had no children.

It was around this time, in about 1961, after the 1959 death of her own grandmother, Josephine Dutois (née Smets), that Ria Weets, as a young teenager, sought to make contact with her family in Canada. She had learned in school about migration from Europe to Canada and USA. Her Uncle Paul had come back from the Congo and she asked him if he knew the address of her grandmother's sister in Canada. She also asked her Uncle Lucien who was head of the post office in Evere (Brussels) who also did not know the address. Ria decided to try nonetheless, and she wrote a letter to the "Mullie family, Saskatchewan, Canada." Needless to say, this letter was never received.

In 2007, as I was orienting myself to write this book, I told my parents that I was wanting to identify and make contact with all of their first cousins. They provided me with the contacts that they had made, but my father felt that I should not try to contact cousins on the Smets side because there were some hard feelings. I asked if this had something to do with the "hypothèque" question that had preoccupied my grandfather, and my father confirmed that this was his concern. Needless to say, I did not follow his advice.

\section{Reconnecting across the Atlantic: The Smets side}

We had previously known very little about the Smets family. My mother would recall two things from François Smets (whom she called her Uncle Frank). She remembered him carrying her on his shoulders, and his jumping out of the wagon to open the gate to the yard as the family came back from church. She knew that her Uncle Frank had come to Saint Hubert before her parents, he had later returned to Belgium to get married, and had not subsequently come back to Canada. She also knew that he married well and had no children, which raised suspicions in my mind about the "hypothèque" question.

We knew that the Smets were the most Flemish side of the family, having seen that our grandmother, who was very good at languages, would switch to Flemish as she counted into the higher numbers. We knew that she was from Sint Truiden and that this was the same place as Saint Trond, its French name. We also knew that there had been stepchildren in the family, but we did not know how this had come to be, and we certainly had not appreciated the associated family conflicts. We also knew that there had been a double marriage in the Smets family, but we did not know that it involved our grandmother and her sister Josephine who married Jules Dutois. We had heard that this marriage day, 19 July 1910, was a glorious day at their home Sint Truiden, surrounded by apple and cherry trees. 
The breakthrough in re-establishing contacts with the Smets family came when Betty Mullie uncovered the legal documents associated with the will of Thèrese Smets. Being the oldest of the children of Raymond and Maria Mullie, and having lived in the home inherited from her grandparents (Paul and Julienne Mullie), Betty had collected various documents left behind after the death of her own parents in 1999 and 2002. Julienne had written "Testament de Thérèse" at the top of this document. Realizing its importance, Cyril Laforge (2009) entered the first page in Google Translate so that we could decipher the Flemish. We were able to determine that this will, of Thérèse Smets, had been drawn up on 16 March 1944 and that she had died on 10 November 1946. The will specified that various items were to be distributed to specified members of the family, including Mrs. Mullie-Smets. We later determined that Thèrese Smets had never married and she was the oldest full-sister of Julienne Mullie (née Smets).

In about July 2009, I then tried to find some of the names using an international telephone directory for Sint Truiden. After trying unsuccessfully some of the "Smets" names cited in the will, I decided to try "Lucien Dutois" which was a less common name. To my surprise, there was an immediate answer saying: Oui, ici Lucien Dutois. A few moments later, I realized that he was a first cousin of my mother. He especially remembered that he had another first cousin, Jean Mullie, who had died of appendicitis at 16 years of age in 1929. We continued our conversation as I sought to establish the names in the rest of the family. This proved difficult as we were speaking in French which, for both of us, was a second language: his first language being Flemish and mine English. In order to reconstruct the genealogy, I would send him a written version of what I had understood over the phone and Lucien would make corrections.

Lucien Dutois also sought help from Lutgarde Vendrickx, a cousin who also lived in Alken (next to Sint Truiden). When I eventually spoke directly with Lutgarde, and when we met in 2012, I very much recognized my grandmother's voice, as an older woman (she was 90 in 2018) who spoke French with a Flemish accent. Thanks to the friendship that had developed between Lutgarde Vendrickx and Lucien Dutois, although they were from the two parts of the family that did not always get along, we were able to reconstruct much of the genealogy from both the first and third marriage of Josef Nicolas Smets. Lutgarde observes that the language of education was French when she was young in the 1930s. The first Flemish university was not established until 1945.

After several long conversations with Lucien Dutois, he suddenly asked if he could ask me a question. "Of course," I said, to which he replied, "do you know what question I am going to ask you?" "Damn it," I thought, he is bringing up the "hypothèque." I responded that I had heard my grandfather, in his last years, speak of a "hypothèque," but had never understood what this was all about, and it was not at all the reason for my reestablishing contact. We quickly agreed that this was a problem across sisters from the previous generation and had nothing to do with us.

Lucien Dutois also sent family pictures. One of these is particularly remarkable. It was taken by Lucien and shows his wife Simone as well as his brother André and Germaine Dutois and their young daughters Jenny and Maggie. These names are all labelled at the back of the picture, but there is another older couple in the picture who are labelled as "Les Canadiens." As soon as I saw this picture, I knew that "Les Canadiens" were Julien and Marie-Louise Mullie. This is proof that, when Julien and Marie-Louise visited 
their families in Belgium and France in March-June 1953, they also paid a visit to the family of Julien's sister-in-law, Julienne née Smets.

I never met Lucien Dutois, as he died on 3 March 2012 at the age of 92, just a few months before Liz and I, along with Annette and Andrew Gunn, visited in June 2012. By all accounts, he was a very proper and kind gentleman. He was the last to die among the Europeans in this generation of first cousins, survived by Dorothy Beaujot and Michel Mullie in Canada.

It was this same Lucien Dutois who had written a letter (dated 5 July 1960) to his uncle by marriage, Paul Mullie, thanking his uncle for having sent pictures taken from the 1910 wedding album of Julienne and Paul Mullie. While it was unfortunate for the Canadian family, it was certainly appreciated as a kind gesture on Paul's part, after the death of his spouse, to have sent these pictures from the wedding album back to the Smets family in Belgium. In his letter of thanks, Lucien Dutois mentions in particular pictures of his mother (Josephine Dutois). Not only were these Smets sisters married on the same day, but their deaths both occurred in 1959 (25 January for Josephine and 12 November for Julienne). In his letter of thanks, Lucien Dutois says that these pictures were providing occasions to visit with his sister Marie Louise (Malou) Weets, his brother Paul and Lucie Dutois, who were then stationed in the Congo, and Jaqueline (Jackie) Smets, the daughter of his uncle Antoine Smets.

The March 2012 death of Lucien Dutois had brought together others in the Smets family, whom we visited in 2012 and 2014. In particular, Paul Dutois (son of Lucien), cooked up a glorious meal at his home in Brussels, when this second cousins came for a visit on 18 June 2012. He also invited his first cousins (through his Aunt Malou and Jos Weets): Hugo Weets, Ria Weets, and Paul Weets. We subsequently met Luk Weets who showed us around Sint Truiden, and their sister Lieve Weets who hosted a gathering in Tervuren. Luk also took us to the historical town of Tongeren, to visit daughters of his Uncle André Dutois: Maggy Vranken and Jenny De Pauw. In the summer of 2019, Jenny De Pauw's daughter Fabienne and her family visited during a trip that took them from New York and Washington to Toronto and Montreal.

Through these visits and various exchanges by e-mail, Ria Weets feels that she did get a response to the letter that she had sent as a teenager to the "Mullie family, Saskatchewan, Canada." The contacts in the generation of second cousins started on 18 June 2012 with a rendez-vous at Le Roy D'Espangne (Grand Place 1 Brussels), a brasserie that served delightful Belgian beer. We continued with various tours, home cooked meals, invitations for coffee, restaurants and bars in Brussels, Sint Truiden, Alken, Leuven, Tongeren and Tervuren. In 2014, the visitors included Art and Gerry Laforge, along with Annette and Andrew Gunn and Roderic and Elisabeth Beaujot. We feel that we share an important bond because our grandmothers (Julienne Mullie and Josephine Dutois, both née Smets) were married on the same day in July 1910. In both visits, we also spent fruitful hours at the Sint Truiden archives, recording information on our Smets relatives from vital statistics (births, deaths, marriages) and population registers. 


\section{The family of origin of Julienne Smets}

Julienne Smets, mother of Dorothy Beaujot, was born on 2 April 1878 in Sint Truiden, Belgium, daughter of Jozef Nicolas Smets (1839-1908) and Maria Philomena Penxten (1839-1903). Julienne was the fourth of their six children, and she also had three older stepsiblings from her father's first marriage. Jozef Nicolas was a baker. The family lived at 25 Hamelstraat, Sint Truiden ( 25 rue des Moutons, Saint Trond) ${ }^{12}$. This is also the address shown on the death certificates of both Jozef Nicolas and Maria Philomena.

Jozef Nicolas Smets was born in Aalst, Belgium (now a suburb of Sint Truiden). His parents were Nicolas Smets (1793-1874) and Ida Tits (1798-1856), who were married in Aalst in 1835. Both of the parents of Jozef Nicolas Smets were born and died in Sint Truiden, where the father was a farmer. The parents of Maria Philomena Penxten were Engelbertus Penxten dit Peyschen (1792-1880) and Maria Ide Vanvinckenroy (1794-1853), who were married in Alken in 1831. Both of Maria's parents were born and died in Alken (12 km from Sint Truiden).

Art Laforge (2017a) has established further ancestors of Julienne over 14 generations starting with Jacques Jacquimar de Bay, born in 1385. In this genealogy, where Julienne and her siblings are shown as the $1^{\text {st }}$ generation, the Smets name first appears in the $6^{\text {th }}$ generation (Henri Smets, married in 1722) and the Penxten name first appears in the $8^{\text {th }}$ generation (Joannes Penxten married circa 1631).

In order to reconstruct the family, we need to go back to the first marriage of Jozef Nicolas Smets (18391908) to Jeanne Johanne Mommen (1826-1868) in 1861 in Sint Truiden. Jeanne Johanne was born and died in Sint Truiden. Her parents were Pierre-Jean Mommen and Marie Anne Ouwerx dit Ouwerk.

Jozef Nicolas and Jeanne had three children, born within the first six years of their marriage: Maria in 1862, Jozef in 1864 and Grégoire in 1866. Their baby was 2.5 years when their mother died. A year after the death of Jeanne, Jozef Nicolas married Cathérine Mommen (1831-1870), the sister of his first wife, in 1869. They did not have children, and Cathérine died a year after the marriage.

As indicated above, the third marriage of Jozef Nicolas was to Maria Philomena Penxten (1839-1903) in 1871. At this time, his three children were aged 5 to 9. Jozef Nicolas and Maria Philomena had six children, born within 11 years of their marriage: Thérèse in 1872, Antoine in 1874, Matilde in 1876, Julienne in 1878, Josephine in 1880 and François in 1882.

Maria Philomena was hard on her stepchildren. The oldest, Maria, who would become Sister Adeline, recalled to others that soon after her father's remarriage, when she was nine, the stepmother told her to "go to her home." As they became young adults, Jozef and Grégoire were not allowed to further their

\footnotetext{
12 Since Sint Truiden is in the Flemish part of Belgium, the street is now known as Hamelstraat. Hamel is an old Dutch word for castrated sheep. This was also the name used when French was the only official language. However, the vital statistics documents from that period translate the name as "rue des Moutons".
} 
education, and they became bakers like their father. While the family of Jozef Smets lived on the same street as the family of his father and stepmother, they did not have much to do with each other, after the death of Jozef Nicolas in 1908. For instance, when René (son of Jozef and Meike Smets, and grandson of Jozef Nicolas and Jeanne Smets) was being ordained priest, someone suggested that members of the other family should be invited. René's father was completely opposed, saying "if you go through that door, I will leave by the other." Another incident that is remembered involves Maria Philomena seeing an automobile for the first time and saying: "watch out child, a vehicle moving without horses pulling it is an invention of the devil for sure."

His father having been a farmer, and the father of his first wife was a baker, Jozef Nicolas Smets was baker, landowner, and he had a grocery store (boulangerie, porcherie, épicerie) in Sint Truiden. At his second marriage, both Jozef Nicolas and Cathérine are listed as bakers (boulanger). In the population register he is also entered as cattle merchant (marchand de bétail). He had considerable land, from his own inheritance as well as that of his wives, plus his own work and that of his family. His daughters would eventually take over the grocery store. Josephine continued to look after the store when Julienne left for Canada. His other daughters, Thérèse and Mathilde, had a store selling fabrics.

Sint Truiden is a fruit growing area in Belgium. It is particularly beautiful in April when the fruit trees are in blossom. This is now promoted to tourists for walking and cycling tours. The area is also known for a fruit tart called "Limburgse Vlaaien," that has cake at the bottom, covered with fruit, such as apples, plums, pears and cherries.

Jozef Nicolas Smets would have had orchards and he would have sold the fruit in the grocery store: cherries, apples, pears. Workers were hired at harvest time. Occasionally, the unemployed were forced to pick fruit. This was a difficult and unpopular job. To show their dissatisfaction, the workers would put their finger into the fruit, especially cherries, so that it could not be sold. Eventually, the extra workers were let go.

Soon after the birth of their last child, Jozef Nicolas Smets took in a domestic worker by the name of Bert (born 7 March 1872, died 13 December 1946) who came to live with them as of age 12. Bert was the oldest child in a large family whose mother had died. Josef Nicolas saw a young father crying while working in the fields. Asked why he was crying, the man said that his wife had just died, and he did not know how he would manage. Josef offered to take one of the children. Bert was like an adopted son who would spend 62 years with the Smets and Dutois families. He was particularly important to the grocery store, taking care of purchases and sales to other stores, collecting parcels from firms, farms and breweries, and delivering goods to clients. He also took care of the family's horses and carriage.

The 1901 Population Register allows us to depict the family at that time, when both Jozef Nicolas and Maria Philomena were aged 62. Maria, the oldest of the first marriage, had entered the Congregatie du Zusters van Liefde de Gent (Sisters of Charity) in 1882 as Zuster Adeline. Jozef and Grégoire, the sons of the first marriage, had both married in 1889 and now had 6 and 5 living children respectively. The family of Jozef Nicolas (listed as a baker) and Maria Philomena were living at 25 rue des Moutons, Sint Truiden, 
with their six children aged 19 to 29 (Registre de Population 1901, Saint Trond 6, Folio 1151). Living at the same residence, we find the sister of Maria Philomena, as well as a male baker's assistant (JeanHubert Claes, ouvrier boulanger, age 29) and a six-year old female servant (Alice Pypops).

Maria Philomena died in 1903 at the age of 64 and Joseph Nicolas died in 1908 at the age of 68 . At the time of his death in 1908, the three children of the first marriage of Joseph Nicolas were independent: Maria had become Zuster Adeline in 1882; Jozef and Grégoire had married in 1889 and all their children had been born. In the second family, François had left for Canada in 1907, and the others were helping with the family business: Thérèse and Mathilde would remain single, and Julienne and Josephine would marry in 1910 and Antoine in 1914.

\section{The children of (1) Joseph Nicolas and Johanne Smets and (2) Joseph Nicolas and Maria Philomena Smets}

Josef Nicolas Smets had three children with Johanne (née Mommen) and six children with Maria Philomena (née Penxten). The children were all born in Sint Truiden. All nine children survived to adult ages, six were married and five had children. In 1889, the brothers Jozef and Grégoire Smets married two sisters: Anna Maria and Christina Fabry. In 1910, the sisters Julienne and Josephine Smets married on the same day.

Maria Smets (1862-1925) was the first born. At Gent, on 8 May 1882, Maria became Zuster (Sister) Adeline van de congregatie van de Zusters van Liefde in Gent (Sisters of Charity). She was also known in the family as Tante Nonneke (Aunt Nun). Zuster Adeline worked at a hospital for the mentally ill in Sint Truiden. She died in Sint Truiden on 1 December 1925, at the age of 63.

Jozef Smets (1864-1939) married Anna Maria Rosina (Maaike) née Fabry (1862-1939) on 13 November 1889 in Sint Truiden. Jozef was a baker like his father. The 1901 Population Register lists the family at the address of 35 Place des Moutons (35 Hamelstraat) with their five living children aged 1 to 10 (Registre de Population 1901, Saint Trond 6, Folio 1164). Also listed are a servant and a baker's assistant. The 1911 Population Register lists the same family at this address with their 6 living children aged 5 to 18, plus Joseph's brother Grégoire. Jozef and Anna Maria had nine children, six of whom survived to adult ages: Alphonse (1891-1893), Maria (1893-1936), René (1894-1953), Martha (1896-1963), Gustave (1898-1899), Julia (1900-1906), Emma (1900-1988), Gabriel (1903-1980), and Marcel (1905-1988). Jozef and Maaike both died in Sint Truiden in 1939, at the ages of 75 and 77.

Lutgarde Vendrickx, daughter of Emma, remembers going from Alken by train to visit her grandfather at 35 Hamelstraat (35 rue des Moutons), Sint Truiden. During the war of 1939-45, it took an hour and a half to make the trip by bicycle, but the grandfather was always waiting their arrival on the sidewalk. Since his sons were established, the daughters Martha, Emma and Gaby inherited the house and store in Sint Truiden after their father died in 1939. There was a large door on the street, through which a horse could pass, to the back where there was a stable, garden and grape vines. On the ground floor was a dry goods store (flour, sugar, coffee, rice, etc.) with a large stairway going to the next level. Behind the store 
was a kitchen and living room. The second floor had four bedrooms, and the third was used as a large multi-purpose attic. This property was sold in during the war for 600 French Francs, and the property was subsequently converted into a large house.

- Maria Smets entered the same order of sisters as her Aunt Maria. She became Zuster Maria in 1918 in the Congregatie van de Zusters van Liefde in Gent (Sisters of Charity of Gent). She was an educator and taught school at various places. Zuster Maria died at the hospital in Antwerpen at the age of 43, on 9 September 1936.

- René Smets was ordained priest in 1920. He served as vicar in Liège, then as chaplain in Diepenbeek. Father René died in Diepenbeek at the age of 59, on 21 November 1953.

- Martha married Mathieu Schreurs on 29 March 1932 (same date as Gaby) in Sint Truiden and had two children: René (1933-2013), and Marie-Louise (b. 1938, lives in Sint Truiden). Mathieu was a bank manager in Diepenbeek. Martha died in Diepenbeek at the age of 67, on 22 May 1963.

- Emma married Camile Vendrickx in August 1925 in Sint Truiden. Emma and Camile lived in Alken where Camile was a schoolteacher (Grade 2). They had two children: Luc (1926-1992, ordained priest on 22 July 1951) and Lutgarde (1928-2019).

- Gabriel (Gaby) married Paul Lavigne on 29 March 1932 (same date as Martha) in Sint Truiden where Paul was a schoolteacher (Grade 6). They did not have children. Gabriel died at the age of 87 in Sint Truiden, on 5 September 1980.

- Marcel Smets married Paula née Maleux on 22 May 1933 in Borlo (10 km south of Sint Truiden). Marcel and Paula lived on Leopoldstraat in Sint Truiden, where Marcel was a doctor. They had nine children: Yolande, Christiane (1935-1935), Luk, Guy, Jaak, Klara, Ria (1942-1986), Simone, Lutgarde. Marcel died at the age of 83, on 22 December 1988, and Paula at the age of 97 on 15 November 2009.

Grégoire Smets (1866-1935) married Christina (Stina) née Fabry (1862-1939) on 12 December 1889 (a month after his brother) in Sint Truiden. Grégoire was a baker like his father and brother, in Zepperen ( 5 $\mathrm{km}$ from Sint Truiden). In 1896 he opened a bakery, pastry and spice confectionery in the historic home called Hoebanx-Boonenop. Grégoire and Christina had seven children, six of whom survived to adult ages: Jozef (1890-1966), Jeanne Maria (b 1893), Jean Jozef René (1895-1966), Anna (b 1898), Marie Louise Henriette Séraphine (b 1890), Marie Léonie Marthide (1902-1907) and Virginie-Antonie (b 1906). The first three children were born in Diepenbeek, the $5^{\text {th }}$ in Sint Truiden, and the last two in Zepperen. Grégoire died in Sint Truiden in 1935, at the age of 69, and Stina in 1940 at the age of 75.

- Jozef Smets married Anna Jérome circa 1923 and had two children: Christiane and Anna. Jozef was a professor at Versailles, France. He died at the age of 75, on 25 May 1966.

- Jeanne Anne Maria was never married. She lived with her parents until their death then was housekeeper for priests at Zepperen. Maria died in Zepperen.

- Jean Jozef René Smets married Simone Rousselet circa 1927. René worked in the offices of a coal mine at Diringen. René and Simone had two children: Jean and Nicole. René died at the age of 71, on 12 May 1966. 
- Anna married Joseph Mangon circa 1932 and had one child: Suzanne. Suzanne's son is a doctor in Zepperen.

- Marie Louise Henriette Séraphine married Lambert Dantoin circa 1925.

- Virginie-Antonie was never married.

Thérèse Smets was the first born of the second family, on 5 September 1872, when her stepsister and brothers were 10, 8 and 6 years of age. The 1901 Population Register places her with her parents and the five other children of Jozef Nicolas and Maria Philomena Smets, at 25 Hamelstraat, Sint Truiden (25 rue des Moutons, Saint Trond). In the 1911 Population Register, when both of her parents were deceased, she is listed with her sister Mathilde Smets (born on 19 August 1876) at 34 Hamelstraat, across the street from 35 Hamelstraat where her stepbrother Joseph and his family lived. Thérèse and Mathilde operated a store selling fabrics. Mathilde died on 25 March 1943, at the age of 66, in Sint Truiden. Thérèse died on 10 November 1946, at the age of 74, also in Sint Truiden.

It was the will of Therèse Smets that enabled us to find the Smets family in Belgium. In spite of the conflicts across families, Thérèse instructed in her will for distribution to her sisters and brothers (or their descendants) of both families. At the time of the deaths of Mathilde and Thérèse, their three stepsiblings had also died (Maria in 1925, Grégoire in 1935 and Jozef in 1939) as had her brother Antoine (in 1929).

Antoine Smets married Jeanne Joséphine Céline née Cox on 16 July 1914 at Sint Joost Ten Node. They had three children, all born in Sint Truiden, with two surviving to adult ages: Jean (b 1915), Jackie (19181918) and Jacqueline "Jackie" (1922-circa 2000). Antoine was manager (régisseur), looking after the treasury of the worker's housing committee in Sint Truiden. He also operated an auto-car or taxi service. The 1913 Population Register for Sint Truiden (Folio 4139, p. 1420) lists Antoine and Jeanne with their son Jean, at 46 Schepen Dejonghstraat, Sint Truiden (200 meters from Hamelstraat 35 where the family of his stepbrother Jozef Smets lived. This register also indicates the birth and death of Jacqueline in 1918 and that the family subsequently moved to Saint Juste Ten Noode (Sint Joost-Ten-Node, near Brussels). Antoine died at the young age of 55, on 24 November 1929 in Sint Truiden, when his children were 14 and 6 years of age, with his wife Jeanne dying 3 years later. After their mother's death, Jean and Jacqueline (Jackie) went to the Sint Joost-Ten-Node commune near Brussels.

- Jean Frans Jules Smets married and had one child born about 1940.

- Jacqueline (Jackie) Smets married Robert Delespesse. They lived in Brussels where Robert worked in an office. Jackie died circa 2000. They had no children.

Julienne Smets and Josephine Smets were the next born, in 1878 and 1880 . As with their sisters Thèrese and Mathilde, they would have attended a boarding school for young girls (Pensionnat pour Jeunnes Filles) with Catholic Sisters in Sint Truiden. They studied home economics and languages (French, English and German). Josephine furthered her knowledge of English through an exchange in England. Julienne maintained reading fluency in these three languages for her whole life, but mostly spoke French, and always counted in Flemish, her mother tongue. Julienne and Josephine were married on the same day, 19 July 1910, in Sint Truiden. The wedding pictures were taken in the garden of the parental home: 25 
Hamelstraat, Sint Truiden. From the pictures we see a leather chair with brass nails. These chairs remain in the family and are at the apartment of Hugo Weets, Josephine's grandson. They each had four children who survived to adult ages, including daughters Marie-Louise Dutois born in 1916 and Dorothy Mullie born in 1917, both married in 1945. Their engagement rings were later passed on to Dorothy Beaujot and Malou Weets. Julienne's ring is inscribed with "Paul à Julienne 24 avril 1910;" it was worn by Dorothy Beaujot and is now with her daughter Doreen Gardner. Josephine's ring is inscribed with "Jules à Josephine avril 1910;" it was passed on to Malou Weets and it is now with her daughter Ria Weets. This April engagement date is remembered as a time when the orchards of Sint Truiden were in full blossom, especially the cherry trees. Julienne and Josephine both died of diabetes, in 1959.

Julienne and Paul Mullie lived for a year in Wingene, where Paul was managing the agricultural operations of the Ruiselede reform school (now called De Zande ${ }^{13}$ ), after obtaining his Agricultural Engineering Degree at University of Leuven in 1905. At the time of his marriage, Paul Mullie was living in Wingene. Then, in March 1911, Julienne and Paul travelled to St. Hubert, Saskatchewan where they were farmers. Julienne and Paul had five children: Marie-Louise (1911-1992), Jean (1913-1929), Raymond (1915-1999), Dorothée (1917-2014), Michel (1920-2014). Their four children who survived to adult ages were married between 28 December 1944 and 19 June 1946 and had a total of 28 children (see Appendix 3.4). Julienne died in Whitewood at the age of 81, on 12 November 1959, and she is buried at Saint Hubert. The further description of their lives is left to Chapter 5.

Josephine and Jules Dutois lived in Sint Truiden where they continued to operate the grocery store at 25 Hamelstraat. Jules Dutois was born on 27 April 1876 in Uikhoven, 45 km north-east of Sint Truiden, on the Meuse River (Maas in Dutch/Flemish). In the marriage registration, on 19 July 1910, Jules is listed as a farmer ("cultivateur") living in Sint Truiden. Besides operating the grocery store, they had fruit trees and a bakery. They also benefited from the work of Bert, who had come to the Smets family in about 1884 at the age of 12 , after his mother's death, and continued to work for the Dutois family until his own death in 1946.

After their marriage, Josephine and Jules went to Paris for their honeymoon, travelling first class on the train. The brim of Josephine's hat was so wide that it did not fit through the door. She had to remove it to get into the train. She always wore a hat and in cold weather, also a muff. Her muff contained a zippered compartment in which she kept her handkerchief, pills, rosary, money, lipstick, rouge, gloves, glasses, etc. Her umbrella was made with whale bones and her cane had an ivory handle. She also had a mink scarf that smelt badly ("stonk uren in de wind"), which she denied. She spoke Flemish with the accent of Limburg, but she considered Flemish to be a language fit only for the working class. Her language of study and preference was French. She also learned English.

Josephine and Jules had four children: Paul (1912-1997), André (1914-1989), Marie-Louise (1916-1989) and Lucien (1919-2012). Jules died at the age of 60 on 27 April 1936 when the children were aged 17 to 24. Josephine continued to operate the grocery store until she retired and moved to Brussels to be

\footnotetext{
${ }^{13}$ See Chapter 5.
} 
closer to her children Marie-Louise (Malou) and Lucien. Josephine subsequently lived with her daughter Malou and family in Tervuren, then Poppel. When Ria Weets, her granddaughter, contracted pneumonia, the grandmother paid for the medicine which was very expensive at the time (equivalent of two months wages per treatment). Her parents had just bought a beautiful house in Tervuren and penicillin was not covered under the social care system. The doctor had to come three times per day. At the end of her life, when Josephine was suffering from a coma brought on by diabetes, she lived in a "hôme" in Londerzeel. She died on 25 January 1959, at the age of 78.

When Josephine lived in Poppel with her daughter Malou and family, she occupied a place of privilege in the church. The first row was reserved for village officials and members of the clergy. In the second row to the right she had paid for her own personal chair made out of ebony, with red velvet cushions and her name spelled with copper nails. This class distinction was eventually abolished, and all chairs were replaced by a common model so that she had to pay "chair money" each Sunday, like everyone else. Josephine was very annoyed at this church reform.

In 1939, the children of Josephine and Jules Dutois were aged 20 to 27 . With the German invasion on 10 May 1940, a serious attach occurred at the military airport of Brustem, $6 \mathrm{~km}$ from Sint Truiden. Josephine awoke to the terrible noise of the German bombardment of the airport. All the planes standing there were destroyed. That morning the radio said: "we are at war with Germany." Paul was called to military duty in the defense of Belgium. After 18 days of fighting, the Belgian army surrendered, and Paul was taken captive. He was subsequently de-mobilized and allowed to return to Sint Truiden. Malou got her certification as a Red Cross nurse in Sint Truiden. Had she not been working for the Red Cross, she would have been taken to work in Germany. There was much damage in Sint Truiden during World War II. In the Battle of the Scheldt (2 Oct to 8 Nov 1944), Canadian forces played an important role in opening the shipping route through Antwerp so as to supply Allied forces in northwest Europe.

Meanwhile, the family's grocery store, at 25 Hamelstraat, was a big success. The groceries included fruit from the orchards that belonged to the family. However, none of the children in the next generation were willing to take over the operation. Before the war, and shortly after the war, Josephine's son Paul and his spouse Lucie also worked in the store. By 1945, Josephine was 65 and her children were no longer living with her at 25 Hamelstraat. She closed the store and lived on her savings and the revenue of her orchards. At that time, self-employed people could not apply for a government pension as they had not contributed into the plan. The store was sold in about 1948. It is now a drug store. Josephine shared her savings with her four children: Paul and Lucie Dutois were living in the Belgian Congo; André and Germaine Dutois bought a house in Tongeren; Marie-Louise (Malou) and Jozef (Jos) Weets bought a house in Tervuren; and Lucien's part included taking care of his mother.

The four children of Josephine and Jules Dutois married and had a total of 9 children:

- Paul Dutois married Lucie née Deckers in 1937 in Limburg. Paul studied at an agricultural school and worked at the family grocery store. In 1939 Paul and Lucie travelled by The Congo Boat from 
Antwerpen to Matadi on the Congo River. They lived in Katanga where Paul was an Agricultural Engineer working for the Belgian Government. In their subsequent trips to Belgium, they travelled by plane through the airport at Evere. In 1960, when the Belgian Congo became the Republic of Congo, Paul worked in Senegal. At retirement, they moved to the community of Rotselaar, near Aarschot, Belgium. Both Paul and Lucie died in 1997, at the age of 85 . They did not have children.

- André Joseph Michel Dutois married Barbe Odile Octavie Germaine née Pexsters on 12 August 1942 in Sint Truiden. André took his schooling in French with the religious brothers at Sint Truiden. Germaine was at boarding school with the Filles de la croix at Waremme. André and Germaine had two children, both born in Sint Truiden: Jenny in 1945 and Maggy in 1950. In 1952 the family moved from Sint Truiden to Tongeren where André was a land surveyor, also doing independent surveys for the Court. At the end of his career, he was named Chief Controller for the Land Survey Division of Limbourg (Controleur en chef du Cadastre de Limbourg). André died on 2 May 1989, at the age of 74 and Germaine on 16 December 2006 at the age of 89.

- Marie-Louise "Malou" married Edmond Jozef (Jos) Weets on 3 April 1945 in Sint Truiden. Malou was 20 and living at a boarding school (pensionnat pour jeunes filles) in Liege when her father died in 1936. She had to be in mourning six months to a year, not allowed to play the piano or sing, posing problems for her passionate hobby. Later she lived with her brother Lucien who was working for the post office and had rented an apartment in Evere, Helmetsesteenweg (since 1952 Evere is one of the 19 communes of Brussels). Jos Weets originally had a chance to go to the former Belgian Congo, but he declined saying he wanted to have children. During the war, Jos worked at the frontier custom house near Adinkerke, on the border between Belgium and France. In 1948, he joined the Ministry of Finance (Customs and Excise) as Secretary of Administration. In 1951, he was promoted and sent to Poppel, where he was responsible for customs and excise at the border between Belgium and The Netherlands, including the enclave of Baarle-Hertog within The Netherlands (at Baarle-Nassau). With the European Common Market, starting in 1958, there was less checking of people crossing the borders. In 1963 Jos left Poppel to join the Brussels office of the Ministry of Finance. He finished his career as Director of Customs and Excise at the Ministry of Finance in Brussels, retiring at the end of 1979. Malou and Jos had six children born between 1946 and 1955, of whom five survived to adult ages: Hugo, Ria (Maria), Luk, Paul (1950-1950), Lieve (Godelieve), and Paul. In 1948, Jos and Malou purchased a large home called Villa Les Hirondelles, in Tervuren (Grensstraat 63 or rue de la Limite 63). This area of Tervuren subsequently became part of the community of WezembeekOppem. There is footage of the villa (hôtel de maître), built around 1910, in "Villa Les Hirondelles, Tervuren." While Jos was responsible for the Custom station of Poppel, the family lived in Poppel (now part of Ravels) for 1950-1960, then in 1960-63 they were in Turnhout where the children did their schooling at the Jezuiten college and the Heilif Graf Institute. In 1963, the family moved back to their home in Wezembeek-Oppem. In 1975 Jos suffered a stroke and he was at home for about a year before returning to work. He died in 1984 at the age of 67. Malou sold the house and lived with Hugo, her oldest son, until her death in 1989 at the age of 72. 
- Lucien Dutois married Simone née Jamaer on 15 August 1948. Starting in 1938, Lucien worked for the Post Office in Evere, Brussels. In 1938 he first rented a house on Helmetsesteenweg in Evere (now part of Brussels). After their marriage, they moved to the Consciencelaan in Evere. In 1957, Lucien became "responsible" of the Post Office Department, living on the first floor of the Post Office Building at Haachtesesteenweg 1031 in Evere. The family continued to live in Evere (Brussels) until Lucien's retirement in July 1984 when they bought a house in Alken (Motstraat 85). Lucien and Simone had one child: Paul. Simone died at age 85 on 6 February 2007 and Lucien at age 93 on 3 March 2012. In 2009, Lucien had moved into a retirement home with his little dog Toto.

François Louis Alphonse Smets, born on 26 September 1882, was the youngest in the family. He studied Agriculture at Leuven University at the same time as Paul Mullie, who would become his brother-in-law. The address on his student card is rue des Moutons 25. This document indicates the following: 1901 admission exam, 1904 Agricultural Engineering (Ingénieur Agricole) degree, 1905 Engineer in Agronomic Sciences (Ingénieur en Sciences Agronomiques). In the section regarding profession and residence after university, the document indicates: Ingénieur Agricole and Propriétaire à Saskatchewan (Canada). Leuven University was founded by Pope Martinus in December 1425, with Latin as its language. In the $16^{\text {th }}$ Century, Erasmus studied there, in Latin. At the beginning of the $20^{\text {th }}$ Century, the official language became French. Since 1911, Flemish students could study in Dutch and in 1936 the university became bilingual. In the 1960s, the French part was moved to Louvain-la-Neuve.

François came first to Souris, Manitoba in 1907, then to Saint Hubert, Saskatchewan arriving on 5 April 1908. He farmed S.E. and N.E. of 34-14-3-2 then N.E. of 12-15-3-2, spending the winter of 1920-21 in Belgium. This farm is 8 miles from that of Paul and Julienne Mullie. François (Frank) is shown in a 1917 picture that appears in Memories of Saint Hubert 1980 (p. 44). François made a final return from Canada to Belgium, arriving on 15 June 1923 (see 1920 Population Register for Sint Truiden, p. 1420). On 14 October 1926, François married Marie-Henriette Hélène Thissen (1882-1955). They lived in Aldenneik (Maasteik) where François was an agricultural engineer. They did not have children. François died on 6 March 1953 at the age of 70 and Hélène in February 1955 at the age of 72, in Aldenneik, Maaseik.

\section{A short summary: family, farming, war}

When I gave myself the objective of finding all the first cousins of my parents, I did not realize where this would lead. The four families of origin included a total of 36 people, that is, the parents, uncles and aunts of Leon and Dorothy Beaujot (see Box 3.2). In the next generation, that is the generation of the first cousins, there are 92 people ( 39 for Leon and 53 for Dorothy). These 92 had a total of 238 children ${ }^{14}$.

\footnotetext{
${ }^{14}$ See the notes to Box 3.2 for those missing from the counts.
} 


\begin{tabular}{lccl}
\hline \multicolumn{3}{l}{ Box 3.2 Four families of origin: Three generations } \\
& Parents/uncles/aunts & Generation of $1^{\text {st }}$ cousins & Generation of $2^{\text {nd }}$ cousins \\
Beaujot & 7 & 20 & 70 \\
Sénéchaud & 6 & 22 & 76 \\
Mullie & 8 & 30 & 90 \\
Smets & 9 & 28 & 56 \\
Total & 36 & 92 & 238
\end{tabular}

Source: Appendixes 3.1 to 3.4 .

Notes:

1. Leon and Dorothy Beaujot are the reference point of this table. They are counted in the generation of first cousins.

2. On the Sénéchaud side, the descendants of Léon and Marceline Sénéchaud and of Marcel and Alice Sénéchaud (generation of $1^{\text {st }}$ cousins) have not been located.

3. On the Smets side, both of the families of Jozef Nicolas Smets are included.

4. On the Smets side, the children of Séraphine and Lambert Dantoin are missing in the generation of $2^{\text {nd }}$ cousins.

5. The total counts people only once in the generations of first and second cousins.

In the generation of the parents/uncles/aunts of Leon and Dorothy Beaujot, 34 of the 36 lived to adult ages and 10 were farmers. On the Beaujot side, the four who settled in Canada were farmers. On the Mullie side there were five farmers, two in Canada and three in France/Belgium. In addition, Ernest Sénéchaud was a farmer near Parthenay, France. In the generation of first cousins, 79 of the 92 survived to adult ages and there were 30 who were farmers ${ }^{15}$ (16 in Europe and 14 in Canada), with 9 farms passing on to at least one further generation ( 4 in Europe and 5 in Canada). While it is difficult to make exact comparisons, it is clear that farming involved much hard work, especially in the first and second generations, and that the farms surviving into the third generation modernized in similar ways in Europe and Canada. The farms were larger in Canada, and mostly enlarged over generations on both continents.

While there are more similarities than differences on the farming side, the families in Europe were more affected by World Wars I and II. The Canadian families had migrated in the period 1892 to 1913, that is before the war of 1914-18. In effect, the anticipation of war played a significant part of the emigration decision of Julien Mullie in 1913. His brother Emile was conscripted in 1915 and spent several months in trench warfare. The rest of the Mullie family who were still in Belgium were refugees at Cany Barville, France. Marie-Louise née Duthoit, who would become the wife of Julien Mullie, lost her first husband due to mustard gas exposure. After the war of 1914-18, both Emile and his older brother Raymond were

\footnotetext{
${ }^{15}$ Besides farmers and agricultural workers, this includes persons who spent a significant amount of their lives in agricultural work.
} 
involved in reconstructing their farms from the destructions of the war. Raymond's daughter Jeanne lost an arm as she picked up what turned out to be a bomb.

In the war of 1939-45, the only Canadians directly affected were Leon Beaujot and Michel Mullie, in the $1^{\text {st }}$ cousin generation, both conscripted but did not serve overseas.

On the Sénéchaud side, Ernest Sénéchaud was unable to replace his work horse on the farm because the horses were part of the war effort, and he was kicked by the horse that he was trying to train for field work. This accident proved fatal, bringing Ernest's premature death in 1944 partly because of the limited healthcare available during the war. Among his children, the first spouse of Gisèle Sénéchaud went to war and was never seen again. Their son, Gilbert Sénéchaud, suffered from lung congestion in 1956, as he fought in the Algerian war. In the family of Radégonde and Honoré Largeau, Clovis Gagnères, married to Marguerite Largeau, was in the French military and became a prisoner of war in Austria during the war of 1939-44, then he was part of the post-war occupying forces in Germany. The first wife of Raymond Largeau, Germaine née Bernier and their 9-year old son were killed during the 1944 bombing of Angers. Raymond had been called up in the French army in September 1939, captured in Amiens, then imprisoned in a German camp near the Polish border where prisoners were sent to work in factories and farms, and liberated by Russian army in June 1945.

On the Mullie side, the family of Maurice Mullie, now at Étretat, France, also suffered in World War II. Their son Bernard was taken at gunpoint by German soldiers who wanted assistance in returning to their base behind the German line. Their daughter Marie-Louise risked her life to bring food to downed British parachutists, and her future husband Pierre Roland escaped from the conscription to Compulsory Work Service in Germany, eventually taking part in the 1944 liberation of Southern France. The farm of Emile Mullie, at Foncquevillers, France, was in the battleground across enemy lines, with shells still being recovered from the fields to this day.

On the Smets side, the family of Josephine and Jules Dutois were awakened on 10 May 1940 to the sounds of bombing at the Brustem military airport, and the radio announcement that "we are at war with Germany". Their oldest son, Paul, was called for military duty and later taken prisoner for a short while.

While the motivations for emigration to Canada were complex, including seeking out new opportunities on a faraway developing frontier, it is clear that the war of 1914-18 prevented returns to Belgium and France during that time. The return of Marie Beaujot in 1896, to marry Marcellin Godart, occurred before the war. Between the wars, François Smets returned to Belgium in 1923, to marry Hélène Thyssen, and remained in Belgium. Except for the trip of Julien Mullie in 1924 to marry Marie-Louise Duthoit, there would not be other Atlantic crossings until the early 1950 s. 


\section{Appendix 3.1 \\ Beaujot family genealogy}

François Joseph Beaujot (19 Nov 1822, Dinant, BE - 7 Nov 1892, St. Hubert, SK) married Justine Pauline Joseph née Derenne (17 Apr1835 - 8 May 1904, St. Hubert, SK) on 15 Feb 1860 at Dinant, BE, and had seven children: Léopoldine, Marie Joséphine, Eugène, Céline, Joséphine, Marie, Félicien.

1. Léopoldine Beaujot (22 Nov 1860, Gedinne, BE - 12 Nov 1931, Malvoisin, BE) married Léon Poncelet (24 Feb 1845, Malvoisin, BE - 19 Jan 1922, Malvoisin, BE) on 25 Jun 1880 at Malvoisin, $\mathrm{BE}$, and had five children:

Jules Poncelet (31 Dec 1881 - 1 Dec 1958) married Emilie née Flament (18 Sep 1878 - 19 Mar 1955) on 21 Feb 1903 at Malvoisin, BE, and had four children: Vital (1904 - 1979), Jean (1906 *), Georges (1910 - 1979), Reine-Marie Rosa (1917 - *)

Céline Poncelet (1 May 1884 - 27 May 1967) married Honoré Gillard (18 Oct 1874 - 11 Jun 1952) on 27 May 1905 at Malvoisin, BE, and had one child: Désiré (1922 - 1982)

Agnès Poncelet (3 Jan 1887 - 6 Dec 1975) married Arthur Parent (31 May 1887 - 9 Apr 1977) on 5 Aug 1915 at Malvoisin, BE, and had four children: Marthe (1916 - 1999), Léon (died very young), Léon (1920 - 1998), Jules (1924 - 1990)

Orpha Poncelet (19 Sep 1889 - 2 Sep 1943) married André Porrigniaux (5 Sep 1893 - 27 Jan 1979) on 6 Dec 1919 at Malvoisin, BE, and had two children: Olivier (1922 - 1977), Nelly (1926 *)

Laure Poncelet (23 Mar 1895 - 29 May 1965) married Auguste Berger (6 Dec 1891 - 17 Mar 1965) on 12 May 1923 at Malvoisin, BE, and had five children: André (1924 - 1974), Maria $\left(1926\right.$ - 1981), Jean $\left(1927-{ }^{*}\right)$, Maurice $\left(1931\right.$ - 1999), Simone $\left(1936-{ }^{*}\right)$

2. Marie Joséphine Beaujot (6 Mar 1863, Gedinne, BE - 9 Sep 1869, Gedinne, BE)

3. Eugène Beaujot (23 Jan 1866, Gedinne, BE - 8 Feb 1950, St. Hubert, SK) married Modeste née Ecolan (15 Sep 1885, Médréac, FR - 7 Aug 1967, St. Hubert, SK) on 27 Apr 1909 at St. Hubert, SK, and had three children:

Marcel Beaujot (6 Feb $1910-22$ Oct 1980) 
Mathilde Beaujot (21 Jan 1913 - 30 Dec 1986) married Emile Payot (9 Oct 1902 - 9 Jun 1995) on 7 Feb 1934 at St. Hubert, SK, and had four children: Albert (1936 - 2012), Denis (1938), Francis/Frank (1940 - 2008), Paul (1947)

Emile Beaujot (8 Jun 1915 - 4 Dec 1990)

4. Céline Beaujot (7 Feb 1868, Gedinne, BE - 14 Feb 1923, Morinville, AB) married Joseph Pirlot (1862, Patignies, $B E-1941$, Morinville, AB) in 1892 in Brussels, BE, and had four children:

Frank Pirlot (1892 - 19 Sept 1953 or 1954) married Jean née Cormack (6 Sept 1919 - *) on 17 Apr * at Morinville, AB, and had four children: Robert (1937), Louis (1941), Garry (1945), Elizabeth (1946)

Irene Pirlot (23 Dec 1894 - 25 Sep 1989) married John Hancock (12 Apr 1882 - 12 May 1951) on 19 Apr 1920 at Winnipeg, MB. and had four children: Anne (1921 - 2009), Charles (1922 2010), Francis (1924 - 2002), Margaret (1926)

Jack Pirlot (28 Mar 1898 - Jul 1986) married Catherine née Jacobi (16 Sep 1903 - Dec 1996) on 31 Mar 1924 at Manor, SK, and had three children: Thelma (1926 - 2010), John (1934), Joseph (1936)

Pirlot, female child, $1904-1904$

5. Joséphine Beaujot (8 Feb 1870, Patignies, BE - 6 Nov 1938, St. Hubert, SK) married Adolphe Gatin (28 Aug 1861, Patignies, BE - 26 Apr 1940, St. Hubert, SK) on 12 Feb 1892 at Patignies, BE, and had two children:

Ernest Gatin (3 Jul 1898 - 28 Jul 1984) married Anita née Tetu (28 Mar 1902 - 6 Apr 1987) on 30 Dec 1924 at St. Hubert, SK, and had six children: Armand (1925 - 1976), Isabelle (1928 - 1932), Marguerite (1933), Isabelle (1933 - 2000), Lionel (1937 - 2002), Laura (1941)

Emile Gatin (18 Aug 1901 - 20 Jan 1985) married Bernadette née Boutin (16 Dec 1903 - 25 Jul 2002) on 5 Nov 1924 at St. Hubert, SK, and had ten children: Anne Marie (1926 - 2017), Emilie (1928 - 2006), Gabrielle (1929 - 2002), Yvon (1931 - 2003), Victor (1933 -- 2020), Albert (1934 - 2004), Louise (1937 - 1989), Josephine (1939), Adolphe (1941 - 1978), Roland (1943 - 1995) 
6. Marie Beaujot (23 Dec 1874, Malvoisin, BE - 12 Mar 1934, Patignies, BE) married Marcellin Godart (28 Jul 1869, Patignies, BE - 3 May 1942, Bourseigne-Vieille, BE) on 14 Mar 1897 at Patignies, $\mathrm{BE}$, and had three children:

Adolphe Godart (30 May 1897 - 28 July 1967) married Marthe née Leonard (15 Apr 1900 - 19 Mar 1972) on 23 Oct 1924 at Patignies, BE, and had three children: Marguerite (1925 - 1982), Simone $\left(1929-{ }^{*}\right)$, Colette $(1936)$

Cécile Godart (18 Jul 1903 - 1974) married Nestor Gerard (22 Apr 1897 - 26 Apr 1969) at Patignies, BE, and had two children: Marcel (1937), Yvon (1940)

Maurice Godart (25 Jul 1906 - 6 Jan 1979) married Augusta née Marchal (21 May 1912 - 13 Dec 1993) on 26 Dec 1932, Bourseigne-Vieille, BE, and had one child: Louis (1945)

7. Félicien Beaujot, ( 8 Jun 1878, Malvoisin, BE - 8 Jan 1946, St. Hubert, SK) married Bertheline née Sénéchaud (4 Oct 1885, La Peyratte, FR - 19 Dec 1955, St. Hubert, SK) on 14 Jun 1910 at St. Hubert, SK, and had three children :

Flora Beaujot, (25 Apr 1911 - 28 May 1994), married Joseph Driscoll (5 Sep 1904 - 1 Jan 1972) on 20 Oct 1931 at Forget, SK, and had six children: Bertha (1933-2008), Joseph (1934), Monica (1935 - 1986), Jack (1938), Leon (1940), Bernice (1950)

Albert Beaujot, (1 Apr 1912 - 3 Oct 1988), married Grace Pelletier née Beaulac (9 May 1925 28 May 1986) on 15 May 1975 at Calgary, AB, and had two children: Alan Pelletier (1959), Leonard Pelletier (1963), and two stepchildren for Albert: Vivian Pelletier (1946) and André Pelletier (1948 - 2005)

Léon Beaujot, (29 Sep 1919 - 28 May 2014), married Dorothy née Mullie (19 Jul 1917 - 6 Mar 2014) on 14 July 1945 at St. Hubert, SK, and had nine children: Roderic (1946), Norbert (1948), Fred (1949), Honory (1951), Leona (1952), Doreen (1954), Adelin (1956), Patrick (1959), Jeanette (1965)

Main source : Beaujot, Roderic and Beaujot, Elisabeth, 1979. Descendants of/de François and Justine Beaujot : 1860-1979. 


\section{Appendix 3.2}

\section{Sénéchaud family genealogy}

Louis Alexandre Sénéchaud (9 Jul 1856, La Ferrière en Parthenay, FR - Aug 1925) and Justine Léonie née Léau (17 Apr 1861, Parthenay, FR - *) were married on 19 Sept 1880 at La ChapelleBertrand, FR, and had six children: Radégonde, Ernest, Léon, Bertheline, Marcel, Octavie

1. Radégonde Sénéchaud (28 Feb 1882, La Chapelle-Bertrand, FR - 16 July 1960, Parthenay, FR) married Joseph Honoré Largeau (14 March 1881, Mazières en Gâtine, FR - 26 January 1960, Parthenay, FR) on 25 Feb 1908 at Mazières en Gâtine, FR. They had four children:

Bernadette Marguerite Largeau (12 Jan 1902, Pompaire, FR - 12 Nov 1995, Saumur, FR) married Clovis Gagnères (19 May 1902 - 5 Sep 1971), on 24 Oct 1925 in Parthenay, FR. They did not have children.

André Largeau, (22 Nov 1908, Pompaire, FR - 8 Mar 1985, Parthenay, FR) married Marie née Alnet (25 Jan 1910 - 22 Mar 1984) in 1910 at Maziers, FR. They had four children: (Dédé) André Jean-Marie (1931 - 2017), Paulette Renée (1933 - 2020), Bernadette (1946 - 2013), MarieChristine $(1951-2005)$

Raymond Pierre Honoré Largeau, (15 Oct 1910, Parthenay, FR - 4 Aug 1980, Angers, FR) married (1) Germaine Juliette Emilienne née Bernier (4 Aug 1910, Châtillon-sur-Thouet, FR - 28 May 1944, Angers, FR) on 22 April 1933 at Parthenay, FR, and had one son: Bernard Raymond André Largeau (27 Nov 1934, Angers - 28 May 1944, Angers); (2) Germaine née Duveau (30 April 1925, Saint-Sulpice, FR - 20 Oct 2015, Saumur, FR) on 4 June 1946 at Bazouges, Mayenne, FR. They had four children: Christian (1946 - 1956), Maryvonne (1948 - 2016), Denis (1957), Anne (1967)

Marcel Largeau, $\left(1914-{ }^{*}\right)$ married Joséphine née Petit $(1910-*)$ in 1939 . They had three children: Marcel “Petit" (1940 - *), Jacques (1947 - *), Evelyne (1954)

2. Ernest Marcel Léon Sénéchaud (17 Jun 1883, La Chapelle-Bertrand, FR - 28 Mar 1944, SaintMartin-du-Fouilloux, FR) married to Noémie née Pillot (19 Apr 1891 - 13 Aug 1973) on 12 June 1911 at La Peyratte, FR. They had 15 children:

Albert Sénéchaud (2 Jan 1912 - 6 Jan 1985) married Aimée née Pain (12 Nov 1914 - 9 June 1999) on 6 Feb 1937 Lhoumois, FR. They had 9 children: Yves (1937 - 2002), Monique (1939), Maurice (1940 - 1941), Réjeanne (1942), Robert (1943), James (1945), Bernard (1946), Moisette (1948 - 1999), Gilbert (1949) 
Suzanne Sénéchaud (28 Jan 1913 - 1960) married Marcel Ingremeau (* -- *) at Saint Martin du Fouilloux, FR. They did not have children.

Roger Sénéchaud (2 Jun 1914 - 18 Jun 1914)

Alice Sénéchaud (21 Sep 1915 - 2014) married Paul Martin (10 May 1915 - 12 Jun 1986) at Saint Martin du Fouilloux, FR. They had one child: Michel (*)

Raymond Sénéchaud (29 Oct 1917 - 1998) married Marthe née Guillot $\left(^{*}\right.$ ) in 1944 at Saint Martin du Fouilloux, FR. They had nine children: Micheline $\left({ }^{*}\right)$, Claude $\left({ }^{*}\right)$, René $(*)$, Ginette $\left({ }^{*}\right)$, Francis $(*)$, Joël $(*)$, Danielle $(*)$, Madelaine $(*)$, Marie Line $(*)$

Gisèle Sénéchaud (21 March 1920 - 2017) married * Martin and had one child: Mauricette $\left({ }^{*}\right)$. When her husband never returned from the war, Gisèle married Raymond Chambon $\left({ }^{*}\right)$ at Saint Martin du Fouilloux, FR. They had one child: Gilles (*).

Marc Sénéchaud (18 April 1921 - 18 May 1922)

Marcelle Sénéchaud (18 April 1921 - 23 April 1921)

Fernand Sénéchaud (17 March 1923 - 22 February 2019) married Louisette née Thibault (20 January 1931 - 4 July 2016) on 20 June 1959 in Thénezay, FR. They did not have children.

Irène Sénéchaud (5 May 1924 - 2002) married Armand Robert (9 August 1917 - 2010) on 16 Feb 1946 at Thénezay, FR. They had six children: Christian (1946), Christiane (1948), JeanMichel (1950), Colette (1952), Jacques (1960), Isabelle (1964)

Louis Sénéchaud (25 Aug 1925 - 19 Aug 2010) married Paulette née Groleau (*) at Saint Martin du Fouilloux, FR. They had nine children : Jacky $\left({ }^{*}\right)$, Jean-Paul $(*)$, Eric $\left({ }^{*}\right)$, Philippe $(*)$, Patrice $(*)$, Claudie $(*)$, Beatrice $\left({ }^{*}\right)$, Chantal $\left({ }^{*}\right)$, Annie $(*)$

Rémy Sénéchaud (16 Sept 1927 - 27 June 2012) married Régina née David (* LIVING) on 27 Sept 1952 at Chaladray, FR. They had three children: Catherine $\left({ }^{*}\right)$, Françoise $\left({ }^{*}\right)$, Thierry $\left({ }^{*}\right)$

Henriette Sénéchaud (20 April 1929 LIVING) married Paul Molton (13 Feb 1928 LIVING) on 13 January 1951 at Thénezay, FR. They had two children: Dominique (1951), Jocelyn (1954)

Gilbert Sénéchaud (20 Oct 1931 - 2009) married Ginette née Fillon (*). They had six children: Pascal $(*)$, Serge $(*)$, Bruno $(*)$, Dany $(1968-2016)$, Yanic $(*)$, Parni $\left({ }^{*}\right)$

Sénéchaud, still-born child (23 Dec 1933 - 23 Dec 1933) 
3. Léon Henri Sénéchaud (25 Oct 1884, La Chapelle-Bertrand, FR - *) married Marceline née * $\left({ }^{*}\right)$. They had 4 children: Madeleine, Roger, $3^{\text {rd }}, 4^{\text {th }}$

Madeleine Sénéchaud $(*)$

Roger Sénéchaud $(*)$

Sénéchaud, third child $(*)$

Sénéchaud, fourth child $(*)$

4. Bertheline Marie Sénéchaud (4 Oct 1885, La Chapelle-Bertrand, FR - 19 Dec 1955, St. Hubert, SK) married Félicien Beaujot (8 Jun 1878, Malvoisin, BE - 8 Jan 1946, St. Hubert, SK) on 14 Jun 1910 at St. Hubert, SK. They had three children:

Flora Beaujot (25 Apr 1911, St. Hubert, SK - 28 May 1994, Calgary, AB), married Joseph Driscoll (5 Sep 1904, Whitewood, SK - 1 Jan 1972, Kipling, SK) on 20 Oct 1931 at Forget, SK. They had six children: Bertha (1933 - 2008), Joseph (1934), Monica (1935 - 1986), Jack (1938), Leon (1940), Bernice (1950)

Albert Beaujot (1 Apr 1912, St. Hubert, SK - 3 Oct 1988, Calgary, AB), married Grace Pelletier née Beaulac (9 May 1925, Debdon, SK - 28 May 1986, Calgary, AB) on 15 May 1975 in Calgary, AB. They had two children, Alan Pelletier (1959), Leonard Pelletier (1963), and two stepchildren for Albert: Vivian Pelletier (1946) and André Pelletier (1948 - 2005)

Léon Beaujot, (29 Sep 1919, St. Hubert, SK - 28 May 2014, Weyburn, SK), married Dorothy née Mullie (19 Jul 1917, St. Hubert, SK - 6 Mar 2014, Weyburn, SK) on 14 July 1945 in St. Hubert, SK. They had nine children: Roderic (1946), Norbert (1948), Fred (1949), Honory (1951), Leona (1952), Doreen (1954), Adelin (1956), Patrick (1959), Jeanette (1965)

5. Marcel Anathase Sénéchaud (16 April, $1888-{ }^{*}$ ) married Alice Brunet $\left({ }^{*}-{ }^{*}\right.$ ) on 22 Sept 1915 at La Ferrière en Parthenay, FR. It is not known if they had children.

6. Octavie Sénéchaud (2 March 1890, La Chapelle-Bertrand, FR - 5 March 1890, La ChapelleBertrand, FR) 


\section{Appendix 3.3}

\section{Mullie family genealogy}

Jean Louis Mullie (31 July 1845, St-Denijs, BE - 2 April 1919, Cany Barville, FR) married Félicie Julie Marie Delannoy (20 Aug 1849, Messines, BE - 3 Aug 1940, Warneton, BE) on 5 Sept 1876 at Messines, BE, and had eight children: Raymond, Marthe, Paul, Julien, Bertha, Maurice, Emile, Emma

1. Raymond Mullie (16 June 1877, Ploegsteert, BE - 24 July 1951, Wijtschate, BE) married Alide Joyé (11 July 1880, Wijtschate, BE - 12 Feb 1932) on 28 April 1906 at Wijtschate, BE, and had three children:

Louis Mullie (10 March 1907 - 12 Sept 2002) (1) married Marie-Aimée Six (9 May 1909 - 25 Aug 1957) on 10 Feb 1945, and (2) Germaine Verschoore (6 May 1905 - 17 Feb 1990) on 29 Oct 1958. They did not have children.

Jeanne Mullie (7 Feb 1908 - 4 May 1989)

Paul Mullie (10 July 1909 - 24 Aug 1995), married Marie Henriette Windels (15 Sept 1916 - 8 Dec 1999) on 30 Sept 1944 at Celles, BE, and had four children : Monique (1946), Paulette (1946), Marguerite (1947), Elisabeth (1949)

2. Marthe Mullie (24 Feb 1879, Ploegsteert, BE - 8 March 1968, Warneton, BE) married Pierre Devos (8 Oct 1873, Ploegsteert, BE - 14 April 1915, Ploegsteert, BE) on 20 June 1905 in Ploegsteert, $\mathrm{BE}$, and had three children:

Marie-Aimée Devos (6 May 1908 - 27 Dec 2001) married Maurice Vanhove (20 April 1905 - 19 Sept 1971) on 21 Sept 1942 at Ypres, BE, and had three children: Bernard (1944), Stefaan (1945), Monique (1949).

Rosa Marie-Louise Devos (27 Aug 1910 - 1 Jan 2000) married Albert Tougart (4 May 1905 - 10 June 1971) on 8 Sept 1930 at Ypres, BE, and had three children: Alberte (1931 - 2018), Thérèse (1931 - 2003), Pierre (1934 - 1998)

Pierre Devos (1 May 1913 - 29 April 1995) was ordained Jesuit priest at Louvain on 24 Aug 1943

3. Paul Mullie (14 Feb 1881, Ploegsteert, BE - 9 June1967, St. Hubert, SK) married Julienne Smets (2 April 1878, St-Truiden, BE - 12 Nov 1959, Whitewood, SK) on 19 July 1910 in StTruiden, $\mathrm{BE}$, and had five children: 
Marie Louise Mullie, (2 June 1911 - 27 Feb 1992) married Philippe Laforge (8 April 1907 - 10 May 1983) on 11 January 1945 at St. Hubert, SK, and had eight children: Arthur (1946), Thérèse (1948), Cyril (1950), Martin (1952 - 1998), Irène (1954), André (1955 - 2017), Léon (1956) and Monique (1958)

Jean Mullie, (1 May 1913 - 27 May 1929) died at age 16 of appendicitis

Raymond Mullie, (3 May 1915 - 20 Jan 1999) married Maria Smeets (26 Jan 1919 - 3 June 2002) on 19 June 1946 at St. Hubert, SK, and had seven children: Elizabeth (Betty 1947), Jean (John 1949), Bernard (1950 - 2014), Lorraine (1952), Madeleine (1955), Edward (1956), Susan (1957)

Dorothée Mullie, (19 July 1917 - 6 March 2014) married Leon Beaujot (29 Sept 1919 - 28 May 2014) on 14 July 1945 at St. Hubert, SK and had nine children: Roderic (1946), Norbert (1948), Fred (1949), Honory (1951), Leona (1952), Doreen (1954), Adelin (1956), Patrick (1959), Jeanette (1965)

Michel Mullie, (15 March 1920 - 6 Jan 2014) married Jeanne Leconte (12 March 1922 - 6 Aug 2006) on 28 Dec 1944 at Zenon Park, SK and had four children: Roger (1945 - 2020), Armand (1947), Antoine/ Tony (1949), Annette (1953)

4. Julien Mullie (30 Dec 1882, Ploegsteert, BE -7 March 1981, Arborfield, SK) married Marie Louise Duthoit (18 March 1892, Ploegsteert, BE - 17 March 1990, Carrot River, SK) on 11 Feb 1924 at Bailleul, FR, and had five children:

Alfred Mullie (10 Dec 1924 - 21 Sept 2016) married Marguerite Marchildon (29 Sept 1923 LIVING) on 23 Oct 1950 at Lafontaine, ON, and had five children: Marie (1952), Marc (1953), Louise (1955), Claire (1956), Pierre (1959)

Roland Mullie (15 March 1926 - 29 Aug 2010) married Mary Free (26 Sept 1929 - 8 Nov 2010) on 5 Nov 1951 at Arborfield, SK, and had one child: Alex (1953-2019)

Maurice (Felix) Mullie (11 April 1927 - 9 December 2020) had a child with Elsie MacLeod (19 July 1930 - 17 Sept 1992): Garth MacLeod (1964)

Gilbert Mullie (12 Jan 1930 - 20 Oct 2000) married Ruth Frey (5 June 1929 - 6 March 2014) on 28 Dec 1953 at Saskatoon, SK, and had two children: Freddy (1961), Carol (1964)

Joseph Mullie (4 March 1931 - 24 Jan 2005) married Tillie Klotz (2 Dec 1932 LIVING) on 25 Aug 1956 at Vibank, SK, and had five children: Stephen (1957), Adèle (1958), Christine (1962), Jennifer (1965), Paul (1966) 
5. Bertha Mullie (22 Feb 1886, Ploegsteert, BE - 18 Nov 1965, Comines, BE) married Valère Domicent (25 March 1879, Ypres, BE - 31 March 1958, Warneton, BE) on 16 June 1908 and had three children:

Roger Domicent (10 June 1909 - 29 Nov 1985) married Marguerite Lutun (27 April 1906 - 9 Aug 1994) on 17 June 1937 at Warneton, BE, and had three children: Christiane (1941), Yves (1942 2012), Chantal (1944-2014)

Wilfrid Domicent (16 Aug 1911 - 4 March 1994) married Marie-José Boedt (16 June 1914 - 7 April 1973) on 1 June 1937 at Warneton, BE, and had two children: Claude (1939 - 2001), LuC (1946)

Freddy Domicent (7 June 1917 - 23 Feb 1996) married (1) Janine Boedt (30 Jan 1919 - 31 March 1950) on 18 Aug 1943 at Warneton, BE, and had two children: Patrick (1945) and Baudouin (1947), and (2) Thérèse Vanraes (29 June 1924 - 5 June 1978) on 2 June 1951 at Wervicq, BE, and had three children: Anne (1952), Myriam (1954), Frédérick (1955)

6. Maurice Mullie (22 Feb 1886, Ploegsteert, BE - 1 April 1974, aux Loges, FR) married Cécile de La Brosse (21 March 1895 - 2 Sept 1981) on 10 May 1919 at Canny Barville, and had seven children:

Bernard Mullie (1 May 1920 - 27 Sept 2011) married Marie Madeleine Sanson (4 April 1923 31 May 1984) on 10 May 1919 at Cany Barville, FR, and had two children: Françoise (1951), Daniel (1953)

Marie-José Mullie (19 April 1921 - 23 Feb 2008)

Robert Mullie (6 March 1923 - 6 Sept 1998) ordained priest 24 June 1948

Marie-Louise Mullie (17 Oct 1924 - 2 Dec 2007) married Pierre Roland (19 March 1922 - 17 July 1998) on 1 Sept 1947 aux Loges, FR, and had two children: Marie-Annick (1948), Hervé (1952)

Marcel Mullie (13 May 1926 - 20 Nov 2013) married Odile Decultot (8 Aug 1929 LIVING) on 31 Aug 1953 at Gerville, FR, and had three children: Pierre (1955), Dominique (1957), Bruno (1962) Jean Mullie (23 Feb 1929, aux Loges LIVING), married (1) Nicole Sautreuil (28 Aug 1930 - 29 March 2002) on 18 Sept 1954 aux Loges, FR, and had four children: Isabelle (1956), Etienne (1957), Marie-Cécile (1958), Luc (1969 - 1971) and (2) Jeannine Chatelain (28 Sept 1937 LIVING) on 1 Oct 2005 
Elisabeth Mullie (6 Jan 1932 - 6 Jan 1932)

7. Emile Mullie (17 April 1890, Ploegsteert, BE - 8 July 1975, Foncquevillers, FR) married Clémence Lutun (11 June 1899, Lambersart, FR - 11 Nov 1968, Foncquevillers, FR) on 10 Feb 1925 at Merville, FR and had four children:

Thèrese Mullie (17 April 1926 - 5 April 2016) married André Lanthiez (5 Aug 1925 LIVING) on 9 Dec 1950 at Hondainville, FR, and had seven children: Anne (1951 - 2009), Benoite (1953), Fabienne (1955 - 2011), Eric (1956), Myriam (1957), Florence (1960), Blandine (1961)

Pierre Mullie (27 Aug 1927 - 6 March 2009) married Thérèse Chatelain (16 Feb 1932 LIVING) on 15 May 1954 at Fontaine les Croisilles, FR, and had five children: Geneviève (1955), Jean-Xavier (1956), Christophe (1959), Marie-Pierre (1961), Stéphane (1971)

Lucie Mullie (6 Feb 1929 - 28 Nov 1939)

Henri Mullie (1 May 1932 - 10 May 2013) married Renée Reneau (7 June 1935 - 14 June 2019) on 5 Sept 1957 at Cuincy les Douai, FR, and had five children: Marie-Hélène (1958), Vincent (1960 - 1961), Sylvie (1961), Sophie (1963), Laurence (1966)

(...........

8. Emma Mullie (29 Feb 1892, Ploegsteert, BE -27 June 1970, Comines, BE)

\section{Sources:}

Mullie, Jean, 2016. Histoire et Généalogie de la Famille Mullie et de ses alliances. Lulu.com Mullie, Jean, 2019. Histoire et Généalogie de la Famille Mullie depuis 1435. Lulu.com 


\section{Appendix 3.4}

\section{Smets family genealogy}

Jozef Nicolas Smets (2 Dec 1839, Aalst, BE - 18 Oct 1908, St-Truiden, BE) married three times and had children from his first and third spouse. Josef Nicolas Smets was the son of Nicolas Smets (17 May 1793, St-Truiden, BE - 9 Aug 1874, St-Truiden, BE) and Ida Tits (13 May 1798, StTruiden, BE - 23 Nov 1856, St-Truiden, BE). Nicolas Smets and Ida Tits were married in Aalst, BE, on 3 January 1835.

The first marriage was to Jeanne Johanne Mommen (23 Aug 1826, St-Truiden, BE - 21 Sept 1868, St-Truiden, BE) on 30 Jan 1861. The parents of Jeanne were Pierre-Jean Mommen and Marie-Anne Ouwerx dit Ouwerk. Jozef Nicolas and Jeanne had three children: Maria, Jozef, Grégoire (their two sons married two sisters with the name of Fabry).

1. Maria Smets (23 February 1862 - 1 December 1925) became Zuster Adeline, Congregatie du Zusters van Liefde de Gent on 8 May 1882 (Soeur Marie-Adéline des Soeurs de la Charité, known as Tante Nonneke).

2. Jozef Smets (16 April 1864, Sint Truiden, BE - 29 December 1939, Sint Truiden, BE) married Anna Maria Rosina (Meike) Fabry (6 Jan 1862, Sint Truiden, BE - 17 March 1939, Sint Truiden, BE) on 13 Nov 1889 at St-Truiden, BE, and had nine children:

Alphonse Smets (15 April 1891 - 19 Feb 1893)

Maria Smets (10 January 1893 - 9 September 1936) became Zuster Maria, Congregatie du Zusters van Liefde de Gent on in 1918 (Soeurs de la Charité, the same order as her aunt Maria).

René Smets (24 October 1894 - 21 November 1953) became priest in 1920.

Martha Smets (11 September 1896 - 22 May 1963 in Diepenbeek) married Mathieu Schreurs (30 September 1906 - 10 September 1983) on 29 March 1932 (same date as Gaby) in StTruiden, BE, and had two children: René (1933 - 2013), Marie-Louise (1938)

Gustave Richard Smets (1898 - 1899)

Julia Smets (23 January 1900 - 30 June 1906)

Emma Smets (19 December 1900, St-Truiden, BE - 25 July 1988, Hasselt, BE) married Camile Vendrickx (17 July 1898, Alken, BE - 11 May 1965) in August 1925 and had two children: Luc (1926 - 1992, ordained priest in 1951) and Lutgarde (1928 - 2019) 
Gabriel [Gaby] Smets (16 July 1903 - 5 September 1980) married Paul Lavigne (7 March 1910 19 December 1976) on 29 March 1932 in St-Truiden, BE (same date as Martha). They did not have children.

Marcel Smets (1 April 1905 in St-Truiden, BE - 22 December 1988, St-Truiden, BE) married Paula Maleux (8 Nov 1912 - 15 Nov 2009) on 22 May 1933 in Borlo, BE, and had nine children: Yolande (1933), Christiane (1935 - 1935), Luk (1935), Guy (1937), Jaak (1939), Klara (1940), Ria (1942 - 1986), Simone (1945), Lutgarde (1948)

3. Grégoire Smets (4 March 1866, St-Truiden, BE - 18 July 1935, St-Truiden, BE) married Marie Christina (Stina) Fabry (18 February 1865, Sint Truiden, BE - 21 July 1940, St. Truiden, BE) on 12 Dec 1889 in St-Truiden and had seven children:

Josef Smets (17 Nov 1890, Diepenbeek, BE - 25 May 1966) married Anna Jérome (7 August 1898 - 4 December 1971) circa 1923 and had two children: Christiane $\left({ }^{*}\right)$ and Anna $(*)$.

Jeanne Anne Maria Smets (7 April 1893, Diepenbeek, BE - *, Zepperen, BE) did not marry Jean Joseph René Smets (7 Feb 1895, Diepenbeek, BE - 12 May 1966) married Simonne Rousselet $\left({ }^{*}\right)$ circa 1927 and had two children: Jean $\left({ }^{*}\right)$ and Nicole $(*)$.

Anna Smets (7 Aug $1898-{ }^{*}$ ) married Joseph Mangon $\left({ }^{*}\right)$ circa 1932 and had one child: Suzanne $(*)$

Marie Louise Henriette Séraphine Smets (2 April 1900, St-Truiden, BE - * ) married Lambert Dantoin $(*)$ circa 1925 and had * children

Marie Léonie Marthilde Smets (2 May 1902, Zepperen, BE - 9 Jan 1907, Zepperen, BE)

Virginie-Antonie Smets (18 April 1906, Zepperen, BE - *) did not marry

The second marriage was to Cathérine Mommen (30 April 1831 - 6 Oct 1870), sister of his first wife, on 20 Oct 1869, there were no children.

The third marriage was to Maria Philomena Penxten (dit Pexhen-Peyshen) (17 or 23 Oct 1839, Alken, BE - 25 Nov 1903 at 25 rue des Moutons, St. Truiden, BE) on 26 October 1871 in Alken, BE. Maria's parents were Engelbertus Penxten dit Peyschen (1792 - 1880) and Maria Ide 
Vanvinckenroy (14 June 1794 - 20 July 1852). Joseph and Maria had six children: Thérèse, Antoine, Matilde, Julienne, Josephine and François.

1. Thérèse Smets (5 September 1872, St-Truiden, BE - 10 November 1946, St-Truiden, BE), did not marry

2. Antoine Smets (31 May 1874, St-Truiden, BE - 24 Nov 1929, St-Truiden, BE) married Jeanne Cox (18 May 1882 - 7 Jan 1933) on 16 July 1914 at St. Josse Ten Noode, BE, and had three children: Jean $(*)$, Jackie $(*)$, Jacqueline/Jackie $(*)$

Jean Smets (15 June 1915, St-Truiden, BE - *) married circa 1939 and had one child: * (born circa 1940)

Jackie Smets (22 Sept 1918, Sint Truiden, BE - 8 Nov 1918, Sint Truiden, BE)

Jacqueline (Jackie) Smets (17 March 1922, Sint Truiden, BE - circa 1995-2000) married Robert Delespesse circa 1947. They did not have children.

3. Matilde Smets (19 August 1876, Sint Truiden, BE - 25 March 1943, St. Truiden, BE), did not marry

4. Julienne (2 April 1878, St-Truiden, BE - 12 Nov 1959, Whitewood, SK) married Paul Mullie (14 Feb 1881, Ploegsteert, BE - 9 June1967, St. Hubert, SK) on 19 July 1910 in St-Truiden, BE, and had five children:

Marie Louise Mullie, (2 June 1911 - 27 Feb 1992) married Philippe Laforge (8 April 1907 - 10 May 1983) on 11 January 1945 at St. Hubert, SK, and had eight children: Arthur (1946), Thérèse (1948), Cyril (1950), Martin (1952 - 1998), Irène (1954), André (1955 - 2017), Léon (1956) and Monique (1958)

Jean Mullie, (1 May 1913 - 27 May 1929) died at age 16 of appendicitis

Raymond Mullie, (3 May 1915 - 20 Jan 1999) married Maria Smeets (26 Jan 1919 - 3 June 2002) on 19 June 1946 at St. Hubert, SK, and had seven children: Elizabeth (Betty 1947), Jean (John 1949), Bernard (1950 - 2014), Lorraine (1952), Madeleine (1955), Edward (1956), Susan (1957)

Dorothée Mullie, (19 July 1917 - 6 March 2014) married Leon Beaujot (29 Sept 1919 - 28 May 2014) on 14 July 1945 at St. Hubert, SK and had nine children: Roderic (1946), Norbert (1948), 
Fred (1949), Honory (1951), Leona (1952), Doreen (1954), Adelin (1956), Patrick (1959), Jeanette (1965)

Michel Mullie, (15 March 1920 - 6 Jan 2014) married Jeanne Leconte (12 March 1922 - 6 Aug 2006) on 28 Dec 1944 at Zenon Park, SK and had four children: Roger (1945 - 2020), Armand (1947), Antoine/Tony, 1949), Annette (1953)

5. Marie Gertrude Josephine (12 May 1880, St-Truiden, BE - 25 Jan 1959, Londerzeel, BE) married Jules Joseph Hubert Dutois (27 April 1876, Uyckhoven BE - 10 Dec 1936, St-Truiden) on 19 July 1910 in St-Truiden, BE, and had four children:

Paul Dutois (10 May 1912 - 1997) married Lucie Deckers (1912 - 1997) circa 1937 in Limburg. They did not have children.

André Joseph Michel Dutois (17 June 1914, St-Truiden, BE - 2 May 1989, Tongeren, BE) married Barbe Odile Octavie Germaine Pexsters (9 Feb 1917, Aalst, BE - 16 Dec 2006, Hasselt, BE) on 12 August 1942 in St-Truiden, BE, and had two children : Jenny Joséphine Ghislaine Raphäelle (1945) and Maggy Gabrielle Myriam (1950)

Marie-Louise (Malou) Dutois (14 Aug 1916 - 27 July 1989) married Edmond Jozef (Jos) Weets (30 Sept 1916 - 13 Sept 1984) on 3 April 1945 in St-Truiden, BE, and had six children : Hugo (1946), Ria (Maria, 1947), Luk (1948), Paul (1950 - 1950), Godelieve/Lieve (1951), Paul (1955)

Lucien Dutois (13 July 1919, St-Truiden, BE - 3 March 2012, Alken, BE) married Simone Jamaer (10 Jan 1922, St-Truiden, BE - 6 Feb 2007, Alken, BE) on 15 August 1948 and had one child : Paul (1957)

6. François Louis Alphone Smets (26 Sept 1882, St-Truiden, BE - 6 March 1953, Aldenneik, Maaseik, BE) married Marie-Henriette Hélène Thyssen (28 Nov 1882, Luik, BE - Feb 1955) on 14 Oct 1926. They did not have children. 


\section{Chapter 4}

\section{Leon Beaujot and the family of Félicien and Bertheline (née Sénéchaud) Beaujot}

Among the four parents of Leon and Dorothy Beaujot, Félicien Beaujot was the first to arrive in Canada, in 1892 and Bertheline Sénéchaud was the second, in 1910. The Beaujot family was among the original families to come to Saint Hubert, Saskatchewan, then called La Rolanderie, of the Assiniboia District of Canada's North West. In his book on Canada: Immigration and Colonization 1841-1903, Norman Macdonald (1966) uses the chapter title "Years of frustration, 1867-1894". In effect, the first 30 years after Confederation was a time of considerable efforts to attract immigrants but with fewer arrivals than departures, especially toward the United States. Nonetheless, there were the beginnings of European settlement in the Prairies, including La Rolanderie, described by the historian Cornellius Jaenen (2011: 102-105) as a "Utopian Settlement."

\section{Félicien Beaujot (father of Leon Beaujot)}

At the outset, the Beaujot family was associated with the French counts who had arrived as of 1885 . The widowed Justine Beaujot, mother of Félicien, was housekeeper to the priest, with the rectory being at Bellevue, the former home of Count Yves de Roffignac. Félicien and his brother Eugène, as well as their sisters and their husbands, Céline and Joseph Pirlot and Joséphine and Adolphe Gatin, worked for the Counts Claude Alexis Joseph de Langle and Paul de Beaudrap de Denneville. In 1912 the Gatin family purchased the La Rolanderie property that had given its name to the district.

The Beaujot family had come from the Namur province of Belgium. They had operated the Cherzy Mill ${ }^{1}$ in Gedinne from the time of their marriage in 1860 until about 1869. Then François Beaujot, Félicien's father, was an egg merchant at Patignies and Malvoisin. The family arrived in Saint Hubert on 27 March 1892 when François was 69 and Justine was 56. Félicien's sister Léopoldine was already married to Léon Poncelet and living in Malvoisin. His sister Marie returned to Belgium in 1896 and married Marcellin Godart; they lived in Patignies. ${ }^{2}$

Félicien, born on 8 June 1878 in Malvoisin, Belgium, was the youngest in the family, aged 13, when they arrived in Canada. By the time he was 15, he was working for Count de Langle and he became particularly adept at looking after horses, including training them, herding wild horses, helping with the birth of colts, and wintering horses in the Moose Mountain district. Around 1900, his older brother Eugène established a homestead (SW 36-14-3-2 West of $2^{\text {nd }}$ Meridian), where they lived with their mother. At the request of his mother, Félicien returned to Belgium in the winter of 1903-04 to encourage his sister and brother-in-law Joséphine and Adolphe Gatin to return to Canada. They returned together, arriving in Saint Hubert on 10 April 1904, a month before their mother's death on 8 May 1904. It was also in 1904 that Félicien purchased the east half of 35-14-3-2, adjacent to that of his

\footnotetext{
${ }^{1}$ See Chapter 3 for description and location of the Cherzy Mill.

${ }^{2}$ See Chapter 3 for further details on the Beaujot family of origin.
} 
brother Eugène, with Joséphine and Adolphe Gatin subsequently purchasing the adjacent NW quarter of 36-14-3. All three farms are within two miles of where the Saint Hubert Church now stands.

The $4^{\text {th }}$ Census of Canada 1901 lists the two brothers and their mother in the Whitewood Sub-District of Assiniboia East, North West Territories: Eugène aged 35, Félicien (incorrectly spelled as Felice Beaujet) aged 22 and Justine aged 65. Their country of birth is indicated as Belgium, with immigration year 1892, naturalization in 1900, "Belgian" as the racial or tribal origin, Canadian nationality, Roman Catholic religion and "farmer" as profession or trade for the two brothers. All three are indicated as French mother tongue with ability to read and write, and ability to speak French, with only Félicien having the ability to speak English ${ }^{3}$.

In 1906, a mid-decade census was established to document the rapidly growing population of the Canadian Prairies. Saskatchewan was now a province. Eugène, Félicien and Joséphine's families are listed in three separate households ${ }^{4}$. Their postal address is listed as Whitewood. Their place of birth is incorrectly indicated as France (it should be Belgium). Félicien is on 35-14-3, having 6 horses, 2 milk cows, and 11 other cattle. Eugène is on 36-14-3 with 9 horses, 7 milk cows, 8 other cattle and 1 hog. The Gatin family is on 36-14-3 with 2 horses, 4 milk cows, 2 other cattle and 2 hogs.

\section{Bertheline Sénéchaud (mother of Leon Beaujot)}

Bertheline Sénéchaud was born on 4 October 1885 at La Peyratte, near Parthenay, France. She was fourth of six children born to Louis Alexandre Sénéchaud and Justine Léonie (née Léau). She was baptized at La Chapelle-Bertrand, the adjoining commune, where her parents had been married on 19 October 1880 . The family were farmers in the commune of La Peyratte. ${ }^{5}$ At the age of 24 , possibly seeking to escape a life of looking after her parents, Bertheline left La Peyratte. Since her parents were very opposed to their daughter's departure, she left unannounced, under the deception of going to wash clothes on the shore of the Thouet River.

Bertheline's route from La Peyratte to Saint Hubert is not fully known. The promise of marriage, dated 28 May 1910, gives her parish of origin as Pompaire (Deux Sèvres) in the Diocèse de Poitiers, France. It may have been in Pompaire, $12.5 \mathrm{~km}$ from La Peyratte, that she worked as a maid to pay for her passage to Canada. She would have been in contact with Father Jerôme Boutin, who had been the priest at Saint Hubert since 1903 and whose brother Victor and Hélène Boutin had come to Saint Hubert from

\footnotetext{
${ }^{3}$ See www.automatedgenealogy.com for North West Territories, District of Assiniboia East, Sub-District of Whitewood, page 19, lines 22-24.

${ }^{4}$ See www.automatedgenealogy.com for Saskatchewan, Assiniboia East, Sub-District 25 (townships 13 \& 14 in ranges 1, 2, 3), page 15, lines 37, 38, 40 and page 16 lines 1-3.

${ }^{5}$ The farm at La Peyratte is described in Chapter 3 (see Ernest and Noémie Sénéchaud). It was located near the lieu-dit called "Le four" that is also called "Le Panier Fleuri" after the name of a restaurant by this name that was once at this corner about halfway between La Chapelle-Bertrand and La Peyratte. Le four is located on the right (west) side of Route Nationale 149 going from Parthenay to La Peyratte, just before Route Départementale 165 that joins La Peyratte and La Chapelle-Bertrand. The farm would have been on the east side of D165, at this same corner. There is a short dead-end road and one can see the present farm some 200 meters beyond the fence.
} 
Pompaire in $1908^{6}$. It is through the Boutin family that Bertheline came to correspond with her future husband, Félicien Beaujot.

Bertheline was a passenger on the SS Corinthian 2, leaving from Le Havre on 25 April 1910 and arriving in Quebec City on 9 May 19107. Bertheline's destination is shown as Whitewood, Sask. She is shown as single, with the intention of permanently settling in Canada, able to read and write, and her intended occupation in Canada was listed as "domestic". The document also indicates that she had $\$ 40.00$ in cash and it is stamped as "Continental Bonus Allowed" which would have paid for about a quarter of the $\$ 25.00$ cost of the trans-Atlantic trip on third class. The train from Quebec City to Whitewood would have cost about $\$ 15.00$, and taken about four days to travel the $2,800 \mathrm{~km}$. When Bertheline arrived in Saint Hubert, her parents were delighted to hear from her again through the Boutin family. It is also remembered that her skin had become very dark on the boat trip across the Atlantic. A dark complexion is characteristic of some members of the Sénéchaud family and their descendants.

\section{Saint Hubert, 1910-1919}

With Bertheline's arrival in Saint Hubert on about 15 May 1910, and the announcement of their marriage on 28 May, Félicien and Bertheline Beaujot were married on 14 June 1910 in Saint Hubert. In her "Memories," their daughter Flora Driscoll (1992) writes that it snowed on their wedding day. Flora also has a picture (p. 5) of the house on top of the Pipestone Valley (S.E. 1/4 of 35-14-3-2) where they lived on the farm that Félicien had established next to his brother Eugène. It was a three-room house, made of wood and painted white, consisting of a kitchen and two bedrooms. Their three children were born there: Flora on 25 April 1911, Albert eleven months later on 1 April 1912, and Leon seven years later on 29 September 1919. Flora Driscoll (1992: 5) also writes that her mother was assisted by a Métis midwife at the birth of her first child. This would have been Marie Adele Bellehumeur (see Memories of Saint Hubert 1980: 62).

In writing about her childhood, Flora first recalls the following story:

My first engraved memory of danger was when Dad hitched up the horses on the binder (used for cutting the crop and tying the grain into bundles or sheaves). He had not put the binder in gear in order not to spook the horses. As they were going around in a circle, the bull wheel fell into a badger hole and it set the gear, spooking the horses. Mom had been standing there holding Albert (three years) and I (four years) in each hand when the horses took off. Dad fell off the binder but kept a hold of the reins and was being dragged when he yelled for us to get into the house. Once we got in the house he let go of the reins and the horses took off into a bluff ( $a$ clump of trees).

\footnotetext{
${ }^{6}$ Victor and Hélène Boutin had come to Saint Hubert from Pompaire in 1908. They had two children. Their son Maurice was 16 when they came to Canada; in 1919 he married Armandine Jeannot. Their daughter Bernadette was born in 1903 and married Emile Gatin in 1924. This early contact between Bertheline and the Boutin family brought continuing relationships across these families.

${ }^{7}$ See the Sénéchaud section of Chapter 3 for further details on the SS Corinthian and on Bertheline's status as a passenger.
} 
Félicien built a walking bridge across the Pipestone creek so that Flora and Albert could go to school in Saint Hubert in 1918, when they were seven and six years old. They were joined by their cousins Marcel and Mathilde Payot who lived on the adjoining farm. Flora recalls that there were 30 children at the school, and that the teachers were nuns who spoke French. There was only one English family at the school. When she was eight, Flora was at the convent so that she could qualify for first communion. They slept in the basement of the old church, sleeping two to a single bed. Flora continues:

The convent was very strict, and we all had our chores to do. The only fun we had was when they poured the wash water from the laundry down a hill behind the church. We could slide down it on old cardboard boxes or in old tubs, whatever worked.

On the farm, the children could raise a little money by collecting gopher tails and crow's eggs. The municipality paid three cents per tail and five cents per egg because these were pests for the crops and for other birds. Using syrup pails, Flora and Albert would take water from the creek and pour the water into gopher holes to flush out the rodents that they would then "bonk them on the head to kill them before pulling their tails off." The children would climb trees to collect crow's eggs.

\section{California, 1920}

When Leon, their third child was born, on 29 September 1919, Félicien was 41, Bertheline was 33, and Flora and Albert were aged eight and seven. Félicien suffered from debilitating migraine headaches that would sometimes bring him to the point of vomiting or passing out. A doctor had advised that he would be better off in a lower altitude climate, closer to the ocean. He took a trip on his own to Sacramento California to see if it would make a difference. In effect, once he had passed the Rocky Mountains the migraines stopped. He decided to move his family to California. They sold their farm to Joseph and Joacine Girard (née Havelange) and purchased a small poultry farm and orchard in Freestone, California ${ }^{8}$. They left on 2 January 1920, in weather of minus 35 degrees Fahrenheit, taking the train at Whitewood.

When they arrived in Sacramento, the Spanish flu was raging. The Spanish flu pandemic is estimated to have caused over 25 million deaths worldwide, far in excess of the 9 million deaths of the Great War (Crosby, 2003). ${ }^{9}$ Bertheline was especially affected because she had previously suffered from the flu in Saint Hubert, losing a lung. The whole family was affected, except Leon who was only four months old at the time. While his mother was in hospital and close to death, Leon was passed from one family to the next and they almost lost track of him, as successive families succumbed to the flu. When visiting in the Sebastopol area with Jack Driscoll, Flora and Albert said that baby Leon was moved from neighbour to neighbour in order to prevent him from acquiring the flu, and it apparently worked.

\footnotetext{
${ }^{8}$ The location is now called Freestone Vineyards, where there is a sign for Freestone Historical District and a woodfire bakery and winery at the same intersection (Leona and Russell Fry visited Freestone in 2011). ${ }^{9}$ Cameron (2020) estimates 5,000 Spanish Flu deaths in Saskatchewan. The first wave, in the spring of 1918, was mild, but by October there were lockdowns, forbidding gatherings and closing theatres, schools and churches. However, the end of the war in November brought celebrations and a more deadly second wave.
} 
When Félicien got out of the hospital, he sold the farm, found work at a laundry and bought a house closer to the Sebastopol hospital where Bertheline remained until spring. Flora and Albert went to school at Sebastopol, where they were taught in English. The doctors advised that the climate was too humid for Bertheline to ever completely recover from her illness. The family made a sacred promise that if everyone recovered, they would come back to Saint Hubert. In the summer of 1920, the family returned by boat to Vancouver then by train the rest of the way to Whitewood. The migraine headaches also returned.

\section{The Daley farm, 1921-27}

The hospital bills, and the failed attempt to establish themselves in California, had brought financial disaster, with the family effectively losing all their savings. On return to the Saint Hubert district, they first lived in the two room ex-postal shack called the Laradde house, then they put a down payment on the Jack Daley farm five miles southwest of Saint Hubert (SW 25-14-4). This was only a quarter section, but they still had to have a large mortgage on the property.

Albert was a joker from a young age. One of the tricks he liked to play was to knock on the door, then hide before his mother would come to see who was at the door. Having tired of this trick, on hearing a knock, his mother decided to come to the door wielding a butcher knife to teach her son a lesson. However, this time it was their neighbour, George Cross, who had knocked. There they were both stupefied and Bertheline was unable to explain herself to the English-speaking Mr. Cross!

Flora and Albert went to Lansdowne School ${ }^{10}$, a distance of four miles, and at Pipestone School, at a similar distance. Flora continues (1992: 7):

I remember crying because Dad pulled me out of school when I was twelve or thirteen in Grade

7 because he wanted me to help on the farm. I had really wanted to finish school and become a nurse. He thought Albert should stay in school because he was a man and yet Albert hated school (this was probably Albert and I's first experience of sexual discrimination, we both lost out).

Reflecting on this time when he was at pre-school ages, Leon says: While my father had a very difficult life, I still remember how good he was to me when I was a child. When I was five or six, he would take me with him to the fields. When raking hay, I would sit at his feet on a small seat that he had installed. By the end of the day, I was as dusty as he was. When he was sowing wheat with four horses and a drill that was ten feet wide, we would stand on the platform behind the boxes containing the grain. He would control the horses from the side that was closest to the previous row, and at the end of the field he would pull the leaver that took the discs out of the ground, turn the implement around and we would

\footnotetext{
10 The Lansdowne School opened in 1886, in a log structure built on SW 22-14-4 that served the community until 1896. When Flora and Albert Beaujot were at the school, it would have been on NE 16-14-4. In 1927, a new school was built on NE 9-14-4, closing in 1959 (Kipling and District History Book Committee, 1998: 117-118).
} 
switch positions so that he could once again be on the side closest to the previous planting. He could sow 20 acres in a good eight-hour day, with a rest for the horses at lunch time. It seems my father was not affected by mosquito bites. I remember him coming home with arms full of blood after he had been in the fields all day with the horses.

\section{Handsworth, 1927-34}

There were good crops in the 1920s, but Félicien was still sick and the family was not able to make the payments on the farm. The family decided to leave the Daley farm and move to the Handsworth area where the land was a good price at that time. They arrived on 27 March 1927. With all the moves and the father's sickness, the family was very poor. They made a down payment on a half section of land ${ }^{11}$ located six miles east of Handsworth, built a small house and brought the land under cultivation ${ }^{12}$. Water was never located on this farm, in spite of some twenty attempts to dig a well. Flora and Albert did not continue their schooling. They helped on the farm and Flora was hired out as a housekeeper, caregiver and general helper to several of the neighours.

Leon says: Handsworth had "everything", a garage, post office, store, community hall, plus 10 to 12 families living in town. We did not go further than that in those days. The priest came from Forget to say mass at the school once per month. Forget was 12-14 miles away, by a prairie trail. Sometimes we went there for church in the summer.

The family had 10 to 12 horses and some 20 to 25 cattle, including 5 or 6 milk cows. Félicien and his family raised horses to sell as colts. They also broke-in horses that were four to five years old, for ranchers who wanted their horses trained. These were worked for a year then returned to the ranchers. From his experience when working for the counts, Félicien had become very adept at handling horses. ${ }^{13}$ He would do veterinary work for the neighbour farmers. He had special equipment to throw a horse for castration. He would take advantage of stud horses whose services were paid based on successful breeding. Since they did not have a bull, the cows in heat that were to be bred were walked behind the wagon to a neighbour bull. This was free, and the bull did not seem to mind.

From the milk, Bertheline made butter which was exchanged for supplies at the grocery store. She was also in charge of the chickens, and very much liked her hens. Very few purchases were made at the Handsworth grocery store: flour, sugar, salt and pepper, yeast, coffee, tea, macaroni, very seldom

\footnotetext{
${ }^{11}$ Félicien had owned a half section (NE and SE of 35-14-3-2) east of Saint Hubert from 1904 to 1919, then a quarter section (Daley farm SW 25-14-4) west of Saint Hubert, before moving to the half section in the Handsworth area. A half section (320 acres) is larger than the average size of farm holdings for Saskatchewan in 1901-11 (285.1 and 295.7 acres respectively), but lower than the average acres in 1921-26 (368.5 and 390.0 respectively). See Statistics Canada, 1983: Series M12-22 and M23-33).

${ }^{12}$ Directions to Handsworth farm and Flinton School from Kipling: Go west of Kipling on No. 48 to $1 \mathrm{~km}$ from Windthorst, take the Windthorst Road to the south for 17 miles to the correction line which is also the end of the road. On the correction line, go west $2.0 \mathrm{~km}$ to get to the homestead: there is an approach off the road into the field, see a bush with one evergreen and some caragana, the house and barn were on the knoll that can be seen directly in the field, to the east of the bush. From that same corner of the correction line and the Windthorst Road, go east $0.5 \mathrm{~km}$ to get to the site of the Flinton school, see marker in the previous school yard.

${ }^{13}$ The Saint Hubert book carries a picture of Félicien with his dog "Pirame" taken in 1915 (p. 59).
} 
vegetables or fruit. Leon continues: In the summer, we would eat fresh chicken, and pork that was kept in salt brine. In the winter, we could eat beef that was kept frozen. Chickens were also preserved in sealers. There was a big vegetable garden with potatoes, carrots, onions, cabbage, cucumber, peas and beans. When it was dry, we would take empty barrels to the dam and fill them for watering the garden. Mother would preserve peas, beans, pickles and wild fruit, especially Saskatoon berries, and make jam. She also made her own soap, purchasing the lye and mixing it with lard from an animal, warming it up, then laying it out and cut into pieces after it had hardened. Heating was mostly with wood, and some coal. We ordered some clothes from the Eaton catalogue and made other things ourselves.

In the fall of 1927, Leon went to Flinton School which was located 2.5 miles east of their home. In the winter, the climate was so cold that his parents decided to put him in residence at the Forget convent for the remainder of that year, and to prepare for his First Communion. Flora, at age 16, was employed by the convent to pay for Leon's schooling. This was not remembered as a very good experience. Quoting Leon:

I was so lonesome, not even being allowed to see my sister who was working there, and I did not learn much because I was so afraid of doing something wrong and getting the strap. The nuns were particularly mean to the older boys who would really get a pounding, especially if they fought back.

The remainder of Leon's schooling was at Flinton, to which he rode on horseback, but he had to walk when the horses were at work in the fields. In the spring of 1935, Leon graduated from grade 8 , though he had only been at school for a total of seven years. He continues:

I liked school, and I was very interested in history, geography and math, though I was also quite good in spelling, but writing never came easily.

I was back at the Forget convent when I was preparing for confirmation at about age eleven or twelve. I was with Dan Driscoll and his sister Vicki. Dan and I managed to tell Vicki that we were going to escape. We did this by convincing the postman, whom we knew from Handsworth, that we were to get a ride home with him. The ruse worked, and I had to walk the last 2.5 miles home. While my parents scolded me, they seemed to understand and never sent me back. This deception and missing a week of catechism did not prevent me from being confirmed, as scheduled.

My first teacher at the Flinton one-room school was Grace Roluf, she taught me English. There were about 30 students from grades one to ten. For two or three years, Annie Todd-Gray was the teacher and she was very interested in baseball. She would cancel the afternoon recess so that we would have an extra half hour of ball practice at noon. Two years in a row, we came in first among the six surrounding schools. We were about half boys and half girls, aged 11 or 12 to 14. I was pitcher or playing second base. We raised money to pay for the team shirts by selling gopher tails, crow eggs and magpie eggs, at five cents or ten cents each.

Leon was interviewed about his time at the Flinton School when the building was lost in a fire on 1 May 2009. The article in The Kipling Citizen shows a picture of the nine players of the softball team, with Leon 
Beaujot shown as the fourth player from the left (Thom, 2009). The school had been built in 1917, and it operated as a one-room school until 1947 when it became a Community Centre (NW 31-10-6). Besides being a school, there were a variety of events including dances, concerts, fairs, Christmas celebrations, funerals, church services, and later bingo, picnics and turkey shoots. "At Flinton they always had really good Christmas concerts and dances" said Leon. "The biffies (toilets) were out in the yard!" At lunchtime, the students also tended to their horses, which was their source of transportation. Leon recalled his first lesson in English, an often-repeated story: The kids used to say 'may I leave the room' to go to the bathroom. They said it so fast - so I started saying 'may I get the broom' and it worked for a while, until the teacher got him to say it more slowly, and after a good laugh he got it right.

Leon continues with various memories from the years when he was growing up in Handsworth:

The population of the Handsworth area was largely of German, Irish and Hungarian origins. There was no Catholic Church, but a priest came once per month to say mass at the school. Forget was some 12-14 miles, and we would mostly go to church there in the summer. We had a car for a while, but mostly we travelled by horses. There were no churches in Handsworth, but the people were very religious and there were strict rules against even playing ball, swimming or playing cards on Sundays. Some families did not even allow children to play catch on Sunday. The Beaujot yard was a less sacred ground for young people to gather, hiding from their parents as they practiced their baseball.

The first trip that I remember in a car was when I was seven or eight, thus about 1927. My brother Albert had broken his ankle and was in hospital at Arcola. I went with my Dad to visit, getting a ride with a neighbour who had a Ford Model A. We had a Model T for a while, it had a canvas top and fold-up windows made of light leather. The car was run for two years, then it was converted into a Bennett Buggy that was pulled by horses. ${ }^{14}$

I remember my mother getting her first washing machine. The handle had to be pulled back and forth to rock a tub containing the clothes. There was no "ringer" to press the water out of the clothes. Two of us would twist the sheets in opposite directions to take out the water before they were hung to dry.

We always had cats and dogs, but they were never allowed in the house. I remember one dog in particular who could bring the cows in for milking, and who also would play ball with me.

There were 28 children in my school and a quarter did not know English when they started. Plus, the teacher had to help the high school students with their correspondence courses. Yet she spent time with me to help me to learn English. One year, I dislocated my shoulder and had to stay home in bed rather than go to school. I received 31 Valentines cards from the kids at school.

One of first jobs I remember doing was to straighten old nails so they could be re-used. I remember this whole pail of crooked nails that kept me busy for days on end.

\footnotetext{
${ }^{14}$ Richard Bedford Bennett was Prime Minister of Canada in 1930-35 and he was blamed for the difficult economic conditions that forced people to abandon their cars, converting them into horse drawn carriages that were called Bennett Buggies.
} 
At Handsworth, the farming conditions kept getting worse. By the early 1930s there were dust bowl conditions, compounded with grasshopper infestations. The blowing dust was so severe that it would cause blackouts. It was not as dark as at night, but the dust would block out the sun. Some years there was so little rain that Bertheline would say that there had hardly been 'quatre gouttes en croix' (that is, hardly enough to make a cross with the four drops that had fallen). The family would place wet rags in the cracks of the house to prevent the dust from coming in.

In about 1930 the grasshoppers got the remaining crop. I remember watching the grasshoppers come in, blackening the sky. We had gone to Forget with our Model T Ford. As we were coming back, we could see that everyone was looking up as the sun was blanking out with grasshoppers flying overhead. When we got home, they were landing in the fields. I remember my Dad being beside himself to see the fields being destroyed. He got a mower from the neighbor and Albert and Dad started mowing the field of oats to at least have some hay. As they were going around, the grasshoppers moved to the centre of the field. By the time the mower got to the centre, there was nothing left standing, the grasshoppers had eaten everything, and they were even eating the cut crop.

There was a municipal/provincial government program giving insecticide to spread along the roadways for grasshopper control, but it did not seem to make much difference. One year, we fed the cattle only with Russian thistles. They survived but it sure was messy milking them with their severe diarrhea. The prairie wool grass was particularly vulnerable to fires in dry conditions. In about 1928-29, I remember my sister Flora coming home all black with singed hair from helping to fight a fire.

We never had much luck with crops at Handsworth. Already in 1927 there was a drought, and we never had a proper crop. My father's health was poor, and in effect I cannot remember a time when he was completely well. In Handsworth, father was still making the farm decisions, but not after we left in 1934 . When we moved back to St. Hubert in the fall of 1935 , he was pretty much out of it.

\section{Flora and Joseph (Joe) Driscoll}

While they were living in the Handsworth area, Flora met Joseph Driscoll whose family had moved from Percival near Whitewood, purchasing land in the Handsworth district. There is an entry on James Driscoll, the father of Joe, in Memories of St. Hubert 1980. James had arrived in Whitewood from Ontario on 18 March 1893, a year after the Beaujot family had come to Saint Hubert. In the summer of 1927, Flora was fetching water from a slough for the garden. She had a team of horses hitched to a "stone-boat" which she would drive into the slough to fill the large barrel with water. For some reason the horses got separated from the "stone-boat" and left Flora stranded in the slough. As she was walking out of the slough, totally drenched, up rode Joe Driscoll. This first encounter of the future couple was often recalled with a good laugh.

Flora and Joe were married in the Catholic Church in Forget, Saskatchewan on October $20^{\text {th }}, 1931$. When they got married, Joe had five horses and a cow. He had a rumble seat Model T coupe which he converted into a two-wheeled Anderson cart, since Flora and Joe could not afford gasoline. Their first two children, Bertha and Joseph James, were born while the Beaujot family was living in the Handsworth area. In comparison to the Beaujot farm which lacked a supply of water, the Driscoll farm was closer to 
the Moose Mountain, and they always had water and pasture for the cattle and horses. Nonetheless, Flora Driscoll (1980) writes in Memories of St. Hubert 1980:

We were married in 1931 at the start of the depression. That winter there was no snow and we drove the wagon all winter. Between four years of drought, grasshoppers, rust, and frost, there were no crops for eight years. The dust blew every day and there was no rain or snow for four years in a row.

We lived in a granary twelve by twelve feet, lined with cardboard for the first two years of our marriage, south of Flinton School on a rented quarter section. Due to lack of space, Bertha was born at her Grandma and Grandpa Beaujot's house on 1 April 1933. That summer we moved and rented a half section of 34-10-6 in a two-room log house which was full of bed bugs and rats. Joe and Monica were born there in 1934 and 1935.

In 1936 we left the bed bugs and rats and rented the half section of 36-10-6 from John Shields who was retiring. It had a two-bedroom house, plus a share on sheep, and cattle. At the time the highest price you could get for a good two-year-old steer was sixteen dollars; wheat was ten cents a bushel; barley eight cents; oats six cents; cream at three dollars for a five gallon can, and eggs six cents a dozen.

Jack was born in 1938 and Leon in 1940. All work was done with horses. In the year 1942, we sold four two-year old heifers for a total of forty-eight dollars for a down payment on the half section 34-10-6 and South half section 33-10-6, all West of $2^{\text {nd }}$ Meridian.

\section{Up north: Amsterdam, 1934-35}

In 1934, some 41 families left the Handsworth area, representing about half of the population. A government program was established to move livestock and machinery out of areas that were particularly affected..$^{15}$ The prolonged drought made for dust bowl conditions and lack of feed for livestock ${ }^{16}$.

Leon continues: In the summer of 1934, Albert went North to make hay, and called to say that the crops were good there. He said he could ship the hay to Handsworth, or they could take advantage of a government program to move out of the Handsworth district. When we left Handsworth, my parents both had to sign a 'quit claim' indicating that they were abandoning the farm and all the possessions which they were leaving behind.

I was 14 when we moved north to the district of Amsterdam, 50 miles north of Yorkton. We rented a farm four miles northwest of Amsterdam. Albert was already in Amsterdam, and I went up with my mother and the household goods in a coupe car. I sat on the open-air rubble seat at the back of the

\footnotetext{
${ }^{15}$ The relocation plan was initiated by the Saskatchewan Government, under Hon. J.G. Taggart, Minister of Agriculture. With the Prairie Farm Rehabilitation Act of 1934, the federal government subsequently took over the relocation. This included a "free freight" program to move the machinery and livestock. See also Marchildon (2009).

${ }^{16}$ A significant part of this migration was out of the drought-stricken areas of southern Saskatchewan to the Aspen Parkland further north (Laforge and McLeman, 2013).
} 
vehicle. The person in the Handsworth hardware store was very good to us, he took my mother and I in this coupe car (like a cab of a half-ton truck with rumble seat behind the front seat). My father moved the equipment, cattle and horses by train to Amsterdam. This was a long trip since the line had to first go to Regina then switch back toward Yorkton. The government program, called "free freight," allowed for two box cars, one for equipment and one for cattle and horses.

This trip with the livestock and machinery was one of the last serious jobs that my father did. After that he was too sick to be making the farming decisions, which were left to my mother, Albert and me. About the only thing my father could do was cut wood with a bucksaw. My mother would give him heck for doing things wrong; she was short tempered and did not understand his mental illness ${ }^{17}$. With little ability to speak English, my mother was lonely, missing her daughter who had provided a link to people who could not speak French.

We had a house that was poorly constructed with no insulation. The winter winds would come right in. We had to go three or four miles to get wood, and we needed a lot because the house was so cold.

My parents rented a half section in the year 1934-35. We had 6-8 horses and 10-15 cows. We planted a beautiful crop which had much promise, but we had hard luck once again. The crop completely rusted out. We thought there was still some grain in the crop, and we cut it into sheaves for harvest, but after threshing one load we realized that the cost of threshing was higher than the value of the wheat. We sold it for cattle feed instead.

When we were in the Amsterdam district, at age 15, my parents let me hop a train to visit a friend, Frank Rolufs, whose family had also left the Handsworth area and they now lived at Lady Lake, some 25 miles north of Amsterdam. I climbed onto a grain car of the train at Amsterdam and knew that I could jump off just near their farm when the train was going up a steep hill. This did not make me a hobo, but these were the times when there were a lot of hobos going across the country looking for work.

Leon often told the following "epic" story of his trip back to Handsworth: During the summer, I made the trip back to Handsworth by bicycle to help my brother-in-law Joe with the summerfallow. This is a distance of about 170 miles, with of course no pavement on the roads. We had bought a second-hand bike in exchange for some stove pipes and sealers that were not needed because we did not have a garden. On the first day, I made it past the reserve south of Yorkton, sleeping in a farmer's yard. I was lucky that they let me sleep in the bunk house that was used for threshers. The next morning, I will always remember the wife coming to me with a big platter of toast and eggs. I caught a ride with a farm truck for a few miles. The hardest part was climbing the Qu'Appelle Valley. On arriving to Whitewood, I chanced to find my cousin Emile Gatin, and put my bike on his load of oats, making my way to his home in Saint Hubert on the second night. This load of oats was relief grain that was distributed to farmers who had crop failures, so that they could feed their cattle. I spent a couple of days in Saint Hubert, going

\footnotetext{
${ }^{17}$ Leon spoke of his father's mental illness as possibly associated with the migraine headaches that would even bring his father to the point of vomiting. In later life, Félicien Beaujot must have suffered from a type of dementia. Joseph Driscoll, grandchild of Félicien and Bertheline, recalls that, at age 10 in the summer of 1944, he helped his Uncle Albert build their retirement home in Saint Hubert. At that time, Félicien's dementia was to the point that he had to be recovered when he would wander out of the house.
} 
to church on Sunday and playing ball in the afternoon. Then I went on to Handsworth, another full day's ride, about 50 miles. After a month of work, I made the return trip. On the return trip, my sister Flora had packed a large lunch basket, but as I looked back to wave goodbye, I had a wipe-out coming down the steep hill right behind their house, and the lunch scattered. I took a different route, visiting some friends from Handsworth who had moved to a farm between Broadview and Grenfell. The next day I pushed my bike up the other side of the Qu'Appelle, catching a ride for a few miles and managing to get home that night.

Besides the difficulties of farming during the drought conditions of the mid-1930s, we did not feel at home in this Ukrainian district. Mother, in particular, had never learned to communicate in English and now she did not have her daughter to help translate into French. My parents had much bad luck and serious health problems, yet they did not leave the farming industry, nor did they leave Saskatchewan, when many others were leaving.

\section{Back to Saint Hubert, 1935-44}

The family's return to Saint Hubert from Amsterdam was in the cold November of 1935. The parents travelled by truck with the smaller household goods and the cattle that had not been sold.

Leon gives the following account: Albert and I had each a rack pulled by two horses, carrying all of our machinery, furniture, hay for the trip, plus a total of 13 horses and colts. We had about 15 bags of potatoes in the middle of the two racks of hay. This was a six-day trip in the dead of winter. Each night we asked farmers if we could stay in the barn yard. One night the horses got loose and ate the hay from around the potatoes, freezing the potatoes. Another time, we had stopped in a farmyard, but the horses got loose onto the railroad tracks. We were very scared because there were many trains and all our horses could have been lost. Some people let us stay in the home, and at other times we slept in barns. That was an awful trip. There was one compensation: arriving at Whitewood, I got to have a beer at the pub even though I had just turned 16.

For the next four years, between the fall of 1935 and the fall of 1939, we rented various farms including the Lamont farm near Whitewood and the Yvon Bourhis farm west of Saint Hubert. We worked the farms with our 8 to 10 horses, and we milked about 10 cows. I worked out, and so did Albert. The dust bowl conditions came a little later in the St. Hubert area, but they were equally severe.

On return from the North, all members of my family had poor health. Father's mental illness was so bad that he could not make the farm decisions. This was very hard for my Mother who had lost a lung to the Spanish flu, and also had a poor heart. Flora and Albert had suffered from rheumatic fever.

As of 1936, Albert had worked on the construction of No. 9 highway south of Whitewood: "driving three horses on a dump wagon, earning $\$ 5.00$ a day, which in those days, we thought was big money" (Beaujot, Albert, 1980). Besides looking after the farm, Albert worked with Edmond Bachtold on the Joan of Arc Home. During this time, Albert worked as a carpenter with Maurice Gerard, then he worked with Cecil Westcott of Whitewood building plywood grain bins and eventually on his own renovating various homes. With a weak heart that would race if he worked too hard, carpentry suited him because 
he could do it at his own pace. Having suffered from rheumatic fever when he was young, Albert's heart would palpitate, and he would get exhausted if he worked too hard shoveling grain or manure.

Leon continues: In 1936 or 1937, when things were particularly difficult, I hired myself out to work for farmers. The farmer would pay $\$ 2.50$ per month and there was a government subsidy for another $\$ 5.00$ per month. One of my first jobs was harrowing, that is, pulling a set of harrows to level the ground after seeding, with six horses. There was a dangerous incident when one of the lines controlling the horses broke and the horses started going around in circles as I could hardly control them with the remaining line. I was in danger of becoming entangled in the equipment and so after a few desperate circles, I decided to let the horses go straight when they were lined up with a bush. Sure enough, they ploughed straight into the bush and the harrows stopped them dead in their tracks. However, when I reported the accident to the farmer, he did not appreciate my ingenuity and gave me hell instead.

In 1939 the family moved from the Lamont farm near Whitewood to the Yvon Bourhis farm, west of Saint Hubert, across the valley from the Mullie farm. We had a good crop and garden. I helped to build the MacKay Dam north of St. Hubert. I collected stones from the stone piles of farmers with two horses and a wagon and put the stones down on the inside of the dam to prevent wash-out.

I also did some work on the Mullie farm, such as hauling manure and helping with harvest. It was a lot of fun working there, and we would also play ball and go to dances together. Dorothy and I started going out together in 1938.

Once, my future brothers-in-law Raymond and Mike made some 'real wild' homemade beer. The only way to capture the beer was to have a milk pail at the ready, punch a nail hole in the bottle cap, letting it squirt into the pail. One bottle would half fill a milk pail. The foam was very good for you.

After I left for the army in 1941, my parents and Albert remained on the Bourhis farm until 1944 when they sold out and moved to the village of St. Hubert. Albert built a home for our parents, as a property of the Ste-Jeanne-d'Arc convent, in the village. ${ }^{18}$

\section{Wartime conscription: The army, 1941-1946}

The war came when Leon's family had already many difficulties and hard times. Leon felt that he was much needed to help his family at home, and he did not voluntarily enlist in the Canadian military. In May 1941 he was conscripted into the military and served in Canada. His conscription was under the terms of the National Resources Mobilization Act, 1940 (NRMA). Persons who had enlisted voluntarily have been called " $A$ " men because they were volunteering for "Active service" with the expectation that they could be called for overseas combat. Men conscripted under the terms of the NRMA have been called " $R$ " men because they were in "Reserve" for overseas deployment if necessary. These men, who were the only persons ever compelled to serve in the Canadian military, are also known as NRMA men (Byers, 2016). Until November 1944, conscripts could not be required to serve outside of the Western Hemisphere, unless they specifically volunteered for overseas service (Byers, 2016: 158).

\footnotetext{
18 This house, that Albert Beaujot built in 1944 was later purchased Paul and Josie Jordens. In 1975, their niece, Mona (née Decelle) and Gordon West bought the house and moved it to Langbank where they still live.
} 
With the 7 December 1941 attack on Pearl Harbor, and Japan entering the war, there was more need for persons serving in Canada. The plebiscite held on 27 April 1942, and Bill 80 passed in August 1942, allowed the government to send NRMA men to overseas service (Byers, 2016: 105-109). However, these provisions, allowing the government to send NRMA men overseas, were not used until the fall of 1944. Over the summer of 1944, there were increasing difficulties in providing overseas reinforcements. On 23 November 1944, Cabinet passed an Order-in-Council authorizing 16,000 conscripts to be sent overseas. A total of 9,667 NRMA recruits reached the front as conscripts, of which 2,463 saw duty in operational units (idem, p. 237). Altogether, the NRMA recruits numbered 158,056 , that is over $15 \%$ of the 1.1 million men and women who served during the war (idem, pp. 3, 233).

The details of Leon Beaujot's military service have been obtained by applying for his "Military Service Information" at the Personnel Records Division of Library and Archives Canada. These documents indicate that Leon was drafted for Basic Training at Regina on 20 May 1941. After the 42 days of basic training, he did 36 days of advanced heavy artillery training at Brandon, Manitoba, as of 25 July 1941. His "enrolment form" based on the National Resources Mobilization Act, 1940, is dated 23 August 1941 and signed by Leon Paul Rene Beaujot. The enrolment form indicates that Leon was 5 feet 5 inches, 146 pounds, brown eyes, dark brown hair, dark complexion, with the trade of "raising horses," and preference for army (infantry) or R.C.A.F. (Royal Canadian Air Force).

The five pages of "record of service" indicate that Leon was deployed at Mary Hill, Macaulay, Esquimalt and Prince Rupert (British Columbia) and Sussex (New Brunswick), over the period November 1941 to June 1945. He was also granted several leaves. The record of service includes the following: After his training, he had a leave from 16 August to 1 October 1941. He was then reposted at Mary Hill (BC) then at Macaulay (BC) and granted compassionate leave without pay for 19 May to 17 June 1942, then leave of absence without pay for 13 July to 31 October 1942. He was back at Mary Hill on 26 November 1942 and granted increase in pay of 20 cents per diem on 1 January $1943 .{ }^{19}$ In 1943 he got agricultural leaves of 47 days in the spring and two months in the fall. He was then posted at Esquimalt (BC) on 27 November 1943 and granted Xmas leave of five days with pay of 50 cents per day for 30 December 1943 to 3 January 1944. After the postings at Mary Hill, Macaulay and Esquimalt, near Victoria (see web site for CFB Esquimalt Navel and Military Museum), Leon was posted, as of 21 April 1944, at Prince Rupert (BC). He was granted seeding and harvest leaves for 2 June to 25 June and 1 August to 8 December 1944. On the return trip to Prince Rupert, heavy rains had washed out the train tracks, and Leon arrived only on 29 December 1944, being deducted six days of pay for the AWL offense. On 10 March 1945, Leon was transferred to Sussex NB, for advanced infantry training, after this training he was granted six months composite farm leave from 5 June to 4 December 1945. This was then extended to 4 March 1946.

Leon's Canadian Army Discharge Certificate is dated 29 January 1946 in Regina. The associated documents state that Leon was a "fully trained artillery man at rank of Gnr (Gunner) with a total service

\footnotetext{
${ }^{19}$ This $\$ 0.20$ increase in per diem was a $15 \%$ increase to $\$ 1.50$ per day [see General Order $1943\left(25^{\text {th }}\right.$ Feb 1943$)$ in Department of National Defence, 1944] . In 2020 Canadian Dollars, $\$ 1.50$ is equivalent to $\$ 22.24$ per diem or $\$ 8,120.00$ for a year.
} 
of 36 months in Canada" with future plans to "go back to own half section farm". In the section on preenlistment education, it states that he "completed Grade 8 at a Sask. Rural school in 1934 and his languages were "English and speaks French." In the section on "basis for recommendations, the form indicates:

This 26-year-old soldier is of medium height and wiry build. He is alert, frank and expresses himself well. He bought and operated a half-section farm while in the army and plans to return to this work. He has a totally agricultural background, owns some stock and equipment and should be successful on this farm. He wishes to obtain a loan from Veterans' Land Act, for the purchase of a tractor. He appears to be a good financial risk as he has been able to clear a half section of debt in the last four years.

The document on awards, dated 14 October 1949 indicates that Leon Beaujot, with Regimental No. L601111, had the rank of Private on discharge and received the following Campaign Medals: War Medal 1939-45.

At the time of his $90^{\text {th }}$ birthday in 2009, Leon recalled: When I was conscripted to the army, there was Basic Training in Regina then with Heavy Artillery in Shilo, Manitoba. They then put about 400 of us on a train to Vancouver. That was quite a trip. When leaving Brandon, we were told that if we lined up properly, we would each be able to buy a case of beer at our next stop in Moose Jaw, and the next stop would be Vancouver. It was hot on the train, but we found that we could keep the beer somewhat cooler by using our shoelaces to hang the beer bottles out the train windows. This was quite a sight to behold, with all the bottles hanging out on shoelaces on both sides of the train.

I had been trained for heavy artillery and was sent to Fort Macauley on Vancouver Island. I was there for about two years, with the huge guns that were meant to shoot at ships or airplanes. This heavy artillery needed some eight men to manipulate and project a 60-pound shell out of a 30 feet cannon barrel. We practiced destroying targets that we could only see through binoculars, some two to three miles offshore. Other times we stood on guard, ready to operate the artillery. There were always two people standing guard, and the rest of the platoon was below in the war shelter, playing cards, eating and passing the time. The cannons had a range of about two miles. Ear plugs had to be worn, yet I developed a hole in one ear, which caused problems for the rest of his life.

When Pearl Harbor happened, we were on steady duty in our boots for a week straight until relief arrived. It was a very tense time. We were on high alert and told that the Japanese could launch an attack at any time. We were to ensure that no Japanese military vessels would arrive over the ocean. Only one Japanese sub was ever spotted off the West coast and destroyed. ${ }^{20}$ For several months the

\footnotetext{
${ }^{20}$ On 20 June 1942, a Japanese submarine shelled a remote lighthouse on Vancouver Island, constituting the first and last Japanese attack on Canadian territory (Byers, 2016: 105).
} 
Japanese army occupied Kiska Island and we paid particularly close attention, all the way up the Pacific Coast. $^{21}$

After the 7 December 1941 attack on Pearl Harbor, we had the job of gathering the Japanese fishing boats into the Victoria Harbour and holding them there with warning shots until the fishermen were deported into camps in the interior for the remainder of the war. Holding back tears, Leon recalled in retrospect: This was terrible, they were Canadians just like us and they had done nothing wrong, they were just fishermen, but they lost everything. It was a terrible thing for the Japanese fishermen, and also for us who were commanded to treat them this way.

We were moved to various locations on Vancouver Island during a two-year period, then my unit was sent to Prince Rupert for about a year. That was quite an isolated location, and we had to go out on boats to man the guns on small islands, carrying our food for the day, and blankets to keep warm for the 24-hour guard.

I applied for spring and harvest leave several times, based on my family's poor health. We had to pay our own costs when on leave, so I typically travelled by bus as it was cheaper. On one return to Prince Rupert, heavy rains had washed out the train tracks, which was the only means of transportation. By the time I got back to Prince Rupert I was Absent Without Leave (AWL) and was punished by being held in a type of prison and forced to run for about a half hour for a few days.

The commanding officers, who were largely veterans from the World War I, were hard on those who had been drafted but who had not signed up for overseas service. We were called 'Zombies'. ${ }^{22}$ The persons of German ethnicity received particularly harsh treatment. I recall an incident when one of the officers had it in for a German soldier, using names like "Yellow" (coward) or "Zombie". At one point the soldier called up the officer on this and they had it out in a boxing match. The soldier won out with the loud support of his comrades.

Some people got dispensation due to medical reasons, but each time Leon was tested he received top marks on each of the seven criteria that were measured. This qualified him as P1111111. For instance, the Personnel Section Record dated 25 November 1942 indicates this top placement on the PULHEMS scale measuring Physique, Upper extremity, Lower extremity, Hearing and ears, Eyes and vision, Mental capacity and emotional Stability. On each criterion, " 1 " indicates top rating and " 8 " indicates "unfit for service."

\footnotetext{
${ }^{21}$ Japanese forces had occupied Kiska Island, Alaska, since June 1942, bringing further concerns along the Pacific coast. On 15 August 1943, American and Canadian forces landed on the Island but the Japanese had secretly abandoned their position two weeks earlier (Canadian War Museum, 2020).

${ }^{22}$ In his book on Canadian conscripts in World War II, Historian Daniel Byers (2016) uses the title: Zombie Army: The Canadian Army and Conscription in the Second World War.
} 
When I was first conscripted, I had wanted to join the air force, but was not allowed because I did not have Grade 10 education. They told me that if I signed up for overseas service in the army, they would ensure that I would get into the air force, but I did not trust them.

Then on 10 March 1945, I was sent to Sussex New Brunswick, with the expectation that I would be deployed in Asia. We underwent more training for regular (foot) infantry, such as crossing a river on a rope with a heavy backpack. The training included both physical fitness and exercises such as using maps to find one's way back to camp.

When in Sussex, New Brunswick, I applied for spring leave to sow the crops in the spring of 1945. At first my leave was denied, and it seemed that we were to be deployed. Then the war in Europe ended, I was granted spring leave, and I was never called back.

In the winter of 1945-46, Dorothy and I went by horse and sleigh to Inchkeith and the train to Regina so that I could pick up my discharge papers (dated 29 January 1946). We stayed for the night at the home of Ed and Isabella Ross, United Grain Growers elevator agent in Inchkeith, then paid \$6.35 each for the return trip to Regina, staying another night with Leon's cousin Ernest and Anita Gatin in Regina. The trip was not easy, being mid-winter and Dorothy six months pregnant, it was important to get these discharge papers, putting behind us the war and all it represented, so that we could really start anew.

The army food was particularly bad, giving me a lifetime dislike for rice in any form. We were fed "hardtack" cookies. Once we found worms in the cookies, so we got into the kitchen and dumped several boxes of these cookies into the ocean. A few times, we managed to break into the kitchen and have a feast of eggs and toast, during the night watch.

After the war, I had essentially no savings. The wages that we got were just $\$ 35$ per month, plus room and board, of course, and "monkey suit" clothing. I also had to pay for the expenses of travel for the home leaves.

While I had some fun times, managed to go across the country, made some friendships that have lasted a lifetime, and I was always proud to show others that I was getting letters from my love in Saskatchewan, these were really five lost years, in the prime of my life. It was particularly difficult knowing that my family needed my labour, and my fiancée was waiting for me. But then, that is war.

\section{Retirement of Félicien and Bertheline Beaujot in Saint Hubert, 1944-1955}

While Leon was in the army, his parents and his brother Albert continued to rent the Bourhis farm, across the valley from the Mullie farm. Besides looking after the farm, Albert worked on the No. 9 Highway then at the Joan of Arc Home. With Félicien's health deteriorating rapidly, Albert Beaujot and Edmond Bachtold built a house in the village that would accommodate a family who worked for the Home. In 1944, Albert and his parents sold their horses, cattle and machinery and moved into this house in Saint Hubert. 
While living in the village of St. Hubert, Félicien contacted pneumonia and became a patient at the Joan of Arc Home. The family was by his bedside for a week and he died on 8 January 1946, at the age of 67. He had a difficult life, coming to Canada in 1892 at age 13, losing his father in the same year and his mother when Félicien was 25. There was hard luck: a failed attempt to move to California, crop failures, health problems in the family, and much suffering of his own. He had suffered debilitating migraine headaches through his life, to the point of vomiting and almost fainting, eventually also affecting his mental health. But there were also good times, working for the counts, purchasing a farm of his own, and making arrangements to marry a young woman from France. He had a good sense of the oncoming weather, and an expert with horses.

At a time when many gave up on farming, Félicien remained a dedicated farmer seeking to make a living through very difficult circumstances ${ }^{23}$. When his illness prevented him from active participation in farm work, he continued to chop wood to keep the fires going. He was always very gentle and soft spoken, and he cared much for his wife and children. He was always mild and not one to argue, a friendly and helpful neighbour.

In October 1951, Albert was the first of his generation to make an extensive trip to visit with his mother's family (Sénéchaud) in France. In 1952, he built a home for himself and his mother, on the west side of the village of St. Hubert, close to the cemetery. He then worked full time for the Joan of Arc Home, as a handy man with Vic Beauregard and Frank Topinka (Beaujot, Albert, 1980: 60):

First we built a butcher shop, cooler and freezer and renovated the inside of St. Roch's, which was occupied with patients of all ages, a lot of them invalids. Also part of my work was chauffeur, driving a van for the Sisters to Whitewood, Wauchope, Forget, Montmartre, Weyburn and Prince Albert. I trucked freight from Whitewood. I also worked at building the east wing of the home. I hauled all the gravel for the cement work, from the Sand Plains, south of Percival.

Flora and Joe Driscoll continued to farm in the Handsworth district where their six children were born between 1933 and 1950. When Bertha was seven and Joe was six, they started school, walking two miles to Hazelbank, but the school burnt down that winter (Driscoll, 1992: 13). The following fall, Bertha went to the convent at Forget, with Joe going the following year. When Bertha was only eight years of age (1941), and by herself at the Forget convent, she contacted scarlet fever. Her parents came to visit but Bertha was quarantined and only allowed to wave to her parents from the window.

Flora continues (Driscoll, Flora, 1980: 96-97):

By 1943 they decided to hold school in an old log house, on the Andy Dayman place, where the children attended school until 1947. That year they built a new school on the corner of our land,

\footnotetext{
${ }^{23}$ At the 1891 census, the year before the Beaujot family came to Canada, there were 9,244 farm holdings in all of Alberta and Saskatchewan. In 1911, Saskatchewan had 95,013 farm holdings, which reached a peak of 142,391 in 1936 and had declined to 112,018 by 1951 (Statistics Canada, 1983: Series M12-22).
} 
S.E. quarter of 34-10-6. That was also the year we bought our old four room house for five hundred dollars ... which we moved with twelve horses a total of twenty miles and located it on the S.E. quarter of 33-10-6, moving into it in 1948. In 1949 we bought the adjoining three quarters of section 28-10-6 which gave us a total of $1 \frac{3 / 4}{4}$ quarter sections.

Bertha, Joe and Monica went to Montmartre convent to complete their high school. The sisters charged twenty dollars a month for the girls plus they helped with dishes and housekeeping to help pay for their board. As the Sisters did not board boys over ten years old, they offered Joe the hired man's job of milking cows, looking after stock, feeding chickens, cleaning barns, cutting grass and hedges, plus gardening, as well as keeping the coal bin full. He did this for his board and lived in a little shack in their yard. From then on they all took their grades nine, ten, eleven and twelve at Montmartre, so for eleven years they had a Driscoll boy for their chores: first Joe, then Jack and later, Leon.

Bernice, born in 1950, went to the local school, then to Handsworth and Stoughton. Bernice was the only one born in a hospital: the other five children were born at home. Over the time we managed to raise our herd of cattle. We bought our first tractor, an old John Deere in the fall of 1949 , that was the only one we ever had. ... The roads were not even graveled so we were usually snowed in from mid-November until spring. Neighbours took turns going to town for groceries in Handsworth by sleigh and horses fourteen miles away, which was the only time we also got our mail.

Bertheline died on 19 December 1955, at age 70. She had gone to the Regina hospital because of a bronchitis infection. The doctors found that she needed an operation on her uterus, and they decided to operate even though she had only one lung and had a weak heart. Leon Beaujot continues: Before we knew it, they phoned that she was dying as a result of the operation. Albert and I immediately decided that we would go to her bedside. I first had to make my way to St. Hubert so that we could drive from there to Regina. I went on horseback in the middle of the night. The snow was so deep that I had to walk the horse some of the way. I could walk on the hard snow but the horse would punch through, making it particularly difficult for the horse. When we arrived in Regina with the van from the St. Hubert home, mother had already died, and we came home with the body for the funeral in St. Hubert.

Mother died just after receiving her first pension (Old Age Security) payment, which in those days was at age 70. She had a difficult life, particularly the months of hospitalization with the Spanish Flu in California, where she was near death and lost a lung. She received no government assistance when her husband was disabled, nor when he died in 1946.

She had always worked hard, but would lose her breath because she had only one lung. If she pushed herself too hard she would have a shortage of breath and her heart would palpitate. She was good at growing vegetables in the garden, even strawberries, and at preserving them for winter. When travelling back to St. Hubert from north of Yorkton she observed a huge patch of rhubarb and asked the lady if she 
could have some. On arrival, she made jam with the rhubarb. She also knitted socks and gloves, and repaired clothes.

She got along with everyone but she had her own mind and did not hesitate to speak out. Bertheline had difficulties with her husband's illness as she increasingly had to shoulder responsibility for family decisions. Her husband's mental health problems could make her frustrated and upset. After Flora's marriage in 1931, Bertheline missed the company of her daughter, who had also served as a translator when interacting with anglophones. Her lack of ability in English, and lack of a telephone to contact her daughter, contributed to feelings of isolation. She is remembered as a deeply religious person, fairly strict with her children, but very caring for all, especially her grandchildren.

Leon Beaujot reflected at the time of his $90^{\text {th }}$ birthday: When I was small, I was with my father a lot as Flora and Albert were older. He would take me out to the fields. When I would come home I would be as black as him, full of dust. He always had sayings which expressed happy or funny thoughts. I remember him referring to the toilet as the place where the Pope would go without telling anyone ("Où le Pape va sans le dire").

He had learned to speak English when working for the counts. While he could speak English, he would swear in French, like "Au nom de jot" (not as sacrilegious as "au nom de Dieu"). I don't know where my Dad got his education, he had very little schooling, but he could write in French. He was left handed and he would get the ruler across his fingers by the teacher who was forcing him to write with his right hand. He became ambidextrous and he would change hands when working, for instance with a shovel or hay fork.

I never knew him very long when he was well. At Handsworth when I was seven he was only 49 which is pretty young to be getting old. I think of him now more than I used to. He faced more difficulties that I did. I am now 20 years retired and my father had no retirement. My parents had to give up one farm after another: in California due to illness, the Daley farm that they could not afford to buy, in Handsworth due to drought, and up North due to rust.

In Memories of St. Hubert 1980 (p. 60) Leon Beaujot concludes:

Félicien and Bertheline Beaujot faced many hardships and heart breaking experiences. When I think back, as I write I wonder how they ever managed with so little, and still gave us enough to be healthy and satisfied. We have a lot to be thankful for.

There were 5 grandchildren at the time of Félicien's death in 1945, and 12 at Bertheline's death in 1955, but there would eventually be 17 grandchildren, and 43 great-grandchildren ( 20 through Flora, 3 through Albert, 20 through Leon). Before continuing with Leon's story, the following chapter treats Dorothy Mullie and the Mullie family. 


\section{Chapter 5 \\ Dorothy Mullie and the family of Paul and Julienne (née Smets) Mullie}

Paul and Julienne Mullie, the parents of Dorothy Beaujot (née Mullie), arrived in Canada in 1911. After their marriage on 19 July 1910, they crossed the Atlantic on the SS Canada, leaving Liverpool on 4 March 1911 and arriving in Halifax on 12 March 1911.

Paul was the third of eight children of Louis and Félicie Mullie. These eight children were all born at Ploegsteert, Belgium, next to the border with France, where the family rented a farm ${ }^{1}$. Louis Mullie was also church warden (marguiller) at the church of Saint-Pierre and Saint-Paul, Administrator for the parish, and President of the Société de Secours Mutuels (mutual help society) of the Commune of Ploegsteert.

Ploegsteert was then in the Flemish province of West-Flanders. The family spoke Flemish at home and Flemish was the language of primary education, with further education being mixed (both Flemish and French) or only in French. Since the 1960s, Ploegsteert was transferred to the francophone province of Hainaut as the language majority had shifted to French.

In 1901-1905, Paul was at the Catholic University of Louvain ${ }^{2}$, where he earned the degree of Engineer in Agronomic Sciences. The address on his student $\operatorname{card}^{3}$ is shown as Ploegsteert. After completing his degree, the registration document at University of Louvain indicates the following as Paul Mullie's profession and residence after finishing university:

Chef de cultures à l'Ecole de Ruysselede (now Ruiselede, West Flanders, $60 \mathrm{~km}$ north-east of Ploegsteert), Régisseur (manager) de M. le Comte de Marnix à Overyssehe (now Overijse, Flemish Brabant, east of Brussels). Fermier à St-Hubert, White Wood, District de Saskatchewan au Canada.

Thus Paul would have had two jobs in agricultural management before leaving Belgium. At Ruiselede, he would have been managing the agricultural operations at the Ruiselede School. This was a reform school, founded in 1849, with the mission of providing education in agriculture to rehabilitate criminal (we would now say delinquent) youth during the economic crisis of 1840s in Flanders. The school is now called De Zande (The Sands in English), classified as a national heritage site of Flanders, located in in the municipalities of Ruiselede and Wingene ${ }^{4}$. At Overijse, Paul Mullie would have been Intendant,

\footnotetext{
${ }^{1}$ The address of this farm is now 9 Chemin de la Blanche, 7784 Comines-Warneton, $2.9 \mathrm{~km}$ from the centre of Ploegsteert (see Chapter 3).

2 The Catholic University of Louvain now operates in Flemish, but at that time the language was French.

3 Paul Mullie's student card also indicates the following: 1901 admission exam, 1904 Agricultural Engineering (Ingénieur Agricole) degree, 1905 Engineer in Agronomic Sciences (Ingénieur en Sciences Agronomiques).

${ }^{4}$ Ruiselede and Wingene are adjacent municipalities just south of Bruges in the province of West-Flanders. These municipalities are at the edge of a sandy stretch of land where subsistence agriculture was combined with domestic industries such as weaving and straw hat making. As the industrial revolution mechanized textile
} 
managing the agricultural lands of the Count of Marnix, and probably living in Overijse, in or near the castle. $^{5}$

It was at university that Paul met François Smets, who was in the same year of the Agronomic Sciences program, and whose sister, Julienne, he would eventually marry.

Julienne Smets was fourth of the six children of Jozef Nicolas and Maria Philomena Smets, living in Sint Truiden, Belgium, at 25 Hamelstraat (25 rue des Moutons). Jozef Nicolas had been a widower, with three children from his previous marriage to Jeanne Johanne Mommen. As described in Chapter 3 , he owned orchards and a grocery store.

Sint Truiden is in the Flemish speaking part of Belgium. However, at that time, while Flemish was the language of primary education, further education was either mixed (Flemish and French) or in French only. Julienne attended a Catholic boarding school for young girls, studying home economics and languages (French, English and German). After completing her education, Julienne worked at the family store which was also the family home (25 Hamelstraat, Sint Truiden). Julienne's brother François Smets had come to Canada in 1907, returning to Belgium in 1923.

The date of 19 July 1910 is well remembered in the Smets, Mullie and Dutois families. This was a double marriage with Julienne Smets marrying Paul Mullie and Josephine Smets marrying Jules Dutois. The wedding pictures were taken in the garden of the parental home ( 25 Hamelstraat, Sint Truiden). From the pictures we see a leather chair with brass nails. These chairs remain in the family and are at the apartment of Hugo Weets, Josephine's grandson. Their engagement rings were later passed on to Dorothy Beaujot and Josephine Weets. Julienne's ring is inscribed with "Paul à Julienne 24 avril 1910"; it was worn by Dorothy Beaujot and is now with her daughter Doreen Gardner. Josephine's ring is inscribed with "Jules à Josephine avril 1910;" it was passed on to Malou Weets and it is now with her daughter Ria Weets. This April engagement date is remembered as a time when the orchards of Sint Truiden were in full blossom, especially the cherry and apple trees.

In the marriage registration, Paul Mullie's profession is indicated as "régisseur (manager), living at Wyngene (now Wingene, West Flanders) where part of the Ruiselede reform school is located. ${ }^{6}$ The witnesses were: (1) Raymond Mullie, brother of the groom, farmer, living at Wytschaete (now Wijtschate), and (2) Antoine Smets, brother of the bride, employee, living at St. Truiden.

production, there was serious social upheaval and unemployment in this area in the 1840s (Lesthaeghe, 2016). This explains the placement of a reform school in the area and calling it De Zande (The Sands).

${ }^{5}$ The family of the Count de Marnix de Sainte Aldegonde is from very old nobility. A famous Marnix van St. Aldegonde was the last protestant mayor of Antwerp, before the Spanish reconquered the city from the Calvinists in the 1590s. They had several castles in Belgium and France. One of them was situated in Overijse, Flemish Brabant, East of Brussels.

${ }^{6}$ Part of École de Ruiselede, the reform school in agricultural education where Paul Mullie worked, was located in the adjoining municipality of Wingene, $10 \mathrm{~km}$ from Ruiselede and $50 \mathrm{~km}$ from Ploegsteert. 
Paul and Julienne would have lived for about eight months in Wingene before leaving for Canada. Their trans-Atlantic crossing was on the SS Canada (White Star / Dominion Line), leaving Liverpool on 4 March 1911 and arriving in Halifax on 12 March 1911, ten weeks before their first child was born on 2 June 1911. The manifest indicates that there were 969 adults and 117 children under 14 . On the passenger list, the names are shown as Paul and Marie Mullie, born in Belgium, with the intention to permanently settle in Canada, and able to read and write, destination of Whitewood. ${ }^{7}$ Paul's occupation in the country of origin is indicated as Civil Engineer and his occupation in Canada is stated as "farm." They were carrying $\$ 600.00$ (valued at $\$ 13,000$ in 2018), and stamped "Continental Bonus Allowed". This Continental Bonus subsidized the passage of farmers and agricultural workers who were immigrating to Canada. The amount of the bonus was $\$ 6.00$, representing about a quarter of the $\$ 25.00$ cost of the trans-Atlantic trip on third class. The SS Canada was launched in Belfast in 1896. It was used to transport troops in the Boer War (1899-1902) and once again for troops being transported to England from August 1914 to the end of the Great War. Its last voyage was in 1926 before being scrapped in Italy.

Julienne's brother François (Frank) Smets had preceded them in coming to Canada. After completing the same degree as Paul in Agronomic Sciences in 1905 at the University of Louvain, François first came to Souris Manitoba in 1907 then to Saint Hubert, Saskatchewan, on 5 April 1908. He farmed S.E. and N.E. of 34-14-3-2 then N.E. of 12-15-3-2. After Paul's arrival in 1911, they farmed together, until Paul and Julienne bought their own farm in 1912. François spent the winter of 1920-21 in Belgium then made a final return to Belgium in July 1923. Dorothy had two memories of her Uncle Frank, one was of his carrying her on his shoulders, and the other was of seeing him dismount his horse as he arrived at the gate at the bottom of the hill on the Mullie farm.

$* * * *$

Paul's brother Julien came to Canada in 1913; at first he worked with his brother, but Julien later established a homestead (NW 2-48-12) at Arborfield, Saskatchewan, at the northern edge of the grain belt, some $390 \mathrm{~km}$ north of St. Hubert. According to the homestead document, Julien applied for the homestead in 1913, received the property in 1914 and obtained the title in $1917^{8}$. The town of Arborfield developed adjacent to his property.

The records at the Ellis Island web site indicate that Julien Mullie, aged 30, left from Antwerp on the SS Lapland, arriving at Ellis Island, New York, on 2 April 1913. The source indicates that he was from Ploegsteert, Belgium, and on his way to his brother Paul's place in St. Hubert, near Whitewood, Sask. The attestation from the ship's physician says that Julien was not a polygamist, not an anarchist, that he is single, that his health condition is good, that he is not deformed or crippled, that he is 6 feet tall, of fair complexion, with brown hair and blue eyes.

\footnotetext{
7 See "Paul Mullie" under immigration/passenger lists at www.familysearch.com.

${ }^{8}$ See Department of the Interior 1913, document \#2937507.
} 
When he arrived in Eldersley in the spring of 1914, there was no transportation to his homestead at Arborfield, so he "purchased a wheelbarrow for $\$ 4.75$, put his trunk in it and started to push it the 37 km to Arborfield". The town book on Zenon Park further says: "When he came to a mud hole, he carried the trunk across on his back, then the wheelbarrow and then simply pushed on." In the French section of the account, it further says: "Les gens de Zénon Parc se rappellent encore de l'avoir vu passer" (Zenon Park History Book Committee, 1983: 8, 289).

Julien wanted a more isolated place to establish his homestead, to avoid conscription into the Belgian army during the war of 1914-1918. "They can come and get me" he had said. Paul and Julien were very different, with Paul very meticulous and Julien impulsive. A story is remembered when they were to go out together to use a chemical in the orchard. While Paul was reading the directions, Julien had woken early and did all the work before profiting from his brother's instructions. On another occasion, Julien had risen early to graft some apple trees before Paul, who was an expert in agriculture, could explain the proper procedure.

\section{Reflections on the migration experiences}

Little is remembered of these migration experiences. Why did they come to St. Hubert, what made them leave Europe, how did their experiences correspond to their expectations, why did they stay in Canada. There were family connections with people who had come earlier. The wars affecting Belgium must have had some influence, especially for men who were subject to conscription. It was often said that "ce n'était pas comme on nous l'avait dit" (it was not as we had been told to expect). When Julienne first saw the big blocks of ice that were used for refrigeration in Saskatchewan, she could not believe that people could withstand a climate that produced such thickness of ice.

In the case of the Beaujot family, there were hardships in Belgium that brought their departure. They had very little to take with them, and they first worked for the church, where François had a fatal accident in the year of their arrival, and where Justine cooked for the priest (see Chapter 3 ).

Félicien Beaujot would have been able to stay in Belgium when he returned in 1903, but instead he brought Joséphine and Adolphe Gatin, his sister's family, back to Canada. Similarly, the return of Frank Smets in 1923, and Julien Mullie's return to marry Marie Louise, indicate that Paul and Julienne could also have returned.

Originally, Paul and Julienne did not intend to stay long in Canada. The plan was to make money and return where Paul could have continued his career at university or agricultural management. But the Great War much affected the lives of the Mullie family in Belgium. Their farm being was essentially on the trenches of the battlefield (see Chapter 3). Paul Mullie often said that his brothers who had stayed in Belgium or moved to France had done better than he. With his degree in Agronomy, Paul was well set for a career in Belgium, having talents both as a teacher and as an agriculturalist. There were certainly disappointments in Canada, but life was also difficult in Belgium and France. A major impetus was probably the availability of land to purchase and develop in Saskatchewan. 
While their migration was not originally considered definitive, or at least they gave themselves the option of returning, the trans-Atlantic passage became a defining moment in their lives and that of their families. Correspondence was maintained with family in Belgium and France, and letters were highly prized, but the close relationships were clearly altered.

After the legal status of Canadian citizenship was established in 1947, neither Paul nor Julienne ever took Canadian citizenship, thinking that there was no need. Julien and Marie Louise did get Canadian passports for their 1953 trip to visit family in Belgium and France.

\section{Establishing the farm}

In March 1912, after a year of farming together with Frank Smets, Paul and Julienne bought their own farm four miles south west of St. Hubert. This farm consisted of 80 acres with house and yard (West half of SE quarter of 30-14-3 West of $2^{\text {nd }}$ ) and an adjacent quarter on the west side of the yard (SW of 30-143 , known as Nemeno). They would soon purchase NE of 19-14-3, the quarter across the road to the south of the home quarter, and NE of 24-14-4 a half mile west of the home yard (Cascaden).

This 560 acre $^{9}$ farm was well situated with a yard close to the valley, well water available in the yard, relatively flat fields with good drainage, and pastureland in the valleys, with beaver dams and springs making water available in the creeks. These creeks, which are tributaries to the Pipestone Creek, provide this area with a mesh of available water supply and spring drainage, every mile or two. At the same time, it was rather distant from rail lines, with the nearest grain elevators at Inchkeith, 10 miles to the South, and the nearest town for supplies was Whitewood, 17 miles to the northeast. It is said that the rail lines were set closer to the English settlements and far from the French settlements. This was clearly the case for St. Hubert, which was far from the rail lines at Inchkeith and Whitewood.

The house was extended in 1920, and in 1936 a dam was built to collect water on the edge of the farm yard for watering animals and for irrigating an orchard that was developed in the valley below ${ }^{10}$. While the orchard was quite a novelty for this area of the prairies, Dorothy remembers it as "a lot of work for what it was worth". Paul would bring apples to sell after church, but few people bought, and few came to pick-your-own. The work was extensive because Paul would dig a hole large enough for a coffin each time a raspberry was planted. Dorothy feels that she has the last laugh because the evergreen trees that she planted with her father, directly in the soil in a bush in the valley west of the farmyard, have survived and reproduced eighty years later, without the benefit of her father's extensive fussing. An offspring of one of these trees was planted in the yard of the house where they retired in Kipling.

\footnotetext{
${ }^{9} \mathrm{~A}$ farm of 560 acres (or 3.5 quarters) compares to an average of 295.7 acres for Saskatchewan farm holdings in 1911 and 473.0 in 1946 (Statistics Canada, 1983: Series M12-22; see also Fowke, 1957: 72).

${ }^{10}$ Edward Mullie, who now farms this land, has documents indicating the plans (dated 26 Sept 1936) and a license for irrigation (dated 16 January 1940).
} 
Having a Master's degree in Agriculture, Paul was on the forefront of agricultural development in southeastern Saskatchewan. He grew registered wheat and oats, gaining the title of "elite registered seed grower" and receiving trophies recognizing the quality of his work as a registered seed grower (see Box 5.1). He employed young people to collect the weeds from fields, and would even stop on the way to church to take out the sow thistles when this weed first arrived in the district. He also raised cattle and horses, testing the milk for its cream content to decide which Holstein cows to maintain and breed. He experimented with fruit trees, being an expert at grafting, and he developed a system for irrigation of an orchard that was planted in the valley below the dam. This orchard included apples, crabapples, plums, raspberries, currants and gooseberries. He even received prizes for grapes, which was very unusual for Saskatchewan. While it is no longer maintained, parts of this orchard still stand, 80 years later.

The farm had about ten horses, typically bought at auction sales, though later Mike and Raymond raised colts. Their life expectancy was about 18 years, and each horse had its own temperament. In the late 1930 s and early 1940s, the following machinery was used:

1. Plough: Two-bottom ( 2 times 16 inches) with 5 horses

2. Drill for seeding: 10 feet, with 4 horses

3. Harrows: 21 feet, with 4 horses, operator walked behind then later a cart added for seating

4. Cultivator: 8 feet with 4 horses or 10 feet with 6 horses

5. Binder with mechanical knotter: 8 feet knife, with 4 horses

The harvesting was done with a threshing machine that rotated among neighbours. The sheaves were collected by four teams, each with a man and rack, pulled by two horses. A 28 inch cylinder allowed for two sheaves to be thrown in at a time. There would also be an operator and someone handling the grain as it came into the granary. If the threshing machine was not available, the sheaves would be gathered in a stack for later threshing.

For cleaning the grain, Raymond constructed a Clipper seed cleaner consisting of a blower and 3 or 4 screens that would vibrate to separate the seeds from the weeds. The blower removed the chaff, light seeds and weeds, while the seeds and weeds of various sizes fell through the screens to trays below. Raymond's son John remembers operating this machine in the 1950s.

Until his own children were available, Paul would often have hired help on the farm. For some years, there were Hungarians who had immigrated as farm workers. At the 1916 Census, besides Paul and Julienne, then aged 35 and 38, there were Marie Louise, Jean and Raymond (aged 5 to 1 year), and three men of Paul's age: Mike Dowbenka and Maxim Zack listed as servants from Austria and Thomas Blackwood listed as lodger from Scotland. 
Box 5.1 Trophies - Paul Mullie

A large copper medal reads "Robertson Associate Token of Merit" with the inscription "P.A. Mullie $1950 "$.

Attached to the center of the medal is a colourful blue lapel pin that reads, "Canadian Seed Growers Association" around the outside, and inside the circle it reads "Heredity Purity Utility". There is also a lapel pin that is exactly the same as the center piece of the medal.

The two items were in a small jewelry type box, with the lid reading: "P.A. Mullie has fulfilled with conspicuous fidelity and success his obligations as a member of this Association, in recognition of which he has been presented with this token and admitted to the status of Robertson Associate Membership of the Canadian Seed Growers' Association."

Source: Now in the possession of Paul's grandson, Pat Beaujot.

\section{Establishing the home}

While Flemish was the first language of both Paul and Julienne, their higher education had been in French and they spoke French in the family. However, as she counted to higher numbers, Julienne would switch to Flemish.

Julienne was a very educated person, in comparison to others both in Canada and in Belgium. It is remembered that when she walked to church in 1911, from the home of her brother Frank, the neighbours remarked on the quality of her dress. She would be well dressed to go to the grocery store. She would talk with the men. She mixed well with people who did not speak French. She and Mrs. Jordens (Jessie, war bride, married Arthur) were the best of friends, often laughing their heads off after church.

Julienne also made sure that there would be a bathroom in the house. When the house was extended in 1920 , she insisted that there be an interior bathroom with a bath tub. It was very unusual to have a bath tub in a separate room, to the point that people questioned and ridiculed the family on this decision. People would say: "Oh, Madame, elle a besoin d'une baignoire". When another neighbour, Eva Gerard (née Praud) extended their house, Julienne asked the neighbour why she did not include a bath tub, and Eva replied: "No! People would make fun of me". On another occasion, a neighbour boy took advantage of a visit to the Mullie family to have a bath because he had never previously seen a bath tub. Dorothy even offered him some clean clothes but he said that he only wanted a bath. When the boy's mother found out that he had had a bath at the Mullie home, he was scolded. It is not that others did not have baths, but this largely occurred in a tub in the middle of the house, certainly close to the stove in winter. In all cases, including at the Mullie dwelling, baths occurred in the same water, with more hot water being added as each person had their bath, starting with the youngest who needed less water. 
After it had been extended to more than double its previous size, with four bedrooms upstairs, the Mullie home was a very convenient dwelling. There were two stairways, allowing a separate entrance for the hired help who also slept upstairs. Later this stairway was removed, extending the size of the new kitchen, while the kitchen in the old part of the house become an ice house for refrigeration.

By the tenth anniversary of their marriage, 19 July 1920, Julienne and Paul had had their five children, with Julienne now aged 42 Paul 39. All the children were born at home. Julienne employed a helper, such as Mrs Joe Bellehumeur (née Marie Adele Fleury, see Memories of St. Hubert 1980: 62), to provide assistance when the children were born, but she did not have hired help at other times. When Dorothée was born on 19 July 1917, she had an older sister Mary Louise aged six and two older brothers in Jean and Raymond aged four and two. Three years later, her younger brother Michel was born.

Having received his homestead in 1914, Paul's brother Julien Mullie proceeded to clear the land. In an interview with his nephew Jean Mullie who was visiting from France in 1967, Julien explains that the homestead contract required that ten acres be cleared: One had first to bring the land to life before the land could bring us life ("Il fallait faire vivre la terre avant que la terre nous fasse vivre"). He further says that it took $\$ 10.00$ and 11 days of work to build his first house, and that he would walk to church at Zenon Park, a distance of 6 miles. After having worked on his own for 10 years, Julien went back to Belgium to marry Marie Louise Duthoit on 11 February 2014 (see Chapter 3). They were passengers on the SS Melita, leaving Antwerp on 28 February 2014 and arriving at St. John, New Brunswick.

From the interview in 1967, we see that Julien had a half section until 1939 when he obtained a second homestead and eventually would have 13 quarters when the children had finished school and were working with him. ${ }^{11}$ In 1939 he worked the farm with six to eight horses. When he had a tractor, he left it to his children to operate, purchasing a combine in 1945. Being the eldest, Jeanne was first to finish school and she started to operate the tractor when she was 15 or 16, in about 1937. Her stepfather ensured that the Oliver 70 tractor ( 30 horse power) had rubber wheels and a comfortable seat.

Marie Louise interjects in the interview to say that, before the combine, harvest time was hard for the women with a house full of workers who had to be fed. In another interview recorded in 1980, Marie Louise talks about the isolation of farm wives on the prairies. In particular, she would repeatedly ask a Mr. Fournier to bring his wife when he came to the village: "When Mr. Fournier went to the village, we always said to him, 'Bring Mrs. Fournier with you when you go to town and then pick her up when you go home.' But he never did" (cited in Jutras, 1995: 45).

${ }^{11}$ The 1953-54 permit book shows 8.5 quarters owned and 2.0 rented for a total of 1680 acres. 


\section{Community}

Besides the regular socializing after church, other community events included the annual picnic, Sunday afternoon ball games, a fall supper, Christmas concert, card parties and bingo. The women had quilting bees to make a quilt to be raffled at the fall supper ${ }^{12}$. People would join in from neighboring communities, filling the hall below the church. While the priests did not allow dances in the basement of the church, this basement was later used for projecting silent movies, then talking movies, which brought the community together on Sunday nights, into the later 1950 s.

The dam at the Mullie farm was another winter gathering place for young people in the community. Paul Jordens would pick up some 10 to 15 people in the sleigh after lunch and they would return home in time for chores and supper on Sunday. The girls would skate and the boys would play hockey. The first year that the dam had been built, it filled with water in March and froze enough for Raymond, Michael and Dorothy to skate close to the edge. This was much fun as the ice was heaving below them as they circled around the edge of the dam. They did not realize the danger of the situation, with the steep embankments and deep water below them. They never told their parents, nor did they do this again, after they appreciated the danger. Michel in particular should have known better since he had done most of the work in building the dam.

Religion was an important base of community activities. Except when the roads were dangerous, mass on Sundays was a must. During the winter, most families needed to travel by horses to go to church. The men would drop the women and children off at the church, and then bring the horses to the community barn, with the return journey taking the same pattern.

Socializing at the steps of the church was an occasion to keep up with events in families and communities. There were always exchanges of views on the weather, a central element of conversation for farmers. Community was formed by finding common words and sentiments to describe the weather.

Corpus Christi Sunday was an important community event. Saint Hubert was known as a community that went all out for this celebration, which occurs in May or June. Everyone had something to do. The men worked first, to decorate three stops along the procession route. Tree branches around a garage door and a table in front provided the aura of a country grotto and altar. The job of the women was to prepare for a picnic that would follow, with little sandwiches and goodies. The boys got to carry the numerous candles during the procession, making sure that they would not go out in the Saskatchewan winds. The girls had the best job of all, to carry decorated baskets with flower petals that they would spread before the path of the priest and the congregation in procession. This was an all-day event. First there was the usual Sunday mass, and then we came back to church in the early afternoon for the

\footnotetext{
12 Once Dorothy and her brother Michael had been charged with bringing the cake to the Fall Supper, and they decided to wrap it in a blanket made with horse hide, only to find that by arrival the cake was not only squashed but full of hair. Mrs. Raiwet said it looked like someone had sat on the cake.
} 
procession, followed by a picnic. The procession lasted a very long time, but no one seemed to get bored because there was no TV or other distractions.

Religion affected community activities. Dances could not occur at the Saint Hubert Church because the priests objected, and they largely did not occur at Golden Plain school because of the fundamentalism of many of the members of the School Board. At Golden Plain, crokinole tournaments were a favourite community activity.

Young people went to community dances at Baines and Meadowlee schools. People would sell wine or moonshine at dances, for 50 cents. The selling of liquor was illegal "but the RCMP were 40 miles away," says Leon. Men would share a bottle, and they knew who had taken too much because they got sick. Meadowlee was known as a 4-40 dance because for every 4 on the dance floor, there were 40 outside. There would sometimes be fights at dances between French and Swedish. For some, alcohol made them aggressive, but nobody was seriously hurt. When sober, they were good friends once again. Leon recalls when he had gone to a dance north of Whitewood with two friends. One of them danced with the girlfriend of someone from a different ethnic group, and the friends were chased out of there, lucky not to get hurt.

Picnics and baseball games provided other occasions to socialize. From 1935 to 1940, Leon was active in baseball, which was a community event on Sunday afternoons. This included Dorothy's brothers Raymond and Michael, with the girls of the community watching and cheering for the Saint Hubert team.

Paul and Julienne would borrow a still from Eugène Beaujot to make their own homebrew. When this became illegal, Paul hid some of this precious product in the shelterbelt around the house. As the dust blew in from the fields, especially in the 1930s, one of these bottles was buried in the trees. Many years later, Raymond found a gallon of homebrew in the shelterbelt. Knowing that it was the real thing, and that his father would have divided things equally among his children, Mike demanded his share! His brother made the counter claim that the mineral rights were his when he bought the property, but he nonetheless gave Mike a "mickey" of the powerful brew. Just a lick of the spoon was still producing quite a buzz at the $60^{\text {th }}$ wedding anniversary of Mike and Jeanne Mullie.

\section{Transportation}

As of the mid-1920s, some people had cars but horse and wagon or sleigh remained the most common means of transportation and the only means during winter. Even in the 1940s, the general store in Saint Hubert organized neighbours to transport goods from Whitewood through a convoy of horses and box sleighs.

During the winter, the trip to and from Whitewood or Kipling, 17 or 13 miles respectively, was a full day's job, and was typically done only about once per month. Often a neighbour would come along or send a grocery list. The horses were put in a livery barn while shopping, so that they would be fed and 
rested, at a cost of $\$ 2.00$. The roads could become very difficult, even for horse and sleigh. With the trees along the roadway, the snow would gather, and become trampled and built up, sometimes to a height of four feet. It was essential to stay on the roadway, and not to stray on the soft snow off the trampled path. Dorothy says there was more snow in those days, and Leon agrees that more snow gathered in the roadways because of the trees along the roads. In the spring, one had to decide between a sleigh, which was better as long as there was snow, or a wagon whose wheels would get very clogged with mud.

Dorothy remembers the story of her mother and a neighbour having gone to Whitewood with horse and wagon to purchase two barrels of gas. The barrels had not been properly secured and they rolled off the wagon on the return trip. Being ingenious at solving such problems, Julienne and the neighbour backed the horses and wagon into the ditch, then rolled the barrels from the road and back onto the wagon. They were laughing so hard that they could hardly lift the barrels, but they managed to both control the horses and to retrieve the gasoline without incident.

Around 1925 an Overland was purchased as the family's first car. In 1928 there were poor crops and it was the last year that the family ran their car. In the 1930s the family could not afford to pay for the license on the car. A Model A was purchased in about 1935 and the family drove to Arborfield after harvest in 1937. This 300-mile trip was done at some 30 miles per hour, on roads that were very rough (referred to as "washboard"). There were six in the car, with suitcases strapped to the running boards. Paul was a poor driver and he let his sons drive. It was at Arborfield that Paul's brother Julien had settled, in 1913. When Julien was in his first car with Paul in Arborfield, he jumped out to greet a neighbour with the car still moving, forgetting that cars cannot be treated as horses, especially when your brother is aboard. Their wives had a saying among themselves that if one took half of each brother one would have a perfect husband.

Dorothy recalls her experience in getting a driver's license. She had driven on her own to Whitewood. The officer asked her how long she had been driving and how much she had driven. Not knowing how to answer, the agent answered for her: "you drove here didn't you, then ok".

After 1945, more and more people had cars, but these could not be used in winter when the roads were impassible. Going to church in winter was mostly by horse and sleigh. In cold weather, even when the roads were passable, cars and other vehicles were very hard to start. The battery would be too weak in the cold, and the crank had to be used to start the vehicle. To allow the crank shaft to be turned, kettles of boiling water would be poured over the engine block, or embers from the stove would be placed underneath.

\section{Education}

Dorothy's schooling started at the Jeanne d'Arc convent in Saint Hubert in September 1921. The nuns required that the children stay in residence, as a means of raising income for the convent. Dorothy continues: I started at age five and did Grades 1 and 2 there, with my older sister and brothers at the 
same school, but the boys and girls were kept completely separate, for classes, eating, and even for recreation. I sometimes saw my brothers through the fence, but I was not allowed to talk to them until we left for the weekend. There were no more than 30 children. We had mass every day in the chapel, with much kneeling, and slouching was strictly forbidden. The meals were poor, and I can still remember the taste of the sugarless porridge. The sisters were not trained to be teachers, and in effect neither did they want to be there, having mostly been placed in the convent by their parents. I remember my mother telling the nuns that teachers should be teaching, not sitting and crocheting as the children were left to learn on their own.

The sisters told us that we had to drink six glasses of water per day, but I had understood that I was to drink six glasses at one sitting. My mother found me crying because I was afraid to have a drink. Asking why I was crying, I explained that the sisters wanted me to drink six glasses of water and I could not drink that much. It took some convincing for my mother to explain that the six glasses were not to be drunk at one time.

When I entered Grade 3, the four of us went instead to Golden Plain School. This was a one-room public school where all schooling was in English. We were amazed to see the teacher help the Grade 1 students to read, having experienced none of this at the Saint Hubert convent. ${ }^{13}$

The Mullie family was rather important to maintaining this school which had been formed in 1896 as Golden Plain Protestant School District \#70. Dorothy probably started at Golden Plain in 1923, when the teachers were Miss Georgina Reid and Miss Gladys Wetherald. The following year Miss Isabel Little was the teacher, with Miss Penfold being the teacher in 1925 and 1926 (Langbank Memories, pp. 204-205). Dorothy continues: when I was in Grade 3, there were nine children at the school (4 Mullie, 2 Tait, 2 Wilton, 1 Dumonceaux). By 1928, the numbers had risen to eleven with the addition of a fifth Mullie. ${ }^{14}$ Mike remembers that there was one year when he was starting school and there were five Mullie children at the school. Jean, the oldest Mullie boy, would ride in ahead to start the fire at the school, for which he was paid, and the other four came with a team of horses. When Dorothy was in Grade 10, there were two remaining Mullie and eleven others for a total of 13 pupils.

In 1923-24, when they were first at Golden Plain, Marie Louise would have been in Grade 8, Jean in Grade 6, Raymond in Grade 4 and Dorothy in Grade 3, with Mike starting in 1926-27. They each completed Grade 10: Marie Louise would have finished in 1926, Jean in 1928, Raymond in 1930, Dorothy in 1931 and Mike in 1936. Raymond also did a short program in Agriculture at Indian Head. Being in the depth of the depression, these were not good years to be graduating into the labour force.

\footnotetext{
13 Dorothy's mother Julienne Mullie explains in a letter written, late in 1925, to her sister-in-law Marie-Louise Mullie, that the Mother Superior did not accept half-boarders at the Jeanne d'Arc convent. Also, the teacher at the Saint Hubert public school could not take the Mullie children because it made too many grades to teach.

${ }^{14}$ The picture on p. 204 of Langbank Memories shows Michel probably in grade one, plus Dorothy, Raymond and eight other children for a total of eleven.
} 
At Golden Plain, there were never enough students to make a proper ball team. For the school concert at Christmas, they joined up with the Sunnymead School, which was the next closest school at seven miles distance. There were also dances and picnics at school.

Dorothy continues: Lorraine Gary taught from the time she was 18; since she was from the district, we called her Lorraine, and we had to practice calling her Miss Gray when the inspector was coming. Except for a couple of months where there was a child of my age visiting in one of the local families, I was always alone in my grade. Raymond had one other in his grade, but when he was in Grade 10, his classmate was moved to another school because the family did not like the young teacher, thinking that she was incompetent. The Golden Plain teacher worked with Raymond to prove that she was a good teacher, and he passed the exams in Kennedy with flying colours while many of the other students failed the exams.

In Grades 8, 9 and 10, the exams were in Kennedy. As of Grade 9, the schooling was by correspondence. The children were at the school, but they largely worked on their own, completing 20 lessons per subject which were sent to Regina by the teacher. Dorothy continues, in Grade 9 there was a choice between Art and French. The teacher felt that I was good at Art and recommended that I opt for this subject, but I choose French. She did not know that I could read French and was astounded to see me read a whole page to the other students once the French textbook arrived.

It was a four mile trip to school, which the children did on their own, with a wagon in summer and a sleigh in winter, putting the horses in the barn on the school yard, and feeding them hay at lunch time. There were five gates to open and close on the way to school. In the winter, it was hard getting out from under the blanket in the sleigh to open and close the gates. Sometimes we would leave the gate open while the next sleigh made it through, but we once got hell because some horses in the pasture managed to escape between the two sleighs. When my brother Jean was 14 and 15, he had the job of starting the fire at the school, so he rode in ahead on horseback to start the fire.

Dorothy relates the following story which was taken out of the 'story page' of the Western Producer at the time. A young teacher arrived at her first school, hung up her coat and noticed that the students were huddled around the fire talking, so she joined them. They were talking about the tricks they would play on their new teacher who was to arrive at any moment. When she later went to the front to ring the bell, she sure got some surprised expressions on the faces of her students.

The Mullie children all finished Grade 10 at Golden Plain School. It was required to complete Grade 8. Grade 10 was higher than the average levels of schooling completed by Canadian children in the 1930s, but it was much less than the schooling that their parents completed in Belgium, which had included post-secondary education. The education of the children of Paul and Julienne Mullie was affected by 
the depression and dust bowl conditions of the 1930s, and the lack of an accessible high school. They would have had to go to boarding schools when their labour was needed on the farm. ${ }^{15}$

\section{Work at home and on the farm}

Through a series of letters, written in 1924 and 1925 by the Mullie children to the Mullie family in Arborfield, we get an interesting picture of farm family life (see Appendix 5.1 at the end of Chapter 5 for text of these letters). In February 1925, when the second of these four letters were written, Marie Louise was 13, Jean 11, Raymond 9, Dorothy 7, Michel 4; cousin Jeanne was almost 3 and Alfred was two months. Appendix 5.1 at the end of Chapter 5 carries 11 letters written at four dates (10 by the children and one by their mother).

As Annette Gunn (daughter of Michel Mullie) uncovered these letters among things that had been passed down from her grandparents, Julien and Marie-Louise Mullie, we were surprised that some of them were typed. Typewriters must have been rare in Canadian households of the mid-1920s. It is obvious that writing these letters served an educational purpose, especially in writing in French now that the children were taking their schooling in English.

These letters show that work on the farm and at home was "all hands on-deck," and there was considerable pride in family-farm production. In hers of 4 October 1924, Marie Louise says that during harvest she is the housekeeper (ménagère). It has to be that way, she says, because there is a shortage of labour: Maman is helping with the belts and pitch (pine pitch would have been used as belt dressing to stop slippage in driving the threshing machine), Jean is looking after the tractor and the threshing machine, while Papa is feeding the sheaves into the threshing machine. Since it was such a late harvest, the sheaves of grain would have been collected in advance from the fields. In hers of August 1925, Julienne remarks that they began cutting the Ruby wheat ${ }^{16}$ on 12 August 1925, getting a head start on harvest which had been delayed into October the previous year.

In his letter of 4 October 1924, Raymond says that before the rain came yesterday, they managed to harvest 5 acres of flax which produced 138 bushels. This was the first harvest from this land that had just been brought under cultivation, so it was full of lamb's quarters, but after cleaning it should yield

\footnotetext{
${ }^{15}$ In comparison, the sons of Julien and Marie Louise Mullie were able to pursue more education as they were born some 10 years later. Their youth was less interrupted by World War II and there was a high school at Arborfield. Jeanne went to the French boarding school in Zenon Park, as did Alfred and Roland. As of Grade 9, Alfred then went to Collège Mathieu in Gravelbourg, affiliated to University of Ottawa, for 5 years (1939-44), with a further year studying agriculture at University of Saskatchewan in Saskatoon. Gilbert and Joe completed their BA degrees at Gravelbourg, in 1953 and 1954, with Joe continuing for his Master's in Business Administration at the University of Western Ontario (1957). Roland and Felix completed their Grade 12 at Arborfield, with Felix also doing a year of agriculture at the University of Saskatchewan (Alfred Mullie, correspondence dated 14 February 2012).

${ }^{16}$ Ruby is an early maturing Canadian heritage wheat variety developed by Agriculture Canada in 1920. As a Registered Seed Grower, Paul Mullie would have been producing registered wheat of the Ruby and Marquis varieties. This would preferably have been planted on newly cultivated land, to avoid wild oats.
} 
some 100 bushels of seed grain. To the south of the house, 32 acres of wheat had yielded 24 to 25 bushels per acre. In the letter of 2 February 1925, Raymond observes that, with 40 hens and 4 roosters, they got 239 eggs in the month of January. At 50 cents a dozen, that made $\$ 10.00$ (\$0.50 in 1925 would be $\$ 7.43$ per dozen eggs in 2020). Raymond says that next year they will go for 100 hens.

In her letter of August 1925, Dora (Dorothy) lists what she is doing while at home during the school holidays: watering the carrots, the lettuce, tomatoes and flowers, setting the table, grinding the coffee, fetching wood, drying the dishes, learning piano and playing with Michel.

These letters also describe the weather conditions in colourful detail. In his of 4 October 1924, Jean starts out by saying that they are all in good health, but the weather is sick (malade). He continues: "On Thursday, it started to rain at 11:00 when we had four loads to thresh and we were able to work until 11:50, then we brought everything in and we escaped (nous nous sommes enfuit)" ... it continued to rain into the evening and next morning it was snowing." Jean finishes in saying: "Papa says that it is God's weather, but not of His best (Papa dit que c'est du temps du Bon Dieu mais pas de son meilleur)."

The letters describe considerable self-sufficiency. Given the importance of the garden, the letters pay attention to cutworms (vers gris) and missing a frost that affected the potatoes, corn and peas at their Beaujot and Praud neighbors. Marie-Louise goes into considerable detail in describing the clothes her mother is making. In the letter of 28 October 1925 she says that her mother has made all their winter clothes, even the coats and hats. The dress that she has made for Dorothy (Dora) is in velvet, edged with green, yellow and pink silk. Besides the garden and clothing, there was considerable self-sufficiency in meat. In hers of 2 February 1925, Marie Louise says that on Friday they did not go to school because she and Raymond had colds, so they took advantage of being home to butcher 17 roosters. She goes on to describe how these were preserved in "sealers (bocaux) that cost $\$ 1.55$ per dozen, see page 392 of the Eaton's catalogue".

On 27 May 1929, having just passed his $16^{\text {th }}$ birthday and completed Grade 10, Jean died of a ruptured appendix. At that time a ruptured appendix was often fatal, and operations were very risky before penicillin became available. The parents were sure it was appendicitis but the doctor could not operate right away. This death was a profound shock to the family. Even into her 90s, his sister Dorothy would tear-up when visiting his grave at the Saint Hubert Cemetery. As he was the second child, and first boy, Jean's death also affected the labour available on the family farm.

Another serious accident occurred in about 1937. Raymond and Michel were sharpening ploughshares in a shed with a charcoal heated forge, with the shed doors partly closed against the cold. A forge is a hot fire with special coal and a fan to heat the iron so that it can be flattened. Raymond almost succumbed to carbon monoxide from the forge. He was sick for several months after this occurrence.

Later on, the family labour force was also much affected by Michel's military service (see Box 5.2). 


\section{Box 5.2 Michel Mullie: Military Service}

Michel was called for military service the fall of 1941. He did his Military Basics in Regina for three months, then he was transferred to Brandon, Manitoba, to be trained with Heavy Artillery (cannons). He continues: I joined Active Service as the Nazi had already invaded Belgium and France where many of my first cousins were living. After our training, we got our embarkation leave to come home for three days to say "good bye" to my parents, brother and sisters. This was hard.

Back in Brandon we were all confined in our own barracks waiting to board the train and ship to go overseas. During the waiting period, two soldiers got the mumps and therefore this soldier and the eleven others from the same barrack were quarantined and moved to a different building. We all twelve got the mumps and we were quarantined in this room for about one month. Our food was brought to us on a plate three times a day. By that time the ship was not going to wait for us, and the rest of the gang left for England. We each lost 15-20 pounds during the confinement and we had promised ourselves steaks when we recovered, only to find that our stomachs had shrunk to the point that we could not consume a whole steak.

I was stationed in Saskatoon to take a carpenter's course where I learned to cut wood. Back in Brandon, I got harvest leave because Raymond had the boils. I got the doctor to write a note so that I could get leave. Then in 1943, I was discharged and went to Arborfield. I had been away for two years.

After the war, I joined the Canadian Legion, paying yearly membership for 50 years and since July 2006 I have my Life Membership card.

When relating this account, Mike observed that he started his $90^{\text {th }}$ year on 16 March 2010 . He had four children, six grandchildren and six great-grandchildren, living in Saskatchewan, Manitoba, Alberta, and England.

While a tractor was purchased in 1920, and a car in 1925, the six to eight horses were the main source of energy for pulling machinery, hauling grain to town, and travel. Some eight to ten cows were used for producing milk and meat. Paul was very particular with these animals, keeping the horses and milk cows in the barn through the winter. Other families in the district, including the Beaujot family, would let the horses free to range for the winter in the open areas north of the Pipestone Valley where there was lots of hay and unused pasture. The horses would then be captured again in the spring when they were needed for field work.

Dorothy remembers milking cows as a very hard job that she did mostly with her sister Marie Louise. The long periods in the squatting position made her back sore. There were always terrible smells, and in the summer many insects. With his scientific orientation, Paul would have the milk from each cow tested for cream content. There was one cow that was particularly difficult to milk, requiring much effort to squeeze out the milk. Marie Louise and Dorothy devised the trick of diluting the sample with some skim milk so that it came back showing a low cream content. That was the end of the cow as it was slaughtered for meat instead. 
There was much work to producing cream for market. The milk had to be brought into the house and the cream separated, at first with a hand operated separator. Blocks of ice had to be brought into a coldstorage space. The cans of cream were brought to Whitewood, then in the early 1930s a truck came twice per week. The skim milk was then fed to the calves, which had to be taught how to drink from a pail. Dorothy never saw her father milk a cow, nor her mother.

Besides the produce of the garden, orchard and barn, including chickens for eggs and meat, the family collected wild berries, especially saskatoons and chokecherries, but also rose buds, currants, raspberries and strawberries. All this required much work, including picking, cleaning and preserving the fruit. Chicken meat was also preserved in jars. This required a lengthy boiling process, which in turn needed wood to be chopped and burned in the stove. Cooking itself was much work, as was cleaning up, before the invention of dish soap. Besides the family, hired help needed to be fed. When the threshing crew was working, this required two large meals per day for all the workers. The wives of the workers would sometimes help in the kitchen during the threshing.

When inspectors came to certify the registered seeds, it was not considered bribery to also feed them, in fact it was expected. Dorothy tells the story of an inspector who particularly liked canned chicken. When asked if he wanted a second serving, and knowing that the fresh meat was all gone, he replied, 'yes, your canned meat is so good, in the city we only have fresh meat'.

For a period in the late 1920s and early 1930s, there was a beef ring in which the Mullie family participated with about 20 neighbours. An animal was slaughtered each Saturday of the summer so that everyone could have fresh meat for Saturday and Sunday, then cold meat kept on ice for a couple of days, and canned meat for the rest of the week. During winter, the meat could be frozen instead of being canned. Dorothy observes that "we did not eat much pork".

The beef ring worked as follows: At the selected date, a given farmer brought their animal to slaughter, receiving then the bonus of the heart and liver. The meat would be distributed in a relay system, as far as ten miles. Once Paul Mullie forgot that it was his turn to provide the animal, and someone had to come to remind him. He immediately loaded the animal on a wagon and off to be butchered. This story is much remembered because it was completely unlike Paul to forget things or to make a mistake like this, and thus he was very fast at correcting the problem. We like to think that this reliability lives on into the next generations, in big things and in small ones.

After the beef ring, Dorothy and Marie Louise canned meat all winter long. They also canned fish, which arrived in 50 to $100 \mathrm{lbs}$. lots, after they were cleaned and scaled. Dorothy continues: We also canned chicken in the fall; done this way, the hens that had laid eggs for a year were even better than the young roasters. The process involved sterilizing the sealers, putting in cut chicken, water, salt, and cooking for several hours. The liquid jells and is very good. 
Washing clothes was once per week. In winter we preferred to dry the clothes in the basement. If they were hung to dry outside they would come back frozen stiff.

Keeping food refrigerated was a major issue in the summer. Some things could be lowered into a well. In the spring, pushing a frozen package deep into a bin of grain kept things frozen a little longer. Most families also had ice wells. An ice well is a shed, partly underground, covered with straw. Ice was collected in large blocks during winter, and kept in this protected place, covered with sawdust. Collecting the ice was a major task. A two-person bucksaw was used to cut blocks of ice from a lake that had frozen solid, sometimes to a thickness of two feet. Horses were attached to the blocks to roll them out of the lake. Cutting and removing ice could cause sudden cracking which could easily startle the horses, already uneasy on the slippery surface. The Mullie family also put water in a cistern under the old part of the house; this would freeze to a depth of six to eight feet. They would set things on top of this ice, or take pieces of ice for various purposes such as making ice cream. Of course, this ice, as with that from the lake, was too dirty to consume. This did not prevent children from sneaking ice into their mouths as a cold sensation.

Marie Louise did more of the inside work, while Dorothy also worked in the fields, as their father was adept at using all available labour. One of the jobs involved pulling the weeds that were growing in the fields. The local youngsters were hired to walk systematically through the field, carrying a bag into which they put the weeds to be burned. It was Dorothy's job to organize this work and to ensure that the young people followed her father's instructions. Many people in the district recall the times that they had made their first earnings picking weeds on the Mullie farm. Her nephew, John Mullie, recalls doing this work in the 1950s. John and Bernard would walk carefully, sliding their feet rather than stepping on the plants, collecting wild oats in a field of registered grain. They were only a little higher than the grain, and John remembers that they returned home all dusty, "looking like rats."

Other tasks involved horses, where Dorothy tells the following story: One time, I was asked to move a granary with horses. This involved backing a team of horses against a granary, ensuring that the horses did not move while I attached the building. There was the danger that I be trampled underneath if the horses bolted at the wrong time. We then proceeded forward, with much squeaking and growling of the skids over stones, frightening the horses that had to be carefully controlled not to cause the driver to end up under the granary. From my position between the building and the horses, it was amazing to look back and only see a wall following.

Dorothy: At harvest time, it was my job to pull the grain further into the bin, from the auger that just reached the corner of the granary. This was a hot and dusty job, especially as the bin filled up and I needed to pile the grain to the top, leaving only a small crawling space to exit once the bin was full. I kept wishing that I had my brothers' job, collecting the sheaves with horse and wagon in the fresh air. Later when Leon and I bought an auger, and it remained my job to haul in the grain by truck, I ensured that the auger could reach the centre of the bin. 
Raymond and Michel did most of the field work. When they were working the quarter section at Cascaden, they would have six horses pulling the cultivator, then four horses harrowing and later four horses sowing with a drill. The horses would work four hours in the morning, then there would be a two hour break as the horses were fed and rested, then another four hours in the field for the afternoon. A straw barn was used to feed and house the horses. The fields were typically about 40 acres, with summerfallow for one year and crops for the next two years. During threshing time, there were typically five teams of horses, with each team consisting of one man, two horses and a rack.

The main implements were plough, harrows, cultivator, drill and binder, with the threshing machine being shared across neighbours. The Mouldboard plough was used to break up the soil after harvest, and to kill the remaining weeds. This was a long operation with five horses pulling two ploughshares with a total width of 32 inches. Depending on the soil, we would go to a depth of about three inches. In about 1938, Michel contacted sciatica while sitting for hours on a cold plough seat, ploughing the grain stubbles in the cold post-harvest weather. He became quite crippled, needing to sleep on the floor to relieve his aching back.

When hauling grain to Inchkeith, at a distance of 10 miles, it would take three hours to bring the load in and one hour to return. If a second load was ready, two trips could be made on the same day. The sleigh used for hauling grain in winter had a brake that engaged if the sleigh backed up, allowing horses to stop on an uphill climb to catch their wind. At first, the people closer to the grain elevator could get their grain to market faster; other farmers benefited from the Wheat Board that give everyone an equal chance based on a quota system. When it was first formed after World War I, the Wheat Board provided stable prices and markets for farmers, but its predecessor the Board of Grain Supervisors, formed in 1917 , had the main objective of controlling the price of wheat for export to the armies in Europe. ${ }^{17}$

A tractor was also purchased in 1920, but it was not used much. Even in 1942 when a larger McCormick Deering tractor was purchased, seeding was still done with horses. In the section on "Agriculture and food" of the on-line Encyclopedia of Saskatchewan, it is noted that the percentage of farms with tractors was 15\% in 1921, 29\% in 1931 and 81\% in 1951. The total horses and ponies in Saskatchewan was $1,078,000$ in 1921 , but in 1931 this total was 997,000 for an average of 7.3 per farm. The total farms reached a peak of 138,173 in the 1941 census, when there were 801,000 horses and ponies, or 5.8 per farm. By 1951, there were 304,000 horses and ponies, or an average of 2.7 for the 112,200 farms.

Before the availability of motors, horses and manpower were used. For instance, two horses were tied to a rotating shaft which then could be connected to a pump to draw water from a well. On the Mullie farm, in the period 1915-25, this system was used to provide water to cattle and horses twice per day. A similar system with eight horses would provide power to run a threshing machine.

\footnotetext{
${ }^{17}$ Leon hastens to add that, in his view, the Wheat Board has outlived its utility: with computers and the internet, farmers are now able to keep track of prices and many would prefer to have more control over the markets for their products.
} 
In about 1930-40, the Mullie family had constructed a windmill to generate electricity. A six-volt generator was on top of the windmill with wires going to batteries in the basement of the house. When the batteries were fully charged, a magnetic system automatically cut the circuit. This was used mostly for lights in the house, but it could also be used to iron clothes when the wind was blowing, or pump water from the well. All this was constructed locally, using a generator and batteries from old cars, and constructing the propeller with wood.

Paul was also ingenious at arranging not to pay taxes. He would show sufficient expenses, including paying for the labour of his children, and eventually giving things away rather than having to pay an inheritance tax.

In the later 1930s, Paul was still under 55 but already quite hard of hearing. His children had much difficulty with his strictness. He would require that every last seed be removed from the cracks in the granary when it was being cleaned. He also required that binder canvases be placed on the bottom of the racks that were collecting the sheaves at harvest, to ensure that weeds not be spread in the fields. These binder canvasses, with laths across them, made the work difficult because the fork used to throw the sheaves into the thresher would often get caught under a lath. After spending several days in the heat and dust cursing these canvases, Raymond took action and threw the canvases into the thresher. 'Swoosh' went one canvas as it was being threshed, and everyone was cheering, then 'swoosh' goes the next, and a third one, until all the canvases from his rack had been accidentally threshed and taken out of circulation ${ }^{18}$.

When the droughts came in the 1930s, Paul's farming techniques ensured some harvest even when most surrounding farmers had minimal crops. There was still much blow dirt from the fields, partly because Paul would cultivate the summerfallow as soon as there were weeds growing. The farm yard was well protected with trees. One could see the dust in the air, but it did not come into the house.

During this time, Dorothy's work on the farm was particularly intense, especially after her brother Michel was called for military service. Her sister Mary Louise looked after the household work while Dorothy did farm work. She would operate machinery with up to six horses, milk the cows, supervise kids pulling weeds from the fields, shovel the grain back from the auger into the bin at harvest time, and also help with the numerous household chores.

Dorothy especially remembers the following story: As I was out in the field with a team of six horses, a young horse that was in the team for the first time suddenly decided to lie down after I had untied the hitch to the cultivator. The job was finished so the young horse thought it was time to lie down. However, by lying down the horse broke the lines that controlled the entire team. Losing control of the team was a serious situation as they could bolt and drag me behind, even killing each other, if they

\footnotetext{
${ }^{18}$ There were cases of worse accidents with threshing machines. To celebrate the end of the harvest, the men would sometimes throw their well-worn pants in the thresher. There are stories of matches in their pockets starting a fire that would burn the nearby straw and grain, destroying the harvest.
} 
panicked and ran uncontrolled in the field. I talked quietly to each horse to keep them under control while unhooking one horse at a time from the team. As each horse was unhitched it went toward the barn on its own. As my father saw the horses coming home, he knew that something was wrong and started out to help, but by then the whole problem had been solved, one horse at a time. I was so shaken by the traumatic experience, that I could hardly walk, let alone explain to my father what had happened. This certainly confirmed the importance of talking softly to a horse to quiet it down. This not only works for horses! ${ }^{19}$

\section{Children's marriages and retirement}

As the war ended, the children of Paul and Julienne Mullie married in quick succession: Mike and Jeanne Mullie on 28 December 1944; Marie Louise and Philippe Laforge on 11 January 1945; Dorothy and Leon Beaujot on 14 July 1945; and Raymond and Maria Mullie on 19 June 1946. Mike and Jeanne were married at Zenon Park and the others at Saint Hubert. Besides Mike and Jeanne at Arborfield, Marie Louise and Philippe lived at Zenon Park, thus two of the families were at Saint Hubert where their parents lived and the other two were $\mathbf{3 0 0}$ miles north where Julien and Marie Louise Mullie lived. This promoted the continuation of the strong relationships that had been formed in the earlier generation.

These families were also part of the post-war baby boom, with a total of 28 births between 1945 and 1965. By the time of Julienne's death on 12 November 1959, at the age of 81 , there were 27 grandchildren. At Paul's death on 9 June 1967, at the age of 86, all 28 grandchildren were born. In the next generation, there would be 53 great-grandchildren of Paul and Julienne, born between 1967 and 1998.

Soon after Raymond's marriage in 1946, Raymond bought the farm and much of the resulting inheritance was divided among the three other children. Dorothy had already purchased a quarter section south of the Mullie farm, and Dorothy and Leon acquired the adjacent quarter (W $1 / 2$ of 19-14-3). Jeanne had received a quarter section near Arborfield (SE of 16-48-11) as an inheritance from Jeanne's parents, and Michel and Jeanne purchased two other quarters (SE of 13-48-12 and SE of 24-48-12), one through the Veterans' Land Act, and one through a loan. ${ }^{20}$ Philippe Laforge had bought a home quarter (NE of 14-47-12) in 1936; after their marriage, Philippe and Marie Louise (née Mullie) purchased two other quarter sections (NW of 13-47-12 and NW of 12-47-12). The acquisition of these quarters in 1946 and 1947 would suggest that the parents of Marie Louise could well have helped in the purchase. ${ }^{21}$ At the occasion of Dorothy's 90 birthday, Michel (now called Mike) was asked why they had moved to Arborfield. Of course, Jeanne's mother played a role, wanting to have her only daughter nearby. But Mike said he wanted to "get out of there", referring to his father's domineering attitude.

\footnotetext{
${ }^{19}$ For Dorothy's own audio-visual account see The Fireside Film Company, 2009, Leon \& Dorothy. FiresideFilmCompany.com.

${ }^{20}$ Michel and Jeanne Mullie purchased this farm from Joe Pelletier.

${ }^{21}$ Email communication from Art Laforge dated 10 May 2020.
} 
Paul and Julienne continued to live in their home with Raymond's family until 1952 when the retired parents moved to a rented home in Whitewood. After Julienne's death in 1959 at the age of 81, Paul lived in alternate months with the families of Raymond and Maria and of Dorothy and Leon, then he lived continually with Raymond and Maria. In the fall of 1965, he moved to the Saint Joan of Arc Nursing Home in Saint Hubert where he died in 1967 at the age of 86.

After Julienne's death, Paul had sold all his remaining possessions and divided his remaining funds among his children. This meant that he was now dependent on his children and on his Old Age Security income. This achieved his goal of giving his money to his children rather than as taxes to the government. When he moved into the nursing home, the four families shared the costs.

\section{Memories of Paul and Julienne Mullie}

As of the early 1940s, Paul started to lose his hearing. Sylvain Dumonceaux remembers that around 1945 Paul was wearing a hearing aid with a listening device on his chest. When speaking to others after church, he would say "Parlez ici" (talk here) referring to the device on his chest. By the 1960s, the family had to shout or make signals, like moving a hand towards the mouth to indicate that it was time to come for a meal. It was probably at about the same time, in the early 1940s, when they were about 60 years of age, that Julienne became diabetic. When they were home, Dorothy or Raymond would give their mother insulin through a needle, but once she was in Whitewood she did this herself. Later in life the diabetes affected her eyesight. She would listen to the French station or classical music on the radio. Being hard of hearing, Paul would read as a pastime.

Paul is also remembered as someone who could be a good actor and comedian at social events. He was a favorite to be master of ceremonies at "La fête des rois" at Saint Hubert. He would be happy to join in the singing at birthdays. As he joined the family in the morning he would say: "Bonjour en compagnie". His favorite swearing expression was "Bon sang, bon sang." He was very particular in how things should be done, especially on the farm. He could be very demanding and tough on his children. It was said that he had developed this attitude when he had been charged with managing the agricultural work of delinquent youth at a Belgian reform school. As his hearing difficulty increased, he would give instructions in much detail, then ask to have the instructions repeated ("répétez un peu"), to the great annoyance of his children.

At their home in Whitewood, Paul had a large garden and converted the rest of the yard to potatoes. He sold potatoes in town, especially to the Chinese restaurant. This meant that there were no flowers in their garden, nor grass on which the grandchildren could play. His devotion to productive work continued when he was living with his children. He would often ask what he could do. Dorothy once asked him to extend a row of raspberries. He did this with much delight, but it first required that he dig a deep trench which had to be filled with manure. When he spent a significant time with Marie Louise and Philippe's family, he asked for a pair of gloves and spent two days in the raspberry patch, removing the old stocks and cleaning up the patch. 
In a letter posted from Whitewood on 8 December 1954 to "Our dear family in France," Paul once again pays much attention to his orchards:

You must remember that at the farm in St. Hubert I had an orchard and an adjacent vegetable garden at home and an acre of orchard 200 to 250 meters from the house. Raymond took over the farm in 1947 and this last orchard in 1953. I have retained the other, I take good care of it and I help to maintain the one acre during the time I have when I am on the farm. This year as last year, I made the shuttle since the spring to uncover the strawberries and bring some here, until the fall when I cover them and bring raspberries which I winter here in the ground to plant at the thaw the following year. In summer I do what is necessary both here and on the farm. I spent a hundred days in each place. Julienne a week. She only goes out on Sundays to go to Mass. I go to the village 2 or 3 times a week to pick up the mail, the groceries, the butcher, the baker, and once a month collect our 2 checks, each of $\$ 80$ (\$750 in 2018 dollars) for old age pension and to pay for the use of electricity.

Julienne was a very outgoing person, making sure to socialize with community members who were not French speaking. She is remembered as creative, sociable, enjoying laughter and a good conversation. As a person educated in several languages and operating a grocery store with her sisters in St. Trond, Belgium, she could hardly have anticipated all the hardships of setting up a household in Saskatchewan in the 1910s. Nonetheless, she rose to the challenges. She was particularly well respected in the community, especially for her willingness to speak her mind when she thought the priests and nuns were off base on how best to educate and raise a family. Asked by the priest how the children were doing after moving from the school at St. Hubert run by nuns to the English one-room public school at Golden Plain, she quipped: "at Golden Plain the teachers know how to teach." This was in contrast to the nuns who were not trained as teachers, and sometimes had been placed in the convent against their will, by their parents. Julienne is also remembered as someone who went out of her way to be inclusive toward others, such as people who were not French-speaking, or who were not Catholic.

Having contacted diabetes at about age 50 , Julienne eventually had very poor eyesight. She was still able to take care of the house in Whitewood, where the couple moved in 1952, until her sudden death in 1959. There were certainly difficult times, especially with the premature death of her son Jean in 1929, just after his $16^{\text {th }}$ birthday.

Almost daily, she would have a telephone conversation with Dorothy, her youngest daughter, whether they were on the same telephone party line living a mile apart, or at the distance of 20 miles to Whitewood. At the end of a particularly hectic day, Dorothy would say: "Oh, I forgot to call Grandma today."

In her younger years, Julienne had some unique recipes. The prohibition did not prevent her from putting homebrew in the bread pudding that she would bring to community events. When people who did not drink alcohol asked for the recipe she found ways to ignore the request. 
She would knit, crochet, embroider and cross stitch. She would put "M.S." for Mullie - Smets on linens. She made five crochet bedspreads for double beds: one for herself and one for each of her children as they married. As the grandchildren started to arrive, she knitted little white sweaters for each of them. Eventually, with her poor eyesight, she could not keep up and the sweaters were passed on to younger children, some even surviving to following generations.

As the first-born granddaughter, Raymond's daughter Betty has other strong memories of her "Bonne Maman". She had long hair that she tied in a bun (chignon), and always wore her beautiful engagement ring. She would sometimes walk with her hands behind her back. She liked to play singing games with her grandchildren. She would form a circle with the children, crossing arms and holding hands with the persons standing next, then do a zigzag singing: "Sciez scions les vaches s'en vont. A Saint Hubert et encore plus loin. Ouche, ouche ... ." Then all would put their hands in the air, laugh and do it again. Other favorites were "Sur le Pont d'Avignon" and "Frère Jacques."

Betty recalls that her grandmother was very organized, putting things away in the right places, which was important as she was losing her eyesight. She would say: when I am no longer good ... I don't want to live any more. She got her wish, dying suddenly of diabetes, without becoming dependent. 


\section{Appendix 5.1 Letters written by Marie Louise, Jean, Raymond and Dorothy, 1924-25}

Below are four sets of letters written by the children of Paul and Julienne Mullie to the family of Paul's brother, Julien and Marie-Louise Mullie, in Arborfield. In February 1924, Julien had married the widowed Marie-Louise (née Duthoit) and they were now in Arborfield with Jeanne, the daughter of Marie-Louise from her previous marriage. The letters that are partially transcribed below were written on 4 October 1924, 2 February 1925, August 1925 and 28 October 1925. In February 1925, Marie Louise was 13, Jean (John) 11, Raymond 9, Dorothy (Dora) 7, and Michel 4. Their cousin Jeanne was almost 3 years and Alfred was two months.

Each set of letters from a given date are written on two sides of one sheet of paper. Probably to save on postage, there is also writing in the margins. Some of the paper has deteriorated. Annette Gunn discovered these letters in 2021 among things that her grandparents, Julien and Marie-Louise Mullie, had kept. Annette observes that the paper is at least 96 years old, and there are signs having been stored in damp cellars and chewed by mice. The first two letters start with typed entries by the children and handwriting in the margins by one of the parents. The two other letters were handwritten. The space bar was not always working properly on the typewriter, and it was an English keyboard with no accents. The re-typing below takes advantage of spell-check.

It is worth translating some of the words: criblé (screened), cassage (broken land), choux gras (lambs quarters), courrois (belts), pitch (an English word), bréchet (wishbone), bottes (sheaves), séparateur (threshing machine), battage (threshing), vers gris (cutworm).

......

\section{Le 4 octobre 1924}

Cher Oncle Julien, Tante Marie-Louise et Nenette, J'ai été à l'école cette semaine avec Dora. John aide au battage avec Maman. Marie-Louise fait la cuisine. Hier, John et Marie-Louise ont été à l'école parce qu'il a plu jeudi soir. Aujourd'hui il neige un peu.

Nous avons battu 5 acres de lin qui ont rapporté 138 minots, cela fera environ 100 minots de bonne semence une fois criblé comme il faut.

Le lin a été semé sur le cassage que vous avez vu. Il était plein de choux gras.

Au sud de la maison, 32 acres de blé ont rapporté 24 à 25 minots à l'acre....

Je vous embrasse de tout cœur.

Votre neveu et cousin, Raymond

Chers Parrain, Tante et Cousine, Je suis content de vous dire que nous sommes tous en bonne santé mais le temps est malade. Jeudi il a commencé à pleuvoir à onze heures. Quand il commençait à pleuvoir, on avait quatre charges à battre et on a battu jusqu'à dix minutes pour douze heures. Alors nous avons rentré tout et nous nous sommes enfuit. 
Il a plu jusqu'au soir et hier il a plu un peu au matin et aujourd'hui quand je me suis réveillé je vois qu'il neige. Il a neigé jusqu'à maintenant et à midi Raymond et moi ont été s'amuser à la cour avec les skis que Lous (sic) nous a laissés. Papa dit que c'est du temps du Bon Dieu mais pas de son meilleur.... Avez-vous reçu des lettres de Warneton, Ploegsteert? ...

Les hommes sont très rares pour le battage, nous n'en avons qu'un en plus de notre Hongrois. ... Votre Filleul (godson), Jean

Très chers Oncle, Tante, et Jeanne, Je veux aussi écrire quelques mots. Depuis que le battage a commencé je suis ménagère. Il a bien fallu. Nous sommes à court d'aide. Aussi, Maman, John et moi nous nous efforçons à aider Papa. Maman aide à mettre les courrois et pitch, John soigne le tracteur et le séparateur pendant que Papa met les bottes dans le séparateur.

Maman a commencé à faire un paletot pour elle dont voici l'échantillon, elle a déjà fait les culottes de John, Raymond et de Michel. Elle va aussi faire des robes chaudes pour Dora et moi.

Ce soir Papa a dansé avec Dora et John. Vous voyez par là qu'il est en bonne santé, comme je vous souhaite tous.

\section{Bonsoir, bonne nuit, bons rêvés et baisers de Marie-Louise}

\section{St. Hubert Mission, 2 Fév. 1925}

Chers Oncle, Tante, Jeanne et Alfred, Nous avons reçu les chapelets Mardi 27. Nous vous remercions beaucoup. Ils sont bien jolis. ... Nous n'avons pas eu de nouvelle de Tante Emma depuis le mois de juin. ...

Vendredi nous n'avons pas été à l'école parce que Raymond et moi étaient grippés, alors nous avons tué 17 coqs. Nous avons acheté une douzaine de bocaux en verre qui ont coûté 1.55, page 392 dans le catalogue de Eaton. On peut mettre un coq dans chaque bocal excepté la tête, cou, les os du bréchet et poitrine. ...

Le 6 janvier nous avons recommencé le concert. Michel a dit une petite fable de 6 lignes, John, "Le corbeau et le renard " pour faire rire le monde, et Raymond " Les Vingt Sous du Bon Dieu ». ... Comme d'habitude, les jeunes filles passent des morceaux de gâteaux. Dans deux de ces morceaux il y avait un bouton pour voir qui serait le roi et la reine. Papa et Mme E. Beaujot ont été. Ils ont été sur le trône et on les a couronnés. Léon et Joseph ont joué la musique alors le roi a fait son discours sur les incidents de vie de roi en prenant " L'histoire de l'épée de Damoclès ». Alors il a chanté « Monsieur la Palice est Mort ". Il a aussi dit "Le $Q$ de Catherine ". ... Des hommes ont chanté. Après nous avons tous chanté. Le roi a aussi vendu aux enchères un joli gâteaux. Nous sommes revenus à deux heures du matin.

Votre nièce qui vous embrasse, M-Louise

Chers, Oncle, Tante, Jeanne et Alfred, ... Nous avons 40 poules et 4 coqs. Pendant le mois de Janvier nous avons reçu 239 œufs à 50 sous la douzaine ( $\$ 0.50$ en $1925=\$ 7.43$ en 2020), nous en avons pour $\$ 10.00$. Nous allons essayer d'avoir cent poules.

Votre Neveu, Raymond Mullie 
Chère Nenette (Jeanne),

Je t'envoie un gros baiser à ton Papa à ta Maman et à ton frérot Alfred. Hier Papa a dit à Michel d'écrire toutes les lettres qu'il savait. Quand Papa a regardé ce qu'il faisait, il copiait les lettres du pot de confiture. Nous avons bien ri. Comment va ton petit frère et ta poupée?

Un baiser de Michel et de ta cousine, Dora

\section{Late Aug or early Sept 1925}

Chère Jeanne, Que fais-tu à la maison. Voici ce que je fais pendant les vacances. J'arrose les carottes, la salade, les tomates et les fleurs. Je mets la table, je mouds du café, je cherche du bois, j'essuie la vaisselle et j'apprends le piano et joue avec Michel.

\section{Mille baisers, Dora}

Chers Julien, Marie-Louise, Jeanne et Alfred

Je fais comme Julien quand il était « bachelor ", j'emploie le crayon parce ce que tous les plumes sont occupées. ... Je vais faire des robes pour M-L, Dora et moi, 2 paletots pour mes filles, j'ai déjà fait un pardessus pour Michel, je l'ai doublé avec la peau de mouton de Raymond. ... Michel dit que je dois dire à Jeanne que son pied est collé à son bas. II dit « Maman il ne faut pas écrire callé mais collé. Paul a commencé à couper le blé de Ruby mercredi le 12 août. ... Nous n'avons pas encore sorti notre auto cette année, beaucoup à cause que la route dans la vallée entre nous et Praud est trop mauvaise jusqu'à juin. Encore maintenant elle est raboteuse. ... Quand John et M-Louise seront plus grands ... John qui est habile à conduire le tracteur sera aussi habile à conduire l'auto. Nous parlions le 19 à Jeff Durvail (sic : Durwael) qu'on allait une fois aller en auto à Arborfield et on discutait le pour et le conte, bref cela couterait autant que le chemin de fer! Voilà notre visite pour Arborfield remise. ... Vous avez eu plus de succès que moi avec ton jardin, les vers gris et les poussins ont mangé beaucoup. Ici rien n'a été gelé ... mais chez Beaujot et Cotton (Michel), les pommes de terre ont été tout gelé, chez Praud le haut du maïs. Julienne

\section{Oct. 1925}

Chers Oncle, Tante, Jeanne et Alfred, Il y a longtemps que vous nous avez pas écrit ... Avez-vous fini de battre? Nous avons fini. Nous allons à l'école tous les jours en voiture. ... nous allons essayer de passer nos examens ... gouvernement en Juin 1926. ...

Maman a fait tous nos vêtements d'hiver même nos paletots et chapeaux. Je vous envoie des échantillons. Maman est très habile. Je voudrais bien être comme elle. ... une paire de culottes pour John et Raymond. Elle a très bien réussi. Elle réussit toujours. ... La robe de Dora est en velour vert... bordée avec la soie verte, jaune et rose ....

J'espère que Jeanne et Alfred sont toujours des grands amis ensemble.

Chaqu'un un gros baiser, votre nièce Marie-Louise.

\section{Ma Chère Jeanne,}

Est-ce que Alfred met encore son pied dans sa bouche? Combien de dents a-t-il? Est-ce qu'il pleure beaucoup, j'espère pas. ... Dora 


\section{Chapter 6 \\ Leon and Dorothy Beaujot: The Family Farm, 1945-1985}

Léon René Paul Beaujot and Dorothée Adeline Marie Thérèse Mullie were married on 14 July 1945. Since the Saint Hubert Church was undergoing renovations, the marriage was in the chapel of the Sainte Jeanne d'Arc Nursing Home. The wedding dance was held in the implement shed of the Mullie farm, with a flooring of newly placed planks. At the time, Leon was on composite farm leave from his army base in Sussex, New Brunswick, for 5 June to 4 December 1945. With the war coming to an end, the leave was extended to 4 March 1946 and his Discharge Certificate was signed in Regina on 29 January 1946.

The places of birth of Dorothée and Léon were six miles apart, both as second-generation Canadians. ${ }^{1}$ Their parents had come to Saint Hubert in 1892 (Félicien Beaujot), 1910 (Bertheline Sénéchaud) and 1911 (Paul Mullie and Julienne Smets). Dorothée was fourth born in her family, on 19 July 1917, and Léon was third born in his family, on 29 September 1919. Both Léon and Dorothée had older sisters born within five weeks of each other (Flora Driscoll born on 25 April 1911 and Marie Louise Mullie born on 2 June 1911). Both of these births were assisted by Marie Adele Bellehumeur, who was referred to as a Métis midwife in the Beaujot family and as a helper when the children were born in the Mullie family.

The geographic proximity at birth was interrupted when Léon was three months old. The Beaujot family sold their land at St. Hubert and moved to California to find a climate that would alleviate Félicien's debilitating migraine headaches. After the near disappearance of the Beaujot family in California with the Spanish Flu, the family was back within the year to St. Hubert, on what is known as the Daley farm (SW 25-14-4), when Léon was one year old and until he was six. During these five years, the two families were living less than two miles apart.

Dorothée and Léon have a common memory of an occasion during this period when she was seven and he was five years old. The St. Hubert community had the tradition of a Jour du Roi where a King and Queen of the event were chosen by a lottery. This lottery was partly rigged to ensure proper leadership of the event. Paul Mullie was a natural for the stage and he was to be chosen for the role of King of the event. Julienne was to be Queen, but by some accident, Léon's Tante Modeste Beaujot was instead chosen. Contrary to Paul, Tante Modeste had never been on stage and she laughed for the duration of the event, with Paul holding his cool as he invited various people to sing or perform for the community. In her description of this 6 January 1925 event, Dorothy's sister Marie Louise says that the family arrived back home at 2:00 am. ${ }^{2}$

\footnotetext{
${ }^{1}$ Dorothy was born at her parents' home (SE quarter of 30-14-3) and Leon at his parents' home (East 1/2 of 35-14-3)

2 The letter that Marie Louise wrote on 2 February 1925 gives more details including titles of stories (Appendix

5.1). By the early 1930s, these Jours du Roi at Saint Hubert had come to an end.
} 
In 1928, the Mullie family were invited to visit their previous Beaujot neighbours, now living in the Handsworth district. They first went to church, which was in the Handsworth school, then along with the priest they had dinner at the Beaujot home. Dorothy remembers the priest saying to her mother that Dorothée would make a lovely nun someday and she was astounded to hear her mother agree. After the priest left, her mother told her that she had only said this to shut up the priest.

When Leon was aged 16, in the fall of 1935, the Beaujot family were back in the St. Hubert community. Dorothy remembered her older brother Raymond telling her that this young man was Leon Beaujot, who had been their neighbour some ten years earlier. ${ }^{3}$ In 1939 the Beaujot family moved to the Yvon Bourhis farm, west of Saint Hubert, across the valley from the Mullie farm. At that time, Leon was working for various farmers in the Whitewood district. This farm work came to include work on the Mullie farm, such as hauling manure and helping with harvest. Leon recalls:

It was a lot of fun working there, and we would also play ball and go to dances together. Paul Mullie never treated me as harshly as he was with his own children. One day, Paul got me to dig a six-foot hole in the garden to plant an apple tree. It was just like him to use such a big hole to plant orchard trees. Dorothy took advantage of the hole and stuffed hay into some clothes to make it look like there was a dead person at the bottom. She was always playing tricks, says Leon. We started going out together in 1938.

\section{Establishing home and farm}

From her earnings on her Dad's farm, Dorothy purchased the quarter section which was adjacent and to the south of the Mullie farm (NW $1 / 4$ of 19-14-3 West of $2^{\text {nd }}$ Meridian). With her brother Raymond, Dorothy seeded this land in the spring of 1944 . In November 1944, Leon borrowed $\$ 1200.00$ from his mother, $\$ 500.00$ from his brother Albert and obtained a loan of $\$ 2,500$ from the Credit Union to purchase the second quarter of this property (W $1 / 2$ of 19-14-3). The total price for the half section was $\$ 7,275.00$ paid as of January $1945^{4}$. The farm was purchased from Fred and Lillian Elkington. ${ }^{5}$

On the homestead map, Section 19-14-3 is labeled as C.P.R. land with the date of 23 June 1901. The house had been built by the Brown family. In 1913, the farm was rented by Octave Smeets ${ }^{6}$ who farmed there for one year with the help of Jeff Durwael, both bachelors at that time. There had been another occupant before the farm was purchased by the Elkington family in 1918. The house had probably started as one-room to which a two-story addition was later attached.

\footnotetext{
${ }^{3}$ By their teen years, young people were typically speaking in English to each other, and thus the names Dorothy and Leon will be used.

${ }^{4} \$ 1.00$ in $1945=\$ 14.51$ in 2018 (\$7,275 in 1945 would be $\$ 105,560$ in 2018).

${ }^{5}$ Fred Elkington had immigrated from England in 1900 as a Barnardo boy, at age 10 (Langbank and District History Committee, 1984: 220). After working in the Golden Plain District, he established a homestead in the Willow Bunch area and farmed there until 1918. In that same year, he married Lillian Shambrook and bought the farm on west half of 19-14-3. He farmed this half section until 1944 when he sold it to Dorothy and Leon Beaujot and bought a farm in Kenton, Manitoba.

${ }^{6}$ Octave Smeets would marry Marie Havelange in 1914 (Memories of Saint Hubert 1980: 203-4). Their daughter Maria Smeets would marry Raymond Mullie.
} 
Paul Mullie had agreed that this was a good farm to purchase. There was a creek along the east side, making for good drainage for the fields ( 210 acres) and water in the pasture (110 acres). Besides the house, the farm site included an established shelterbelt of trees, a small low barn, a recently-built shed and some small granaries. There was also a well and dugout providing water for the home and livestock. Other than the pasture area, the farm land was sufficiently flat and cleared of trees so that it could be farmed with equipment available at that time. The fields consisted of good quality clay loam soil. However, Mr. Mullie had noted that there was also plenty of wild oats which would be hard to control. The fenced pastureland was important to the mixed farming (cattle and grain) that characterized prairie farms at that time. Having a reliable water supply in the pasture was also important. The creek however was not spring fed so in a dry year the cattle would depend on the water accumulated in deep holes along the creek bed. Having the pasture so close to the farm site was a further asset.

When his parents had stopped farming and moved to Saint Hubert in 1944 , Leon paid $\$ 55.00$ cash, and obtained a \$200.00 loan from them @3\% interest, to purchase some of their farm equipment: drill (used for seeding), binder, rake and wagon box. In Leon and Dorothy's account book for 1944-48, other farm equipment is indicated as purchased over the period Nov 1944 to March 1946: cultivator for \$20.00 (at the Praud sale), harrows and cart for $\$ 16.00$ (at Miles' sale), sleigh for $\$ 60.00$ (at Co-op), wood water pump for $\$ 25,00$ and Viga Cream Separator for $\$ 26.00$ from Eaton's.

The house had possibly started as a small one-room house, possibly $12 \times 12$ feet, that eventually became the kitchen. Later, a two-floor addition was built, with each level about 24 feet by 16 feet. Besides the kitchen, the downstairs consisted of a living room and parlor, with three bedrooms upstairs. There was also a dirt basement used as a cold storage area. Dorothy observes: the basement was accessed through trap door in the pantry. It was dangerous to fall in when the door was opened. Eventually, we installed a light that turned on when the trap door was opened.

When Leon and Dorothy purchased the property, the house was already equipped with a stove for cooking and heat. The purchase of additional household furniture was the subject of an often-repeated story. After their wedding, Leon and Dorothy went for their honeymoon to the Regina Exhibition and to purchase furniture. They travelled in the Model A Ford that they had purchased from Paul Mullie. At the Exhibition, Leon was duped into trying to multiply his funds, but he got caught in a rip off. The newlyweds nonetheless came home with a dining room table, 9 chairs and dresser (for a total of $\$ 54.30)$. Their expense book for 1945 also shows a kitchen stove bought in Regina for $\$ 53.60$, and later a china cabinet for $\$ 37.39$. There is also an entry of $\$ 19.97$ for telephone rental and installation fee, and $\$ 101.78$ for municipal taxes.

During their first winter in the house, with no children, quoting Leon and Dorothy:

When we first lived in our house, we had set the bed in the living room so that we only needed to heat this one room during the night. The piano, which Dorothy's parents had given us, was at our head. One night we heard sounds from the piano. We both woke and asked each other if we had heard the piano playing or had we been dreaming. It was quite scary in the dark, especially 
as we heard the sound again. We lit a lamp and eventually saw a mouse scattering away, as frightened as we were by the sound of its footsteps on the piano strings.

Much happened in their first year of married life. On 8 January 1946, Leon's father, Félicien Beaujot died of pneumonia at the Joan of Arc Home. On 29 January they travelled by train to Regina to sign Leon's Discharge Certificate from the Canadian Army. For this mid-winter trip, Leon's brother Albert drove them to Inchkeith, then Albert looked after the farm for two days. Leon and Dorothy stayed the night with the United Grain Growers agent in Inchkeith, then they took the train to Regina, staying at Ernest and Anita Gatin's for another night. Then on 22 April 1946, their first child was born, in Whitewood.

For their first year of farming, in 1945 , horses were used for both seeding and harvest. They started with eight horses. In 1948, they purchased an Oliver 70 tractor (see Table 6.1 at the end of Chapter 6). With this tractor, horses were no longer used for pulling farm implements in the field ${ }^{7}$. They also purchased a swather, using the tractor to do custom swathing for neighbours. ${ }^{8}$ They slowly built up a small herd of cattle with purchases from neighbours. For instance, in 1946 they paid $\$ 90.00$ for a cow and calf purchased from Leon's parents and $\$ 260.00$ for 6 calves purchased from Ernest Gatin. A two-month old dog named Pearl was bought on 15 December 1946 for \$2.50 (\$36.25 in 2018 dollars). In 1947, six cattle were bought for a total of $\$ 477.10$.

The income for 1945 shows $\$ 500.00$ for Dorothy's wages at the Mullie farm plus $\$ 988.25$ on sale of wheat, oats and brome grass seed. In 1946, the income shows an army discharge payment of \$151.71, the sale of three cattle for $\$ 206.39$, work for Raymond Mullie and custom combining for $\$ 138.22$ then 1088 bushels of wheat sold for $\$ 1277.96,35$ dozen eggs $^{9}$ sold to grocery stores for $\$ 11.87$, and $\$ 40.00$ in Family Allowance cheques (8 months @ \$5.00 per month).

It is noteworthy that these early account books did not keep farm and home accounts separately. It was a family farm and thus home and farm were one operation. In the 1949-59 account book, the categories of expenditures were: kitchen, clothing, fuel \& lights, Misc., farm, tractor, truck, car, livestock, and improvements. While it was on the "farm" side of the ledger, the category of "improvements" included things for the house, like a kitchen table, and for the farm, like "brush breaking" and property taxes. The 1953 ledger also includes "Continental insurance for Roderic and Norbert" as improvements. It is as if these expenditures, including investments in future farm labour, were "improvements" to the family farm.

\footnotetext{
7 The article on "Agriculture and food" of the on-line Encyclopedia of Saskatchewan, indicates that the percentage of farms with tractors increased from $15 \%$ in 1921 to $81 \%$ in 1951, while the number of horses and ponies decreased from an average of 7.3 per farm in 1931 to 2.7 in 1951. See also Fowke, 1957: 81.

8 The account books show a payment of $\$ 300$ for combining in 1950 , before purchasing their own combine in 1951 . In 1949, they paid Dorothy's brother Raymond $\$ 413$ for combining. The 1950 operation was probably by custom combiners who had started in the US, working their way north with the maturing crops.

${ }^{9}$ The grocery stores were paying $\$ 0.34$ for a dozen eggs, which would be $\$ 4.86$ in 2018 . Before eggs were mass produced, individual farmers could make a reasonable profit from small-scale egg production.
} 
In 1947 they purchased a used Model A Ford for $\$ 200.00$ which was traded for a 1948 Dodge in 1949 with an additional payment of $\$ 2050.00^{10}$. In 1947 , a Warm Morning Heater was purchased for $\$ 77.00$. A major household expenditure was for coal: $\$ 94.29$ in 1947, \$88.19 in 1948. On 22 February 1948, there is the very interesting entry of $\$ 5.00$ for "Cross - Snow Plane Trip", much remembered as the way baby Norbert and mother came back from a snowy and cold 11 February birth at the Whitewood Hospital.

In 1948 , a 32-volt electrical system was purchased for $\$ 300$ plus $\$ 21.00$ in freight, and $\$ 55.14$ worth of electrical equipment was bought from Remi Praud. There is a side entry in the November 1948 accounts indicating that the cost of the power plant, including wiring for electricity in the house, was $\$ 395.75$. Dorothy adds that this was the best purchase they ever made, giving them lights in the house and barn, an electric toaster, and the possibility of using motors for churning butter, washing clothes and cleaning grain.

Other notable expenditures in 1948 for the farm include $\$ 180$ for seed oats and barley from Montie Cross, and a Hereford heifer and steer purchased for $\$ 185$. A weed sprayer was purchased in March 1948 for $\$ 222$ with 2-4 D purchased in May for $\$ 470$. There is a labour payment to Albert Beaujot for $\$ 82$ and another for combining and hauling to Roland Mullie for $\$ 200$. The municipal taxes amounted to $\$ 183$.

On the income side, the entries for 1947 amount to: $\$ 1,966$ for grain, $\$ 918$ for cattle, $\$ 478$ for labour and custom work, $\$ 105$ on the sale of three horses, $\$ 68$ for eggs, $\$ 32$ for cream and $\$ 4$ for butter (see Table 6.2 at the end of Chapter 6$)$. There are also entries totaling $\$ 60$ for Family Allowance and $\$ 1,200$ as an inheritance gift from Dorothy's father. The main sources of farm income were grain (60.4\%), cattle (20.4\%) and labour (13.4\%) with eggs, cream and butter comprising $2.8 \%$, and the sale of horses $2.9 \%$. The 10 December 1948 entry indicating the sale of three horses for $\$ 105.00$ is interesting because it signals that horse power was no longer of value to the farm operation. Horses were still important for transportation during the winter, and for children going to school. Also noteworthy is the accuracy of these accounts, with some 70 entries totaling a 1947 farm income of $\$ 3,566.10$ plus $\$ 1,260$ in transfers.

The 1948 income from grain was much reduced, to $\$ 981$, with only $\$ 205$ from sales and the remainder from adjustment payments from the 1947 crop. The 1948 crop was sold in the 1949 calendar year. This shows the variability of income from grain, and the value of livestock and mixed farming to stabilize income. The total farm income was down to $\$ 2,258$, with $43.0 \%$ from grain, $37.4 \%$ from cattle, $7.0 \%$ from eggs, $6.5 \%$ from labour and $6.0 \%$ from cream. This farm income was subsidized by a $\$ 1,447 \mathrm{gift}$ from Paul Mullie and Family Allowance of $\$ 105$ over the year, for two children. While the total income was in line with total expenses in 1945-47, the 1948 expenses exceeded the income by over 40\%, despite the large transfer from Dorothy's parents.

\footnotetext{
10 The expense entry for 19 September 1949 shows the purchase of a 48 Dodge car will a millage of 15,950 for $\$ 2050.00$. This would represent a 2018 value of $\$ 22,400.00$ and about a third of total expenses for 1949 .
} 
Noteworthy in the income for 1950 was the breeding of six sows of neighbour farmers in January by Ravine Bank for \$2.50 each, then in September the boar was sold for \$65.41 (525 lbs @\$0.13). While 1948 was the last year showing income from eggs (e.g. 45 dozen @ $\$ 0.34$ per dozen on 24 January for a total of $\$ 15.44)^{11}, 1952$ was the last showing income from pigs. Three horses were sold in 1948 for a total of $\$ 105$, and two others in 1952 and 1954.

In 1952, Leon and Dorothy added to their house by removing the old kitchen and building a two-floor addition with a full basement. The extension was probably $20 \times 28$ feet, including an entrance area, bathroom, kitchen and dining area ${ }^{12}$. The old part of the main floor was converted from two rooms to one large family room about $24 \times 16$ feet. The upstairs now consisted of three large bedrooms plus a small one. Leon's brother Albert was the main designer and chief of operations. ${ }^{13}$ George Brûlé brought his tractor and scraper to carefully excavate the area against the house where the extension was to be built. Various other neighbours also helped, especially when the cement was being poured for the basement walls and flooring, including a cistern.

It was exciting when the old kitchen was being demolished because no one knew what might be underneath. Norbert, at $4 \frac{1}{2}$, remembers looking on intently as the floor was being removed, thinking that a buried treasure might be uncovered. Roderic, at 6 years, remembers their mother calling Grandma Mullie to say that a crawl space had been uncovered, which was exciting because there would be less excavation needed for extending the basement. Fred recalls collecting bent nails on the ground and giving them to Uncle Albert who would straighten and reuse them. Although he was barely three years, Fred remembers that "Mon Oncle made me feel I was contributing to the work." Honory had just learned to walk and needed to be controlled from the danger of the construction area. Leona was just a few weeks and not yet crawling. It must have been quite a challenge to be without a kitchen as the house was being remodeled, with five children under seven years of age. Clearly, they were up to the challenge.

Much would happen in the remainder of the decade. Doreen was born in April 1954 and Adelin in January 1956. Just three weeks before Adelin's birth, Leon's mother Bertheline Beaujot passed away. Then Pat was born in April 1959, and Dorothy's mother Julienne Mullie died in November 1959. There was now only one grandparent left. The expanded house was now in full use, with the parents' room, the boys' room with two bunk beds, the girl's room, and Grandpa's room. After 15 years of marriage, Leon and Dorothy now had eight children, five in primary school and three at home. In the fall of 1959, Roderic was in Grade 8 at Collège Mathieu in Gravelbourg ${ }^{14}$, Norbert, Fred, Honory and Leona were at

\footnotetext{
$11 \$ 0.34$ in 1948 is the equivalent of $\$ 4.01$ in 2019 , giving a total of $\$ 182.16$ for 45 dozen eggs.

12 The original part of the house is estimated at $24 \times 16$ feet, over two floors. These estimates are thanks to Norbert.

${ }^{13}$ The account book shows an entry for 6-8 October of $\$ 4,042.75$ for material and labour for house, representing over half of expenditures for that year. On 18 October 1952, there is an entry labeled as "oil heater" for the floor furnace of $\$ 235.00$ minus the $\$ 35.00$ for the Warm Morning heater.

${ }^{14}$ Collège Mathieu, founded in 1918, was offering a bilingual program, starting in Grade 8 , operated by the Oblates of Mary Immaculate. This order of priests and brothers had founded the University of Ottawa and set up affiliated
} 
Golden Plain. Further changes would occur in the next few years, with the acquisition of more farm land, moving the house to a new location closer to Langbank, and Jeanette's arrival in March 1965 to complete the family.

\section{Help from family, neighbours and government}

Given the very limited soldier's income, the transfers from Dorothy's parents played a significant role in establishing a viable family farm. Besides the purchase of the first quarter from Dorothy's wages on the Mullie farm, and the possibility of using this quarter as security on the loan for the second quarter, the income ledgers for 1947-56 show a total transfer of $\$ 9,200$ from Dorothy's parents (with a 2018 value of some $\$ 85,000$ ). As their children were married, and their farm was sold to their oldest surviving son, Paul and Julienne Mullie transferred much of their assets to the next generation, permitting them to establish themselves in the difficult environment of the late 1940s. Some of the transfers are indicated as being "from Belgium" which would have been either the sale of property or inheritance from the Mullie and Smets families. In 1956, there is a transfer of $\$ 250.00$ that is identified as being from "Aunt Thérèse, Belgium". This is probably Julienne's sister Thérèse Smets who had died as a single woman in 1946. It was through the names in her will that we were able to re-establish contact with the Smets family in 2009.

On the Beaujot side, despite their meagre savings, Leon's parents helped with a $\$ 1,200.00$ loan for the land and equipment (with a value of $\$ 17,400$ in 2018). Leon's brother Albert also contributed much to the support of the family. As a carpenter working on his own, and then in the employ of the Joan of Arc Nursing Home in Saint Hubert, he had the flexibility of also helping with the work on the farms of his sister Flora ${ }^{15}$ and brother Leon. Besides constructing the addition to his brother's home, and the barn at his sister's farm, he was very helpful, particularly at harvest time. This also increased Albert's income, especially when he had less of his own work to do. There are entries showing payments to Albert in several of the annual accounts. During haying season in about 1957, the two brothers were using an old truck with a starter that was not working. Leon would operate the gas pedal as Albert turned the crank to start the motor. The crank was also defective, and it got stuck as the motor started, breaking Albert's arm. Leon adds:

colleges (residential schools for boys) in Western Canada. The program was called a "cours classique". Roderic had started school late and the Collège allowed him to skip Grade 7, thus catching up with his cohort. Norbert and Fred also did their Grade 8 at Gravelbourg. Norbert had missed the last two months of school the previous year, due to rheumatic fever, and the Collège allowed him to go directly into Grade 8. Dorothy's first cousins Alfred, Gilbert and Joseph Mullie had attended Collège Mathieu. Alfred was there in 1939-44 and his brothers attended in the 1940s and early 1950s. Roderic graduated from the program in 1967. The following year, the BA program closed, and the school became a private francophone high school for both boys and girls.

${ }^{15}$ In 1946 Flora and Joe Driscoll bought a home that they moved onto their farm using horses, with Albert's help. In 1947, they purchased an old hip roof barn which was dismantled, moved to the farm and reassembled by Albert Beaujot and Wal Apperley (Driscoll, 1992: 14). In about 1949, Flora and Joe borrowed money from Albert to buy a John Deere AR tractor so that they were no longer farming with only horses. In the winters of circa 1945 and 1946, Albert Beaujot brought Albert Poncelet to the Driscoll home to trap muskrats and weasels. 
Albert's arm was first broken when he was about ten years old, with an accident on the buggy. Later he dislocated his shoulder when we were racing Joe and Flora who had a team of horses and a cutter. I was on horseback, pulling Albert with a rope on skis, when he hit a rabbit that Joe and Flora's dog had chased into his pathway.

The account books also show much interaction with Raymond Mullie who was now farming the Mullie farm, especially until Paul and Julienne Mullie moved to Whitewood in 1952. Leon used some of Raymond's equipment and he also did some custom work for his brother-in-law. Being on the same telephone party line, Dorothy could dial her mother directly, without going through the operator, just by cranking the appropriate ring on the telephone. Even after Julienne had moved to Whitewood, Dorothy would call her mother almost every day. Sometimes after a particularly busy day she would say: "Oh, I forgot to call Grandma today."

Beyond the family, the farmers in the community helped each other in various ways. Sometimes this was paid, as in custom combining, and other times it was in kind, as in helping with a major construction. There was also much cooperation, as people learned to use the new equipment. Leon did spraying and combining for neighbours who needed help, or who did not have their own equipment. Emile Gatin provided electricity through re-cycled car batteries that he charged. Any major construction involved a gathering of neighbours. When there were surpluses of specific items in someone's garden, they would invite neighbours to come and collect what was not being used.

The case of a couple who came from France in the mid-1950s provides a counterexample to this cooperation across neighbours. When he was in his 20s, Denis Bardon had come from Bordeaux, to find work and experience life in the Canadian Prairies. Denis was good company and had made friends with other young men from the community. He had stayed in contact with Leon and suddenly informed that he had married and was coming out to establish himself on a farm in the Saint Hubert district. He seemed very oblivious to the imposition that his arrival represented to Leon and Dorothy Beaujot. For several weeks the young couple stayed with the Beaujot family, adding demanding dependents to an already large household, and providing little assistance in return. Leon nevertheless helped them find a farm to purchase. The last straw came when Denis Bardon borrowed Leon's tractor. Not only did he not pay for the use of the tractor, but he presented Leon with a bill for a new battery cable. Over the next few years, the Bardon couple took advantage of various other neighbours. When they sold out, the yard sale even included a ladder that had been borrowed from a neighbour, and unopened presents that they had received as wedding gifts from the community.

Besides family and community, other forms of assistance came from government. While soldiers had very limited income, the Mackenzie King Government established various programs to accommodate returning soldiers. In particular, the Veterans' Land Act (VLA) provided grants and low interest loans to discharged soldiers for the purchase of land and equipment. The Act also gave veterans priority in buying machinery at a time when there was a limited supply of new equipment. However, those who had not signed up for overseas duty could only access the provisions for loans on the purchase of equipment, and not for buying land. Another value of the VLA was that the farmers with loans were 
required to keep account books to show that the operation was viable. Thus, they learned the accounting side of business operations.

In the case of Leon and Dorothy, it is difficult to decipher how the VLA loan was used in the early account books: the loans are not shown as income and the specific purchases are not identified. The first "VLA" entry is an expenditure on 30 July 1947 showing $\$ 345.73$ as Soldier Settlement payment on machinery and another on 29 October 1947 showing a VLA payment of $\$ 900.00$, then there is a 1 October 1948 expenditure entry of $\$ 500.00$ shown as Solder's Settlement. It is possible that some of these were grants rather than loans. Based on the payments that were entered into the account books for 1947 to 1957 , we have estimated a loan of $\$ 1,500$ that was paid off with a final payment of $\$ 349.00$ on 4 November $1957 .{ }^{16}$

Family Allowance was another form of government support. This allowance started in 1945 at $\$ 5.00$ per child per month. In 1959 the total payments to Dorothy and Leon amounted to $\$ 616$ (or \$5,300 in 2018 dollars). This represents $14 \%$ of the 1959 total income. As a further comparison point, the municipal taxes in 1959 were $\$ 543.30$, having increased from $\$ 186.50$ in 1949.

\section{Farm and household production: 1945-59}

As with other farms in the district, Leon and Dorothy were producing much of the food that they needed:

At first, we bought a minimum of things from stores, making our own bread, producing our own meat, milk, butter, eggs, potatoes, and most vegetables. Most of the meat that we consumed was from our own produce. We also produced most of our own vegetables, and we canned beans, peas, corn, cucumber pickles, along with raspberries and saskatoons. Slowly, a few cans made their way onto the shopping lists.

There were three meals a day, plus lunch at 4:00. Both dinner and supper were big meals, with meat, potatoes and vegetables. On Fridays we had fish or pancakes. There was jam and bread for breakfast, dinner and lunch, with other deserts like pastry at supper, or fruit that we had canned.

I did my own sewing, not jeans but some dresses, and much repairing and mending.

Mixed farming was important to self-sufficiency, with chickens, milk cows, cattle, and pigs. The garden played a crucial role, with all able bodies helping with planting, weeding and harvesting. The garden produced potatoes, carrots, beans, peas, corn, tomatoes, beets, cabbage, cucumber, lettuce, radish, onions, turnip, cauliflower and kohlrabi. Leon had made a cold frame out of old storm windows, for

\footnotetext{
${ }^{16}$ This estimate was calculated by Fred Beaujot based on the following information: The first payment on the VLA loan is shown on 26 November 1947, for $\$ 22.41$. The account books for 1949-59 show a 1949 payment to the VLA for $\$ 300.00$, then payments of $\$ 176.85$ for each of 1950 to 1957 . This loan would have been paid off with a "final loan payment of $\$ 349.00 "$ on 4 November 1957.
} 
Dorothy to get an early start with the lettuce and radishes. There were also raspberries, gooseberries, rhubarb, crabapples, horse radish, red and black currants, and asparagus. From the yard, Dorothy also picked young dandelions for salad, and lamb's quarters (also called pig weed) ${ }^{17}$ that she cooked as spinach. For a few years, Leon made wine with fruit. The whole family would go out together to pick wild fruit, especially saskatoons, chokecherries and sometimes raspberries and strawberries. These were then preserved as fruit or jam. We all remember dipping toast into chokecherry syrup at breakfast, sometimes adding cream, what a treat!

The yard at Harry Adams place, purchased in 1968, was an ideal place for a garden, with good loam soil, surrounded by trees. There was a "fifty-year-old" asparagus patch, raspberries as well as red and black currants. By the mid-1970s, Pat recalls that he and Adelin would be picking "as much as five gallons of raspberries every other day". They were also responsible for mowing the yard with a push mower. Pat recalls that "there was no end of work".

Dorothy adds:

I liked to garden, to watch things grow and produce. On the farm, I didn't have many flowers, though some flowers reproduced themselves and I worked the soil around them, but there were not so many types of flowers back then. People weren't so crazy about flowers in those days.

I never liked milking cows but did it because it had to be done. At the Mullie farm we would be selling as much as three or four five-gallon containers of cream per week. It was nice to have the cream cheque, so we continued doing this on our farm, but Leon did most of the work. He also did the separating with our cream separator which was run with the 32-volt electricity system. Both the electricity generator and the cream separator were in the basement, so that was convenient. I mostly cleaned the disks of the cream separator when doing dishes every night. I milked when Leon was too busy in the field or had to go to town.

Leon would get together with a neighbour to hunt wild ducks and sometimes deer:

With our neighbour Clarence Blackstock, we once came home from the fields with 20 to 25 ducks each, in the back of our trucks. Of course, that was only part of the job, since they then had to be cleaned and canned.

But I was not fond of hunting for large animals. Once when I went hunting with friends in the Moose Mountain, we had a license to take a moose, but we shot an elk instead. Not only did we have to pay a fine, but we could not take the meat home. There were accidents and I didn't really like hunting for deer or moose.

\footnotetext{
${ }^{17}$ Doreen found the lamb's quarters so good that she continues to collect and prepare them in this way. These grow in worked fertile soil on the edge of a garden or field. Doreen and her mother were always careful to pick them before an area was sprayed for weeds.
} 
Another time, when it was not the hunting season, a large bull moose came out of the valley to the north of the farm. I came home by tractor and got my gun, managing only to wound the animal as it slipped back into the valley. My neighbour George Brûlé heard the gun shots from a mile away and came out with his own gun, managing to kill off the animal as it emerged on his side of the valley. No sooner had I returned home empty handed that I received a phone call from George on our party line, saying that he needed help with a calf that was being born. The story about the calf was just a deception. He had wanted help to slaughter the big moose! We eventually shared the kill with other neighbours who could be trusted with the illegal meat.

The farm was well suited for cattle. There was good pasture land, with a valley and creek running most of the length of the property. This pasture came close to the farm site which had a well and dugout for water. The barn was a low shed, with no loft and no windows, and of course no automatic devices to bring in the feed and remove the excrement! Once the 32-volt electrical system was installed, three lights were put in the barn, and 'it felt like heaven in there, compared to the dark hell-hole that we had known' says Dorothy. Leon continues:

In 1947 a big snow storm completely covered the barn. I had to take animals out through a narrow door at the back to get watered. It took a couple of days to shovel the snow away from front door. We had to carry a calf to the house, to revive it and watch over its first days of life.

We started with four or five cows, from our parents, but we never had more than about 20. During the winter, they were all kept in the barn at night, and even during the day when the weather was particularly cold, along with a team of horses. In those days, no one tried to have farm animals outside through the prairie winter.

With the warmth from the cattle and horses, the barn also provided shelter for hens, cats and dogs. There was a firm view that cats and dogs did not belong in the house, even on cold winter nights. Leon remembered the following exception:

Our neighbour Clarence Blackstock had a dog that was very frightened of lightning storms. They would let him in the house when there was a storm. Once, a storm occurred while the neighbours were away, and the dog came the quarter mile to our place, scratching frantically at the door. I got quite a surprise when I opened the door and the dog swooshed in. But he was well trained and just laid down by the door for the duration of the storm.

Besides the barn, the farm had a new chicken house, which was a selling point for the farm. This shed was eventually used for pigs. An electric fence was installed so that the pigs could go out. The electricity for the fence involved a battery which was charged by the car or tractor. Leon adds: "After the pigs began killing each other, we went out of pigs and used it again for chickens."

This chicken shed is well remembered for its attic, filled with flax straw, making an excellent location for litters of kittens. The space between the straw and roof was also accessible to small children, who enjoyed having a space of their own, that adults could not access. It was important to retrieve and tame (domesticate) the newly born kittens before their claws became too sharp. 
Income sources: grain, livestock, custom work, cream, eggs

Eggs and poultry were entered into the income accounts in 1946-49 (see Table 6.2). The year 1949 is the last to include a separate account book column for poultry, showing $\$ 85.00$ as the value of the hens and roosters butchered for home use. ${ }^{18}$ While eggs and poultry represented a small share of farm income, it was important to home consumption, at low cost.

Chickens were purchased from a hatchery in Brandon and delivered via the train that arrived in Langbank at midnight. The very hungry chicks would typically make the final leg of the journey by horse and sleigh, not being fed until they had arrived on the farm. At first the newborn chicks would be cared for in the house because the barn was too cold. As they got a little older, they would be in the barn or chicken house, and in the summer, they would be out in the yard during the day.

In the fall, a day would be dedicated to butchering and preserving the chickens. The 5 or 6 month old chickens were slaughtered then brought into the house for plucking, cleaning and preserving. The feathers were taken off by first submerging in hot water, then the remaining hair was burnt off over a flame. Then the guts and innards were removed, and the meat would then be cooked and preserved in jars or bagged and frozen. From a young age, children could help with various parts of these tasks, especially the removal of the last pin feathers. For the next day or two, the house would smell of a butchery, with the hair-burning adding a less nauseous smell.

The income inventory includes entries for cream in 1947-50 and 1959-62. For instance, 1959 shows $\$ 225.18$ for cream $(\$ 1,938$ in 2018 dollars). The production and marketing of cream was labour intensive. The milk cows had to be kept in the barn during winter, where they were fed, the manure was removed by pitchfork, and fresh straw was brought in. The cattle were taken out for water. The milk cows were milked by hand, which would take about 15 minutes per cow.

The milk was brought to the basement where the cream separator was located. The cream was separated by being flowed through spinning discs into separate containers for the skim milk and cream. Before electricity, the discs were turned by a crank. Young children could be involved in turning the crank. This was a tedious job, with a bell set to ring if the cranking was being done at insufficient speed. Another big job was the daily cleaning of the three containers (unskimmed milk, skim milk and cream) and the 15 or 21 discs. The final task was to bring some of the skim milk to the calves that had to be taught how to drink from a pail rather than directly from the cow.

The production of cream was always a small operation, though milk, cream and butter were also important for home consumption. Eventually, margarine was a cheaper alternative, though many considered it second rate. One Christmas, when the Driscoll family, Leon's sister, was visiting, Dorothy

\footnotetext{
18 There is a similar entry of $\$ 28.00$ for poultry in 1958 . This again was for home use. In other years, the value of poultry and eggs for home use was not recorded.
} 
and Leon decided to have corn-on -the-cob which they had frozen from the fall garden harvest. This was a luxury since corn-on-the-cob took much room in the freezer. While setting out the meal, Dorothy suddenly realized that they had not purchased butter for the occasion. They knew that their brother-inlaw Joe was averse to margarine. At that time, it was only legal to sell white margarine, with yellow powder in a pouch that could be mixed in. Having no alternative, Dorothy and Leon mixed the yellow powder and a little salt into the white margarine. Only at the end of the meal was the deception revealed, with the delight of finding out that Joe had not realized that it was not butter.

As various farmers had their own equipment, Leon's income from custom work declined, from \$893.19 in 1949 to \$146.00 in 1951. The relative share of income from custom work was at its highest when Leon had one of the first weed sprayers in the district, but there was other work on an occasional basis, such as when a farmer needed help in finishing the combining with the approaching winter conditions.

The next category was livestock where the income increased from $\$ 1,098.12$ in 1949 to $\$ 2,283.96$ in 1951 , but then declined to $\$ 628.00$ in 1953 , remaining at this level for the remainder of the decade. The advent of hoof and mouth disease in the early 1950s undermined the value of cattle. Leon had poor luck with pigs, finding over successive days that one or the other had died, probably from being attacked in a common pen. Cattle were still raised for home use, with butchering occurring in the farm yard and preserving in the Whitewood locker plant. The labour associated with livestock included producing hay, maintaining fences, and feeding the cattle in winter. In the coldest part of the winter, the cattle and horses were kept in the barn, which required twice daily feeding and watering, with daily taking out the manure and adding new straw. The cow often needed help when a calf was being born. It was important to read the signs of an oncoming delivery and to know what to do, sometimes calling a neighbour to help.

The production and storage of hay is another important task associated with livestock. Typically grown in areas less suitable for grain production, the grass needed to be cut, raked into rows, collected on a rack, then stacked close to the barn. This would occur in the later part of the summer, before the grain was ready for harvest. Gathering the hay would be difficult for one person to do on their own. If children were not old enough, older boys from the area would be hired to help.

With the decline in poultry, cream, livestock and custom work, grain production increasingly became dominant as the main source of income over the period 1953-59 (Table 6.2).

There was considerable labour involved in grain production, but this was more mechanized. Besides seeding and harvest, weeds had to be controlled by cultivating the land and spraying the field after the grain had started to grow. Seed grain and fertilizer needed to be purchased and the grain needed to be brought to market. The income from grain represented $77.5 \%$ of farm income in 1952, rising to $91.2 \%$ in 1959. However, here again there was considerable uncertainty due to weather conditions: 1953-55 were wet years with excessive rainfall drowning the crops and preventing harvest, and in 1958 a hail storm destroyed much of the crop. 
Following in the footsteps of his father-in-law, Paul Mullie, the Registered Seed Grower, Leon produced seed grain, mostly barley, in the 1950s. This required a cleaning mill that used sieves and a blower to remove the weeds and chaff. Purchased in 1951, the Viking Fanning Mill ${ }^{19}$ was run by a small motor powered by the 32-volt electrical system that they had purchased in 1948 . The cleaning was done in a five-compartment granary that Albert Beaujot had built, as the first building that Leon and Dorothy added to the farmyard. ${ }^{20}$ The granary was unheated, but the separate compartments, with a capacity of some 800 bushels each, were ideal for keeping various grains separate and close at hand. There was a middle area along the length of the building, some 8 feet wide, where the cleaning mill was located. The income summary for 1952 shows 15 entries of seed barley and oats sold in amounts between 10 and 150 bushels to individual neighbours. This was sold at $\$ 1.50$ per bushel when the market rate was $\$ 1.07$.

The marketing of wheat, barley and oats was subject to permits by the Canadian Wheat Board. As of 1943 , it was against the law to sell these grains outside of the permit system established by the Wheat Board. Farmers were issued Permit Books where the acreage in various crops was entered, and permits were issued based on these acreages. Farmers would receive initial payments when the grains were delivered to the grain elevator agent, and a final payment when the Board had sold a given year's delivery. Initially, part of the rationale for the system was to keep grain prices low to support the war effort. Another rationale was to take the risks out of the market so that farmers would have the same price regardless of the timing of their sales.

While there were benefits to farmers, the Wheat Board also presented limitations as farmers were not allowed to sell wheat, barley and oats outside of the Permit Book system. Even grain brought to a mill to make flour for their own consumption was to be entered. There was also the concern that the farmers were supporting the bureaucracy of the Wheat Board. Especially when comparing prices to those in the United States, many felt that this system was undermining the prices that farmers could get on the open market. This "single desk" system of the Wheat Board was abolished in 2012 when the Board became a voluntary marketing organization. Reflecting on these questions around the time of his $90^{\text {th }}$ Birthday in 2009, Leon observed:

In my view, the Wheat Board has outlived its utility. When it was first formed, the Wheat Board provided stable prices and markets for farmers, but its main objective was to control the price of wheat for export to the armies in Europe. With computers and the internet, farmers are now able to keep track of prices and many would prefer to have more control over the markets for their products.

Another problem that Western farmers faced in marketing grain was the railroad monopoly over transportation. This undermined the price they could get for the grain they produced, especially in comparison to the prices that U.S. farmers could get with more marketing alternatives.

\footnotetext{
19 This Viking Fanning Mill was purchased in 1951 for $\$ 128$, and it was sold to the Joan of Arc Home in 1960 for $\$ 90$.

${ }^{20}$ The building was about 24 feet wide and 28 feet long. Each of the four bins were about 8 by 14 feet, with the "hallway" in the middle about 8 feet wide along the length of the building (estimates thanks to Norbert Beaujot).
} 


\section{Equipment and discovering how to operate}

Describing the first equipment purchased after they were no longer using horses, Leon observes: We bought a sprayer, tractor, swather, cultivator, and one-way drill. In 1951 we added an Oliver pull-type combine. The 6 feet drill was one of the first ones of the district. It had the advantage of cultivating the soil in the same operation as sowing and fertilizing. Harrows would be used after seeding, to level the land, and after cultivating, to kill some remaining weeds. The cultivator was about 10 feet and the swather 15 feet, with an extension that could be removed for a heavy crop. The seeding drill was later replaced by a disker that was about 15 to 18 feet, but it used about the same amount of energy as the 6 foot one-way drill.

In Food 5.0: How we feed the future, Robert Saik (2019) proposes five stages of increasing efficiency of food production: muscle, machine, chemistry, genetic engineering and convergence (including precision agriculture and artificial intelligence). Over the first few years of farming, Leon and Dorothy went through the first three of these stages: mechanizing the work that was previously done by horses and using chemicals for fertilizer and weed control. Of course, there was still much hard work, using their muscle power and eventually that of their children.

Pat Beaujot observes that the one-way drill (or seeder) was an important innovation for the northern plains at that time. Prior to this, most seeders only placed the seed in narrow rows and packed the soil around the seeds. The operation did not do any weed control as no tillage was done between the rows. Farmers needed to first make a pass with some type of complete coverage tillage equipment to kill weeds. This previous seeding equipment had been developed in Europe where rain was plentiful and there was less concern about drying out the land with a separate tillage operation, and the resulting insufficient moisture for germination. In effect, the one-way disc seeder was a step in the direction of reduced tillage, preserving moisture while saving fuel, labour, time and wear and tear on tractors and equipment.

By 1951, they had the full range of equipment for sowing, controlling weeds and harvesting. With the short growing season, and the importance of timeliness in these operations, it was important not to depend on other people for the crucial tasks of planting, spraying and harvest. Leon would say: "wheat has to be in the ground by the first week of June." The timing of seeding needed to be as late as possible to let the weeds germinate in the spring then till them up and quickly seed so the crop would get a head start on the weeds. With better weed control, the goal for wheat has moved to 15 May. ${ }^{21}$ At harvest, the timing of swathing and combining are crucial to ensure maximum maturity and taking off the crop before rains undermine the quality of the grains.

Leon: Encouraged by Paul Mullie, we purchased a 1948 Equipment Co-op weed sprayer. We eventually used it to spray the whole country with 2-4D. The sprayer was put on the Oliver 70 tractor. The equipment included a 40-gallon flat fuel tank carried by the tractor, a boom, hose, and nozzles for the

\footnotetext{
${ }^{21}$ Evaluation and advice obtained in 2019 from agronomist Pat Beaujot.
} 
front of the tractor, and instructions for setting it up. With 40 gallons of 2-4D, I managed to spray for ourselves and about ten other neighbours. Paul Mullie was so happy to see this system that would control the weeds. It sure was an improvement over hiring young people to walk every foot of the field to pick the weeds. Paul Mullie would be even happier to see the clean crops today, with sprays even for wild oats. The only spray that we had in 1948 was 2-4D for thistles, dandelion and broad leaf weeds.

The first time we filled it with well water, the chemical curdled, blocking the nozzles. Each of the nozzles had to be cleaned by blowing into them by mouth, so that we could try again with soft water. Only later did we realize how dangerous this had been. Needless to say, there were no masks, protective clothing or special glasses to wear when operating the sprayer. Of course there was no enclosing cab on the tractor and thus the driver got much spray in his face.

Dorothy: We also sprayed house with DDT. Earlier my mother had used Formalin in a dish on the table, leaving bread crumbs around to attract the flies. We also mixed this into grain to prevent smut. We did this without masks. We knew we should not drink the Formalin, but we did not realize how poisonous it was. Leon observes that this may have killed other infections as they have maintained good health into their 90s.

Leon continues: In 1951, we had our Cockshut tractor and Oliver combine, also using them to do custom combining for others. Raymond had two combines but could not finish the jobs that he had scheduled, so Leon finished the combining on the Brûlé and Cottin farms in cold November weather. George Brûlé was especially anxious to get his crop combined because the cows were getting into the fields. The frozen cow turds were like stones, and the concave would get all gummed up. This prevented the threshing to work properly as the grain was going out the back instead of into the hopper. We had to take everything apart to get the crap out of there. At night, we would take it in the house to thaw out (the concave, not the whole combine), and to be able to continue the combining the next morning, in the -10 Fahrenheit (-25 Celsius) temperatures.

At the Mitchel Cottin farm, they had been trying to combine but they were picking up so much wet snow and ice along with the grain that we had to pile it outside so as not to damage the dry grain in the granary. When we harvested under colder conditions, the snow was so cold that it would blow out the combine, leaving the dry grain. But it was so cold on the tractor that we had to take a shot of whiskey at each full hopper, just to keep going. At the same time, it was challenging and fun to be out there with friends and neighbours. There were always sumptuous meals once the day's work was done.

We had also discovered that combining frozen was better than wet. It was important to learn how to combine under the various fall weather conditions in Saskatchewan. When harvest was by threshing sheaves, the unthreshed harvest was less vulnerable to wet conditions as the sheaves were stooked in a tent shape that would shed the rain, and they could be collected in a stack while waiting for the threshing machine to become available. Some had argued that the swathing/combining operation posed problems when conditions were difficult, and thus it was important to learn how to operate these more efficient machines under less than ideal harvest conditions. Depending on the amount of dew and 
sunshine, we found that the swaths of grain lying on top of the stubble dried rather quickly, even late into the fall.

Our second combine was a Minneapolis purchased in 1960. This combine had higher capacity, but still presented the problem of getting 'bunged up' when a large swath of grain accidentally overwhelmed the capacity of the concave. This can especially occur at night when it is hard to see the amount of swath going up into the combine. It helps to know the field, including where the crop is heavier. Nonetheless, accidents will invariably occur. Now they have automatic sensing devices that send out red flashing signals and even stop the machine before the problem occurs.

Once when the combine had been jammed, in the middle of the night, it was brought into the yard so that Leon and Dorothy could be better equipped to work together at removing the concave and clearing out the combine. Since this was the first time this clogging had occurred on this combine, they needed first to figure out how to remove the concave. It seemed simple, just a matter of removing a few bolts and prying the concave off with hammer and punch. Dorothy was doing the hammering, as Leon guided the punch to the proper spot. As she was hitting harder and harder, and as they tried various ways of removing the concave, this took hours of precious time. All the way through, Dorothy felt that there must be an obstructing rod which first needed to be removed. They finally gave up after much frustration, only to find in the proper daylight the next morning that the concave came out easily, once the obstructing rod had been removed. The method of unclogging that combine was never forgotten, and carefully explained to the next buyer of the implement.

\section{Transportation, heat, electricity, water and sewage}

For their July 1945 honeymoon trip to the Regina Exhibition, Leon and Dorothy had a used Model A Ford that they had purchased from Dorothy's brother Raymond Mullie. This car was also used for the April 1946 trip to Whitewood at the birth of their first child. However, the car could only be used when the roads were not blocked by snow or impassable because of wet conditions. They took the train from Inchkeith to Regina to sign Leon's Discharge Certificate from the Canadian Army on 29 January 1946. The expenditure statements show $\$ 12.70$ for two return train tickets to Regina on 22 January 1947. Judging from the places of purchase as indicated in the account books, most trips were to the Saint Hubert Co-op and the Whitewood Co-op, with also some trips to Kipling. Other things were purchased by mail from the Eaton's catalogue.

During winter conditions, or when the roads were too wet for cars, travel was by horse and sleigh or horse and wagon. Horses were especially used for winter travel to church at Saint Hubert, which was obligatory, regardless of the road conditions. Horse and sleigh were also used for winter transport to community gatherings or to visit neighbours. At Saint Hubert, and at other towns, there was a stable where horses could be kept and fed before the return trip. Even if the roads were passable, it was difficult to start cars in cold weather. One method of warming up the motor was to place embers from the kitchen fire under the front end of the car. 
Especially with temperatures that would routinely go down to minus 40 degrees (where it is the same temperature on the Celsius and Fahrenheit scales), this difficulty of starting motorized vehicles persisted even after block heaters were invented. If there were too many visitors to bring electricity to each car, the driver would go out to start the car every two-to-four hours to ensure that it did not freeze solid. In about 1973, when his university-age children were coming home for Christmas, Leon decided to clear the snow off the dugout with tractor and blade to make a skating rink. While the ice was frozen solid, he did not realize that the grass at the edge of the dugout would weaken the ice. Sure enough, the tractor got caught in the ice. Since it could not stay there, he called a neighbour to come with his tractor to pull the tractor out of the ice. The neighbour was quite willing, but he first had to plug his tractor in so that it would start. After several attempts, they realized that they would need two tractors to do the job. A second neighbour was called. With all children home by now, it was well after midnight before all tractors and neighbours could be retired for the night.

The difficulties of travel were the main reason for delaying Roderic's school attendance until he was seven, in 1953. That way, there would be only one year during which Roderic would be the only one at school, with Norbert Beaujot and Warren Blackstock starting the next year. Although they lived closer to the school, the parents of another neighbour boy, Roger Cook, also delayed his entry into school, so that there would be two children in Grade I in 1953. When his eldest son was in Grade 1, Leon drove to school when the roads were passable, otherwise doing the 3.5-mile trip twice a day with horses. In spring conditions with wet roads, Leon would do the trip on horse-back. In 1954, with Norbert and Warren also at school, Leon and their neighbour Clarence Blackstock would take turns for the school trips.

During the wet years of the mid-1950s, the dirt roads were often impassable by car. Sylvain Dumonceaux remembers a 1953 trip to get a wedding cake for his sister Solange in Whitewood when the No. 9 Highway was impassable to the north. They had to go by Langbank, Kipling and Broadview, adding 50 miles to what would have been a 15-mile trip to Whitewood. It was not until 1960 that allweather roads were built with a gravel surface, as the one-room schools were closed, and the children were bussed to Langbank. Leon and Dorothy sold their last two horses in 1961.

In 1949, Leon and Dorothy had purchased, a 1948 Dodge car with a millage of 15,950 for $\$ 2,050$ (\$22,400 in 2018 dollars). While it was expensive, the 1948 Dodge served for many years, with more and more children crowded into the back seat. It was not until 1961 that another car was purchased: a 1957 Ford Station Wagon for $\$ 1,500$ (\$12,600 in 2018 Dollars). When Honory was able to stand, he had a spot with very good visibility on the left side of his Dad. It was from this vantage point that Honory was looking intently at the white oil containers as we approached Regina, suddenly using his limited vocabulary and calling out: "bum paper!"

\section{Heat and electricity}

When they were first married, the house was heated through wood and coal. Leon and Dorothy continue: The Elkington's had left an excellent kitchen stove, which served us for many years. This stove 
used wood and coal, with a hot water tank on one end. In the fall of 1947, we also bought a night stove (Warm Morning Heater) for the living room. The night stove also burned wood and coal, and it had an automatic damper that would shut off as the fire went down. In the morning, the coal embers were still hot so that wood or coal could be added, and the flu opened to create more heat. This was a good design and that is why it was called a Warm Morning Heater. It would keep the house from freezing during the whole night even in the dead of winter. On cold nights, we needed to get up early to get house heated again. The oven of the kitchen stove was very sturdy, and as many as three children could sit on it warming themselves.

Leona continues: I remember Mom baking cakes on top of the wood stove. When we had the baby chicks in the house for a few weeks in the spring and one would get sick and died, she tossed it into the wood stove to burn (not a pleasant memory). A more pleasant memory was Doreen, Adelin and I warming ourselves, sitting comfortably on the oven door. In the late 1950s, an electric stove was purchased and subsequently converted to propane.

Dorothy: A three-burner gas stove was one of our smartest purchases. We used it for all of our canning, making jam, much of the cooking, and it could even be used to bake cakes at a very low heat. It generated less heat in house than a stove, and it was so much easier to use. There was also a lack of wood on our farm, and this was a good alternative to a regular wood stove.

Some farms at this time collected energy from a windmill that was used to charge batteries. This wind system was not efficient. The batteries could not reserve enough electricity and they would deplete too quickly. It was really only good for lights and radio. It was very nice to have lights that you could just switch on, but two to three days without wind would completely discharge the batteries. It was only with a good wind that you could run an iron or washing machine. There was a windmill on the Mullie farm, but we did not have this on our own farm. We did use wind power to directly pump water from the well, especially for the animals.

Another system involved renting batteries that were charged by someone who had a windmill. Emile Gatin had devised an exchange system with used car batteries. He would rent out the batteries and recharge them, often making the exchange after church on Sundays where his clients had gathered. During the winter, he would take the batteries that were not in use into the house so that they would stay charged and not freeze. We used his batteries to provide one light over the sewing machine, it was so nice to have this light.

Whenever Leon and Dorothy discussed early purchases, two particularly 'smart purchases' were invariably mentioned: a sprayer to control weeds in the fields and a 32-volt electrical system. Both were purchased in 1948, one for the farm, and the other mostly for the house.

The 32-volt electrical system was purchased from a dairy farmer in Manitoba, who was living closer to the city, with electricity coming sooner into the district. The farmer received four replies to his ad in the Western Producer, but only one came with a cheque. Leon wanted to write asking for further 
information, but Dorothy said, "let's just send the cheque because it is just what we want". Everything was going by Christmas, even two lights in the old barn. The cost of power plant, as indicated in the account books, installed and wired was $\$ 395.75$. Dorothy continues: "The farmer in Manitoba had sent the power plant plus all his 32-volt appliances, so now we were totally electric, with even a toaster and coffee maker."

Leon did all the wiring of the house and barn. He observes that it was a "pretty rough job", but it was safe and sound. Leon continues: When we got electricity from Saskatchewan Power, our cousin Armand Gatin, who was an electrician, replaced the meter boxes and switches, but the wiring that I put in was still being used to carry electricity in the house until the house itself was abandoned many years later, in 1989.

There were 16 batteries, each 2.5 feet tall and a foot square, with clear glass. Each had a green and red float that would indicate the level of the charge. The batteries were in the basement. They were charged by a motor running on distillate fuel (between coal oil and gas). A proper exhaust system was installed, going out of the basement. The motor had to be started every morning to make toast. But it was such a change; before that there were only lamps, and these had to be carried wherever one went; it was amazing to have all that light. Dorothy would always say that "this was the best thing we ever bought".

Various experiments were attempted with this new-found source of energy. Some were successful from the beginning, others required further adaptation. Leon tried to install a motor on what had been a footrun butter churn, with a fly wheel. The motor ran the churn too fast, and the lid flew off, splashing butter milk all over the ceiling. Leon continues: I installed another motor to run a machine for cleaning the weeds and chaff out of seed grain, instead of powering this machine by a hand lever. This was very successful because seed grain got a good price, but it was difficult to meet the standards of low weed content. By 1953, I was using a motor to clean barley, oats and wheat for other farmers, selling the weeds and chaff to the Joan of Arc Nursing Home for chicken-feed.

We also tried to use an electric fence in the farm yard. This also required experimenting because the cattle had to learn that the fence was electric before they would stay clear. In our first attempt with an electric fence for cattle, the bull went right through not realizing that it was electric.

Dorothy continues, regarding other uses of electricity: We had a separate system for radio, with a big battery that needed to be replaced after a year. The telephone was also run with two big batteries. In 1954 Saskatchewan Power brought electricity to each of the farms that paid the $\$ 480.00$ fee. In 1956 , we bought a freezer, which made such a difference to preserving food. Before that, we had to can things in jars. Meat was also kept in the Whitewood locker plant. During winter, frozen meat could be kept on the farm. This method of storage could be used in the early spring, by pushing a package of meat, tied to a stick, deep into the grain of a granary. 
Leon and Dorothy: When we extended the house in 1952, we got an oil floor furnace right away. The furnace had a floor grill, in the passage between the kitchen and the family room. It was one of the early furnaces of the district. The grill on the furnace was dangerous, but it could also be used to boil water and treat a cold by breathing in steam from a pot of water on the furnace. The children would stand over grill, especially when it was turned up as we returned from being away. The children seem to each have an accident with the floor furnace as they were growing up, but Norbert's scar was the largest, on the butt. The floor furnace was still there when Pat was young, and he too has a scar to prove the danger. Later a furnace with ducts was installed in the basement.

\section{Water and sewage}

Initially, the house was not connected for water and sewage. All water had to be carried into the house by hand, then heated on the stove for washing dishes, clothes and bathing. Laundry was a full-day's job, with clothes dried outside. Bathing was once per week, on Saturday, with the smallest children going first and water being added as the larger ones had their turn. Adelin remembers snow melting in pails on the stove for bathing. The three girls bathed together, with Adelin getting the shallow end because she was the youngest.

The toilet pail was emptied in the bush. There was also an out-house in the bush behind the house, but the boys could go anywhere in the yard. During the summer, it was a nighttime ritual for the boys to be sent outside before going to bed. Once there were neighbouring boys having a sleep-over, and Dorothy said, "OK boys, time to go outside." The visitors were puzzled, thinking that they were being sent outside as a punishment. Crying, they asked their hosts: "What did we do?"

In 1957, a water system was installed ${ }^{22}$, bringing water from the cistern to the kitchen and bathroom. The well water was still carried in for cooking and drinking. When writing this account on water and sewage, a detailed discussion took place across the Beaujot children. Some thought that a septic tank had been installed at the same time as the water system, while others claimed there had been no sewage system on the north farm. Honory's memory seems the most reliable: "The toilet pail, when over flowing, was carried out and dumped between the house and the dugout in the barn yard." Pat, who now owns this property, says he never found a septic tank in the ground where the yard had been.

Doreen recalls that there was outside drainage from the bathtub. She remembers pulling the plug then running outside to watch the water drain out the side of the house: I probably needed another bath after playing in the dirty water.

Adelin recalls crumpling the paper from the Eaton's catalogue before using it on the toilet. She continues: My introduction to toilet paper was when we were visiting Uncle Joe and Aunt Flora. They

\footnotetext{
22 There was uncertainty regarding the date of the water system. However, the account books show an expense of $\$ 130$ for a pressure system in June 1957. This pressure system must have been for delivering water from the cistern to the kitchen and bathroom.
} 
had toilet paper in their outhouse and Bernice said we were only allowed to use four squares. In later years, there must have been an abundance of toilet paper as Bernice taught us three girls how to make beautiful paper flowers with different colours of toilet paper. Doreen thinks it was Mom's hired help, Dianne Jordens, that taught the girls how to make flowers out of tissue paper. Leona remembers: when toilet paper was first bought, it was for Grandpa only. We were not allowed to use it. Christmas was a treat, not only because it brought sweet treats and goodies to eat, but also the soft wrapping paper around the individual mandarin oranges was a treat for the tush (behind).

After the house was moved in 1962, a septic tank was installed for the dirty water from the kitchen, bathroom and toilet. With the limited supply of well water, Dorothy would say to visitors: "If it is brown, flush it down, if it is yellow, let it mellow."

On the south farm, there was once again a cistern in the basement, collecting rain water from the roof. The rain water was soft and especially good for bathing, laundry and washing dishes. ${ }^{23}$ There was a separate system for well water, used for drinking, cooking and flushing the toilet. ${ }^{24}$ Leona noted in her log book of March 1973 that while at home from university with her friend Linda, Dad asked them, along with Pat and Fred, to clean out the cistern. Jeanette was apparently too busy gathering eggs from the chicken coop. Pat also has vivid memories of climbing into the cistern to "clean the mud off the floor along with a few mice carcasses".

Especially as the family grew, the well and cistern water were not always reliable. In dry years, the well water, used for the house and livestock, would run out. Pat remembers hearing the pump running continuously in the basement. It would have to be primed to get the water system going again. Water was very precious, and it was important not to waste it. The cistern, connected to everything but the drinking water tap and the toilet, would usually run out before spring and then the well was used for all the water. Pat continues: You could also hear the little cistern pump when it lost prime. Bad news because it was hard water until the rains came. At some point, a water softener was installed.

\section{Language and community}

In the Mullie and Beaujot households of origin, communication was always in French. While catechism was taught in French, schooling was in English, even at the Sainte Jeanne d'Arc convent which operated as a school in 1921-24. Young people spoke French at home, but in the community, they often used English among themselves in order to communicate with the non-French friends and neighbours. Until the departure of the Fils de Marie Immaculée (F.M.I) priests and brothers in 1961, the services at St.

\footnotetext{
${ }^{23}$ Norbert recalls in incident when returning home from university for a weekend, where he offended his mother by insufficiently appreciating the value of the soft water for bathing. As this account was being written, Norbert sent a belated apology.

${ }^{24}$ Honory recalls that, soon after the house was moved, the well, located between the house and the creek, was connected via a plastic pipeline to the house and barn for drinking water and toilet flushing. Honory continues: a true luxury, my first pipeline.
} 
Hubert Catholic Church were in French (and Latin of course), with parts of the service repeated in English.

Dorothy learned to read and write French with her mother, and she took French as an optional subject in Grade 9. Leon also learned to read French with his mother and father. Leon says: "Mother had particularly nice writing and she could spell words properly in French."

The older generation also could communicate in English. Félicien had learned English working for the counts. He went to school very little, but enough to be taught by several slaps on the fingers that it was inappropriate to write with his left hand. He became ambidextrous and was able to write French. Even when he spoke English, he swore in French, with a favourite being "au nom de jot" instead of "au nom de Dieu".

When they lived on the Daily farm, the Beaujots had English neighbours, but Bertheline knew very little English. An incident is well remembered where she had wished she knew more English. Her young son Albert was always playing tricks on his mother, such as knocking on the door, then hiding. Trying to stop him from doing this, she once came to the door with a butcher knife, yelling "go to hell", only to find that it was her English neighbour Mr. Cross who had knocked. Both neighbour and host were very startled, and she could not explain why she had acted in such an uninviting fashion. She later learned some English when they lived at Handsworth, but she never liked to speak English and later stopped speaking English. Leon's Tante Modeste Payot was against speaking English, and she had a hard time with her niece Flora marrying Joe Driscoll, who was of Irish origin, but at least he was Catholic.

Julienne, Dorothy's mother, had learned several languages, including English, at school in Belgium. This served her well as she worked in the family grocery store in Sint Truiden (St. Trond), her home town, located close to the German and Dutch borders. From the time of their arrival in Canada, the Mullie family subscribed to English newspapers. Jessie Jordens, wife of Arthur, was English, and she was largely shunned by the priests at church. Knowing that her neighbour could not socialize in French after church, Julienne made a point of speaking with Mrs. Jordens in English. Paul Mullie learned to speak English, partly in having to communicate with his hired help. Swearing was always in French, with a favourite being "bon sang, bon sang" whenever things did not go according to plan.

Leon and Dorothy communicated with each other in English from the beginning, speaking French with their parents and others of the older generation. They spoke French to their children so that they could communicate with their grandparents. The school in Golden Plain was in English. With English coming home from school, the children were mixing up the languages rather seriously. They seemed to be developing a language of their own, sometimes even adding French endings to English verbs. In about 1958, when Leona was starting school, the parents decided to use English in communicating with their children, as they had been speaking in English to each other. French was less and less used in the household, though the children could still mouth a 'nous allons manger' to their grandfather. 
Leon and Dorothy continued to speak in French with some older neighbours, but eventually there was no one in Saint Hubert who was more at ease in French than in English. They did have occasion to speak French when visiting relatives in France and when French relatives came to Canada, but these occasions were rare. When Jocelyn Molton (son of Leon's first cousin Henriette née Sénéchaud) phoned in 2004 to find his Beaujot relatives in Canada, Leon surprised himself in being able to suddenly speak French.

\section{Community}

At the time of their marriage, the parish of Saint Hubert was their primary community. The Church was central to community gatherings, on Sundays and feast days. It was through the Church that people marked births, marriages, deaths and life stages of increasing participation and responsibility (First Communion, Confirmation). With its Co-op store, Praud's Garage, post office, school, parish hall, summer picnic and baseball team, Saint Hubert was the centre of much social and economic activity. Proximity, along with common religion and family connections, meant that much of social activity took place within the Saint Hubert community.

After their marriage, Leon continued to play hard ball, generally on second base, at St. Hubert. On one memorable occasion he caught a ball by throwing his cap at the fly passing overhead. On another occasion, an American team had come to play 'donkey baseball' as entertainment with the teams of various towns. Leon explains: as you hit the ball, the player had to jump on the donkey that had been trained to go around the bases. When I got my turn, the donkey went right around the bases, with the crowd cheering wildly, before the opposing players could retrieve the baseball. The second time that I was up, the donkey decided to buck me off between first and second base. From her place in the stands, Dorothy thinks she heard the crunch of the bones in her husband's neck and head. He was unconscious for a short while, but the sore neck lasted a lot longer, worsened over the years as he had to look behind at the implement being pulled by the tractor. In finishing this story, Leon notes that geo-positioning now allows farmers to look wherever they please, even with no hands on the steering wheel.

Besides Saint Hubert, there were other bases for community, especially Golden Plain School where gatherings took place especially for the Christmas concert and crocinole tournaments. Whitewood was important as a larger centre with more facilities, including a community hall where dances could be held. ${ }^{25}$ With the demise of Saint Hubert as a centre (even the church closed after its $90^{\text {th }}$ Anniversary celebrations in 1980), and the closing of local one-room schools, other towns gained prominence as a base for community, especially, Whitewood, Langbank, Kennedy and Kipling.

The telephone was another important means of connection, for both business and socializing. The party line brought further connections as neighbours could listen-in when they heard a call going to someone else on the same line. Once Leon had made a deal to sell grain at a certain price, but he had forgotten

\footnotetext{
25 The priests largely did not permit dances in the parish hall. With school trustees who attended the Langbank Community Bible Church, dances could mostly not be held at the Golden Plain School, but they did permit crocinole tournaments, as long as there was no gambling nor alcohol.
} 
the price when talking with another farmer. He called his neighbour Sylvain Dumonceaux to see if he had been listening in, and sure enough he knew the price that had been quoted.

\section{A second wind closer to Langbank}

As their oldest children were approaching their teenage years, and anticipating the birth of their eighth child, Leon and Dorothy entered a new phase of farm-family life that would substantially increase their agricultural production and bring their home onto all-weather roads with easier access to the centralized school in Langbank.

Their 1947 loan through the Veterans' Land Act had been paid off as of 1957, and there was now the opportunity to obtain a loan for additional land at low interest. As an army veteran who had not enlisted for overseas duty, Leon had only been eligible to use the VLA for the purchase of machinery. In the late 1950s, this limitation was removed, and Leon was able to access the VLA for loans on the purchase of both land and machinery. In Leon's words: When a new person took over the VLA office in Whitewood, he treated everyone equally. The previous person was himself a veteran who had enlisted and thus he had a prejudice in favour of those who had enlisted.

The account book for 1959 shows a VLA loan of \$1,200 for machinery. This was used to purchase a 1947 Model D John Deere tractor, a 1952 CCIL 12-foot disker and a 1952 Cockshut 10-foot H.D. Cultivator (see Table 6.3 at the end of Chapter 6). The statement on liabilities for 1960 shows a liability of $\$ 14,456$ for "land, buildings and improvements" at the end of the year. The VLA loan for land was used to purchase, from Camille Dumonceaux, the west half of 33-13-3 for \$8,000 in 1959 and the SE quarter of 33-13-3 for $\$ 4,000$ in $1960 .{ }^{26}$ The total farm acreage had increased from 320 acres in 1945-58, to 640 acres in 1959 and 800 acres ( 1 and $1 / 4$ sections) in 1960. In 1968, they would purchase the adjacent west half of 4-14-3 from Harry Adams ${ }^{27}$ for $\$ 21,750$, bringing the total size to 1120 acres ( 1 and $3 / 4$ sections) for the

\footnotetext{
${ }^{26}$ The homestead map for the Rural Municipality of Silverwood No. 123, shows section 33-13-3 as C.P.R. land as of 1901-05-02. This land was subsequently purchased by Samuel and Rosina Cook and inherited by his son Reginald and Mabel Cook (Langbank and District History Committee, 1984: 215-216). In about 1957, Camille Dumonceaux bought the farm from Reginald and Mabel Cook. Since Camille was not living there, Reg and Mabel would come to look at their previous land, especially in the spring when they could admire the lovely lilac hedge on both sides of the entrance to the farm yard. When Leon and Dorothy bought the property, they invited the Cook family to continue this tradition and to take home a bouquet of lilac flowers.

27 The homestead map for the Rural Municipality of Silverwood No. 123, shows the SW quarter of 4-14-3 as being the homestead of Joseph Cottin dated 1901-04-20, and the NW quarter of 4-14-3 as being the homestead of Samuel Cook dated 1907-03-02. Joseph Cottin had come to Saint Hubert from Lochieu, France, in 1893 to look after the horses of Count Alphonse de Seyssel (Memories of St. Hubert 1980: 77-81). "The first 40 acres of the homestead were broken with an ox and a horse with a lame leg." Hay was made in the marsh near Kipling, with a twelve-mile trip to haul it home during the winter. Joseph and Caroline built a two-to-three room log house with a sod roof, along with a sod stable for their few animals. They sold their homestead in 1903. The property would eventually be bought by Samuel Cook who now had the full west half of 4-14-3. Samuel and Rosina Cook sold the half section to Pearl Brown in about 1920. As a widow without children, Pearl Brown farmed very successfully for many years with the help of hired men. In 1947 she married Harry Adams, one of her hired men. After Pearl passed away in 1957, Harry Adams continued to farm, eventually marrying Olga (Gerry) McLennan in 1959. Harry and
} 
remainder of their farming years. Historical data for Saskatchewan indicate that the average farm holding increased from 473.0 acres in 1946, to 685.8 in 1961 and 845.2 acres in 1971 (Statistics Canada, 1983: M12-22, M23-33). Thus, the farm was smaller than the average Saskatchewan farm when there was only a half-section, but by 1960 it was above the average size. In 1971, their farm was a third larger than the average Saskatchewan farm.

In 1962, they moved their home onto the newly purchased land, two miles south and four miles east of its original location on what came to be called the north farm. With the disappearance of Saint Hubert as an economic centre, the original farm had become isolated, with poor roads. Leon went to the municipality, saying that they needed to either improve the road so that the children could get to school, or subsidize the move of the house to a location where the roads were already constructed. Bill Dean, as Reeve of the municipality, called to offer $\$ 1000$ of the $\$ 1500$ estimated cost.

First a new basement was constructed, with neighbours helping to pour the cement. Moving day was very exciting, with the children getting a day off from school to help or at least witness the event. Contractors were hired to move the house the six-mile distance. The movers had to choose the high spots across the fields since some of the roads were too narrow and low spots were soft with the rain that had come after harvest. Crossing the creek presented the most difficult challenge, given that the bridge was too narrow. Had the move occurred a week later, the creek would have been impassable because the water had come up.

The last part was winching the house slowly over the new basement. Dorothy was in the house, preparing a meal for the workers, and Pat was with her in the house. Always interested in everything, Pat was watching the activity both out the windows and through the furnace grill in the middle of the house. Suddenly, he declared, 'I know what they are trying to do, they want to put the house on top of that hole.'

With the additional land having both fields and pastures, Leon and Dorothy increased the magnitude of the operation as a mixed farm, taking advantage of all available labour and making the farm a central part of their children's identity. Rather than purchase the most powerful equipment, they purchased used machinery that required more labour time. The $1947 \mathrm{John}$ Deere $\mathrm{D}$ tractor is a good example. ${ }^{28} \mathrm{It}$ was powerful and reliable, but its high gear was only 5 miles per hour at full throttle. It would take an hour to move the tractor from one farm to the other, a good job for young teenagers (when the police were not watching). At the 2019 Calgary Stampede, Honory spotted a John Deere D tractor on display. He wrote: "When I saw it I could taste dust". Norbert added: "I was always scared going around the valley curves below Tait's ... what if a car came zooming towards me around the blind curve".

Gerry Adams sold the farm to Leon and Dorothy Beaujot in 1968 (Langbank and District History Committee, 1984: 206-207).

${ }^{28}$ The John Deere Model D was produced from 1923 to 1953, the longest production span of all two-cylinder John Deere tractors. Over 160,000 were made (Wikipedia). 
Since the new land included both fields and pastures, Leon and Dorothy increased their livestock, from two milk cows and seven other cattle in 1959, to four milk cows and 18 other cattle in 1960 . Their income from cream reached a maximum of $\$ 329.36$ in 1960 (see Table 6.4 at the end of Chapter 6 ). The production of cream was not efficient and there was no barn to house milk cows at the new location, with the last income from cream being \$81.42 in 1961. It was also in 1961 that their last two horses were sold. They were no longer dependent on horses for transportation in difficult weather conditions. Farmers had found that cattle could winter outdoors in the Saskatchewan climate, as long as there was shelter from the wind. In this way, Leon was able to increase his cattle herd to 35.5 in 1962 (18 cows, 4 heifers, 1/2 bull, 2 yearlings and 11 calves), and 71 cattle in 1966 (35 cows, 35 calves and 1 bull). In 1969 they purchased 40 feeders to fatten for sale.

However, Leon's allergies from hay and cattle were getting serious and the doctor advised him to lessen his exposure to cattle. The last entry for livestock was in 1970 with the sale of 31 head of cattle for \$7942.00 (see Table 6.4). It had been a worthwhile investment, also taking advantage of children's labour, especially for haying, but it was not worth the health risk.

Quoting Leon: The doctor said if I continued this way I would not be farming for long because it would kill me. We sold the cattle and I never went back to the hospital since. ... Compared to our neighbours, we were very unusual as a farm family without cattle. The farm animals represented an annual cash flow, however limited. There was less risk in livestock as it was less affected by weather conditions like frost or hail. Many had also depended on the home-produced meat to make it through tough times. However, as circumstances changed there were inefficiencies to mixed farming. A review of the account books with the VLA representative showed that the cattle were not paying off. ${ }^{29}$

Leon had minimized the costs of livestock by sharing the bailer and side-delivery rake with Gabriel Decelle, a neighbour whose children were then too young to help with haying. This also provided work for the older Beaujot boys, who were proud to be able to handle bales of hay in hot summer conditions. Jeanne Decelle always provided a lovely meal at the end of the day. After supper, they found new energy to unload the last of the bales from the rack, without the hot sun above.

Another activity associated with livestock involved the whole family. With pastureland on both farms, the cattle needed to be herded six miles down the road to the north farm in the spring, and back in the fall. There would be someone leading the way by car, another following behind in the truck, with the cattle being controlled by all available labour. The children learned quickly to know the signs of a cow that was going to bolt rather than follow the herd. Everyone could participate, if only by riding along in the vehicles.

There were many changes affecting the family in the 1960s. In 1960, all the one-room country schools were closed, and children were bussed to Langbank. Doreen was the first one to do all her schooling in Langbank. Leon was paid by the municipality to operate a snow blower on the tractor, clearing the way

${ }^{29}$ For instance, in 1969 , the income from livestock was $\$ 7,959$ but the purchases of cattle amounted to $\$ 6,257$. 
for the school bus and for the other vehicles using the road. This was a terrible job, having to get up early in miserable conditions, with the wind inevitably blowing the snow back onto the driver. Then in March 1965, Jeanette was born, the last child in the family. By 1965, there were seven going to school in Langbank, from Norbert in Grade 12 to Pat in Grade 1. With Leon no longer operating the snow plough, he could help with the production of school lunches. There were seven kits lined up on the counter as the children got ready for the bus. By 1971, Jeanette was joining Doreen, Adelin and Pat on the school bus. Leona, Honory, Norbert and Roderic were at university, with only Fred being in the full-time labour force.

In June 1967, the last grandparent, Paul Mullie died. He had lived to see the birth of all his 28 grandchildren, born between 1945 and 1965. Not only had he been an important farmer, experimenting with methods of farming and fruit production in Saskatchewan's climate, but he had helped his four children establish viable farms, three of which have continued into the third generation.

\section{The business of farming}

During their first years of farming, Leon and Dorothy were quite self-sufficient, producing much of their own food: meat, milk, eggs, garden vegetables and fruit, even collecting wild berries and hunting for ducks. Besides producing grain for the market, they sold eggs, cream and livestock. By 1971, they had specialized in grain production. Chickens were raised for their own consumption, with garden vegetables and fruit remaining important. Other than the farm yard and gardens, all available land was used to maximize grain production. Even fences were removed.

They were now farming 1 and $3 / 4$ sections (1,120 acres), which effectively had been three separate farms a decade or so earlier, each with a house and farm yard. The children were still important to farm production, with their wages entered in the farm account books $\mathrm{s}^{30}$, but they were leaving to study or work elsewhere as they were finishing high school. Increasingly, the farm operated as a business. They had paid municipal taxes, including education taxes, from the beginning, but the first record of an income tax payment in the account books was in 1967 when $\$ 797.50$ in income tax and \$1068.75 in municipal taxes (including hail insurance) were paid. An accountant from Capital Accounting had come around to encourage farmers to file for income taxes. The representative notified that, if a voluntary declaration was made on the farmer's net worth over the past four years, they would not be liable for non-payment of previous income tax. ${ }^{31}$

\footnotetext{
${ }^{30}$ For instance, the 1967 account book shows wages of $\$ 900$ for each of Fred and Honory, while the 1969, accounts show $\$ 700$ for Leona and $\$ 300$ for Doreen. Except for an entry showing $\$ 175$ in September 1959, Roderic's tuition at Gravelbourg was not entered in the farm account books.

${ }^{31}$ Government agencies, such as the Saskatchewan Ministry of Agriculture, were helpful in informing farmers on tax management strategies (Laforge, Cyril, 2020). In particular, there was encouragement to treat children's labour as deductible expenses against farm income. In the previous generation, Paul Mullie had avoided taxes by "gifting" transfers to his children, allowing them to buy land or pay other expenses.
} 
The account books for 1967 also show that Leon paid $\$ 158.40$ into the newly opened Canada Pension Plan. They had previously bought other forms of insurance, but they saw the CPP as important to their retirement income. Little did they realize how valuable the CPP would be, as early participants in the plan would earn a full payment after as little as ten years of contributions ${ }^{32}$. Unfortunately, it was not until much later that farm wives were allowed to participate in the Canada Pension Plan.

Leon was on the board of Langbank Credit Union for 17 years. He continues: We were not experts at deciding who was credit worthy, but we made things work for the benefit of the farmers in the community. Not being from Langbank, I had the advantage of knowing fewer of the people who were wanting to get credit.

We were always willing to try out new things, like forms of cultivation, chemicals, seeds. We went to seminars, in Saskatoon, Regina, even Lake Louise, where we would learn from the speakers and from other farmers. I remember one speaker in particular, who said that if you leave the farm transfer to the time of your death, there is often much trouble. It is important to do estate planning and to protect the inheritance for the children. We got piles of literature.

We changed pretty quickly to anything new, while a lot of people did not believe in change; for instance, they were afraid to increase their land holding by going into debt. They would say: "how will you ever pay for that." Old machinery can have the disadvantages of lack of reliability while new machinery can be very expensive. With farm equipment being visible in the fields, some people would increase too much, sometimes buying things for their "show off" value than for enhanced utility. Others would overdo it at the wrong time. It was important not to keep a machine for too long, you would get nothing for it when you trade it in, not more than five years or so for a tractor or combine. Also, I was not much of a mechanic and I did not want to pay the costs of having a machine overhauled.

When we started farming, we were the first in the neighbourhood to buy a one-way disk, six feet wide, to kill weeds and sow at the same time. Then we bought a disker, 12 feet. In 1951, our new Oliver combine was booked at $\$ 1,700$. Then, when we had bought more land in 1959 , we got a bigger tractor and we could pull two diskers, one behind the other. In 1960, we had Minneapolis Moline 5-Star tractor and pull-type combine worth $\$ 8000.00$, while in 1965 these were traded-in for larger Massey Furguson equipment worth $\$ 17,000$ (see Table 6.3). In 1983, the John Deere combine, complete with push button attachments, goes into our farm record book at $\$ 69,600$ (Langbank and District History Committee, 1984: 209).

Table 6.5 carries figures on the farm inventory and net worth in 1960, 1968 and 1977 (see Table 6.5 at the end of Chapter 6). Although the dates are somewhat arbitrary, 1960 is the first year of farming 5 quarters, 1968 is the first year with 7 quarters, and 1977 is the last year for which farm account books

\footnotetext{
${ }^{32}$ The CPP is less valuable to younger generations who have to make contributions of $9.9 \%$ of their income (up to the maximum income subject to contributions) for 40 years in order to receive the full payment as of age 65 . In contrast, the early participants were contributing at the rate of $3.6 \%$, including the employee and employer amounts, for as little as 10 years, to receive the same benefits.
} 
have been located. While it is difficult to estimate, after adjusting for inflation, the net worth of the farm would have increased 3.4-fold between 1960 and 1977. ${ }^{33}$ In 1960, the livestock consisted of two horses, four milk cows and 18 other cattle, the 1948 Dodge car was still in operation, valued at $\$ 400$, municipal taxes amounted to $\$ 816$, and debts amounted to $\$ 14,456$ on land and $\$ 2,300$ on machinery. The nonfarm income amounted to $\$ 648$ for Family Allowance and $\$ 240$ in rent from Paul Mullie.

In 1968, the year had started with 29 cows, one bull, 26 yearling calves and one horse. With the sales during the year (amounting to $\$ 8,707)$, there were 16 cows, one bull and one horse at the end of the year (valued at $\$ 4,050)$. The grain sold in that year brought a further $\$ 12,936$ in income. The wage record shows $\$ 660$ for three months work by Norbert and $\$ 950$ for 12 months by Honory. In 1970, the wages would show $\$ 150$ for Leona, $\$ 200$ for Doreen and \$150 for Adelin.

In 1977 , grain was the only source of farm income, amounting to $\$ 70,030$ or 3.2 times the income for grain and livestock in 1968. The books for 1977 also show: Family Allowance of \$352, VLA payments of $\$ 1,430$, other loan payments of $\$ 2,070$, municipal taxes of $\$ 2,077$, insurance of $\$ 1,744$, income taxes of $\$ 253$, and wages to Adelin and Pat of $\$ 1,109$. Fred and Karen were on the farm that year, with total wages shown as $\$ 2,600$. The outstanding loans in 1977 were $\$ 28,080$ to the VLA and $\$ 21,660$ to the banks.

In 1981, a Prasco air seeder was purchased. This air seeder system was state of the art. The design was more efficient at seeding and fertilizing than the previous gravity-based systems. The seeder could be attached to cultivator-style implements and operate as no-till. That is, the clearance was enough to enable sowing directly in the stubble, delivering both seeds and fertilizer as the soil was cultivated. The same implement could be used to put fertilizer into the ground in the fall. This fertilizer was cheaper than the type that would be used in the spring. Then in the spring the same machine could be used for seeding directly into the soil with no additional cultivating. This was part way toward the zero-till idea. ${ }^{34}$

Leon continues: After we purchased the Prasco air seeder, we mostly did continuous cropping, much before zero-till came out. We also did not burn the straw, except for the flax straw which was impossible to handle other than by burning. We had gone on a tour organized by the Dean of the School of Agriculture at Saskatoon, to see some farmers who had fields that were in continuous cropping and preserving the nutrient value of the straw.

In contrast to continuous cropping, the practice of summerfallow in the Prairies dates to the Bell Farm at Indian Head. In 1885, this large farm was without their horses which had been commandeered to fight

\footnotetext{
${ }^{33}$ The account books for 1978-86 have not been located. The inventory for 1977 shows a second set of figures giving a total value of $\$ 472,600$ for land, buildings and machinery (p. 111) compared to the value of $\$ 251,940$ recorded in Table 6.5. This indicates the difficulty of properly estimating net worth.

${ }^{34}$ This Prasco air seeder was used from 1981 until Leon and Dorothy stopped operating the farm. Their sons Norbert and Pat, who subsequently operated the farm, continued to use the seeder until 1992 when they had successfully seeded with the no-till system that they had developed. While it was 10 years old, the Prasco tank and Leon cultivator was still a valuable piece of equipment, selling for \$10,000 in 1992.
} 
against the North-West Resistance (Briere, 2009). With more moisture accumulation, the following year produced a "bumper" crop. The Dominion Experimental Farm at Indian Head subsequently did research on "fallowing the land" or "summerfallow" (McClinton, 2017; Johnson and Smith, 1986). Leaving given plots of land fallow every two-to-three years, sometimes even every other year, became the dominant practice. This allowed for control of the weeds during the fallow year, and for moisture accumulation. Only later was it realized that the practice seriously reduced soil quality. Continuous cropping would produce higher total grain production, averaged over years. With larger equipment and alternative ways of controlling weeds, direct seeding or zero-till would later reduce the energy intensity of farming operations and trap more of the snowfall moisture for the following year's crop.

Leon adds: Some did not make a go of farming, they were not cut out to be farmers. For instance, my cousin Emile Gatin would have been much better as a mechanic. Some farmers stayed with the same way of doing things throughout their farming days. Others did not want to quit farming and retire.

We also did not go too far into debt; we did owe money, but not enough to scare the bankers. Everything that we made went back into the farm, we did not have too much spare money until we retired. Nonetheless, we always gave priority to the children's education, which was like putting money into the farm. We also took trips in the summer, almost every year, and we went to Europe in 1976 when we were still farming. We went to Farm Progress Shows and attended conferences on farm information in Saskatoon, Regina, Indian Head, Brandon, Calgary and Lake Louise.

In Langbank Memories (1984: 207-209), Leon and Dorothy Beaujot write: We have always kept in touch with the latest in farming practice by attending meetings, conferences, seminars, agronomist tours, crop and soil courses every year. We are grateful to the University of Saskatchewan and its Agriculture staff for their research on cropping practices and farm management. The latest being continuous cropping and minimum tillage. The use of advanced engineering and technology in farm machinery, such as the Prasco air seeder, has also been a great help to us.

At the beginning of their "mixed farming" operation, the crops were oats, barley and wheat. Knowing that crop rotations ensured better weed and disease control, along with soil replenishment and straw management, they introduced alternations between cereals (wheat, oats, barley, canary seed, fall rye) and broad leaf crops like flax, canola, mustard and faba beans. Besides this diversity, Leon and Dorothy were always trying new crops and varieties and choosing crops that showed promise of better prices.

\section{Births and Birthdays}

Quoting Leon and Dorothy: We were both born at home, as were all our siblings, but by the time our own children arrived, things were different. During the war, there had been deaths with scarlet fever, and the doctor in Whitewood had not wanted any more births to occur on the farm. It was still hard to make our way to hospitals, depending on the state of the roads. For Roderic's birth, on 22 April 1946, we were lucky that the roads had just opened, and we were able to drive to Whitewood with the old Model A that we had purchased from Raymond Mullie. The roads were very muddy, but it was quite 
safe. At that time, new mothers were to stay in bed for most of the eight-to-ten-day hospital stay. Dorothy continues: when you first get on your feet, you are so weak that you feel dizzy and almost fall over.

Norbert's birth, on 11 February 1948, was in the dead of winter. Dorothy's parents had come a week earlier to stay with Roderic. The plan was for Dorothy to stay with friends in Whitewood for the week before the anticipated birth. But the birth came a week early. The trip to Whitewood occurred in the middle of the night, over hardly visible tracks in the snow. We used our closed-in cutter, borrowed from the Montie Cross family across the valley, pulled with a team of horses. The 17-mile trip took at least three hours in -20F temperatures. We left at about 6:00 pm, when it was already dark. There were snowbanks on the roads, but we needed to follow the track that had been built up. The horses were very strong and very good at seeing the trail in the dark, but occasionally they would get off the road into the soft snow. Leon wanted to change horses at a farm five miles from Whitewood, but Dorothy insisted that we press on. Leon had to stand on the front of the cutter to hit and yell at the horses as they were played out. He pushed the horses so hard that they were never the same again. Mother and son came home with a snow plane that Montie Cross had purchased and was using to make trips in medical emergencies (cost of $\$ 5.00$ ). A snow plane has a propeller behind and the only difference with an air plane is that it glides on the snow rather than flying in the air. Leon's cousin built a snow plane for the St. Hubert convent.

Fred (originally Freddy) chose a better time to be born, on 29 September 1949. This time the trip was to Kipling in our one-year old 1948 Special Deluxe Dodge. The birth came quickly, in time to occur on his father's $30^{\text {th }}$ birthday. That morning, Dorothy had wished Leon a "happy birthday" and asked if he would like a baby for his birthday, to which he replied, "that would be nice". As they started on the chores for the day, Dorothy said: "I'm serious! Get the car, I'm going to have the baby!".

Honory was born on 16 May 1951. By now, the doctors had realized that it was best for new mothers to walk around after the birth, but they still used a complete anesthetic and kept us in hospital for a week or so.

Leona was born on 4 June 1952. Finally, a girl, but she had to be strong to keep up with her brothers who taught her to walk at nine months. Leona planned her birthdate very well, after seeding was finished and before the haying would start. There was a lull in the busy farm life and always time for a birthday picnic in the valley. One year, Leona asked me if she had remembered to bring the candles for the cake. I had remembered the candles but forgotten to bring the cake!

Doreen chose 21 April 1954 for her birth. She got to have her birthday the day before Roderic for the rest of her life. With two girls, we needed to have a girl's room in the house. We were lucky that Doreen settled close to home, bringing grandchildren into our daily lives.

As Adeline's birth was anticipated, it was clear that it would occur in the middle of the winter. Suddenly there was the hospitalization and death of Bertheline Beaujot, on 19 December 1955, and Leon had to 
go to his mother's bedside in Regina. He rode horseback through the deep snow to Saint Hubert then he and Albert drove to Regina. With six children under ten at home, these were very anxious moments to say the least. Thinking back, Leon says that he should not have gone to his mother's death bed. But one is not thinking straight when it comes to a mother's unexpected death. For the birth on 8 January 1956, Montie Cross brought Dorothy to Kipling with his bombardier snow plane. ${ }^{35}$ Adelin got to have the first birthday of the year.

More than three years later, Patrick was born on 18 April 1959, to have a birthday three days before Doreen. As the only boy at home, in 1971, Pat was left to defend his parents' decision to go out of cattle.

Almost six years later, Jeanette was born on 24 March 1965, remaining our baby for the rest of her life. When she was in high school, she was the only one at home. In 1982, Jeanette got to go with us, to Argentina, for Honory's wedding. We were lucky that she too settled close to home. Later, when her son Mark was playing baseball, Leon could cheer him on, bringing fond memories to Grandpa.

\section{A family affair}

Leon and Dorothy always made important decisions together. Whenever he was purchasing equipment, Leon would break off the negotiations before finalizing the deal, saying that he had to consult with his wife. Having worked on her father's farm, Dorothy was very knowledgeable about farming. They enjoyed watching the fields together and discussing the progress and quality of the crops. In talking with other farm wives, Dorothy was dismayed to hear that they sometimes did not even know what crop was being grown in which field. They would go to farm progress shows together, especially after they realized that this expense could be used as an income-tax deduction.

Leon was heavily involved in gardening, including preparing the soil, planting, weeding and harvesting. He was also the main person doing the milking and separating the cream for market. He operated and cared for the farm machinery, purchased the seeds and fertilizer, and brought grain and livestock to market. Since he was going to town for farm purchases and marketing, he was also the one buying groceries. When there was more bread being eaten by the growing family than could be baked at home, Leon made arrangements with the baker in Whitewood so that Stan Blyth would to drop off day-old bread as he was making his delivery to Kipling.

At harvest, when time is of essence to get the crop off before it spoils in the field, combining occurs from the departure of the dew in the morning until it comes back at night. Leon would be on the combine, and Dorothy with the truck bringing the grain to the granary, children in tow. Dorothy needed to be watching carefully when she expected the hopper on the combine to be full, then Leon would wave, or flash the lights at night. Pulling up to the combine at the appropriate location, the grain would then be augered into the truck. When conditions were good, the truck could be driven as the grain was being unloaded "on the go."

${ }^{35}$ A January 1956 entry in the farm account book shows a $\$ 10.00$ entry: Montie Cross trip to get Dorothy in Kipling. 
An auger was used to put the grain into the bin. Before trucks had lifts, unloading the truck was a hard job because all the grain had to be shoveled out of the truck into the auger. The auger needed to be started with a pull rope, and the children needed to be kept away from the danger. All this needed to be done in time to catch the next load of grain from the combine. Dorothy enjoyed telling the following story: Once, I had unloaded the grain, and I found that the truck could not be put in a forward gear. I tried first gear, but no luck, then I tried second gear and still no movement. I found that reverse worked fine so I backed the truck all the way out of the yard and into the field to the combine. Leon had been wondering why it took so long, then he could not figure out why I was coming backwards. We agreed to continue to use the reverse gear rather than fix the truck, but we would not try to "unload on the go." Doing this in reverse was beyond my abilities.

In 1961, a dump truck was purchased so that the truck box could be lifted mechanically to an angle that allowed the grain to flow out the back. 'That was something, that dump truck,' says Dorothy.

On the occasional night, there is no dew and combining could continue to midnight or even later. If it was time to put the kids to bed, Leon could continue by himself. The truck would be left in the field and the combine driven to the truck when the hopper was full. Unless there was a threat of rain, the last truck load could be dealt with in the morning, before the dew lifted.

Harvest was a fun time for the whole family. All activities were dedicated to bringing in the crop. Meals were brought out into the field so that the combining could continue uninterrupted. The meals were delicious, benefiting from a garden that was producing at its most, including tomatoes. As they grew a little older, the children would learn to judge the quality of the combining, checking that the threshing was giving a clean hopper of grain and that minimal grain was passing through with the straw and chaff out the back of the combine. There was danger to being so close to a combine with belts and chains turning, but they were always careful. That was before the electronic sensing devices that now perform these functions.

From about age 7, Roderic had been taught to steer the tractor in the field, for simple jobs like pulling a rack being loaded with hay. He could not reach the clutch with his foot, but he had been taught to shut the switch if there was a problem. For collecting bales of hay in the field, Leon would get the tractor going in the right direction, very slowly, and he would go onto the rack, reaching with a hook the bales of hay that had been lined up. At the end of the field, Leon would jump back on the tractor to turn it around, making the return trip against the next row of bales.

The children all worked on the farm from a young age, doing various chores in the barn, yard and fields. However, whenever there was homework to do, that got priority. Everyone participated in gardening, especially sowing and harvest. Harvesting potatoes was a job that all could do, from finding the potatoes that had been dug up with the cultivator, to collecting them in the truck and unloading them into the basement. The peas would be shelled in the house or in the shade. At the threat of frost, all would be out collecting tomatoes. 
From the long hours in the field, especially in working the summerfallow, the children learned the importance of being systematic, making straight lines to avoid both misses and over-tilling. They also learned to be patient in doing boring work. In gardening, they learned to search for the best conditions for plants to produce and the importance of timing in taking advantage of the growing season. In all things, they learned to be frugal and to maximize production.

The children got to test their math skills by helping with the farm account books and the various calculations associated with grain production. Leon would get his children to make the calculation, for instance on how much chemical was needed for weed kill in a given field, but he always knew if they had got the wrong answer. These calculations became very complex when metric units of measurement were introduced: To put a certain volume of chemical on given area of land, the chemical needs to be diluted with an associated volume of water. The tractor then needs to travel at a given speed, delivering the liquid with a given amount of air pressure. One could easily make a mistake that would either destroy the crop or not kill any weeds!

Leon was particularly good at bringing his children into decisions. He would even do this with small things, or on questions where he had more expertise, especially compared to a child who was just home for holidays. This created conversations, and it gave everyone a sense that this was their "family farm". This approach to decision-making can be puzzling to in-laws, especially if they are from families where parents make the decisions. The in-law can feel that a decision has been made, but somehow the question is opened-up again for all new parties to the conversation.

\section{Learning: At school and on the farm}

From 1953 to 1960, the children went to school at Golden Plain (the same one-room school that their mother had attended). The school was 3.5 miles from their home. When the roads were good, Leon would take the children to school by car, but that was not possible when the roads were closed in winter, nor when the roads were muddy. In the winter, the sleigh was used. When the roads were muddy in the spring or after a rain, the transportation was by horse and buggy.

In the first year, with Roderic the only one at school, Leon would take him on horseback when the roads were not passable. In the second year, Norbert and a neighbour boy were also going to school, making the trips more efficient, with the two fathers sharing the responsibility. In the third year, the children were taught to take the horses by themselves, after a few practice-runs. They would meet another set of children who were a little older (Harvey Dumonceaux), who would help to unhitch the horse and put it in the barn on the school yard. At noon, the horses were fed, then at the end of school day the older children helped again to hitch up the horse for the return trip. Gradually, as the roads became better, the transit to school was more often by car and truck than by horses. But when the roads were impassable by car, horse and buggy or sleigh had to be used. 
Golden Pain School closed in $1960^{36}$, and Doreen was the first one to start school in Langbank, by bus. Transportation by school bus necessitated the roads to be opened. For three or four years, Leon ran the snow blower as part of a club that opened the road for the bus to pass. Better road access to school was a key question prompting the move from the north farm in 1962.

The farm itself was an ideal place for learning through experiments of various kinds. To find out how an electric fence could control cattle, the older boys wired a poker to the radio battery and they found that the cat would fear the poker, even though it carried little or no electricity. The trick was to have an animal put its nose to the electric fence and thereafter it would stay away from the fence.

Honory took interest in Angora rabbits and he was proposing an investment in this alternative agriculture. Further research determined that this was a pyramid scheme. Through these enquiries, various written material had arrived on raising these rabbits. Adelin used these documents to make a school speech. Her speech was so convincing that a rumour spread to the effect that the family was raising rabbits in the empty farm house across the road. Denials did not help, as people simply thought we were being particularly cagey in keeping our rabbit-raising activity under cover.

The most memorable invention was Honory and Fred's motorizing an old buggy. As there were no horses left, they sought to use the buggy in another way. Various motors and pulleys were tried. The challenge was to make a device that would serve as a clutch. Brakes were a frivolity because friction would bring the contraption to a stop once the motor was disengaged. To everyone's surprise, Honory and Fred were able to drive his buggy the 9 miles to Langbank. It was very hard to steer, but they managed to keep it on the shoulder of the road. The cars honked as they passed by, some even stopped to have a look and ask questions, but luckily none of them were police cars.

Dorothy and Leon were always there to help with school work. Dorothy continues: Roderic was always asking for spelling lessons, but it did not seem to help. Norbert and Doreen hated reading. Roderic and Leona tried to help but they were poor teachers. Honory recalls being stressed in Grade 2 as he tried to learn the words for dictation: Mom told me that I needed to memorize all the words in the list before learning how to spell them. I still remember the list for Lesson 7 in the Grade 2 Speller: Be, So, Was, Can, Boy, Will. Needless to say, I got $100 \%$ for the first time. Thanks, Mom.

The parents bought an encycloaedia to help with school projects. Projects and speeches were discussed at the dinner table, as everyone pitched in.

Pat recalls, when he was in Grade 6 or 7, from the time when he was the oldest boy at home, that his Dad would take him out walking the fields, discussing the state of the crops, how to control the weeds, and the new things coming out in farming. The children all profited from the way our parents brought us

\footnotetext{
${ }^{36}$ There were 18 students at Golden Plain when it closed in June 1960 with Mr. Peufalt as the last teacher (Langbank and District History Committee, 1984: 206).
} 
into decisions. There was certainly much work to do, but their approach made us feel that we were participants in operating the family farm.

\section{First jobs}

The children also got help in finding their first jobs. Lee Gatin, Leon's cousin, showed Roderic how to apply for a summer job as a rodman for the Saskatchewan Department of Agriculture in the summer of 1966. When one of the workers from the Department of Agriculture had an accident, Norbert managed to get a similar job later in the same summer, as he finished Grade 12. This influenced his continuing interest in Agricultural Engineering.

After his Grade 11, Fred followed Roderic to Thompson, Manitoba, getting a job as a short-order cook, a skill that served him well for the rest of his life. When he returned home for Grade 12, Fred took to importing from Europe and selling cuckoo clocks, steak knives and electric razors. While the clocks did not work well, especially before the packaging had been properly removed, and there were limited sales, he gained accounting skills.

When Honory was in Grade 11, his father spoke with some people at Wolseley who were working on the pipeline, asking if they might have a job for a good worker. The foreman said that he had just fired someone who was unwilling to work in the mud. Leon assured the foreman that this farmer's son would be willing to do the work. Honory was offered the job, as long as he was willing to spend the first of it working in the mud. Through university, Honory continued to work on the pipeline in the summer, and later in pipeline design.

Leona was told by her principal that she would be good at teaching Math and French. She worked at several summer jobs to earn money for university. First as a waitress at the Kenosee Lake Resort. After completing two years at university, she and her friend Linda Bakos decided to take a year off to work and travel through Europe: "After all, if Norbert and Roderic could do this, so could I." They worked in Claresholm, Alberta for ten months as nurse's aides at a hospital for mentally and emotionally disturbed adults. Once in Europe, they worked in at the Novotel hotel restaurant in Paris, as waitresses, learning more French. Leona's cousin Thérèse Laforge got them these jobs at the Novotel where she was working. Then they did 5 months pack packing in Europe. Leona's last job that year was at the Calgary Stampede dealing cards at the Black Jack tables, honing up on the Math skills.

Along with Leona, Doreen and Adelin also worked at Kenosee Lake Resort, boarding with Leon's cousin, Jack and Cathy Pirlot.

Because of her fond memories of travelling in B.C. with the family when she was 10, Adelin longed to someday work in the Okanogan orchards. This dream came true in her early 20s. She was so awestruck when she arrived that she immediately got lost in the orchards. Adelin's first teaching job was in Rosetown, Saskatchewan, replacing a teacher on maternity leave. In her mid-20s, Adelin travelled to Australia and New Zealand. She found work in house-cleaning and picture framing. Getting around by 
bicycle, she once drove right into a car that had opened its door in front of her. She was "doored" even before the concept was invented!

With help from Honory, Pat got a job working on the pipeline. He then spent two summers doing custom combining with American friends, starting in June in Texas and working their way up to Canada by September, learning about agriculture in North America. He also found that American girls wore very little clothes, because of the heat, when they worked as helpers in grain delivery.

For Jeanette, Leon again went to talk to a fellow in charge of pipelines to see if she might get a job there, taking advantage of a little truck that had been purchased for her. The foreman said that she would be the only girl with a bunch of men, but he would ensure her safety. Jeanette soon learned that in some circumstances she knew more than the men. Once she was stuck in the mud and the other workers were putting extra weight on the back of her front-wheel drive, only to make things worse. Once she got them to put the extra weight on the front, the little truck easily came out of its predicament.

After she finished school, Doreen worked at Fred's Bakery, then at Leggett's Grocery store, in Kipling. Then Doreen upstaged three of her older brothers, and her older sister, by getting married at age 19. She had become an adult while others were still students and trying to figure out what to do with their lives. Later, they would be jealous that Doreen was the first to have grandchildren of her own.

Roderic and Norbert took to hitchhiking when this was popular in the late 1960s. Leon continues: Since they were doing it, we took to picking people up. We met many interesting people. Leona adds that hitchhiking was not strictly for guys: "My friend Linda Bakos and I did this in Europe and Saskatchewan as well. We probably didn't tell our parents."

\section{Family visits and travel}

Travel was another activity that made for family togetherness. For many years, travel involved visits with relatives. Trips to Regina inevitably involved a visit with Ernest and Anita Gatin, Leon's first cousin. In 1940, Emile and Anita had been the first to move from Saint Hubert to Regina.

Once or twice per year, including for Christmas if the roads were passable, the family went to Handsworth, where Leon's sister Flora and Joe Driscoll had settled after their marriage in 1931. Leon recalls a time when the $80 \mathrm{~km}$ trip took all his driving skills: We were returning in the mud, and we made it half way down the last mile through the fields from the north, by racing the car so that it did not get bogged down. Paul Mullie was with us, and we walked the last half mile in the mud. Dorothy carried Fred, Leon carried Norbert, and Roderic held onto his grandpa's pocket to maintain balance.

Particularly memorable were the trips to Arborfield and Zenon Park, where Dorothy's brother Mike and Jeanne Mullie and sister Marie Louise and Philippe Laforge, had settled after their marriages in December 1944 and January 1945. In the earlier generation, Dorothy's Uncle Julien had established a homestead at Arborfield in 1913, a 300-mile distance from Saint Hubert. With Dorothy's older brother, 
Raymond and Maria Mullie, living a mile's distance from Dorothy and Leon Beaujot, there was much interest in visits back and forth, for both parents and children. These summer trips were a fun time for all, with piles of cousins the same age, and Uncle Julien's strawberries producing more than they could eat. Jeanne and Mike even made ice cream before there was refrigeration, using ice from their ice house that still had blocks of ice in mid-summer.

With crops that did not need immediate attention, it was the right time to have a holiday, comparing notes on family, farming and weather conditions. Mostly, they were times of family bonding and fun, bringing back the behaviour of youthful years for the parents, and bringing an enduring sense of belonging for the generation of first cousins.

Dorothy continues: We made our first trip to Arborfield in the fall of 1946 (Roderic was three months), and mostly every other year. This brought us back to our teenage years, when we first knew each other, and to our 20s when we had gone through a war together. There were some years that it rained so much that we did not travel. One year we left Leona at with Flora and Joe, then went with Mike and Jeanne Mullie's family to Prince Albert and Waskesiu Lake. Another year, we followed two trucks on the gravel roads and were not able to pass for many miles because of the dust. It was a full day's drive with everyone excited to get there.

In the late 1950s and early 1960s, there were trips across the U.S. border to buy clothes at Minot. The Canadian dollar had a good exchange rate, and children's jeans were a particularly good buy at "a buck or two" says Leon. While one needed to stay 48 hours to benefit from duty-free, wearing several layers of new clothes did not raise suspicion in crossing the border.

Church at Saint Hubert would be occasions to visit Grandma Beaujot who was living in the hamlet with her son Albert working as a carpenter at the Joan of Arc Nursing Home. Continuing after Bertheline Beaujot's death in 1955, there were frequent occasions to see Albert, sometimes on the farm where he would come to help, sometimes after Sunday mass.

In about 1955, Albert and Grace Pelletier came to live in the house that Albert Beaujot had first built for his retired parents in the hamlet. Albert Pelletier also worked at the nursing home, and they had two children of similar age to Leon and Dorothy's oldest. The visits to Saint Hubert came to include the Pelletier family. At one point, Leon and Dorothy travelled with Albert and Grace to take advantage of the cheap clothes that could be purchased in Minot, staying 48 hours so they could legitimately bring things back duty-free. While the two couples were away, Albert Beaujot looked after the Beaujot and Pelletier children at the farm.

Under the pretense of saving on heating bills, Albert Beaujot came to live with the Pelletier family. There was more intensity in 1959 when two births occurred within weeks of each other: Patrick Beaujot and Alan Pelletier. Roderic recalls Albert Pelletier laughingly saying that his son looked like a Beaujot. This became clear when a second child was born in 1963, as Albert Beaujot and Grace Pelletier left with their 
two young children to eventually live in Calgary (see the entry by Albert Beaujot in Memories of St. Hubert 1980: 60-61).

This new relationship brought hardships between brothers Albert and Leon Beaujot who had shared much of life, with Uncle Albert being a favorite "Mon Oncle" across the Beaujot and Driscoll families. Eventually, especially as their sister Flora Driscoll ${ }^{37}$ also moved to Calgary in 1972, the relationships across brothers improved along with more reasons to travel to Calgary.

The family's first major trip other than to Arborfield was in 1963, to the Black Hills of South Dakota. Dorothy and Leon continue: Pat was two or three, and we were trying to get the better rates available for children under 10. We had Honory and Fred practice saying that they were nine-year-old twins, and suddenly Leona declared to the person issuing entry tickets that she was ten, breaking the pretense. Other incidents are well remembered from this trip. After eating too much fresh fruit, we were looking for an outhouse or toilet on the horizon, or even a sign showing the distance to the nearest town. As we were piercing our eyes to read an oncoming sign, we found it saying, 'Trust in God.' Those Americans with their signs! Honory, Fred and Norbert went up the mountain at a tunnel. Leon went up and could not find them. Roderic found them but then he too got lost. Leon continues: We were quite worried, even enquiring about getting helicopter assistance. Eventually, our four boys were back again, safe and sound. On the way back, observing the fields being combined, Leon was worried that he had stayed too long. But by the time we crossed the border to Saskatchewan, the fields were still green.

Leon continues: In 1966, we made our first trip to the mountains. All the way there we were talking about the mountains, but it was so foggy that we did not see them until the next day when we were in Penticton. Fred and Honory were the eldest travelling with us, and Jeanette was left with Irene Szilagyi.

For the trip to Expo 67 in Montreal, we left Pat with Anne and Sylvain Dumonceaux, and Jeanette with Jack and Marie Driscoll. Roderic was working at Expo and he took us around to the various pavilions. We made a side trip to Quebec City to see sights, but it was such a rainy day that we could not get out of the car. At least we drove around the Plains of Abraham, but Adelin was confused because she could not see the planes that seemed to excite the rest of the family. We stayed with Gilbert and Ruth Mullie and Joe and Tillie Mullie. On the way back, we spent a day with Alfred and Margarite Mullie at Lafontaine. A great trip with an old Ford station wagon. It was handy to have three kids facing the back window, that way I didn't have to look in the rear-view mirror!

In 18 February - 30 March 1976, Leon and Dorothy were six weeks in Europe, with Leon's sister Flora ${ }^{38 .}$ They started with a bus trip that took them to Belgium, Germany, Austria, Italy, Switzerland and France. They then visited relatives on Mullie, Beaujot, and Sénéchaud sides of the family. They first visited Roger

\footnotetext{
${ }^{37}$ Flora and Joe Driscoll sold their farm to their son Leon in 1965 and moved to Kipling. Joe died on 1 January 1972 and Flora moved to Calgary later that year (see Flora (Beaujot) Driscoll Memories, 1992).

${ }^{38}$ Pat and Jeanette, aged 16 and 10 at the time, stayed with their sister Doreen and Dean. In recalling this time, Pat was prompted to apologize for the anxiety that he caused his sisters, and to appreciate the wisdom of his parents not to have left he and Jeanette alone on the farm.
} 
and Marguerite Domicent in Brussels. They were then transported by various relatives or by bus to visit others of Dorothy's first cousins on the Mullie side in France: Henri and Renée Mullie in Calmart (near Paris), and the farms of Pierre and Thérèse Mullie at Foncquevillers, and Thérèse and André Lanthiez at Hondainville. They did not manage to go to Normandie, but they had been in contact with these first cousins who visited in Canada: Jean and Nicole Mullie from St. Romain de Colbosc, Marcel Mullie from Les Loges, Bernard Mullie from St. Jean de Folleville, and Father Robert Mullie from Ste Addresse (near Le Havre).

When visiting on the Beaujot side in Belgium, they established the family tree of the descendants of Leon's aunts Léopoldine Poncelet and Marie Godart at Patignies, Malvoisin and Bourseigne-Vieille. At Rienne, they saw Arthur Parent (spouse of Agnès née Poncelet) and their children Marthe and André Parent and Léon and Claire Parent. At Bourseigne-Vieille, they saw Maurice and Augusta Godart. This provided the missing parts of what became Descendants of/de François and Justine Beaujot: 1860-1979 (Beaujot and Beaujot, 1979).

Back in France, they visited especially with Leon's first cousins Raymond and Germaine Largeau in Saumur, André and Marie Largeau in Parthenay, Marcel and Joséphine Largeau in Sugères and Albert and Aimée Sénéchaud in Lhoumois where they also saw Alice and Nestor Martin.

\section{0 ${ }^{\text {th }}$ Wedding Anniversary: 14 July 1985}

Leon and Dorothy's $40^{\text {th }}$ Anniversary brought the family together for several days. There was much discussion of retirement and the implications for the family farm. Norbert and Pat were advancing their plans to establish Seed Hawk and to build no-till seeders at a location between the Beaujot farm and Langbank. The discussions in the family centered on working out an arrangement with Norbert and Pat to take over the operation of the farm. With the enthusiastic agreement of the other children, an agreement was established where (1) Norbert and Pat would each buy part of the property and all of the equipment, (2) Leon and Dorothy would retain ownership of part of the property that Norbert and Pat would rent from their parents, (3) life insurance and provisions of the will would ensure that the other children would later receive their fair share of the inheritance. The farm would stay in the family!

As we were reflecting on these 40 years, Leona prepared two lists. The first one was called Funny things which happened to Mom and Dad:

1. Mouse in the piano running across the keyboard in the middle of the night ... there must be a ghost in the house!

2. The Exhibition in Regina - with the money they had for furniture, Dad thought he would make a fast fortune by gambling ... need I say what happened.

3. Dad running into a parking meter in Regina, chest first ... then bum first on the ground. Watch where you're going Dad ... not at those pretty legs across the street!

4. Mom and Dad sitting on a freshly painted park bench in Argentina. They should have taken Spanish lessons before making that trip. 
5. And then on their return from Rio, one engine on the airplane gave out over the Atlantic. Not so funny when the announcements are in Spanish, and the airplane has to dump fuel (was it over the Bermuda Triangle?) to land in Miami, then spending the night trying to sleep on hard airport benches until the next flight. Pat Smeets, sister to their neighbour Arsene Smeets, was still able to pick them up at the Winnipeg airport, two days late.

6. Dad getting almost lost in California at the age of one. Thank God that didn't happen for we all wouldn't be getting together today for this reunion, Mom might still be looking for a husband, and Rod's population growth chart would all have to be redone.

7. While Dad was in the army, Mom used to write him mirror image letters. I think their first fight was over something Mom did backwards!

8. Dad, did you ever get those baseboards put into the house ... from 40 years ago. I know how much you like carpentry work.

9. And then there was the time, after one of those famous Saskatchewan snow storms, when Dad walked out to do the chores ... and there was no barn ... it had disappeared under the snow.

Leona called her second list "The family with 9 lives", even though there were more than nine entries:

1. Roderic rolling out of the truck as his Uncle Albert was going to pick up a hopper of grain.

2. Fred getting stuck with his bum in a 5 gallon pail.

3. Pat, at age two or three taking a run for the open doorway to the basement, and being caught by his Dad, with one hand, as he was separating cream at the bottom of the stairs. Adelin recalls the same story, but it was she who was flying through the air. Doreen confirms that it was Pat's story. Norbert recalled the story of Dad catching him as he wiggled his crib over the edge of the doorway. All are grateful that Dad's baseball skills came in handy in catching children.

4. Fred showing off to Honory by jumping off the barn roof. On landing, a nail coming through his shoe ... between toes.

5. Honory and Leona lighting the prairie on fire. Honory tried to forget this incident, but Leona turned it into an essay in her French class at the University of Saskatchewan. The prof found it so good that he read it to the class.

6. Lynn (now called Adelin) getting to church without underpants.

7. Leon hated even the smallest of electric shocks, so when he was installing an electric fence, he asked Doreen, who was nearby, to touch the wire. Sure enough, he had the wire right and she got a shock. Doreen says: "Dad thought it was funny, but I was not happy. Years later, when we got a cool green shag rug in the living room, I would give Dad a static shock. Pay back!"

8. Rod and Norbert getting caught in a gopher hole in the sand pit down the valley.

9. Fred breaking his wrist trying to save time by jumping the barnyard gate instead of opening it, as he tried to get the chores done during an ad on TV, not wanting to miss any of the show.

10. Fred, on his way to school, smashing his toes under a barrel full of water in the back of the truck. Those in the front seat thought he was just banging on the window to get into the cab of the truck. When he convinced the teacher that his toes were badly hurt, he finally got more attention, with Mom bringing him to the doctor.

11. Honory throwing the electric cord into the bucket of water where Doreen and Leona were in the yard washing their feet. Pretty shocking, says Leona! 
12. Fred boarding up the granary door and getting his head stuck inside as the second to last board was nailed in.

13. Fred lifting baby Pat onto his shoulders but instead dropping him over his back, with Pat headfirst on the floor.

14. Honory, Fred and their sisters riding the horseless buggy down the hills at the valley, and Honory arriving home with a deep scratch across the cheek as they hit a barbed wire fence. Mom asked him: "What happened to you?". Seeking to avoid the question, Honory eventually said: "Oh, I've had this for a while."

15. Adelin wondering where the "Plains" of Abraham were. She couldn't see any "planes" at all!

16. Pat driving into a horse that landed on the roof of the (possibly speeding?) car.

17. Honory having a rest at the side of the field, not realizing that his Dad was finishing the mowing by going around the same edge of the field.

18. Learning to ride on very oversized bikes, Adelin thought she had broken her toe as she was going downhill with Doreen. Her sister ripped off the bottom of her shirt to wrap up the toe, then hightailed it home to get Mom to come out with the truck. The toenail had ripped off, but nothing broken.

19. Pat spent many hours in the three big poplar trees in the yard, climbing up and hanging out: Mom and Dad didn't know I was up there but sometimes I would yell at them to get their attention. They would always say: "Be careful". I got pretty good at scooting up and going from tree to tree. But one time I was caught off guard by a branch breaking. I was lucky it was later in the spring and the new shoots at the bottom slowed my fall as I crashed down, coming out unharmed but wiser.

20. Adelin being thrown off her bicycle and bitten in the leg by the neighbour's dog. Off she went to the doctor for a tetanus shot. Dad had never shouted "go home" so loudly.

21. Rod giving us a "practice run" with proper table etiquette before his graduation dinner, to save him embarrassment from all these unruly brothers and sisters in front of his educated friends.

22. Norbert in Morocco not realizing that the postal strike in Italy was not allowing his letters to get home. How much weight did Dad lose in these five months in 1969 when Norbert was in Europe and North Africa?

23. By the way Dad, did you know that the old station wagon could actually do $110 \mathrm{mph}$. Norbert, Fred and Honory all testify to it. And you said the most it could do was $65 \mathrm{mph}$.

24. At around age 8, Jeanette remembers wanting to know what was inside a 22-gun shell: I took a bullet from the closet in the sewing/washing machine room then went and got a hammer from the shop. On our front step, I sat facing the wall smashing the bullet with the hammer. It would flip and bounce around during each hit. Then finally it went off with a bang somehow avoiding shooting me or the two corners of the house. I was stunned, and my ears rang for the rest of the day. I don't think I told Mom until I was in my 20's!

25. Pat sent a similar story about exploring the inside of a 22-gun shell: I was 12 or 13 and Jeanette was 6 or 7 . I was taking hunter safety and loved shooting things I was allowed to shoot like gofers, blackbirds and crows. I was excited to share my new-found knowledge with my little sister. Dad had a "junk drawer" in the entrance to the house and there was always some 22shells and shotgun shells in there. I showed Jeanette that a 22-shell was a rim fire (the hammer 
hits a spot in the rear rim of the shell to ignite it), while a shotgun shell is a centre fire shell (the hammer hits the centre of the shell to fire it. Later that day, Mom or Dad or both heard a very loud bang on our front step. They ran to find Jeanette crying with a hammer in her hand and an exploded shotgun shell on the step. They asked her what she was doing, and she cried that I told her to do it! Needless to say, I was in deep shit. Thank God she wasn't hurt. I learned a costly lesson on what new knowledge to share with whom.

26. When Doreen started school, Mom asked her what she wanted in her thermos. She replied without a moment's hesitation, "beer". Her request was denied. We had always enjoyed having a sip of Dad's beer on Sunday afternoons. Mom became less strict as the years rolled by because Jeanette was given a vodka drink in her thermos on her last day of school at the end of Grade 12 ! Celebrating the end of 30 years of making school lunches.

27. Adelin having a bike crash in New Zealand as her brakes failed in a heavy rainfall. Luckily, she was going down a driveway, flying over a set of steps, through some trees into a fence. Knocking on the neighbour's door, soaking wet, she asked for help to find her glasses in the grass. Result: a badly bent front wheel!

The public part of the $40^{\text {th }}$ Anniversary was celebrated with a mass at Saint Hubert and a dance at the Whitewood Hall. All Canadian cousins were invited, along with friends and neighbours from Saint Hubert, Langbank and Whitewood. Dorothy wore her wedding dress as did most of her daughters and daughters-in-law. When the children were purchasing soft drinks for the dance, the grocery store in Whitewood said we could settle-up once we had returned the unused bottles. The Beaujot name was a sufficient deposit!

At the Whitewood Hall, each of the children spoke on some aspect of their parents' lives. Focusing on the early years of their marriage, Fred told stories of the mouse scaring his parents in the middle of the night by running across the piano keyboard, and of his Dad at the Regina Exhibition trying to make a fast fortune by gambling with the money they had saved to buy used furniture. Fred continued by saying: I asked various people to help me on this, but the stories told by Uncle Mike were all censored, and those of Aunt Flora were too innocent to be believable.

But the best story comes from an old farmer that I just met this week. It happened on their honeymoon. This farmer had lost his bull and was searching all over the countryside for it. He had looked all over all day and finally at night he was too far away from home to go back, so he went to the motel in the closest town. It was almost full, but he got a room and checked in. When he saw himself in the mirror, he realized how dirty he was. He didn't want to sleep on the clean bed, so he crawled up behind the bed and went to sleep. Later that night, Mom and Dad decided to stop for the night at this motel. They went to check in and the clerk had forgotten about the old farmer and put them in the same room. Anyway, to keep things short, the farmer woke up after it was too late to interrupt so he stayed there quietly hoping not to be noticed. When things started to get romantic, Mom looked into Dad's eyes and said: "I can see the whole world in your eyes". At that point, the farmer jumped up and said, "Can you see my bull?" 
Fred finished by saying: It took a lot of hard work to get by in those days. I think the reason things are better for us is because of the efforts made by people like Mom and Dad to make things better for the next generation.

Doreen started by giving special thanks for all the school lunches. She estimated that Mom and Dad had made 19,680 school lunches over 30 years. Jeanette's last lunch was to be special, so Mom topped it off with some "Hawaiian Slush" in the thermos. It wasn't until Jeanette had left that Mom remembered that there was vodka in that slush. Doreen continued:

Mom and Dad still enjoy visiting friends and relatives as much as they ever did, maybe even more now that Dad doesn't have to carry us sleeping kids into the house and up to our beds after a late night of playing cards with neighbours. I don't think you knew this, Dad, but many times I was just pretending to be sleeping just to get that ride up the stairs.

Dean and I feel very fortunate to be living so close to Mom and Dad. We have relied on them many times like the time when Grant was just five days old. Dean phoned Dad at 2:00 am for them to help us out by watching the kids while we took Tedd to Kipling for stitches after he had fallen out of bed. Dad drove us to Kipling and Mom stayed with the kids. When we got back at 4:00, the dishes were washed, the floors swept, all the toys put away, and the kids were all still sleeping, even 5-day-old Grant.

Roderic spoke of the extended family and the diversity brought by marriage. Just looking at the names already shows much diversity:

The brothers and sisters of Dad and Mom married families with the names of Driscoll and Beaulac on the Beaujot side, and Laforge, Leconte and Smeets on the Mullie side.

Through the nephews and nieces of Mom and Dad, we have links to families with names of Holmes, Cudmore, McLelland, Warner, Wood and Jordens on the Driscoll side; Douglas, Gerwing, Hack and Pulvermacher on the Laforge side ${ }^{39}$; Hameluck, Haste, Boyko, Heywood, Katuski and Wittebolle on the Raymond Mullie side ${ }^{40}$; and Morrison, Watson and Gunn on the Michel Mullie side. Hardly a French sounding name among them.

Seven of my parents' children are now married, with the names of Vandermeer, Mitchell, Korpela, Stella, Fry, Gardner and Ede, which bring ethnic origins including Scottish, English, Irish, Finnish, Swedish, French, Italian, Dutch and German ${ }^{41}$.

Norbert spoke of enduring community relationships:

Those of us who live in larger centres look with envy at the support that comes from relations over generations, fostered in smaller communities.

For 40 years and more, you have felt the same joys and the same sorrows, you have shared the same crop failures and the same successes, you have watched and aided in the growth and development of each other's children and shed a common tear over the death of a friend.

\footnotetext{
39 In 1987 and 1988, the name Stephens and Banks would be added.

40 In 1994 the name Laidlaw would be added.

${ }^{41}$ In 1993, the names Warje and Wooff would be added, in 2000 and 2015 Dean and Paslawski, adding Ukrainian to the list of ethnic origins.
} 
We are happy to see Dad and Mom amongst their friends and we can see they have been shaped through the give-and-take relation with a stable community over many years.

Thanks for being there for us!

Honory spoke of how Dad and Mom were so supportive of education ${ }^{42}$. While there was always "real work" to do on the farm, homework came first. Money was in short supply, with surpluses reinvested in the farm. But our parents saw real value in investments in education. If it was for education, money could always be found.

Pat talked about accomplishments in farming. Observing that farming is only rewarding to those who make it a lifelong commitment, Pat spoke of how Mom and Dad kept up with the changes needed to make a success of farming:

Mom and Dad got off to a good start, Dad married the daughter of a wealthy seed grower, good move Dad! The first year Dad was still in the army. He got a leave in the spring to put the crop in, but it was an early spring and when he got home Mom already had the crop in the ground. Ever since, they have worked together in operating the farm.

In 1948 , they got rid of the team of 8 horses and bought a new Oliver 70 for $\$ 1350.00$. They bought one of the first sprayers in the area to spray 2-4D on their crops and for neighbours. In 1951 they bought a combine and auger and were no longer dependent on custom threshing. With their 32-volt electrical system, they set up a small seed cleaning plant. At that time, it was very much a mixed farm, with cattle, chickens, pigs, horses, ... and children.

Expanding from the half section that they started with, by 1968 they were farming seven quarters, a large farm at the time. Shortly after this expansion, they decided to get out of the cattle business and to specialize in grain farming. This allowed them to invest in the improved technology that was suitable to maximizing grain production. With the cattle gone, they were also able to educate themselves in all the new chemicals, seed varieties and fertilizer applications that were becoming available. They also became knowledgeable in the technologies of continuous cropping and soil preservation. They seeded every acre possible, using good varieties of grain on clean and fertile fields.

On the topic of geography and travels, Adelin spoke of Mom and Dad's love for travelling, which has instilled in us the seed of caring for the whole earth, full of uniquely interesting people and places:

As a teenager, there was Dad's great bicycle trip from Amsterdam, north of Yorkton, to Handsworth and back, for a total distance of over $500 \mathrm{~km}$.

Our family always enjoyed the trips, every other year, to Arborfield where we had wild and wonderful times with our cousins. In 1963 there was the Black Hills of South Dakota, where the boys got lost in the hills, then in 1965 to British Columbia where we couldn't find any mountains until the fog lifted after our first night of camping, and in 1967 it was Expo67 in Montreal and a rainy visit to the Plains of Abraham in Quebec City. All of these travels were camping trips with six or seven children, if you can imagine, ... mosquitoes and all!

\footnotetext{
${ }^{42}$ Honory's text is not available.
} 
During the winter of 1975-76, Mom and Dad made their first trip to France, Belgium and six other countries in Europe. In 1982, it was Argentina, with Jeanette representing the rest of us, for Honory and Deanna's wedding. An awesome trip with one of the plane's engine's giving way high over the Atlantic.

Adelin went on to list the travels of the children, bringing them to all continents except Asia: Pat doing custom combining in the United States, herself to Hawaii, Fiji, New Zealand and Australia, Leona and Russell to Colorado, Europe and Hawaii, Honory to Argentina, various places in South America, Sweden, Finland, and wherever there are pipelines, Fred and Karen to sun holidays in the Caribbean, Norbert to Morocco, returning so tanned that someone thought he was an Arab in-law at Mom and Dad's $25^{\text {th }}$ Anniversary, Rod and Liz to North Africa, and Doreen and Dean to Kenosee Lake ... and Toronto.

Jeanette presented a gift on behalf of her sisters and brothers:

As a symbol of our appreciation, we are giving you a satellite dish, so that you can catch all the TV channels up in the sky. We are cementing the dish into the ground behind the house, to secure your anchorage on the farm. Now, this must in no way interfere with your many trips and visits.

There have been many changes over the past 40 years, from horse and buggy days to satellites 23,000 miles in the sky. The one thing that has never changed is your love and affection to everyone that comes your way. Many happy hours to you both.

Leona concluded the program with a toast:

As I was thinking of what I could say about Mom and Dad, the thing that kept coming back to me was their spirit of giving. To me this characterizes them very well. You have all heard the saying, "As you sow so shall you reap." And if you look around and see all the friends around Dad and Mom, it is obvious that they weren't only sowing grain all these years, they were sowing seeds of friendship ... and here is the abundant harvest!

Another thing about Mom and Dad is that they are two of the greatest teachers around ... teaching by example. They not only set an example for their immediate family, but also for their community, the church and the school. Everyone was richer for what they offered.

So, as we conclude, I would like to propose a toast to Dad and Mom, not so much for all the beautiful things of the past and what they have offered in the past, but more so for the rich opportunity of the future. If the past is an indication of what the future holds, there are many rich blessings to come. I, along with my brothers and sisters, propose a toast ... to new beginnings.

Concluding with the Special Intentions at the Saint Hubert Eucharistic Celebration: On this day when we celebrate Leon and Dorothy Beaujot's $40^{\text {th }}$ Anniversary of marriage, let us pray that we are all able to gain strength from witnessing such enduring relationships.

As we celebrate at Saint Hubert we give thanks for the special spirit of this community. We give thanks for families, those that are here and those that we cherish in our hearts. As a farming community where we recognize through the weather a special dependence on God, let us pray for rain and good growing conditions. 


\section{Appendix 6.1}

Tables derived from farm account books of Leon and Dorothy Beaujot, 1943-1977

\section{Table 6.1 Notable purchases for home and farm, 1943-58}

1943: Wagon at sale of Leon's parents, $\$ 43$

1944: Rake at sale of Leon's parents, \$12

1944: Drill and binder at sale of Leon's parents, $\$ 200$

1944: Cultivator at Praud sale, $\$ 20$

1945: Two quarters (W $1 / 2$ of 19-14-3) from Fred Elkington, $\$ 7,275$

1945: Harrows and cart at Miles sale, \$16

1945: Sleigh at Co-op, $\$ 60$

1945: Dining room table, 9 chairs and dresser, Regina, $\$ 54$

1945: Kitchen stove, Regina, \$54

1945, China Cabinet, Regina, $\$ 38$

1946: Wood water pump at Eaton's, \$25

1946: Viga cream separator at Eaton's, \$26

1947: Warm Morning Heater, United Grain Growers, \$77

1947: Cockshut 15 foot swather, $\$ 450$

1947: Model A used car, $\$ 200$

1948: Oliver 70 tractor, $\$ 1350$

1948: Co-op Weed sprayer, $\$ 220$

1948: 38 gallons of 2/4D, $\$ 418$

1948: 32-volt system: $\$ 300$ including shipping, plus $\$ 95$ to wire house and barn

1949: 38 gallons of 2/4D, $\$ 418$

1949: 1948 Dodge car, $\$ 2050+$ trade-in of Model A

1950: 10 -foot cultivator, $\$ 300$

1951: Massey Harris Viking Fanning Mill, \$128

1951: CCIL disker, 12 feet, $\$ 553$

1951: Cockshut tractor, $\$ 2,350$ (-\$1350 trade-in of Oliver tractor)

1951: Rod weeder and harrows, Dovall sale, \$157

1951: Oliver combine No. 15, pull-type, $\$ 1700$

1951: Grain auger and hopper, \$257.

1952: 1942 truck, $\$ 575$

1952: House extension, material and labour, $\$ 4,042$

1954: Saskatchewan Power, $\$ 480$ for yard post and to get hooked up

1956: Deep freezer, St. Hubert Co-op, $\$ 340$

1957: Welder, final payment of $\$ 250$

1957: Pressure system, $\$ 130$

1958: Drill, $\$ 180$ at sale south of Kennedy (April 1958)

Source: Leon and Dorothy Beaujot, farm account books, 1945-48 and 1949-59 


\begin{tabular}{|c|c|c|c|c|c|c|c|c|c|}
\hline \multicolumn{10}{|c|}{ Table 6.2 Total income by source and total expenses, $1945-1959$} \\
\hline Year & Expenses & Income & $\begin{array}{c}\text { Non- } \\
\text { Farm } \\
\text { Income }\end{array}$ & $\begin{array}{c}\text { Farm } \\
\text { Income }\end{array}$ & Grain & $\begin{array}{l}\text { Custom } \\
\text { Work }\end{array}$ & Livestock & Cream & Poultry \\
\hline 1945 & 879 & 1,488 & & & & & & & \\
\hline 1946 & 1,811 & 1,826 & 192 & 1,635 & 1,278 & 139 & 206 & - & 12 \\
\hline 1947 & 4,062 & 4,826 & 1,260 & 3,572 & 1,966 & 478 & 1,023 & 37 & 68 \\
\hline 1948 & 5,379 & 3,804 & 1,552 & 2,258 & 981 & 148 & 846 & 134 & 149 \\
\hline 1949 & 7,768 & 8,564 & 2,883 & 5,681 & 3,605 & 893 & 1,014 & 84 & 85 \\
\hline 1950 & 3,885 & 4,050 & 465 & 3,586 & 1,076 & 1,159 & 1,313 & 38 & - \\
\hline 1951 & 8,752 & 9,559 & 2,422 & 7,137 & 4,508 & 345 & 2,284 & - & - \\
\hline 1952 & 7,485 & 6,540 & 326 & 6,215 & 4,783 & 68 & 1,364 & - & - \\
\hline 1953 & 3,990 & 7,364 & 312 & 7,053 & 6,274 & 150 & 629 & - & - \\
\hline 1954 & 3,460 & 3,345 & 918 & 2,427 & 2,255 & 125 & 47 & - & - \\
\hline 1955 & 3,117 & 3,043 & 987 & 2,056 & 1,907 & 60 & 89 & - & - \\
\hline 1956 & 3,853 & 5,631 & 735 & 4,895 & 4,604 & 32 & 259 & - & - \\
\hline 1957 & & 6,061 & 539 & 5,533 & 4,876 & 236 & 421 & - & - \\
\hline 1958 & & 2,636 & 552 & 2,084 & 1,050 & 23 & 983 & - & 28 \\
\hline 1959 & 4,905 & 3,189 & 616 & 2,573 & 2,348 & - & - & 225 & - \\
\hline \multicolumn{10}{|c|}{$\begin{array}{l}\text { Source: Leon and Dorothy Beaujot, Farm Account Books } \\
\text { Notes: (1) Non-farm income includes transfers and Family Allowance. (2) Farm income does } \\
\text { not show trade-in income from sale of machinery at purchase of new machinery; expenses } \\
\text { are net of trade-in. (3) Land purchases not included.(4) Custom work includes "other". (5) } \\
\text { All figures are Canadian Dollars for the year shown without adjustments for inflation: } \$ 1.00 \\
\text { in } 1945 \text { would be } \$ 14.84 \text { in } 2019 ; \$ 1.00 \text { in } 1955 \text { would be } \$ 9.48 \text { in } 2019 \text { (see } \\
\text { Bankofcanada.ca inflation calculator). }\end{array}$} \\
\hline
\end{tabular}




\section{Table 6.3 Major purchases: land and machinery, 1959-1977}

1959: Two quarters (W 1/2 33-13-3) from Camille Dumonceaux, $\$ 8000$.

1959: CCIL disker, Cockshut HD cultivator and Model D John Deere tractor, $\$ 1200$

1960: Third quarter (SE 1/4 33-13-3) from Camille Dumonceaux, $\$ 4000$

1960: Minneapolis Moline 5 Star tractor, $\$ 4600$

1960: Minneapolis Moline combine, pull-type, $\$ 3500$

1961: 1952 International 3-ton truck, $\$ 1300$

1961,1957 Ford station wagon car, $\$ 1500$

1962: Moved house, $\$ 1600$ including new basement

1962: Half share (with Gabriel Decelle) International No. 46 baler, $\$ 750$

1962: Half share (with Gabriel Decelle) side delivery rake, \$225

1963: 1958 Ford half-ton truck, \$700

1964: Massey Harris disker, 15 feet, $\$ 2800$

1964: Massey Harris swather, 16 feet, $\$ 1500$

1965, Chisel plough, $\$ 950$

1965: Massey Furguson 1100 tractor, $\$ 10,025$ (-\$4475 trade-in)

1965: Massey Furguson 405 pull-type combine, $\$ 7,625$ (-\$3525 trade-in)

1965: SP swather, $\$ 2,600$ ( $\$ 1600$ trade-in)

1967: Glencoe Cultivator, $\$ 1795$

1967: Two 12-foot diskers, $\$ 5975$ (-2975 trade-in)

1967: No. 35 Massey Furguson tractor, \$2200

1968: two quarters (W $1 / 2$ 4-14-3) purchased from Harry Adams, $\$ 21,750$

1971: Morris Chisel Plough, 25 feet, $\$ 2500$

1971: 6601 John Deere combine, $\$ 11,400$ (- $\$ 6,850$ trade-in)

1972: 1972 Half-Ton Dodge truck, $\$ 4700$ (-\$1700 trade-in)

1973: Morris Rod Weeder, $\$ 2,730$

1973: White 2270 tractor, $\$ 21,865$ (-10,965 trade-in)

1974: Yard tractor, $\$ 2,520$ ( $\$ 345$ trade-in)

1974: Farm grain storage building installed, $\$ 5,988$

1974: Grain dryer, $\$ 5,929$

1974: D-700 Dodge truck, $\$ 13,849$ (-\$6,848 trade-in on 1968 Int'| 1600)

1975: Alteen Disk, $\$ 5,700$

1975: John Deere 4020 tractor, $\$ 8,900(-\$ 1,900$ trade in on Oliver 70$)$

1976: Swather John Deere 800, $\$ 7,775$ (- $\$ 4,600$ trade-in)

1977: 7701 John Deere Combine, $\$ 28,500$ (-\$15,500 trade-in)

1977: Dodge 700 truck, $\$ 1,800$ (-\$1,100 trade-in)

1977: Massey Ferguson $30 \mathrm{ft}$ Diskers, $\$ 13,050$ (-\$6,050 trade-in)

Source: Leon and Dorothy Beaujot, farm account book for 1949-59 and Books for individual years 1960-77. Account books for 1978-86 not located. 
Table 6.4 Farm income from grain, custom work, livestock, cream, 1960-1977

\begin{tabular}{r|rrrr}
\hline Year & Grain & Custom Work & Livestock & Cream \\
\hline 1960 & 6,053 & 93 & - & 329 \\
1961 & 5,907 & 362 & 853 & 208 \\
1962 & 5,259 & 950 & 1,215 & 81 \\
1963 & 14,674 & 300 & 1,064 & - \\
1964 & 12,536 & 50 & 861 & - \\
1965 & 10,847 & - & 2,566 & - \\
1966 & 19,809 & - & 3,247 & - \\
1967 & 15,828 & - & 6,328 & - \\
1968 & 12,936 & - & 8,707 & - \\
1969 & 14,616 & 172 & 7,959 & - \\
1970 & 13,306 & 106 & 7,942 & - \\
1971 & 21,461 & 404 & - & - \\
1972 & 31,120 & - & - & - \\
1973 & 40,921 & 154 & - & - \\
1974 & 48,900 & - & - & - \\
1975 & 74,495 & 25 & - & - \\
1976 & 65,448 & - & - & - \\
1977 & 70,030 & - & - & - \\
\hline
\end{tabular}

Source: Leon and Dorothy Beaujot, farm account books, 1960-77. Books for 1978-86 not available.

Note: All figures are Canadian Dollars for the year shown without adjustments for inflation: \$1.00 in 1965 would be \$8.05 in 2019; \$1.00 in 1975 would be \$4.84 in 2019 (see Bankofcanada.ca inflation calculator).

Table 6.5 Farm inventory and net worth, 1960, 1968 and 1977

\begin{tabular}{l|rrr}
\hline & 1960 & 1968 & 1977 \\
\hline Inventory & & & \\
Owned Land & 21,200 & 91,175 & 148,000 \\
Buildings and Improvements & 11,950 & 30,495 & 30,420 \\
Farm Machinery \& Equipment & 10,965 & 39,350 & 73,520 \\
Farm Produce on Hand & 8,495 & 14,020 & 74,500 \\
Farm Supplies on hand & 196 & 570 & 5,730 \\
Livestock & 4,000 & 4,150 & - \\
Net Worth & & & \\
Total Farm Assets (from above) & 56,806 & 179,760 & 332,170 \\
Total Farm Debt & 16,756 & 57,975 & 49,740 \\
Total Farm Equity & 40,050 & 121,785 & 282,430 \\
\hline
\end{tabular}

Sources: Leon and Dorothy Beaujot, farm account books for 1960, 1968 and 1977.

Notes: (1) Figures shown are for end of year. (2) Total land was 800 acres at 31 Dec 1960, 1,120 acres at 31 Dec 1968 and 31 Dec 1977. (3) All figures are Canadian Dollars for the year shown without adjustments for inflation: $\$ 1.00$ in 1960 would be $\$ 8.62$ in 2019; \$1.00 in 1968 would be \$7.22 in 2019; \$1.00 in 1977 would be \$4.15 in 2019 (see Bankofcanada.ca inflation calculator). 


\section{Chapter 7 \\ Retirement Years: Travel, Family, Reflections, 1986-2014}

As planned at Leon and Dorothy's $40^{\text {th }}$ Anniversary in 1985, their sons Norbert and Pat took over the farming operations in 1986, with the parents remaining on the farm. Their lot in Kipling was purchased in April 1989, with their retirement home built by Norbert over the following summer. In June 2010, a year after Leon's $90^{\text {th }}$ birthday celebrations, they moved to Victoria Park Personal Care Community, a private care home in Regina, but after ten months they moved back to a seniors' apartment, The Kipling Manor, at the end of February 2011, with Dorothy mostly at the Willowdale Kipling care home after midMay 2011. In mid-December 2011, they moved into Hill Top Manor in Weyburn, a private care home, where they remained until Dorothy's death on 6 March 2014 and Leon's death on 28 May 2014.

\section{The Kipling years: 1989-2010}

In 1986, Norbert and Pat purchased part of the farm and agreed to rent the remaining three quarter sections from their parents. ${ }^{1}$ The brothers also bought all the farm equipment over a five-year period. With arrangements through life insurance and their will, the remaining property was transferred to Norbert and Pat in 2014, with the other children receiving a larger share of the liquid assets in the inheritance. $^{2}$

Quoting Leon and Dorothy: When all were gathered on our $40^{\text {th }}$ anniversary, in 1985, we worked out an arrangement with Norbert and Pat taking over the farm and we were expecting to remain in the same house that we had since our marriage. The children bought us a satellite dish, so we could get numerous TV channels and see the world from our own living room on the farm, and they cemented this into the ground so that we would stay put. We nonetheless took advantage of our new liberty to do much travelling, and within a few years we decided to move to Kipling. We considered other towns, especially Whitewood, where many from the St. Hubert district were moving, but we preferred Kipling. When we found an ideal lot at the edge of town, and Norbert was willing to take on the construction of our new home, our decision was made.

The lot in Kipling was purchased on 6 April 1989, at 211 Louisa Ave. ${ }^{3}$ Leon continues: Norbert started the foundations for the house before we were back from our trip to Florida. Based on Dorothy's design, Norbert made blueprints for a one-story house. At 1708 sq. feet, the house was on one floor with three bedrooms, two bathrooms, kitchen, family room and living room. There was also an attached garage

\footnotetext{
${ }^{1}$ Pat purchased the north farm (West $1 / 2$ of 19-14-3) and the north part of the Harry Adams farm (NW $1 / 4$ of 4-14-3). Norbert and Sam already had a half section that they had purchased from the Victor Dumonceaux farm, and they purchased the south part of the Harry Adams farm (SW $1 / 4$ of 4-14-3) which included the yard site. Leon and Dorothy retained the Camille Dumonceaux farm (W 1/2 and SE $1 / 4$ of 33-13-3).

2 Pat's share was the SE quarter of 33-13-3 plus the land west of the creek on the west half of 33-13-3. Norbert's share was the main part of the west half of 33-13-3 (east of the creek).

${ }^{3}$ The title specifies a portion (most southerly 22.86 meters) of lot 6 , block 5, Kipling plan E 2016, value of $\$ 5,000.00$.
} 
and insulated sunroom and garden shed, on a lot measuring 75 feet by 117 feet. ${ }^{4}$ When they were no longer able to travel south for the winter, they especially enjoyed their insulated sunroom, which they called their "Florida room". In the flyer advertising the sale of the house in 2010, the front flower garden is shown, and the listing indicates: garden including producing strawberries.

Leon and Dorothy: The house was built with no cement foundation. It was on pillars that were first pounded into the ground to a depth of six feet. The construction started when there was still frost in the ground, so it took quite some work with the "pounder" that Brian Kent had designed. Our neighbour, Graham Shirkey, claimed that all the pounding had shook him right off the toilet seat. He repeated this story many times, but never pressed charges! And the house never moved.

Graham and Helen Shirkey were taking manure from their farm to their yard, and they gave us some as well, spreading it all around the new yard. This gave us excellent growing conditions for the garden, grass and flowers.

One of the things that we had left behind on the north farm in 1962 was the lovely grove of evergreen trees that we had planted to the north of the yard. They were planted in about 1952 because Roderic remembers his parents working hard at weeding the trees when they were first planted. When some of the trees were moved from the north farm, Allan Cross had helped us with his front-end loader, and various neighbours had come to help with tractors and racks, in exchange for getting two trees for themselves. The trees were transported on hay racks. After it had been moved, one of the tallest trees looked like it was going to come down in the wind at its new location on the south farm. As a temporary measure, we anchored the tree to the truck for the night. This was Halloween night and when Norbert came home, he thought his father had forgot to put the truck away, so he was starting to move it and he pulled the tree right out of the ground. We managed to get the tree back up and properly secured, and it is there to this day.

Once we were in Kipling, we moved nine evergreen trees to our new yard. Seven of the trees had grown as seedlings from the evergreens that had been moved from the north farm to our new yard on the south farm. Another two seedlings were descendants of the trees that Dorothy had planted with her father in the valley of the Mullie farm. These trees had burned down, but the pinecones produced new trees that further reproduced into the seedlings that we moved to our yard in Kipling. We got help from a mover in Indian Head to move these trees which already had a height of 15 to 20 feet.

At first, when we were living in Kipling, we helped on the farm with swathing and combining, but when the machines got too complicated, we quit. Now, with GPS, you no longer even need to drive the tractor, so we are not needed! Of course, we were always available to check the crops, even though farmers now employ professional inspectors to do the job.

\footnotetext{
${ }^{4}$ In the flyer advertising the sale of the house in 2010, the front flower garden is shown, and the listing indicates: garden including producing strawberries.
} 
During our first summer in Kipling, we spent many days taking down the fence at the north farm. That way Pat and Norbert could sow into the road allowance and take advantage of the rich "blow dirt" from the 30 s that had accumulated on the fence line.

We had a large garden of our own, and often put up vegetables and fruit from the gardens of our children when they had surpluses. Eventually, the garden got smaller as we do not eat as much vegetables and the evergreen trees are encroaching on the area. But there are always enough beans to freeze for the winter.

We also continue to collect berries in the wild. One time we went out with Graham and Helen Shirkey, and Boyd and Lydia Cross and came back with a whole truckload of chokecherries.

In their yard in Kipling, Dorothy also had lots of flowers, both in the front and back of the house. When the family was still on the north farm, Leona remembers asking her Mom to grow flowers in the garden. Mom gave her a package of seeds to grow on her own, but they never came up. Leona now thinks they may have been parsley seeds. In those early years, Mom did not have much time for flowers, but she really made up for it later. She was very fond of pansies, and she especially enjoyed having them re-seed themselves.

Leon and Dorothy continued to keep books on their income and expenses. In 2006 the rental income from the farm was $\$ 12,900$, the Old Age Security payments amounted to $\$ 11,675$, the Canada Pension Plan was $\$ 8,075$ and there was $\$ 3,133$ from Sun Life Annuities. The total income of $\$ 36,242$, along with savings in the bank account, was sufficient to cover expenses without touching their investments. ${ }^{5}$

They also volunteered to make deliveries for meals on wheels, and later Leon was certified to drive people to Regina for medical visits. The trips continued into his $90^{\text {th }}$ year, but by then he was only driving friends who needed to go to Regina. Leon continues: It is good that I learned to drive in cities. Many of my older neighbours are afraid to drive in cities like Regina.

By the end of their stay in Kipling, they were still driving on their own to Regina, but other services were coming to their home. In particular, Leon added: The Health Nurse comes two times per week.

\section{Travel}

Once they were no longer looking after the farm, Leon and Dorothy took advantage of their good health to travel. During his army days, Leon had travelled to the west coast as far as Prince Rupert and to Sussex, New Brunswick, on the east side of the country. For their honeymoon they had travelled to the Regina Exhibition, and again in January 1946 to get Leon's army discharge papers. The family would soon travel every second year to Arborfield, visiting the Mullie and Laforge families. In 1963 the family

\footnotetext{
${ }^{5}$ Black Columnar account book for 2006 and 2007 pp. 26-27.
} 
travelled to the Black Hills of South Dakota, the following year they went to British Columbia and in 1967 to Expo 67 in Montreal.

In 1976, they made their first trip to Europe, with Leon's sister Flora, taking a bus tour and visiting relatives on the Beaujot, Sénéchaud and Mullie sides. Altogether, they travelled in eight countries. They made a second trip to Europe in 1994, this time travelling with Joanne and Marg Jordens, including a bus trip to Scotland and a visit with their niece Annette and Andrew Gunn in England.

Reflecting on the first trip to Europe when they were visiting relatives, Dorothy continues: Travelling and visiting relatives, every day was like Christmas, they would always bring food. Leon always fills his plate, but this is only the first course, then he would take more, but there were a lot more courses. I remember this one place, someone brought out this huge tray, there was everything on it, yet we were not even hungry. For us it was too much because we were going from place to place. And that was when I could eat anything.

They also went to Argentina, for Honory and Deanna's wedding in November 1982 and again for Christmas 1995, to meet Melissa who was 18 months. On the first trip, Jeanette was with them and they also went to Iguazo Falls and to the farm of Eric and Cristina Lanthiez (near Rio de Janeiro, Brazil). On return from Rio in November 1982, one engine of the airplane gave out over the Atlantic and they had to spend a difficult night on the hard benches of the Miami airport.

They would eventually travel to all Canadian provinces except Newfoundland, and most American states, "except Hawaii and a few others". In their 1989 trip to Texas, they also did a bus trip into Mexico. Leon continues: Plus, we had time to do a fair amount of farming, gardening and neighbouring. When we were farming, our neighbours wondered how we were able to take two weeks off every year. We did not have as much hay to put up because we did not have much cattle. We travelled between the spraying and haying seasons. At the time of their $60^{\text {th }}$ Wedding Anniversary in 2005, after 20 years of retirement, Leon calculated that over these 60 years they had travelled some 1,350,000 miles in 14 cars (see Box 7.1).

\section{Box 7.1 Cars, trucks and miles}

We have owned 14 cars in 60 years (1945-2005), with only one of these that we did not sell back after usage. We calculate that we did some 1.4 million miles with these cars.

\begin{tabular}{lr} 
& Estimated m \\
Ford Model T & 2,000 \\
Ford Model A & 5,000 \\
Ford Model B & 20,000 \\
Dodge Sedan Deluxe & 150,000 \\
Ford car & 110,000 \\
Ford wagon & 150,000 \\
Dodge Furry & 100,000 \\
\hline
\end{tabular}




\begin{tabular}{|lc|}
\hline Ford Crown Vic & 125,000 \\
Ford Half-ton & 200,000 \\
Dodge van & 150,000 \\
Nissan van & 125,000 \\
Subaru Forester & 100,000 \\
Subaru Outback & 110,000 \\
Nissan SUV Trail & 67,000 to year 2005 \\
& \\
We also had five trucks, starting with three older used two-ton trucks. We bought a new three- ton \\
International and paid with grain that we hauled to Midale, SK. We traded this truck for a new three-ton \\
Dodge 1967, with a 300-bushel pup trailer, paying a difference of \$4,900. This truck is still in use, having \\
been renamed the Silver Bullet.
\end{tabular}

In 1986, they bought a fifth-wheel camper and travelled extensively in Canada and the United States. They would typically travel to Ontario in the fall, visiting their sons Roderic and Fred, then continue to Florida. In the spring, they would go to the West, visiting their daughters Adelin and Leona in British Columbia, with a stop in Calgary to visit Honory and his family. This brought them to see the spring flowers in $\mathrm{BC}$ when there was still snow on the ground in Saskatchewan, and the fall colours in the trees of Southern Ontario. The distance to 100 Mile House, BC, via Abbotsford was 2,200 km. The shortest route to London, Ontario, was via the United States, a with a first night at Grand Forks Minnesota, then a third night after the Mackinac bridge, for a total of 2,500 km to Toronto, and another 2,100 km to Orlando.

Dorothy kept a Trip Diary ${ }^{6}$, where we see that in their first trip to Florida, they left on 6 October 1986, stopping in London (Ontario), Toronto and Montreal (visiting Dorothy's cousins Joe and Tillie Mullie and Gilbert and Ruth Mullie), then to the Maritimes, New York, spending an extensive time including Christmas in Florida, where they especially enjoyed the out-door pageants, and getting back home on 14 February 1987.

Dorothy and Leon continue: On Halloween we started down the coast of Nova Scotia toward Florida. At a rest area, we got talking to a lady who was walking her dog. We could not understand a sign about garbage, and she helped us figure out that "oh, yes, local people were not allowed to put garbage here, but it was fine for travelers." She said they were from Nova Scotia and on their way the Woodland Camp in Florida. We took directions from her husband, and they set off toward their destination. We followed them a few days later, and as we turned into Woodland, going down a narrow drive, the first people we saw were the people from Nova Scotia. It turned out that this Woodland Lutheran Camp, close to Orlando, Florida, was ideal for us $^{7}$. We went there several winters, made good friends, and some of our children and grandchildren would eventually come to visit.

\footnotetext{
${ }^{6}$ This small green booklet called Trip Diary, shows detailed accounts of costs and places visited, including campgrounds, for 6 October 1986 to 9 June 1989.

${ }^{7}$ Woodlands Lutheran Camp no longer exists. The address was Box 137AA Winter Garden, Route 2, Florida 32787.
} 
Leon recalled another incident from their 1986 trip: We got a frantic call from Norbert as he needed to know where to find the manual for the combine. While harvesting the small patch of land between the dam and the road, he had turned too short and the power-take-off between tractor and combine had come apart, badly wrapping up the wires controlling the combine. He needed the book to see how to reconnect the wires.

Always at ease in meeting people, Leon and Dorothy joined in with the various activities at Woodland. They continue: There were not very many Canadians there, especially from home, which was good because it brought us to make many new friends. Someone started an exercise club; at first there were two or three people but after a few days the whole place was full, with people staying after to visit. Having learned the routine, Dorothy started a similar exercise club when they were back in Kipling.

Their second trip with the $5^{\text {th }}$ wheel was in 1987. They travelled north from Edmonton, into the Northwest Territories, Yukon and Alaska, coming back along the west coast and through Calgary. They were travelling for six weeks, leaving on 9 June and getting back home on 20 July. On 21 June they were close to Inuvik (4,132 km from Kipling) for the longest day of the year, with the sun in the sky for the full 24 hours. The Trip Diary also shows a visit with Dorothy's brother Mike and Jeanne Mullie in Arborfield on 9-10 June, and with Leon's sister Flora Driscoll and brother Albert Beaujot in Calgary on 17-18 July.

The Trip Diary shows the second trip to Florida, starting in January 1988. There is an entry on 24 January showing that they picked up Dorothy's brother, Mike and Jeanne Mullie at the Tampa airport. Then, on 21 February, their son Rod and Liz and family arrived at noon. In the next five days the diary lists: Magic Kingdom, Cypress Gardens, horseback riding, swimming and E.P.C.O.T with nighttime illumination. Leon and Dorothy were back home in Saskatchewan on 11 April 1988.

For the third trip to the south, they left on 11 January 1989, this time going to Brownsville, Texas, and Mesa, Arizona, where others from Saskatchewan were spending the winter, including Leon's cousin, John and Shirley Pirlot. They were back home on 9 March. This was the year that their house in Kipling was being built.

They spent eight winters at the Woodland Lutheran Campground in Florida. Leon continues: After about five trips to Woodland with the $5^{\text {th }}$ wheel, we later went just by car, renting a trailer that was available because the owners could not make it that year. On our last trip in 1997, we took the train, leaving from Minot, North Dakota. This was a great deal at $\$ 1300$ return for the two of us, including all meals for the three-day trip to Florida. Over the years, we spent a lot of time with a couple who worked at Disney World. They always asked us to come along to see the sights. We would go with various people to Grand Field at Dunedin where the Toronto Blue Jays had their winter camp. Leon had always been a big fan of baseball, and in later life of the Blue Jays.

Reflecting on all this travel, Leon says: We had a few close calls on the roads, but not a scratch on the vehicles. On one occasion, with the $5^{\text {th }}$ wheel behind, we came to a corner where the vehicle ahead made a very sudden stop. I knew that I could not stop in time, so I just took the turn lane to the right 
and went around the corner instead. Dorothy was preparing our meal in the $5^{\text {th }}$ wheel and she did not even notice that we had made an unintended turn.

At the time of his $90^{\text {th }}$ in 2009 , Leon observed that, because of Dorothy's digestive system, we can no longer travel these kinds of distances. It would have been too hard on her to go to our granddaughter Camille's funeral in June 2005. We had a bad trip to Calgary, so I also went alone to Bertha's funeral in September 2008.

In 2002, they made their last trip to Ontario. As they arrived in London from Toronto, Leon's shirt was completely wet from the anxious stop-and-go traffic along the 401. Their last trip to BC was in March or April of 2005. They were so glad to have made this trip, when Dorothy was 87 and Leon 85, because it was the last time they saw Camille. She had driven to Abbotsford from Kelowna, and Leona and Russell had come from 100 Mile House. Adelin: we were nine of us for this last joyous gathering among the spring flowers of the lower mainland.

\section{Incidents in the air and on the water:}

While winter storm could make car travel treacherous, it was incidents in the air and on water that were most remembered. Leon and Dorothy continue: On the return from our first trip to Argentina, we were on a flight from Rio to New York that would then transfer to Winnipeg where we had left our car. After three hours in the air from Rio we could hear much excited talking among those speaking Spanish. The person sitting beside Jeanette asked if we had understood the message, saying that one of the engines of the airplane had stopped and we were had to land in Miami.

That was quite an ordeal, especially since we had to wait forever at the Miami airport for a new flight, which took us to Toronto instead. We could not get any sleep at the airport as there was no place to lie down. We were still in Miami at the time that Pat Smeets (sister to Arsene Smeets) was to come out with our car to meet us at the Winnipeg the airport. Leon asked desperately for help to notify Pat Smeets and the airline said we could call anywhere we wanted. Pat got quite a surprise when the message came over the PA that she was wanted on the telephone. We then telephoned Fred in Toronto to be able to spend a night there before finally going on to the last leg of our trip.

The scariest incidence was on water. During their second trip to Florida, a couple from the Woodlands camp had bought a passage on a cruise ship called the Sea Escape that was to start at Port Canaveral and come back to Tampa after four days.

Leon and Dorothy continue: On 14 March we toured Cozumel Island then we were back on the boat for the night, with the boat cruising northward. We were six hours out when a fire broke out in the engine room of the boat. We were at a performance on the cruise and at first we thought the smoke was part of the performance. We realized that was not the case when they told everyone that we had to immediately assemble on deck. We were eventually to spend 48 hours huddled on the deck in rough waters, unable to get to our cabins, with announcements saying that the situation was very serious. 
The crew were doing their best, but it seemed to take forever before we had life jackets on, and the attempts to lower the life boats were unsuccessful because the waves were too high. Since we were taking the place of another couple, one of the other passengers noticed that our names were not being called in the frequent roll calls. Very few people knew where we were, and our children were completely unaware of our situation. The children were following the news on the dire situation of this cruise ship, but they had no idea that their parents were on board. The news had shown two passengers air-lifted off the ship, one with a heart attack.

Dorothy's Trip Diary gives the basics, as follows:

13 March 1988: Leaving for 4-day cruise on the "Sea Escape"

14 March:

15 March: Cozumel Island-show and shopping, fire that night

16 March: Mexican tow boat, two passengers air-lifted

17 March: Arrived in Cancun Mexico, just getting dark. Took the plane to Tampa and arrived at Woodlands at 2 am.

A boat in the vicinity came to assist but the waters were too rough and there was danger of the two boats colliding. Another boat came and sprayed water, which was very good, but the fire started again, and we now had much water swishing aboard. There was no electricity and the washrooms were in particularly ugly condition. A man was stuck in the bathroom with no lights and he could not find the door, he yelled for help, and later could not stop laughing.

It took several hours to get a tow boat out. We were in Mexican waters and thus it had to be a Mexican tow boat. The first boat that was sent was too small and it could not manage to hook onto our boat.

We were in the dark, with water on the floor, a terrible stink in the bathrooms. The men could do it over the side of the boat, but the women had to use the bathrooms. There was lots of cold food and beer, but the bathrooms did not work. We spent two nights outside. They eventually got us to Cancun on little boats, 10 people per trip, about 150 passengers and $40 \mathrm{crew}$. They could only take a few at a time.

We were offered a free cruise or our money back. We took the money. We certainly did not want to have another cruise. When we hear of people planning a cruise we don't tell them this story so as not to frighten them. But it was very frightening, the crew did their best and were very good, but they also informed us that the situation was very dangerous, and we had to stay on deck ready to evacuate, except for going to the bathroom. We found out later that the same boat from the cruise ship changed name and sunk in Scandinavia as a ferry boat.

\section{Family: Weddings, Anniversaries and Reunions}

The year they moved into their retirement home in Kipling was the year that Leon was 70 and Dorothy 72. At this time, in 1989, their children were aged 24 to 43, and they had 15 grandchildren aged 3 to 16. 
By now they had attended the marriages of seven of their children: Norbert and Sam (née Dolores Mitchell) Beaujot in Moose Jaw on 24 July 1971; Doreen (née Beaujot) and Dean Gardner in Saint Hubert on 14 July 1973; Fred and Karen (née Korpela) Beaujot in Thunder Bay on 11 May 1974; Rod and Liz (née Elisabeth van der Meer) Beaujot in Edmonton on 13 July 1974; Leona (née Beaujot) and Russell Fry in Calgary on 4 April 1982; Honory and Deanna (née Stella) Beaujot in Buenos Aires on 6 November 1982; and Jeanette (née Beaujot) and Ken Ede in Whitewood on 27 October 1984. In the next four years, they would attend two more marriages of their children: Pat Beaujot and Judy Wooff in Swift Current on 3 April 1993; and Adelin Beaujot and Larz Warje in Abbotsford on 31 July 1993. Later, there would be two separations with Jeanette Beaujot partnering with Brian Dean in 2000, and the marriage of Pat and Charlotte (née Paslawski) Beaujot in Kipling on 14 February 2015.

Leon and Dorothy would also attend the marriages of their grandchildren: JoAnne Gardner and Glen Hoffman in Kennedy on 18 July 1998; Michael Gardner and Shelley Lewchuk in Yorkton on 29 July 2000; Rochelle Beaujot and Owen Kinch in Pense on 12 July 2008. They were not well enough to attend the wedding of Jessica Beaujot and Clarke Ellis on 7 August 2010 in Banff, Alberta. Later, among their grandchildren there would be the marriages of Grant Gardner and Ashley Gerstmar (Saskatoon, 28 May 2016); JoAnne Gardner and Chris McFadden (Kenosee Lake, 29 July 2017); Tedd Gardner and Viona Johnston (Saskatoon, 7 October 2017); and Brett Ede and Amanda Gibbs (Huatulco, Mexico, 15 March 2017); and the cohabiting unions of Cory Beaujot and Joey Tremblay (15 February 2004); Natalie Beaujot and Joel Williams (Margaret River, Australia, 2008); Mark Ede and Mandy Melanson (Kipling, 2011); Michelle Beaujot and Adam Patterson (Calgary, 1 January 2017); and Kira Warje and Jerrod Unrah (Abbotsford, 15 October 2018).

In 2010, when they left their home in Kipling, Dorothy and Leon had both celebrated their $90^{\text {th }}$ Anniversaries, their children were aged 45 to 64 , all married, all their 20 grandchildren had been born, now aged 12 to 37 , and they had 5 great-grandchildren aged 4 to 18 .

During these 20 years of their living in Kipling, there had been many marriages, anniversaries and deaths that brought Leon and Dorothy in contact with their immediate and extended family. Whenever they travelled, they made a point of visiting family and relatives on route: Mullie, Laforge, Beaujot, Driscoll, Payot, Pirlot, Gatin. They especially kept in contact with their 27 nephews and nieces (19 on Dorothy's side and 8 on Leon's side).

\section{0 ${ }^{\text {th }}$ Anniversary of Leon and Dorothy: Round Lake, Qu'Appelle Valley, SK, 7-9 July 1995}

With friends and extended family, Leon and Dorothy celebrated their $50^{\text {th }}$ Wedding Anniversary at a children's camp called Camp O'Neill, on Round Lake in the Qu'Appelle Valley, 35 km north of Whitewood. Many brought tents, trailers and motor homes to add to the cabins available on site. The total in attendance rose to $\mathbf{2 0 0}$ for the afternoon tea. There were ball games and various adventures on land and water. The beautiful weather made for a lovely gathering, under the trees, for Sunday Mass. 
The anniversary celebrations were true to a couple who never missed an opportunity to visit with neighbours and family members, near and far.

Their children had come from Langbank, Kennedy, Vancouver, 100 Mile House, London, Toronto and Argentina. Nephews and nieces had come from Calgary, Kamloops, Flin Flon, Gimli, Regina, Weyburn, Rouleau, Prince Albert, Aylsham, Nipawin, Arborfield, Bruno, Gillam, Rouleau, Saskatoon and St. Hubert. Dorothy's brothers, Mike and Jeanne Mullie and Raymond and Maria Mullie had come from Nipawin and St. Hubert, along with their first cousins from Arborfield (Roland and Mary Mullie) and France (Bernard Mullie). Leon's first cousin, Bernadette Gatin had come from Whitewood, along with several of her children, nephews and nieces on the Gatin side. Leon's teacher in Handsworth, Ann Gray, was present along with two others of her students: Bill Little of Windthorst and Graham Shirkey of Kipling. Friends had come from St. Hubert, Langbank, Whitewood, Kennedy and Kipling.

Several people spoke during the Saturday evening banquet. As MCs, Leona and Norbert had the theme of "nine lives," with accounts of experimenting with the laws of physics, chemistry, engineering, and even ballistics (before the firearm registry). Jack Driscoll's theme was the shy Beaujot children staying close to their mother, compared to the bold Driscoll clan who disrupted family gatherings. Pat and Fred, with help from Doreen and Jeanette, presented a slide show of memorable photographs. The biggest laugh came when the picture of three proud fathers with their first-born was followed by the same 1948 Dodge submerged under countless young first cousins. Then there was a sequence of pictures of the family home, from a "basic fixer-up'er" to the latest in "sponge painting with stucco".

\section{Box 7.2 Dorothy Beaujot: Did I tell you about our grandchildren}

As we gathered on Sunday morning around picnic tables at Round Lake, on 9 July 1995, Dorothy Beaujot said a few words about each of her 20 grandchildren, from the oldest to the youngest.

We were crowding in the van when Michael's little sister accidentally put her elbow in his eye. As he was crying, his Dad tried to comfort him saying, "Look, Michael, think of how much worse it would be if it had been my elbow." "Yike," he said, "I'd be in the hospital and you'd be in jail."

Big secret between Cory and his Dad, they were buying a corn-popper for Mother's Day. However, Mom was going through the catalogue one day and said: "I'm going to buy myself a corn-popper." "No, no," Cory exclaimed, ... realizing he was in a bind he added, "It's too much money."

We had JoAnn's hair shampooed and nicely set and then we went to visit her new baby brother. Arriving at the hospital, she ran up to her mother, grabbed her toque by the top, yanked it off and said, "Look, Mom, Granny done my hair."

These restaurants that have a double door leading to the wash room can be quite confusing to a little boy. Ryan looked around for a long time and finally came back to their table and said, "Dad, there's 
nothing in there but a waste basket, a light and another door."

Ariel was slouched in her chair looking like she had reached old age. "I'm already eleven" she kept repeating. Then looking at us grandparents she added, "The years don't matter to you, do they?"

Tedd had started school and was sounding out words just everywhere. When he was spending time in the men's room at Kenosee his Dad went to check. "Are you coming, Tedd?". He replied: "No, Dad, I'm not finished reading."

After Sunday service, Rochelle said, "Dad, I know God's in my heart." Then holding her hand on her heart, feeling the thump, thump, she added, "I can feel him now, he's doing his exercise."

Grant was terribly nervous of the elevator in the Plains Hospital when visiting their Dad on the top floor. As time went on, nature called, and his mother brought him to the bathroom. He stood outside the door, had a good look inside, looked at his mother and asked, "Does this thing go up and down?"

Natalie had been promised time and again that we would take her to the 'office where Daddy works.' The day finally came when we were able to bring her there. She went directly to the big office chair, patting the seat with her little hand she repeated over and over "This is where Daddy works, this is where Daddy works."

Michelle was getting a repeated lesson on manners. "What do you say when you want something?" her mother asked. "Please" she answered. "What when someone gives you something?" "Thank you." "When you sneeze, what do you say?" "Hatchoo" she answered.

Camille was very disappointed with Santa when she got up Christmas morning. There was an empty milk glass on the table, cookie crumbs all over, even on the floor. "You'd think he'd clean up after himself" she said.

Damien was visiting from the city. Coming down stairs one morning he sat there for the longest time watching me kneed bread dough. "You having fun in the play-dough, Grandma," he finally asked.

Brett was a very early talker. He got quite a chuckle out of his grandmother when she changed his diaper and he said "Thank you."

Mark however was not at all interested in talking. His brother was forever going through animal books making him repeat the animal words. When he got to "Hippopotamus," Mark said, "Too hard."

It was time to tell Jessica that mother was going to have a baby. "Let's go buy one right now," she said. "You don't buy a baby," Mother said. Before she could say any more, Jessica said, "Oh yes, you can. I saw them in the carts at the Super Store." 
Francine went out to play on the lawn, the first snow of the season. When she came in the patio doors, I helped her with her parka and boots. "Tell me where to put away your parka," I asked her. She brought me to the back entrance and pointed to the spot on the floor where I was to put away her parka.

We hadn't seen Melissa for well over a year. When she was told we were coming she asked, "Is that the Grandpa and Grandma that don't have holes in their ears," she asked. You see, we both wear hearing aids.

Kira's dad teaches bakery at the College. The first thing Kira greets him with at night is, "What did you bring home today, Dad?"

Max is beginning to say the odd word. His baby talk is worth a thousand words. If you're having a glass of wine he likes to bring his milk bottle up and call, "cheers."

Cameron has just passed his first birthday. He was really enjoying sloshing through the Vancouver water puddles. He has an exciting birth date, Boxing Day!

\section{Reunion: Round Lake, 4-7 August 2000}

Camp O'Neill on Round Lake was used for another Beaujot-Mullie reunion on the August 2000 long weekend. Besides various activities in the camp and on the lake, people gathered in ten cars for the annual mass at Saint Hubert and a visit to both cemeteries. The Kipling Citizen carried an account of the reunion and an article on the old Saint Hubert Cemetery (See Appendices 7.1 and 7.2 at the end of Chapter 7).

\section{Mullie/Laforge/Beaujot Reunion: Camp St. Jean Bosco, Zeden Lake, SK}

The Laforge family, and Monique Pulvermacher in particular, organized a 2002 reunion of the descendants of Paul and Julienne Mullie at St. John Bosco Camp on Zeden Lake. Monique was at the time on the Board of St. John Bosco Camp and many from the Laforge family had been at this summer camp located $165 \mathrm{~km}$ northwest of Zenon Park (or $145 \mathrm{~km}$ northeast of Prince Albert). A cook was hired, with various others volunteering as assistants and for clean-up. Besides much visiting, several activities were organized including archery, canoeing, ball games, singing around the campfire, and hiking. After breakfast on Sunday, we gathered for singing and prayers in the chapel. Pictures were taken of the four families: Laforge, Mullie North, Mullie South and Beaujot.

\section{$60^{\text {th }}$ Anniversary of Mike and Jeanne Mullie: Nipawin, SK, 8-9 August 2004}

The next reunion was on 8-9 August 2004, celebrating the $60^{\text {th }}$ Wedding Anniversary of Mike and Jeanne Mullie, then retired in Nipawin. Appendix 7.3 (see the end of Chapter 7) carries the memories and stories told, in as much as they could be published in The Nipawin Journal. Besides Mike and Jeanne 
Mullie, the older generation included Mike's sister Dorothy and Leon Beaujot of Kipling, and Jeanne's stepbrothers Felix Mullie of Edmonton and Roland and Mary Mullie of Arborfield.

\section{$60^{\text {th }}$ Anniversary of Leon and Dorothy Beaujot: Kipling, 14-15 July 2005}

Dorothy and Leon Beaujot were married on 14 July 1945. After nine children, 20 grandchildren and 4 great-grandchildren, family and friends celebrated their first 60 years of marriage on 14-15 July 2005. Among the 300 people who came, there was strong representation from Driscoll, Laforge and Mullie families. ${ }^{8}$

Festivities started with a tea on 14 July in Leon and Dorothy's yard, followed by dinner and program at Kipling Hall. Pictures taken over the years were on display, and guests were invited to put items on a "time line" that filled one wall of the hall. Their daughter-in-law, Judy Wooff provided flowers from her garden, enough to have flowers on each table, adding to the banners and balloons that decorated the hall. Their sons Fred and Pat organized a slide show that ran in the background. Various people spoke at the anniversary dinner. Appendix 7.4 carries the talks of their children, covering the evolving decades (an abridged version was printed in The Kipling Citizen on 26 August 2005, p. 13).

The evening started with a thoughtful moment as we remembered their granddaughter, Camille Fry, who had died in a boat accident just a month earlier, on 9 June 2005 in Kelowna, British Columbia. She had just completed her second year at the University of British Columbia -- Okanagan Campus. Her parents, Leona and Russell presented a recording of the testimonials given at her funeral. Camille had studied in French, including spending half of Grade 10 in France where she also visited the Largeau family. The family will always remember how creative she was in dance and rhythmic gymnastics, and her spirit of adventure and openness on the world.

On 15 July, after pancake breakfast in their previous farmyard, catered by Norbert and Sam Beaujot and family, Leon and Dorothy renewed their wedding vows at St. Hubert church. This was followed with a procession by car to the old and new St. Hubert cemeteries, to the original Mullie farm, to the site of Golden Plain School where Dorothy and the oldest Beaujot children had started their schooling, to the farm of Pat Beaujot and Judy Wooff for a coffee break, and finally to the farm of Doreen and Dean Gardner for a wiener roast.

\section{Dorothy Beaujot, 90 ${ }^{\text {th }}$ Anniversary, Kipling, 18-22 July 2007}

Dorothy wanted a smaller gathering for her $90^{\text {th }}$ birthday. The family gathered on 18-22 July 2007 to mark the occasion. Kipling neighbours, Bill and Gail Haanstra had generously offered their home for the

\footnotetext{
${ }^{8}$ People came from Kipling, Kennedy, Langbank, Whitewood, Rouleau, Radville, Regina, Saskatoon, Prince Albert, Bruno, Arborfield, Nipawin (Saskatchewan), Flin Flon, Crystal City, Winnipeg (Manitoba), Calgary, Edmonton (Alberta), Kamloops, Summerland, Princeton, Rossland, Abbotsford, 100 Mile House (British Columbia), London, Toronto (Ontario) and Topanga (California).
} 
"away" families to be nearby, including several who camped in the yard. Dorothy's brother Mike Mullie had also come from Nipawin.

On 19 July, the family organized a community tea in the backyard of their Kipling home. It was a lovely day, and Dorothy enjoyed the numerous flowers brought by her daughters and daughters-in-law Doreen Gardner, Jeanette Beaujot, Dolores (Sam) Beaujot and Judy Wooff. In the following days, there were picnic brunches, suppers and pancake breakfasts at the homes of Jeanette and Brian, Doreen and Dean, Pat and Judy and Norbert and Sam.

On Saturday night, the family gathered for supper and a birthday cake in Dorothy and Leon's backyard. The family presented their mother and grandmother with a scrap book of pictures, dried flowers and small messages, including pages for each descendant: 9 children, 20 grandchildren and 5 greatgrandchildren. The words for ten of her favourite songs were distributed, with singing led by Karen Beaujot and Kira Warje on keyboard.

Many pictures were taken, including one with Dorothy and Leon and their nine children, one of the nine couples, and one with the grandparents in the midst of most of their grandchildren and greatgrandchildren.

At age 90, Dorothy was oldest among the 10 surviving first cousins on the Mullie side (from oldest to youngest: Dorothy Beaujot, Michel Mullie, Marie-Louise Roland, Alfred Mullie, Marcel Mullie, Thérèse Lanthiez, Jean Mullie, Felix Mullie, Pierre Mullie and Henri Mullie) and also the oldest of the three surviving on the Smets side (Dorothy Beaujot, Lucien Dutois and Michel Mullie). Originally, there had been 30 first cousins on the Mullie side, born between 1907 and 1932, and 28 on the Smets side, born between 1890 and 1922 (see Appendixes 3.3 and 3.4 at the end of Chapter 3).

\section{Leon Beaujot, 90 ${ }^{\text {th }}$ Birthday, Kipling, 15-16 August 2009}

Two years later, it was Leon's $90^{\text {th }}$ that brought the extended family together. Besides the immediate family, the invitation list included their nephews and nieces from the Driscoll, Laforge and Mullie families, along with some of Leon's cousins from the Payot, Pirlot and Gatin families (descendants of the Canadian sisters and brother of Leon's father), and friends from Saint Hubert, Langbank and Kipling. Congratulatory notes were sent by Martine Parent of Bourseigne-Vieille, Belgium, Lucien Dutois of Alken, Belgium and Jean Mullie of Le Havre, France.

After the reception and dinner at the Kipling Hall on 15 August, activities continued the next day with a community open house tea, picnic and BBQ at the Langbank home of Jeanette Beaujot and Brian Dean. The picnic included outdoor games, various races and competitions, bringing back memories of the annual summer church picnics at St. Hubert. The three-legged race and the potato bag race were a hit among all the grandchildren. A thunder and lightning storm and a heavy downpour forced the closure of the games, but Jeanette and Brian's newly renovated garage allowed everyone to continue visiting indoors, animated with drinks, a BBQ and pot-luck supper. 
Besides Leon's speech (see Box 7.3 at the end of Chapter 7), the highlight of the reception was the first showing of a 40-minute film entitled Leon and Dorothy by The Fireside Film Company (2009). ${ }^{9}$ This filming company had been hired by Corbin Bernsen to create footage that might be used in a documentary on the movie Rust that Bernsen was producing. ${ }^{10}, 11$ As a volunteer, Pat Beaujot had found that Fireside's main activity was the production of documentaries of elderly people for their families. Pat arranged to have the company interview and film Leon and Dorothy Beaujot in their Kipling home. ${ }^{12}$ The film also includes pictures taken over the years, for instance, Leon with the Flinton School Softball Team $^{13}$ in the mid-1930s, Jack and Leon Driscoll on horses at their farm, Dorothy operating a suction grain auger, and the house being moved from the north farm to the south farm. In a particularly memorable sequence, Dorothy tells the story of how she calmed a team of six horses when one of them was out of control as she was working summerfallow on the Mullie farm. The film ends with pictures taken at Dorothy and Leon's $90^{\text {th }}$ birthdays with "Save the last dance for me" playing in the background. At the Kipling Hall reception, the film ended with a thunderous standing ovation.

The families gathered pictures which Fred Beaujot mounted into an electronic picture frame as a gift to mark their Dad's $90^{\text {th }}$ birthday. At the reception, Rod Beaujot distributed his 80-page draft manuscript, "90 Years of Memories."

On the Beaujot side, Leon was the youngest and only survivor in the generation of 20 first cousins, born between 1881 and 1919 (see Appendix 3.1 at the end of Chapter 3). On the Sénéchaud side, we have managed to document first cousins from three of the five siblings who lived to adult ages. Leon's mother, Bertheline Beaujot, her sister Radégonde Largeau and brother Ernest Sénéchaud had a total of 22 children, born between 1902 and 1933 (see Appendix 3.2). At Leon's age 90, the survivors in this first cousin generation were, from oldest to youngest: Alice Martin, Leon Beaujot, Gisèle Chambon, Fernand Sénéchaud, Louis Sénéchaud, Rémi Sénéchaud, Henriette Molton and Gilbert Sénéchaud.

${ }^{9}$ This film is available on Youtube by searching "youtube \& Leon Dorothy": https://www.youtube.com/watch?v=dsHPUze4Go

${ }^{10}$ The film Rust, written, directed and produced by Corbin Bernsen (trailer available on youtube) is the story of a priest suffering a crisis of faith who comes home (Kipling) to heal and there solves a mystery about the death of a family in a house fire (See "Saskatchewan town parlays paper clip fame into film deal", CBC News, January 27, 2009). The house used in the fire was on the abandoned farm site on NE quarter of 20-13-3 (see McIntyre, 2007 and McIntyre and Bonnell, 2009).

${ }^{11}$ The filming of Rust in Kipling is one of the outcomes of a 2006 media sensation where B.C. blogger Kyle MacDonald started with a single red paperclip, seeking to make successive trades on line to acquire a house ("Saskatchewan town parlays paper clip fame into film deal", CBC News, January 27, 2009). The trades included a pen, doorknob, an "afternoon with Alice Cooper", a snowglobe, ... and an acting role in a film that Corbin Bernsen would produce. The town of Kipling offered a house that had come under its possession in exchange for the acting role. When auditions were announced for the acting role, some 160 people came to the town hall for the occasion. ${ }^{12}$ Pat Beaujot scanned various pictures, getting his parents' help in identifying their proper locations in the film. As is obvious in Leon \& Dorothy, the interviewer and cameraman from The Fireside Film Company really enjoyed Leon and Dorothy and their stories.

${ }^{13}$ See picture in article by Darcie Thom on "Historical landmark lost in fire", The Kipling Citizen, 15 May 2009 (vol. 73, No. 31), p. 1. 


\section{Box 7.3 Leon Beaujot: On my children and their spouses}

At the banquet celebrating his $90^{\text {th }}$ year, Leon Beaujot:

Let me first thank Dorothy for looking after me so well all these years, if it was not for her, I would not be here. But, I mostly wanted to say something about each of my children, before they get to say too much about me.

When Roderic was small, Norbert was always following him. Once a rooster attacked Norbert and I ran over hearing much screaming, yelling and crying. I took my cap and knocked the rooster off Norbert. Then I asked Roderic why he had not done that to protect his brother. Roderic responded: "because I didn't have a cap."

When Liz, who was of Dutch origin, married Rod, we were getting some flack during our trip to Europe that none of our children seemed to be marrying people of Belgian or French origin. We said this was Canada and we were building a mini-United Nations.

Norbert found Sam to marry, a great lady. I know that he was never hen pecked but he was definitely rooster pecked.

Fred was small for his age and he seemed to lack something in his diet because he was always eating dirt. When we travelled, he would lick the dust off the car. This was good because that way we did not have to wash the car as often.

When Fred wrote to say that he was marrying Karen, he said that she was Finnish, but we could not understand his writing which seemed to say that she was "finished."

Honory had his first job in Grade 11 on the pipeline. We met one of the bosses who had just fired a guy because he did not want to work in the mud. He said that he would be happy to hire a hard-working farm boy, and that after a while he would no longer be in the mud. Sure enough, when we went to visit, Honory was mud from head to toe, but now when we visit him in the office from which he engineers the pipeline, he is in white shirt and tie.

When Honory told us that he had met Deanna, from Argentina, and that she was coming for a visit, he also said that she did not speak a word of English. We went to Kipling to learn a few words in Spanish, like "welcome to Canada." It was only after a few days that we were told that Deanna could speak English very well because she had been a school teacher in Argentina, teaching English.

When Leona was born, we were so happy to have a girl even though it disrupted the plan to go for a baseball team, as we already had four boys. Leona became a teacher of Math and French, and she met Russell Fry. He was a nice guy and all that, except that Leona's students started to call her Mrs. French Fry.

Doreen was always a hard worker and when she announced her marriage to Dean Gardner, we thought this would be great as we would get much help in growing big gardens. Then we found out that, in spite 
of his name, Dean mostly works in the fields. But we get lots of meals with Doreen and Dean, enjoying the produce of Doreen's garden.

Adelin was the youngest with us in our first big trip, to Expo 67 in Montreal. Rod got us to also go to Quebec City so that we could see the Plains of Abraham. When everyone was admiring the geographic location, Adelin kept looking up and finally asked, "how come I cannot see the airplanes? Adelin married Larz, a pastry chef who is always warmly greeted by their children when he comes home, as they are looking for goodies.

Pat was always close to his mother when the others were at school and he had not yet started. When the house was being moved, he was inside with his mother who was preparing lunch for the workers as the house was being inched onto its new foundations. Looking intently out the window, he suddenly declared: "I know what they are trying to do, they want to put the house over that hole." When he went to university, we asked the others with whom Pat was living how he was doing. They said he was doing fine, in fact he was the Chair of the Entertainment Committee. We asked what that meant, and they said that when we have a party he is the one who orders the booze. When he first married Judy, she was doing massage work on the side and we took some treatment for our bones and muscles. But we have chickened out now that she has turned to hammer and saw.

When Jeanette was small, Rod and Norbert were away at university and seldom home at the same time. Once when they were both home she suddenly said: I thought I had only one big brother but now I see that I have two. Jeanette thanks us often because she got to be home alone and to take more trips with us than the rest of the family. She is really making up for it now, helping us a great deal in our old age. Jeanette and Brian spend so much time at Kenosee, that I think they may move there some day.

We are sometimes teased about such a big family, and we still did not get a ball team, but there is not one of them that we would want to be without, we are proud of them all, and so happy to have them all with us today.

\section{Reflections ... on retirement}

When talking about his life, Leon would often say how lucky he had been compared to his parents. Félicien and Bertheline Beaujot suffered from serious health problems and financial losses. They had not been able to enjoy life in retirement. Félicien died at age 67, having suffered from migraine headaches that eventually brought debilitating dementia. Bertheline died at 70 , having received only one Old Age Security payment.

Leon continues: My parents had so little by the time they were older. Dorothy and I also started with very little, but we went through those years and we feel very lucky compared to our parents, as we can now enjoy the good life while they had it hard all their lives. I would not wish this on anyone, yet they call it the good old days. 
Dorothy joins: We moved to Kipling in 1989 when Leon was 70. It was a good time to move off the farm and start a new life in town. We have been very fortunate, especially as we compare ourselves to our parents, we live like millionaires here, and our children are all healthy and doing well.

Leon: Some people would say that moving off the farm would be the end of them. Everyone has to decide for themselves. It is not good to be stuck in a job, or stuck on the farm, just to keep the farm going.

\section{Reflections ... on community}

On thinking of his parents' early lives, Norbert Beaujot observes that it was a small world, limited by roads that were not passable in winter, even sometimes in summer. Getting off the farm was often not beyond going to church. Saint Hubert was a big place.

At the celebrations marking the $100^{\text {th }}$ anniversary of Langbank, Dorothy was asked to talk about the Golden Plain District. Her July 2005 speech is copied in Box 7.4.

\section{Box 7.4 Dorothy Beaujot: The olden days in Golden Plain}

Talk given at the occasion of $100^{\text {th }}$ anniversary of Langbank, July 2005

By Dorothy Beaujot

In the late 1890s, there wasn't a tree to be seen between here and Whitewood. Leon's Dad often told us that on a clear day he could see the town of Whitewood from his homestead near St. Hubert.

The Golden Rod, a plant that turned to gold in the fall, took over this area. When Archie Cowan arrived to the district he looked out into the horizon, all he could see was gold. It is a "Golden Plain," he said, and the name stayed.

I must begin by saying that most of my information is from an essay that Agnes Boutin wrote when she was in school in Golden Plain.

The district was formed and granted, dated July 5, 1886. The first school was completed on 22 December 1896. It was built a few yards west of the John Blackwood house and named Golden Plain No. 70 , which meant that it was the $70^{\text {th }}$ school built in the North West Territories. It had then 15 pupils.

In those years it was unusual for students to reach grade 8 . The country children were needed at home to help on the farm. It is not unusual to hear someone say, "my Granddad just got his grade 5". After that he would have been self-taught.

The Golden Plain School was closed 1887 to 1896. In 1914, the school barn burned down. At that time the pupils were mostly south of the school and it was decided to move the school one mile south to 
make it more central. This location was often called the four corners.

My first recollection of Golden Plain was 1925. I was then eight years old and had been in school at St. Hubert which was closer but not our district, which meant that our folks had to pay for our schooling. You all heard of the "Dirty Thirties." It was at that time that my sister, brothers and I were at Golden Plain.

I'll always remember the Sunday that we drove to Tom Blackwood's (father of Agnes Boutin) who was trustee at the time, to let him know that the four of us would be going to school at Golden Plain. He was so happy to hear this. They were to close the school because there were only three pupils for the coming year. These were the Wiltons, Mable, Pearl and Tom (my age) and across from them was Bun Tait.

Golden Plain: The typical country school, complete with barn and two outside toilets, His and Hers.

We got quite a chuckle seeing the notes that Agnes has of her Dad as school trustee. At one point they had to order toilet tissue for the year. However, they run out before the year end. They had forgotten the school picnics, the ball games played against neighbouring schools, the card parties, the bingo parties, the showers, the Christmas concert, the community plays put on in the winter. There was so much talent there, and when Dave Blackwood took the stage with those Scotch songs, we felt we were at the Globe Theatre. On Sunday, the minister would be out from Kennedy and the school would turn into a place of worship.

There is such a great book out called, "Syrup Pails and Gopher Tails: Memories of the One Room School." These are all stories of the early years, some very hilarious and some very sad. Syrup pails is what we all used for lunch pails, they were so hard to open. Our youngsters were lucky to have a friend like Jack Szilagyi to open their syrup pails at lunch time.

"Gopher Tails," in the early 30s the area was over-run by gophers. The district decided to solve the problem by paying 3 cents for every gopher you destroyed. First thing in the spring we would be shooting, trapping, and drowning out gophers. To prove that we had destroyed them, we were to bring the gopher tail to school. The teacher then was to count the tails and keep a careful note of which pupil brought them in. They would stay in her desk drawer till the end of the season and were then brought to the Municipal Office.

At this point in the speech, Dorothy realized that she had left the last page of the speech at home. She got quite a laugh and standing ovation when she finished by saying "I forgot the last page."

Continuing here from the recovered page:

This is to certify that we have received and destroyed 1725 gopher tails turned in by Miss Muriel Ringalt, 6 July 1932. 
I know 3 cents sounds ridiculous to you, but in the 30s, come picnic day, you could buy a small ice cream cone or a chocolate bar for 5 cents.

This wouldn't be complete without saying a few words about horses. For many, many years our main means of transportation.

Where we lived, which is where Edward and Sherry Mullie live now, we were 17 miles from Whitewood, our town, and four miles from school of which for two of those miles there was no road. We drove through fields and pastures and a valley where water ran down the creek most of the year. Come spring break, it was quite an ordeal to drive the horses through the creek which flowed with melting snow and ice. We drove through the two Blackwood farms, which meant five gates to open and close morning and night.

If you should be driving home through the fields on a dark and stormy night after playing cards or crokinole at the neighbours, you could trust your horses to find their way back home.

If you were driving through the country in those early years and you saw farm machinery pulled by six horses, or four horses on a binder, that could have been me driving them.

\section{Reflections ... on parenting}

When asked about parenting, Leon would often say that he came to it without much knowledge, partly because he was the youngest, not only in his immediate family, but also among his Canadian first cousins. Once his cousins Emile and Bernadette Gatin were visiting in the home of their Uncle Félicien and family, and they forgot to take the dirty diapers back with them. As Leon's mother was preparing to wash the diapers before returning them, he said: "Surely, you are not going to wash these dirty things." For the rest of her life, Bernadette would remind Leon of how naïve he had been on the tasks of parenting.

When she was asked about parenting, Dorothy said: It was quite natural. It was good to talk with neighbours who had children of the same age.

Reflecting on the parenting of his own parents, Leon said: My Dad was not well, and my mother would yell and complain a lot. When I was six and my sister and brother were at school, my Dad would take me out in the field to work the summerfallow or sow the crop with horses. He would sit on the side of the previous row and as we did the next strip we would change places so he was on the right side to follow the previous row. We would come back home covered in dirt dust. It was so enjoyable to be working with my Dad. 
Leon had seen his father-in-law parenting his adult sons on the farm: Grandpa Mullie had to be the boss. His eldest son Raymond got involved in making farm decisions, but it had to be the Dad's way. He was a perfectionist, especially when it came to weeds, and it drove his children crazy.

Dorothy continues: Grandma Mullie was pretty good at parenting. My Dad looked after the fruit trees, but not the garden, mother also did the chickens. He looked after the cattle, but never did the milking, nor did my mother. Mother had thought that one of the quarters should have been in her name. Mom would look after getting us to school, and she would help us with homework, never Dad. The nuns were not doing it right, we changed schools, in Golden Plain we learned new topics, and the teachers had techniques to teach reading. Dad would help us go to school.

Adelin Beaujot remembers her mother saying that she always enjoyed letting the kids play as she felt she had been deprived of play in her childhood years. When Dad was driving into the lane, Mom would say: OK kids, get back to work, Dad's home.

Adelin continues: In my teen years, when I wanted to do something that Dad disapproved of, he would say: "I wish you wouldn't ..."; leaving it up to me to ultimately decide. When I reflected on this in my later years, I realized that Dad was innately clever at parenting!

Adelin: I feel we were fortunate to have a good balance of softness and caring discipline with Mom and Dad's styles of parenting. An example of Mom's gentle, caring style: If one of us got hurt, physically or emotionally, Mom would secretly give the upset one a handful of raisins to privately enjoy in the sewing room. That solved the problem in no time!

In many ways, Leon and Dorothy were both very dedicated to their children's education: getting them to school in difficult circumstances, helping with homework, preparing nutritious lunches, making friends with families from the school, thinking of higher education and helping with associated expenses. While there was often not much spare money, when it came to education, they would find a way. Leon would say that investing in education is like investing in land, with a long-term pay-off.

\section{In hindsight: Benefits of the war experience}

Leon's conscription in May 1941 brought many hardships including three "lost years" and the delay of their marriage. With the benefit of hindsight, some positives can be noted. The army brought Leon from southwestern Saskatchewan to both ends of the country, spawning a continued interest in travel. He developed a knack for finding connections as he talked to strangers and made lifelong friends. With her brother Mike Mullie also in the army, Dorothy had far ranging responsibilities for farm work. She got to know how to look after machinery and to make decisions that would optimize farm production. Her experience in handling horses enhanced her patience in calming others, including baby and adult humans. As she later interacted with farm wives, she was often dismayed by how little they knew about farming; they were not even paying attention to what had been planted in which field and how the crop 
was maturing. Dorothy's farm experience enhanced the common interests of the couple, including making decisions together on both farm and family questions.

Other benefits resulted from government policy relating to veterans. The federal government's determination to maximize the economic integration of returning soldiers, and their return to family life, brought helpful policies like the Veterans' Land Act. ${ }^{14}$ Given what Leon would call his "next to nothing" military wages ${ }^{15}$, and the devastating hardships suffered by his parents, it would have been almost impossible for Leon and Dorothy to establish a viable farm, had it not been for VLA loans for machinery and land.

Other policies related to families. The introduction of Family Allowance in 1945, as Canada's first universal welfare program, supported families in having children (Guest, 2013). There were encouragements for women to focus on the family, making room for returning soldiers in the labour force. Some have called this period a "golden age of the family" with a breadwinner approach to the division of earning and caring (Beaujot, 2000: 243, 330-346). The orientation toward breadwinner families, along with the favourable post-war economic conditions, and couples making up for lost time during the depression and war years, were important factors underlying the baby boom in Canadian demographics. ${ }^{16}$ Given their good health, and seeing various benefits to large families, Dorothy and Leon did their part in generating the baby boom. This boom in childbearing occurred before the alienation from the teachings of the Catholic Church on contraception, and before the Gender Revolution that would promote gender equality in earning and caring, rather than a breadwinner model.

\section{From retirement to assisted living}

Already at the time of the reunion for Leon's $90^{\text {th }}$, there were discussions about the need for more assistance. In 2000-2006, Jeanette worked in Kipling, and several times per week she would spend her lunch break with her parents. Increasingly, she helped with gardening and the flower bed. When Jeanette was no longer going to Kipling for work, she continued to clean their home once per week. After their parents stopped going to Florida, Doreen and Jeanette had put up a wallpaper mural of a tropical scene in their bedroom. Dorothy and Leon loved this mural and showed it to everyone who came to visit. In October 2009, they called on Leona who spent two weeks, coordinating various improvements to ensure that all was in working order in their Kipling home: high efficiency furnace,

\footnotetext{
${ }^{14}$ Prime Minister W.L. Mackenzie King had witnessed the hardships experienced by soldiers returning from the Great War and he was determined to do better after the war that started in 1939 (Neary, 2011: 62-63).

${ }^{15}$ As of February 1943, a Private Soldier aged over $171 / 2$ years of age with 6 months service received $\$ 1.50$ per day (Department of National Defence, 1944). The per diem of $\$ 1.50$ is equivalent to $\$ 22.24$ in 2020 Dollars, or $\$ 8,120.00$ for one year of service.

${ }^{16}$ The baby boom can also be seen as a period between two transitions: the demographic transition that brought smaller families over the period 1870 to 1940, and the gender revolution that brought family change after the mid1960s: more flexibility in union entry and exit, and an acceptance of greater variety in family forms (Beaujot, 2000: 241-243). See Gauvreau et al. (2018) for an analysis of the importance of earlier and more universal marriages, and the survivorship of children, to the baby boom.
} 
dishwasher, clothes washer and drier, and low flush toilet. Leona's three-page report helped others to understand how our parents were coping with living on their own.

There were discussions about having live-in help, but Dorothy was very much against this. Leon had always looked after grocery shopping, and by now he was also doing most of the cooking, becoming an expert in putting most of the meal in the steamer. Dorothy liked to participate, but her failing shortterm memory meant that she needed supervision. She would forget that she had already put salt in the soup, to the point that the salt had to be hidden.

Given the difficulties of living on their own, Leon and Dorothy explored the possible private care homes. Regina was the obvious choice, with Norbert and Sam, along with their three children residing and working in Regina, and Doreen, Jeanette and Pat often in the city. Norbert helped his parents to explore alternatives and to determine what was most suitable within budget. They settled on Victoria Park Personal Care Community, 2400 Arens Rd, on the east side of the city, with good access from Kipling, Langbank, Kennedy and Whitewood. Having so often driven in Regina, Leon was well situated to drive from the Personal Care Community to other locations in the city for appointments, or even to drive back to the area of their previous residence, where their Saskatchewan children were living $(150 \mathrm{~km})$.

Norbert organized the move, and they called on Leona once again to help with packing and deciding what they could take with them to Regina. Surplus items were boxed for storage in the garage, so that the house could be ready for sale. After a long day of packing and sorting with everything spread out all over the house, boxes everywhere, they decided to go out for supper and leave the work behind. On returning home, Dorothy took one step into the house, saw the chaos all around and exclaimed, "What has happened here?" Her short-term memory had deteriorated considerably, but she could remember things from earlier times, often saying "that was not yesterday".

Along with others, Norbert and Sam ensured that favourite pictures were set up in their new residence, to make it look like their home. This was all done by the beginning of June 2010 . Various members of their immediate and extended family, along with friends, soon came to visit. All found that a good choice had been made.

Nonetheless, there are various disadvantages to living in a private care home, some of which only become apparent over time. While the common areas are nice, the living quarters are small, and it is not like being at home. One is interacting with strangers for meals and as soon as one steps out of the living quarters. Leon and Dorothy had always felt comfortable in getting to know other people, but this was different in a care home. Many of the residents are suffering from physical and mental health problems, posing difficulties in communicating. While meals are prepared, and the facilities are great, it still feels like living in an institution. There is a lack of privacy, with staff coming in unannounced. If one of their children was visiting and sleeping on the couch, Leon would tell them: "when you are changing, put your foot against the door so that no one can come in." 
While the staff was appreciated, and Leon made some new acquaintances, including a neighbour with whom he exchanged newspapers, he increasingly called on family members when there was a problem or assistance was needed. They also lacked the company of people they had known over the years, no longer meeting them in daily life, or dropping in. While Leon was good on the phone, there were few calls or visits from family and friends beyond the immediate family. We sought to ensure that family and friends knew where they were. For their $65^{\text {th }}$ anniversary in July 2010, we put a notice in the newspapers and sent the message to family and friends. Some sent messages or called, even from Europe, but with their advancing age there were fewer people of their own age and they increasingly interacted with their immediate family.

After his visit of 26 September to 3 October, 2010, Fred reported that his Dad was under much stress, having to deal with Mom's physical and mental health, while also feeling that his own memory was diminishing. Leon was worrying about what will happen if he is not there, and he wished that Dorothy would accept more help from the staff. As time went on, Leon concluded that they would be better off in Kipling. That way, if Dorothy was left alone she would be closer to her daughters.

They came to focus on seniors' apartments at the Kipling Manor (304 $-7^{\text {th }}$ Ave). Their doctor in Kipling assured them that he would help if they needed more assistance. They could take advantage of "meals on wheels" and Dorothy could go to the Willowdale care home for baths, as she had occasionally done when they lived in Kipling. As they discussed this with their parents, and exchanged many e-mails, the children came to conclude that they had to support their parents in their wish to move back to Kipling. At the same time, there were serious concerns, especially for their safety in living on their own and Leon having to do more driving while his dementia was affecting his sense of direction. We were also concerned that they would be separated if Mom had to be in a care home, with even the possibility that this would be in a town other than Kipling.

\section{Back to Kipling}

Honory and Pat organized their move to Kipling, with others helping to set their parents up for living in a seniors' apartment. Soon after their move to the Kipling Manor, Dorothy was hospitalized because of her persistent headaches. When this happened a second time, the doctor could no longer justify having Dorothy in hospital when she needed long-term care. In mid-May 2011, a space became available at the Willowdale care home in Kipling. We convinced Leon that Dorothy needed to be at the care home because he could no longer care for her on his own. He was never at ease with this situation because it meant that they had to be separated. He developed a strong dislike for Willowdale. The staff were concerned that if Dorothy was not at the home full-time, she would not want to come back. They were also concerned that it was unsafe for Leon and Dorothy to be going for long drives in the country. For instance, when Pat dropped in for a visit on 2 July 2011, they had been driving "all over the countryside on this beautiful day."

Given Leon's reluctance, the Manager at Willowdale worked out a "trial pass" to ensure that everyone understood how Dorothy was to be at Willowdale most of the time over the period 6-25 July, followed 
by a period ( 25 July to 8 August) during which she could be away without losing her place at the care home. During Adelin's visit, in mid-July, Dorothy had to be at Willowdale each night. The "trial pass" included allowing Dorothy to move back to the seniors' apartment with Leon on 25 July. Then a "case conference" was envisaged for 8 August to determine how to proceed from that point.

As Dorothy moved back to the Manor, there were times that she had to be at the care home, and the family became convinced that she would need to be at the home on a continuous basis. In the first week of August, Dorothy was hospitalized once again. The "case conference" on 8 August turned out to be a "cat and mouse chase". Doreen, Jeanette and Pat had come to Kipling for the meeting which was to include their parents and the manager of the Willowdale care home. We all thought it would be difficult to convince Leon to bring Dorothy back to the care home on a permanent basis. Instead, Leon brought Dorothy directly from the hospital to the care home and no meeting took place. During the visits of Leona in late August and Roderic in early September, their mother had to be at Willowdale at night. She enjoyed the outings, but there was often difficulty in having her come back to the care home as she did not know why she needed to be there by herself.

It was during the nine months in Kipling, plus the two months leading up to their departure from Regina, that the e-mail exchanges among their children reached the highest intensity. We would report on our telephone calls and visits, seeking to be on the same page in working out a strategy for accommodating our parents' wishes in the context of their health and associated limitations. We wondered how small families could cope with the needs of aging parents.

Doreen adds that she will always remember the words of the Willowdale case worker at the time of the attempted case conference on 8 August 2011. The case worker commented on how well we got along. She found it most heartwarming to see that we all wanted the same thing: for Mom and Dad to be happy and safe, with the 9 of us coming to an agreement without conflict. As she remembers this occasion, Doreen feels that it brought us all closer as a family.

\section{From Kipling to Weyburn}

After the return to Kipling, Leon was remembering that a cousin had been at the Hill Top Manor in Weyburn, a smaller private care home than the one in Regina. In the early summer of 2011, he talked with Fred and Jeanette about this possibility for a private care home. Shortly thereafter, Jeanette took her father for a tour of Hill Top and they were both impressed with the facility and the staff. Knowing also that Leon's niece Bernice Driscoll lived in Weyburn, they put themselves on the waiting list. When Roderic was visiting, he took his Dad for a second visit on 9 September 2011. Part of the attractiveness of Hill Top was that it was a smaller place, all on ground level, with 28 units divided into three pods. The price was also reasonable, and it did not increase as patients needed more care $(\$ 4,200$ per month for a double room in 2011). The philosophy of management was that, if the client and their family wanted, they could live out the rest of their lives at Hill Top Manor. 
In mid-December 2011, Jeanette and Doreen moved their parents to Hill Top Manor in Weyburn (160 $\mathrm{km}$ south west of Langbank or $115 \mathrm{~km}$ south of Regina). A note was sent out to family and friends where we reported that Leon and Dorothy were especially pleased to be together again. Dorothy was still frail with very limited short-term memory and frequent headaches. Leon was doing well, including some driving both in town and in the countryside. They enjoyed going for walks around the Manor, with Dorothy using a walker and Leon pushing her in the walker when she was tired.

Over the next two years there were ups and downs, but with several visits and phone calls, things went well. Leon's niece, Bernice Driscoll, was ever helpful, in small things and bigger ones.

On 24 March 2012, Dorothy broke her arm with a fall in the bedroom, necessitating an ambulance visit to the Regina General Hospital. Jeanette was already in Regina that day and met her Mom at the hospital, staying with her before and after surgery. As she prevented her Mom from thrashing her arm around, Jeanette was surprised by the strength of her now frail mother. In a state of delirium from the sedation, Dorothy said: "I feel terrible, I'm never going to drink again!" Jeanette observes: "Mom sure did well, going through surgery at that age, and it healed quite quickly".

At a doctor's visit in January 2013, where Jeanette was present, the doctor convinced Leon that he had done enough driving and that he should give it up. We immediately took the car away. We had been concerned about Dad's driving as he became more disoriented and had to look after Dorothy at the same time. Giving up the car was nonetheless hard because they much enjoyed taking car rides together in the countryside. In the previous summer, Leon related that he had been "pulled over by the police who asked if I had been drinking and said that I was going pretty slow. The police said he couldn't charge me. After all, when you want to see something, you slow down. Besides, it is too rough to be driving on the shoulder."

In May 2013, Jeanette came to Weyburn, picking her Dad up for a drive to the Farm Progress show in Regina, then doing the return trip back to Langbank. With our concern about driving, Jeanette had previously made similar excursions which were much appreciated. In September 2011, she had come to Kipling to take her parents on an all-day tour of Saint Hubert and the surrounding area.

In his visit of 27 May to 3 June 2013, Roderic took his parents for drives, including a trip back to Kennedy for lunch with Doreen \& Dean and Norbert \& Sam. Mom was initially not interested in going for a drive, but the staff at Hill Top insisted that it would be good for her to get out, and her mood would eventually turn around. On the way to Kennedy she said a couple of times, "this is a long drive". When having lovely sandwiches at Doreen's, she said, "whoever prepared this should be shot". Not like our Mom! After lunch, Norbert and Roderic took their Dad to Saint Hubert. On our return, Doreen and Mom were enjoying themselves on the hammock. We were afraid that she would not want to leave, but when we asked her to come back to the car she said "this is too easy" as she got into the wheelchair. On the way back she said, "when you look for it, you always find a good road". This would be their last trip together to Kennedy and Saint Hubert. 
When Fred and Leona were in Weyburn for a visit in September 2013, Dad was going over with them some specific requests that he had for their (his and Mom's) funeral service. It should take place in Saint Hubert in the summertime. He had not even considered the possibility that it would not be a joint funeral service. This was his final commitment to Mom that they would not be separated.

When they were in Regina, Norbert and Sam had overseen their finances, with Fred taking this over as of their stay in Kipling. Fred was able to follow their accounts and investments from afar. Once in about 2012 , Fred noted an ATM withdrawal of $\$ 600.00$. He called his Dad, asking him to check how much money was in his wallet. Leon was very surprised that there was $\$ 600.00$ and even more surprised to hear that Fred knew what was in his Dad's wallet.

The children continued to summarize their interactions with ongoing e-mail exchanges. We mostly felt that our parents were in a good situation. They liked Hill Top but missed the daily interactions with family and neighbours. There were limited conversations with other persons living at Hill Top, partly because many suffered from dementia. Our parents continued to call on their children for things that the staff could handle. On some occasions Leon would get very irritated, especially if someone would say something negative about Dorothy's condition. In early December 2013, Roderic reported, from his conversation with his father, that the staff was looking after feeding Mom, but he got angry when they were giving her too much too fast. He would come back to the observation that it was a nice place, but he wanted to be closer to the family. He also observed that It was very cold, and he was content to stay put until the spring.

\section{On being among the last surviving of their generation}

By the time of their deaths in March and May 2014, Leon and Dorothy had survived all their brothers and sisters. On Leon's side, his sister Flora (1911-1994) had farmed in the Handsworth ${ }^{17}$ area with her husband Joe Driscoll, then moved to Kipling in 1965 and to Calgary when her husband died in 1972 (Flora [Beaujot] Driscoll, 1992, Memories). Both in Kipling and Calgary, where three of her children lived, she worked as a nursing aide then in the prescription department of a drug store until retiring in 1976, at the age of 65. She even learned to drive on multiple-lane roads (Crowchild Trail), though her son Jack reports that his hair turned a whiter shade of gray as he was reminding his mother that she needed to signal before changing lanes, not afterwards. Flora and Joe had six children born between 1933 and 1950 and 20 grandchildren born between 1958 and 1976.

Leon's brother Albert Beaujot (1912-1988) worked as a carpenter first out of his home in Saint Hubert then in Calgary after moving there with his wife Grace Pelletier in 1964. Albert worked for Unrah Construction, retiring in 1977 at the age of 65. Albert and Grace had two children born in 1959 and 1963

\footnotetext{
${ }^{17}$ The Driscoll farm consisted of 7 quarter sections (North $1 / 2$ of 34-10-6, North $1 / 2$ of 33-10-6 and North $1 / 2$ and SW $1 / 4$ of 28-10-6 West of $\left.2^{\text {nd }}\right)$. Their son Leon Driscoll bought the farm in 1965, allowing his parents to move to Kipling. After farming for two years, Leon sold to the Lawrence Gentes family who farmed for some ten to twelve years. This land is now part of the reconstituted land base of the Pheasant Rump Nakota First Nation.
} 
and three grandchildren born between 1992 and 1996. Grace Pelletier had two previous children born in 1946 and 1948, with three grandchildren born between 1965 and 1971.

Dorothy's oldest sister Marie Louise (1911-1992) farmed at Zenon Park with her husband Philippe Laforge, retiring in Zenon Park in 1978. Marie Louise and Philippe had eight children born between 1946 and 1958 and 14 grandchildren born between 1975 and 1997. Dorothy's brother Raymond Mullie (1915-1999) and his wife Maria inherited his parents' farm at Saint Hubert, retiring first on the farm then to the Whitewood Care Home in 1997. Raymond and Maria had seven children born between 1947 and 1957 and 13 grandchildren born between 1967 and 1998. Dorothy's younger brother Michel Mullie (1920-2014) farmed with his wife Jeanne at Arborfield, moving to Nipawin at their retirement in 1985. Mike and Jeanne had four children born between 1945 and 1953 and 6 grandchildren, born between 1972 and 1991.

Dorothy (1917-2014) and Leon (1919-2014) farmed at Saint Hubert then Langbank, retiring first on the farm then to Kipling in 1989. They had nine children born between 1946 and 1965, and 20 grandchildren born between 1973 and 1998. By 2020, 13 of their grandchildren were married or in cohabiting unions, with a total of 18 children (great-grandchildren of Dorothy and Leon).

Besides surviving all their siblings, they survived all but three first cousins on the Sénéchaud side: Gisèle Chambon (1920-2017), Fernand Sénéchaud (1923-2019) and Henriette Molton (born in 1929); and four first cousins on the Mullie side: Alfred Mullie (1924-2016), Felix Mullie (1927-2020), Jean Mullie (born in 1929), Thérèse Lanthiez (1926-2016). Leon was the last survivors among the first cousins on the Beaujot side, and Dorothy was last survivor in the generation of first cousins on the Smets side.

When Leon Beaujot (born 1919) and Michel Mullie (born 1920) were celebrating their $80^{\text {th }}$ birthdays, I noted that they were of the generation of Pope John Paul II (1920-2005), Pierre Trudeau (1919-2000) and Nelson Mandela (1918-2013). It seemed at the time that Leon and Mike looked younger than this comparison group, having profited from the clean air of Saskatchewan. When I reminded Dad of this comparison during a conversation in December 2013, first he said: "Really, I'm over 80!" Then he said he "wouldn't go for a victory lap, at least not on a cold day like today".

\section{Together in death}

After a long life together, Leon and Dorothy died within three months of each other, on 6 March and 28 May 2014, just short of their $69^{\text {th }}$ Wedding Anniversary. They both died while residing at Hill Top Manor in Weyburn and their ashes were interred together at the Saint Hubert Cemetery. Dorothy Thérèse Beaujot (the marriage certificate says Dorothée Adeline Marie Thérèse Mullie) basically died of old age as her body stopped. Leon Beaujot (the marriage certificate says Léon René Paul Beaujot) basically died of a broken heart at the Regina General Hospital, after a second heart attack.

On 4 March 2014, Doreen got a call from Hill Top that Mom's heartbeat was very weak. With further news on 5 March, Jeanette and Doreen planned to drive in the next day, as did Norbert and Sam. Since 
the death appeared imminent, Pat drove through a snow storm to Weyburn, arriving at 8:30 pm on 5 March. He was able to report that the priest came to administer the Last Rites and that Mom took her last breath at 1:42 am the next day (see Appendix 7.5 for the e-mail exchanges in the family on 4 to 6 March 2014.

In the morning of 6 March, Norbert and Sam arrived in Weyburn, and later Jeanette and Doreen, staying the night, the next day Rod drove Dad to Regina, staying at Norbert and Sam's while Honory, Leona, Adelin and Fred arrived. On 9 March we drove to Kipling in two cars. As Rod and Leona were driving their father from Regina to Kipling, we realized the extent to which he had lost his sense of direction. He could not recognize where we were driving, even though he had driven over this road so many times. But he was not anxious about not remembering. He seemed to be appreciating how his mind was playing tricks on him. As we got closer to Kipling, he kept looking to the southeast and he eventually identified the Moose Mountains in the distance. Then he got his sense of direction back, but from the south rather than the west. He was remembering the route to Kipling as he knew it 80 years earlier when living at Handsworth.

The "boys" stayed with their father at Pat and Charlotte's in Kipling, with the "girls" at Doreen and Dean's. We had to be careful that Dad would not attempt to climb stairs during the night. As we awaited the return of Norbert's family from Mexico, we gathered at Pat and Charlotte's in Kipling, at Norbert and Sam's home on the farm, at Jeanette and Brian's in Langbank, and at Doreen and Dean's farm in Kennedy. On the evening of 14 March, we gathered for prayers at the church in Kennedy. By then many others had arrived: Karen, Larz, Liz, Ariel, Damien, Brett, Mark, Tedd, Grant and Max. Others arrived the next day: Norbert and Sam, Cory and Joey, Ryan, Rochelle \& Owen with Gabrielle, JoAnne with Brittany, Mason and Julia. The Funeral Mass, on 15 March, was held at St. Ann's Roman Catholic Church in Kennedy with Reverend Hector Seville as Celebrant. Leona and Honory gave the eulogy. Family and friends then gathered for a reception at the Kennedy Friendship Centre.

On 16 March, Honory and Leona drove their Dad back to Weyburn. We were not sure how he would feel returning to Hill Top Manor, by himself after such an intimate time with the family. The first thing he said as he walked into his room was how much he liked this room, that it was bright and sunny. He felt at home. He later expressed that he would feel very lost and lonely without Mom, but he would take it a day at a time. It was going to be a big adjustment.

The family remained in close contact with visits and phone calls. Leon enjoyed knowing what everyone was doing. He reported that he was delighted that he was getting "the royal treatment of a bath once per week ... they have a lift and the person getting a bath is lowed slowly into the water". He said that when he hears a noise, he would look to see and remember how he was paying such close attention to Mom when she was sick: "I was with her steady, it was good for me and for her ... we enjoyed being together, but that is the way it goes ... she is not suffering now. ... I miss the family ... and the car. At least Mom is not asking when we can go for a drive." 
At Easter, Doreen arranged for Dad to be picked up for church in Weyburn. He was touched by the ceremony, with so many people and lots of kids. He reported on how much he enjoyed having Norbert and Sam take him out for a meal before Easter. On another day, Father Ed Hengen came for a visit, picking Dad up so that Father would have some company as he went through the car wash. As he saw the picture that Jeanette took on an early spring car ride, Leon said: "here we are at Nickel Lake ... it's too cold for swimming, but very good for looking."

A few days later (2 May 2014), Pat and Charlotte came for a visit and they were delighted that Dad recognized them right away. They felt he had improved a lot since they had last seen him at Mom's funeral. On the previous Friday, he had enjoyed socializing at the afternoon dice game and wine event. He had not been able to enjoy himself in this way when Dorothy was not well. He was also in much better physical shape, grabbing his coat and walker to go for a walk, finding his own directions and picking up the walker to get over curbs.

On 27 May, Doreen was contacted by the nurse at Hill Top with the sad news that Leon had suffered a heart attack. Doreen went to Jeanette's to discuss what to do because he had signed an order for "do not resuscitate." Given that he was in pain they authorized medication for the pain and to have him sent by ambulance first to the Weyburn Hospital then later that day to the Regina General Hospital. Jeanette and Doreen then drove in to Regina where Norbert and Sam were already at the hospital, as well as their sons Cory and Ryan. Dad's condition did not seem that bad, and the physicians were even considering a pacemaker. Jeanette and Doreen drove back to Langbank that evening, with Jeanette coming to Regina the next day with the intention to stay with her Dad until he was released from hospital. In the evening of the next day, Leon suffered a second heart attack. Jeanette and later Norbert were by his bedside as he died peacefully at 7:02 pm on 28 May 2014. Jeanette wrote an account of "Dad's last day" which she sent to her siblings and her son Brett read at the reception (see Box 7.5).

\section{Box 7.5 Dad's Last Day by Jeanette Beaujot}

When I got to his room at noon he was sitting in a chair by the window. He spotted me just as I got to the door and he said to the aid in the room "There she is, there's Jeanette."

He had just finished lunch. He was looking good, no longer needing the oxygen tubes in his nose but was a bit confused why he had all these cords strapped to him. He said, "I think we should just unplug them all, I don't want them hanging off me this way all day". I told him we had to leave them plugged in because that way the nurse can check how his heart was and if we unplug them it will make an alarm go off.

He told me he had a good morning with Norbert watching a Blue Jays game on TV and said he had been out walking outside this morning and it was a very nice day. It's good that he thought he had been out for fresh air, but I asked Norbert later and they really did watch the Blue Jays on TV. He said Norbert will be coming back soon and thought Liz was coming too.

Dad was a bit confused, he knew he was in the hospital, but he thought he had bought the room and it needed to be fixed up a bit. He was concerned with making sure people knew what they were supposed 
to be doing with the room.

After a while he was feeling a bit tired and wanted to lay down to rest. Charles, the nurse, said it would be a good idea to rest since he had been sitting in the chair for two hours. After getting me to check to see if the lighting in the room was working ok he fell asleep.

The nurse came in and said there was a room ready for Dad in the CSU ward but wouldn't move him until after he woke up. Dad slept for about an hour until someone came in to take blood samples.

Since he was awake the nurse came in to move Dad into a different room. The aid was helping as well, telling Dad to roll on his side, then push with his arm against the bed and place his feet on the floor. Dad said, "I don't understand". I leaned over and said in his ear "Dad, they want you to get up and sit in the wheelchair." Dad said "oh, well, ok that's easy, why don't they just tell me what they want me to do?" He sat himself up, stood up, turned around to the wheelchair and sat down.

When we got over to his new room and met his new nurse Jill he asked her "is this the maternity ward?" She told him "no there are no babies here, this is the heart ward, we will be taking care of you and your heart here." All the staff really liked Dad, they thought he was "so cute".

Dad was having some abdomen pain throughout the day, they were trying to get him to pee, but he just couldn't do it into a container, he said he was "pee shy". The nurse decided to let him be and lay down for a rest. He was feeling cold, so she brought him a nice blanket that had been warmed. Dad thought that was just so nice. Feeling good, he fell to sleep for about another hour.

When Dad woke up the nurse came in to see if he would try peeing again. She wanted him to be comfortable and was quite concerned with his sore abdomen. She told him if he wasn't able to go she would have to put a catheter in to pee for him. Dad really didn't want that so said he would try again later. The nurse said she would come back after Dad ate supper.

Dad was sure that he had just eaten lunch and it couldn't be supper time already. I told him he had been sleeping off and on so that's what made the afternoon seem to go by fast. They brought his supper in, but he wasn't feeling too hungry. It was chicken, mashed potatoes and broccoli. One of his favourite meals, but not as good as Mom used to make. He decided to have a bit of it then pushed the tray away saying that's good enough.

I sat beside him on the bed. He was talking about the room again. He said, "it's a good room but we'll have to get some help to fix it up." Then his shoulders dropped, and he relaxed saying "I wish Mom was here, she would know what to do." I said, "you're right, Mom always knew what to do."

Dad was a bit cold and wanted to lay down and cover up. I helped him lay down and covered him with blankets. He said, "I'll move over, so you can lay beside me." I said, "it's ok Dad, you lay in the bed and I'll sit in the chair beside you." Dad said, "I guess there's not enough room for both of us."

When I turned away towards the chair I heard the alarm go off in the hall not realizing it was for Dad. I looked back at Dad and he was having another heart attack. The nurses came rushing in. They sat me down beside him, I held Dad's hand, and placed my other hand on the top of his head. The nurse gave him oxygen and morphine for comfort and instructed me to just be with him, hold his hand, talk to him, let him know I'm there with him. The heart attack seemed to last at least a few minutes. I told him he 
had accomplished so much in his lifetime, helped many people, had a big beautiful loving family, he was loved by many people, there was nothing more to do but to relax and go see Mom. I remember saying "I love you Dad" many, many, many times.

When the heart attack subsided Dad's eyes were still open, but he was not responding. His breathing was very slow, and his heart would stop for a while at times. I asked the nurse how long Dad might hold on and she said it's hard to say, it could be anytime or maybe even 6 hours. I called Norbert at 5:10 pm to tell him Dad did not have long to live. Norbert arrived, he sat on the other side of Dad holding his left hand. I called Doreen, she said she would get Dean to drive her in right away. We asked the nurse to call the priest to come in. The priest came at about 6:30, a half hour before Dad took his last long slow breath and his heart stopped at 7:02pm.

"We love you Dad"

Jeanette

Since it was now the end of May, we could trust that the roads to Saint Hubert would be passable. The funeral was held on 4 June at the Saint Hubert church, followed by the interment of Leon and Dorothy's cremated remains at the Saint Hubert Cemetery, and a reception at the Langbank Community Centre.

The mass was concelebrated by Reverends Rene Mangahas and Hector Seville who made a point of bringing some Pilipino culture into the service. Our hearts were uplifted by the way the priests celebrated not only our parents but the pioneers who founded the Saint Hubert community. Adelin and Roderic did the eulogy.

Father Rene would later write: "The eulogy inspired me to pick up on the theme of celebrating one's life, as your parents were an outstanding testament; ... the whole community gathered, with you - the siblings - leading, radiated and contaminated everyone with the spirit of joy and vivaciousness ... indeed all of us there got the joy 'virus'!"

As we processed to the cemetery on this lovely June afternoon, we remembered the many shared religious celebrations and social occasions that had sustained the community of Saint Hubert. 


\section{Appendix 7.1}

\section{Beaujot-Mullie Reunion at Camp O'Neill, 4-7 August 2000}

An informal reunion gathered 126 people at Camp O'Neill over the August 2000 long weekend. Ranging in age from five months to 83 years, people had come from Saskatchewan, Alberta, British Columbia, Manitoba, Ontario and England. There were 20 tents, three campers, others sleeping in the cabins, and still others staying up all night to keep various fires burning.

On the Beaujot side, the invitation went out to descendants of François and Justine Beaujot who had come to St. Hubert in 1892, where their children married into families with the names Gatin and Pirlot. The family names in the third generation, where Leon Beaujot of Kipling is the only survivor, are Beaujot, Gatin, Pirlot, Payot, Hancock and Driscoll.

On the Mullie side the reunion included descendants of two brothers who had arrived from Belgium in 1911 and 1913. Paul and Julienne Mullie farmed at St. Hubert, and Julien and Marie Louise Mullie in Arborfield. Together, they had eleven children, and those present at the reunion were Dorothy Beaujot, Mike Mullie, Jeanne Mullie, Alfred Mullie and Roland Mullie.

Most complete at the reunion were the descendants of Paul and Julienne Mullie. Their four children who lived to adult ages married over a short period at the end of the war: Mike and Jeanne Mullie, Marie Louise and Philippe Laforge, Dorothy and Leon Beaujot, and Raymond and Maria Mullie. These four couples had a total of 28 children of which 23 were at the reunion. These first cousins (third generation) have a total of 53 children ( $4^{\text {th }}$ generation or great-grandchildren of Paul and Julienne) of which 40 were present. There are three in the $5^{\text {th }}$ generation, all present though two of them will have been too young to remember. There were also three spouses present from the second generation, 20 from the third and five from the fourth generation.

Besides much visiting, the persons gathered enjoyed camping, eating, beer, boating, swimming, trampoline, playing ball, fireworks, taking pictures, campfires, singing, and more eating, drinking and visiting. Some were excellent pancake cooks, others at collecting money to ensure that we could pay for the fried chicken dinner. Enterprising youth found that they could melt beer and wine bottles together through the night. Many grey-haired surprised themselves at how well they could play baseball, although other surprises were in the distance to first base. It must be noted that some younger players were very agile and self-effacing in covering for their elders.

The weekend was not without its tense moments. A two-year old found that a penny in a seat belt could force mother to abandon the front seat of the van all the way from Vancouver. A running catch at baseball even produced blood but the nurse on site did not declare a handicap. A dive in the shallow end of the pool produced what first looked like a broken nose, but the cartilage came back to normal on the rough ride to Esterhazy before the doctor could inspect, and the deformity was not visible in the group pictures taken later that night. A canoe ride that started with a drop-off up stream had not allowed for the extra distance of the meandering Qu'Appelle River. As the night hours progressed, a 
zodiac went looking, even returning for more gas, but could not locate the canoe that did arrive back in time to profit from the warmth of the campfire.

On Sunday, ten vehicles went to the annual mass at St. Hubert, then visited both the cemetery by the church and the one on the bank of the Pipestone near the site of the old church. A brass plaque was recently erected at this location where ten persons had been interred in the period 1892 to 1903.

François Beaujot was the first person buried at this old cemetery.

Clearly, people vary in their association with such gatherings. The presence of distant cousins can cut into the time to visit one's own sister or brother. Some were heard to say, "I suppose I should know you," of the spouse of a first cousin. Others seem to know everyone, sometimes in more detail than one would want to have known. It must be admitted that such large reunions can cause a certain amount of tension. It is rumoured that there was a brief revival of the in-law support group that had been inaugurated at a British Columbia wedding.

All families like to think of themselves as unique, contributing to the sense of identity and belonging. In the case of the Beaujot and Mullie families, the gathering at Round Lake in August 2000 will remain etched in this collective memory.

Source: Revised from The Kipling Citizen 26 August 2000, p. 7. 


\section{Appendix 7.2}

\section{Old St. Hubert Cemetery}

A bronze plaque was erected on 3 August 2000 bearing the names of ten people who were interred at the old St. Hubert cemetery, before the church was moved to its new location across the Pipestone. The old stone church was demolished in 1903 and some of the materials were used in the building of a new church which was destroyed by fire in 1935 . The third church still stands at the centre of the St. Hubert community, southwest of Whitewood.

The names of the persons as listed on the plaque are: François Beaujot 1822-1892, Octavie Cottin 1893, Mrs Mathieu Dermody 1896, Cecille (Mrs Conrad Flick) 1894, infant twin Cottin 1897, Jules Collard 1901, Augustine Cottin 1902, Josephine (Mrs Jules Moiny) 1903, Louise Moiny, Jules Robin.

Some of the specific graves are still marked with steel crosses. Relatives from the various families of the deceased gave donations so that the plaque could be erected at the edge of the old cemetery.

François Beaujot was the first person interred in the cemetery, having died the same year as his arrival from Belgium in 1892. His wife Justine was buried in the new cemetery in 1904. Their seven children, of which four lived in Canada, are recorded in Descendants of/de François \& Justine Beaujot 1860-1979 published in 1979. The Canadians and their spouses in this second generation are: Eugène and Modeste Beaujot, Céline and Joseph Pirlot, Joséphine and Adolphe Gatin, and Félicien and Bertheline Beaujot. In Belgium, the second generation and their spouses are: Jules and Emilie Poncelet, Céline and Honoré Gillard, Agnès and Arthur Parent, Orpha and André Porrigniaux, Laure and Auguste Berger, Adolphe and Marthe Godart, Céline and Nestor Gerard and Maurice and Augusta Godart. There were 20 in the third generation, first cousins, of which Leon Beaujot of Kipling is the only survivor. In 1979, this family tree had six generations, 301 descendants and 122 spouses of descendants.

A stone cairn had been erected in 1940 to mark the site of the old church and cemetery, and remains visible on the Saint Hubert road, west off the Number 9 highway, on the north bank of the Pipestone valley.

The plaque that has just been erected stands on a steel gate that is visible from the road. To get closer one must cross the pasture which now occupies the site.

Source: Text revised from The Kipling Citizen 26 August 2000, p. 14 (see original for pictures taken by The Kipling Citizen). 


\section{Appendix 7.3 \\ Mike and Jeanne Mullie of Nipawin celebrate the $60^{\text {th }}$ Anniversary of their marriage: 28 December 1944}

The following is a slightly revised version of an article that appeared in The Nipawin Journal on 25 August 2004, pp. A9-10.

Note: The article included a picture showing, from left to right: Roland Mullie, Mary Mullie, Felix Mullie, Jeanne Mullie, Mike Mullie, Dorothy Beaujot and Leon Beaujot.

Some 120 friends and relatives gathered for the weekend of 6-8 August 2004 to help Mike and Jeanne Mullie celebrate their $60^{\text {th }}$ anniversary.

Relatives and friends had come from Nipawin, Arborfield, Zenon Park, Carrot River, Prince Albert, Bruno, Saskatoon, Regina, Rouleau, Langbank, Whitewood, Kipling, Flin Flon, Crystal City, Edmonton, Calgary, Toronto, London, 100 Mile House, Abbotsford and Earls Barton (United Kingdom).

Starting with a come-and-go afternoon at the Nipawin museum, the gathering continued with dinner at the Evergreen Centre, and for some it continued around a campfire in Nipawin Regional Park, with pancake breakfast at Mike and Jeanne's home the next day. Activities included picture taking by family group and generation, much eating and socializing, and for the younger set marshmallow Bailey's around a campfire.

Through the dinner and afterwards, we managed to find out about romance in the 1930s and 40s. We heard that social activities included ball games for both men and women, the others watching, skating, swimming, and dances. There was potential to buy wine or homebrew at these dances because the police were "quite far away;" these purchases would be hidden in the bush and sometimes bottles were confused, which could result in conflicts. Judging that there had been too much illegal drinking and conflict, the school board would close the dances until the young people made promises to be good -not unlike what happens with school dances in the $21^{\text {st }}$ Century.

There was some puzzlement regarding whether marriage proposals may have been made "between the sheets," as one nephew suggested or whether "you could not do things like that in those days," as Jeanne responded. Another puzzle was whether, after marriage, "going all the way" meant a long honeymoon trip to Regina.

Mike and Jeanne were more willing to discuss the visiting, since the 1930s, that took place across families that were spread out between Northern and Southern Saskatchewan. Julien and Marie-Louise Mullie (mother and stepfather to Jeanne née Leconte) had settled in Arborfield and Paul and Julienne Mullie (parents of Michel, now Mike) in St. Hubert (southeast of Whitewood). The six members of Paul Mullie's family had made the 300-mile trip with a Model A Ford in 1937. 
These visits continued into the next generations, with the trip taking place every year in one direction or the other between Arborfield and St. Hubert. The reunions inevitably bring back various forms of teenage behaviour, long after the original couples had become responsible parents, grandparents and great-grandparents. These visits also kept the generation of first cousins together. It also helps to have large families: there are 28 first cousins and now 51 second cousins and 10 great-grandchildren, all from four couples (two at St. Hubert and two at Arborfield).

At their farm, three miles from Arborfield, Jeanne was initially deprived of the electricity that she had enjoyed at the Julien and Marie-Louise Mullie home within the township of Arborfield. Even this early electricity had been limited, since it was based on a single generator in town that shut down at 10:00 pm. Mike was deprived of the telephone service that had come earlier to the district of St. Hubert.

Appreciating the benefits of telephone, Mike became President of East Addington Rural Telephone Service, which introduced a telephone service to Arborfield in 1958. The farmers got together, bought the posts, treated them themselves, bought the wire and phone boxes.

Originally people had only seen bears climb up on posts, but they became accustomed to it being Mike -the President become telephone repair man. He also became adept at diagnosing electrical shorts that could result from misplace nails, or dogs chewing at the wire. These shorts would bring down the whole system. Another hazard was lightning that could corrode the electrical system and reduce its efficiency, until the proper diagnosis and repair were done.

The 1950 arrival of electricity on the farm is also well remembered. It was so nice to have more than one light in the home, which had been possible on the basis wind charging a used six-volt car battery. Now there could even be electricity in the barn; this was a "god send" presenting much more ability to find the hay, to know where not to step, and to ensure that the milk hit the pail. Another early use of electricity was for a hair clipper, with Jeanne becoming the family barber. Young Armond was somehow very jumpy when this buzzing machine neared his ears, and he had to be bribed to undergo the operation with a handful of raisins, mixed with hair of course.

In these early days, the road would be closed to all but horses after the snowfall. Jeanne remembers that it was still dark as they set off for church in a caboose on Sunday morning, having bathed and clothed the children, milked and fed the cattle. As they went by other farms they could tell, from the lack of smoke emanating from certain chimneys, which neighbours were still in bed.

Also amazing in those days was how few things were purchased, a testimony of the varied productivity of farms, gardens, foraging and hunting, and of the small amount of money that was available to spend. On some shopping trips, the only food purchased was flour, sugar, salt, pepper, raisins, molasses, tea, coffee and possibly some canned beans. All else was produced at home and preserved for the winter.

Among all the stories, we must tell of the 1926 homebrew, which was hidden so well by Paul Mullie that it was only discovered in about 1960. Making homebrew had become illegal in about 1920. The dust storms of the 1930s had covered up the marker that had been made for the hiding place in a shelterbelt. Since a gallon of the potent stuff had been unearthed, Mike argued that he should inherit a quarter of 
the contents of the bottle. His brother Raymond argued that he was the rightful owner since he had purchased the quarter section, including the mineral rights. Mike nonetheless managed to obtain a Micky's worth. Mike now distributes the potent stuff in small teaspoons. His sister Dorothy finds that you can still get a buzz if you return the contents of the teaspoon to the bottle, and just lick the spoon.

Lack of space forces this account to a minimum for the decades of the 1960s, 70s, 80s and early 1990s, as farming modernized, and children left home. In 1985 Mike and Jeanne moved to Nipawin, where they garden within and beyond their lot of land, growing raspberries in the ditch just as Julien Mullie had done in the previous generation.

Mike continues to do much volunteer work for the Nipawin museum. Jeanne and Mike were awarded the Rays of Hope Award in 2003 from the Schizophrenia Society of Saskatchewan for their thoughtful volunteering and community building associated with the Oasis Drop-In Centre in Nipawin.

Rod Beaujot, nephew 


\section{Appendix 7.4 \\ Stories by the decade: Talks given by their children at Leon and Dorothy Beaujot's $60^{\text {th }}$ Wedding Anniversary, 14 July 2005}

\section{Adelin Warje-Beaujot:}

Now that we've had such a great supper, let us take a walk with Mom and Dad, we are calling this a "walk down memory lane."

I especially treasure the family story telling times, like we had last summer in Uncle Mike and Aunt Jeanne's living room, at the occasion of their $60^{\text {th }}$ anniversary celebrations. We heard about Dad and Uncle Mike being naughty teenage boys; they were not alone -- hiding alcoholic beverages below trees outside the dance hall. Disagreements could arise in identifying the right tree as darkness grew.

When Mom was young, the Mullie family was part of a beef ring. This was a way of sharing the meat from a cow, before fridges and freezers. Once on the weekly butchering, Grandpa Mullie, who was the epitome of conscientiousness, had forgotten that it was their turn to bring in the animal. An unexpected communication by horseback brought the family into line, and there was meat by the end of the day.

As I walk down memory lane, I see our family sitting around the kitchen table, always in our designated spots, all the lefties on one side, Jeanette (as the youngest) leaning her arm on Dad's shoulder at the head of the table, and Mom ready for the inevitable spill.

I see our whole family sweating it out together during the busy haying season - stacking up the hay rack and all riding home on top of the stack over and over again from the field to the barn. It felt so great to ride on top of that hay stack feeling the breeze and a sense of accomplishment.

I see all of us together, herding the cows to the north farm for a season, and back to our home pasture for the winter period. During the busy harvest season, Mom would pack a picnic supper to take out to Dad at the combine. Sometimes we would all eat out in the field. Mom was the chief fire fighter one day as some of us kids helped fight a grass fire. We managed to stop it before it got to the old grain barn.

Another time, I was helping Dad by fetching some gas for him from the farm gas tank. I was old enough but perhaps not smart enough - I brought him the wrong gas. He poured the liquid onto a pile in the garden and lit it. Poof! Next thing I knew, Dad was blown to the ground with fringed eyebrows. Then we sorted out the gases and I didn't make that mistake again.

I recall one particular April fool's morning when the Gatins were visiting for a few days. The night before, we kids had totally changed the location of everything in the kitchen cupboards. In the morning we sat and giggled at the breakfast table, watching Dad trying without success to set the table as he talked with the visitors. It took a while for him to realize that something fishy was going on.

An April fool's trick that we played on Mom was to hang a shoe on the cuckoo clock so that it would cuckoo at shorter intervals through the night. Mom could not believe how quickly the night had passed as she woke us up for school at 4:00 am, starting to pack our lunches. 
I am so thankful for your great parenthood, Mom and Dad: the balance of gentleness and discipline, the joys of family and community, and the many inspiring examples that you set for our lives.

So, now our walk down memory lane will continue with Rod speaking on Mom's life to marriage, Norbert on Dad's life to marriage, and the six others each speaking about a decade of their married life.

\section{Roderic Beaujot:}

Dorothée Mullie was born on 19 July 1917. Her parents, Paul and Julienne Mullie, were recent immigrants, farmers, in the French community of St. Hubert. They had arrived in Canada in 1911, just six years after the birth of Saskatchewan as a province, and within ten years of arrival they had established themselves with five children and three quarter sections of land. Dorothée was their fourth child, after Marie Louise, Jean, Raymond, but before Michel.

Let me skip ahead to school days. Dorothée Mullie, started school at the convent in St. Hubert. At the age of five she was boarding away from home during the week, coming home on weekends. It was a school for both girls and boys, but they were kept separate, and she had to speak with her brothers through a fence. The story that we remember best of Mom's early school days has to do with drinking water. The nuns had instructed that one should drink six glasses of water a day. When she was crying before the impossible task, her mother determined that the nuns had failed to explain that the six glasses did not have to be drunk at once. They had the numerator right, it was the denominator that needed more clarity.

The foolish separation of boys and girls, and the fact that the nuns were not necessarily trained as teachers, convinced the young family to continue the schooling at Golden Plain school. I don't want to take the punch from Mom's talk on Saturday (see Box 7.4), where she will speak on behalf of Golden Plain, but note how important this was. The Mullie children brought the school population from 3 to 7 , a full 130 percent increase, ensuring the viability of the school.

Adelin said that we should draw some lessons from this history. The lesson that I see is "don't look back". Carry the things that came before, don't abandon the French language and the Catholic community, but move forward to new things, and don't waste your time looking back.

Speaking of language, did you know that the language of interaction among youth of Mom's generation was English? I had always thought that my parents were an exception, in speaking this foreign language to each other, but English was the language at summer ball games and winter skating parties; it was at church that other languages were spoken, like French and Latin.

But Mom's life to marriage did not just involve family, school, church, ball games and skating parties, there was also work, much work. All available labour was put to work, in the house and outside of the house: cooking, gardening, preserving food, tending the orchard, tending the animals, working the fields. In fact, family and work were hard to separate; to be in a family was also to be part of its workforce. 
While the generation of the 1960s think we discovered inequality, already in the 1930s, Mom saw an unfairness in the division of work outside of the house. At harvest time, the boys got to collect the sheaves and bring them to the thresher, but she had to be in the dusty granary pulling the grain back into the bin, from an auger that made it just to the edge of the wall. A few years later, when she was again responsible for getting the grain into the granary, she made sure that the auger was long enough to reach the centre of the bin.

In her youth and young adult ages, Dorothy did many of the farm tasks. One story that I remember is of hitching up to a granary to move it on skids to a new location. This is a complex task, so much so that nowadays specialized workers come out to move buildings. But Mom was there alone, at the age of about 15 , backing up the horses so they would be close to the granary, making them stay still while hooking up, getting them to start slowly so as not to come away with only the skids, then moving directly toward the destination, keeping the horses from the fright of the strange creaking noises and the huge object following them. As she started out, she looked back but only saw a wall following her. Is this the lesson that Adelin wanted? People say that if you don't look back you will repeat the mistakes of yesteryear, but Mom says, look forward, all that you will see behind you is a wall.

The lesson is complex. While you should not spend your time looking back, you should make sure that you are carrying the granary forward. Don't forget from where you have come, don't abandon religion and community, and most certainly don't leave your children behind, but look forward, to new communities, new ways of doing things, and eventually it will be great-grandchildren following you.

\section{Norbert Beaujot:}

Léon Beaujot was born on 29 September 1919. His father Félicien Beaujot had come to the St. Hubert community at the age of 13 in 1892 and his mother Bertheline Sénéchaud had come in 1910. Félicien and Bertheline were married in 1910, and they first settled in the St. Hubert community, where their three children were born: Flora in 1911, Albert in 1912 and Léon seven years later.

Félicien suffered from very severe migraine headaches and a doctor had recommended that he would do better in a more humid climate. The family went to Freestone California (near San Francisco) in 1920 where they had an orchard and raised chickens. But this was the year of the Spanish flu, and Bertheline was near death at hospital; the youngest child was passed to a neighbour, who herself took sick and had to pass the child on to a third party. When the mother recuperated, it took some doing to recover Léon.

The family vowed that if they were to survive they would return to family and friends at St. Hubert, which they did in 1921. They farmed west of St. Hubert, then moved to the Handsworth district in 1927. It was during this time that Leon started school, in English immersion at Flinton, with one winter at Forget. Crop failures in the 30's brought a move to Amsterdam, north of Yorkton in 1934-35, but back to St. Hubert the next year. There are stories to fill a book, but one that is well remembered is Leon's bicycle trip in 1935, from Amsterdam to Handsworth, to help his brother-in-law. This was a 150-mile trip, and he had to retrace his steps a month later. 
I think that the reason the Beaujots moved so much, while the Mullies stayed put, was that Grandpa Mullie had a better still.

Leon and Dorothy were engaged at the beginning of the war. This is a lesson in patience for all of us, and in communication by letter, compared to the fast pace of today's relationships.

One of these letters was to be mailed on the occasion of a night out on the town in Vancouver. Three soldiers found themselves in Chinatown, but they did not remember much else, including whether the letter had been mailed. When Leon wrote to apologise to his fiancée for the lost letter, Dorothy devised the trick of writing letters while looking in the mirror. We had always thought that this was to avoid the inquisitive eyes of army command, but we now understand that it was Dorothy's gentle way of giving her fiancé heck for not remembering that he had mailed the letter before his escapade on the town. At first, Leon did not know what to make of these letters, but he did learn how to read them.

Dad was a coast guard outside of Victoria and Prince Rupert, then later he was in Sussex, New Brunswick, for commando training, as troops were being gathered to go overseas. But the war ended.

In my yard there are two trees that originally had stood apart and that have since grown together. Someone placed a 1945 licence plate between the trees, and they have since grown even more intertwined, sharing good years and bad ones, taking advantage of each other to brace themselves against stormy weather. With this image of the intertwined trees, I offer a wedding toast to this great couple who are my parents.

\section{Fred Beaujot:}

We are each supposed to have three minutes to talk; already Rod and Norbert have taken up most of the allotted time for all of us. So as usual, being the third child, I will try to make up the time.

1945-1955 - Wow! What a decade, and I have less than three minutes! This is going to be fast, so listen up!

Mom \& Dad got married on July 14th, 1945 -- what a coincidence that is 60 yeas ago today!

They started farming that year then in April 1946 Rod was born, they farmed some more and in February 1948 Norbert was born, they farmed some more and in September 1949 (on Dad's birthday) I was born. They continued to farm and in May 1951 Honory was born, they farmed a little more and in June 1952 Leona was born. Everything was going well, they continued farming and in April 1954 Doreen was born. They farmed some more, Mom was pregnant in 1955 but it was not until the next decade, in January 1956, that Adelin was born.

That is it, you get the picture; it was a decade of farming and babies!

My three minutes are almost up, but I have a few more notes from that decade if you will give me a little more time. 
They bought the farm in 1944, before they married, for $\$ 23$ an acre; a half section that we now call the north farm. They also had a half dozen cows and horses. They have always kept very detailed account books; in the first year, total expenses were $\$ 871.99$, income was $\$ 1,364$. The numbers seem small, but from a banker's perspective, that is a very good return rate for the first year of business.

In 1948 they bought their first tractor and retired the horses. It was an Oliver, for \$1,350. Dad also bought a sprayer that year for $\$ 222$ and a 45 -gallon drum of 24D for $\$ 467$. Imagine that, 24D! and he did a lot of custom spraying with that equipment.

In 1949 they bought their first combine for $\$ 1,700$.

In 1950 the books indicate that is when they started using a lot of fertilizer. The income side of the books indicate that they had a purebred boar and they were hiring it out to breed sows at $\$ 2.50$ a shot. Also, on the income side; more custom spraying and swathing. Interesting to note they spent $\$ 292$ for 964 gallons of tractor gas in that year. That works out to about 6 or 7 cents a litre.

In 1952, Uncle Albert helped build the extension on the house. Those are some of my oldest memories of Uncle Albert asking me to go around and pick up nails and take them back to him. I think that is also when I developed a taste for eating dirt, I still eat it now at work, but they don't call it dirt.

In 1954 Saskatchewan Power came to the farm. That was an expense of $\$ 480$.

This decade was also filled with family memories; some of which were not covered by Adelin. Church on Sundays, our cousins down the mile, and every year visiting our cousins from Arborfield. The Driscolls: Anti Flora, Uncle Joe, and cousins Joe, Bertha, Monica, Jack, Leon and Bernice who was the only one younger than me. They had lots of horses; I remember being scared of horses back then. I learned how to be an uncle in those days from my favourite uncles: Uncle Albert and Uncle Mike.

Thanks Mom and Dad for a terrific decade for me to start my life.

\section{Honory Beaujot:}

During the 10 years from 1955 to 1965 Leon and Dorothy continued to try and fill the addition to the house by adding Adeline, Patrick and Jeanette to the family for a final total of 9 over 20 short years. These 10 years also saw the elder kids move into their teenage years. Life should be so good.

Other significant events of these 10 years:

In 1960 the country schools were closed, and all the kids were sent to the big city of Langbank. This at first worked out good as the horse and buggy bus was replaced by a regular yellow school bus. But someone overlooked the Saskatchewan winters and many days big yellow couldn't get to the Beaujot farm and the Beaujot kids were spending lots of school days at home. In the interest of getting the kids out of the house, and with his strong dedication to education, Dad with the help of his open-air tractor took on the job of official snow blower for the community. Opening roads kept Dad out of the cozy 
warm house during the winter months, which likely contributed to the reduction in the birth rate. Catholic-approved birth control.

In 1960 Mon and Dad decided that they had the resources to expand the farm, so they went out on a limb and purchased another $3 / 4$ section of land, more than doubling the size of the operation. All that cheap labour was beginning to bear fruit.

In 1961 they decided that something had to be done about spending the winters out of the house plowing snow, so he came up with a unique solution. Move the house to the newly purchased farm where the roads were built up. The moving contractor charged only $\$ 800$ to move the house 5 miles. The neighbours and teenagers who helped were not as well compensated. A significant event regarding the house move was when the municipality decided that a bridge was not strong enough for the weight, requiring a detour through the creek. Guess what? The house got stuck! If it wasn't for extra power from farm tractors, and a few prayers from Mom, the Beaujots would have become river dwellers.

In 1962 technology caught up with Mom and Dad and they bought their first TV. Can you imagine 8 kids in the house with no TV. The old black and white snowy-pictured TV with one channel was all that was needed to keep the kids occupied enough such that Jeanette could be conceived.

I don't know what year it was, but it was near the end of these 10 years that Mom told us her first "dirty" joke. I'll never forget it.

"There was this man that went to the doctor with severe constipation. The doctor gave him a box of suppositories and told him to come back in a week. When he returned the doctor asked him how the suppositories worked. The man was quite upset and said "for all the good these did, I might as well have shoved them up my ass"

Dad never did find out that Mom used to tell us dirty jokes.

\section{Leona Fry:}

1965 to 1975 - These were very busy years for Mom and Dad: for a large part of this time they had up to eight children at home. They saw many changes happening in the world and in the family. In the world it was a time filled with significant social changes: the hippie era, Woodstock, landing on the moon, Martin Luther King's assassination, university riots, the Cold War, you name it. They went through it all while continuing to tend the farm and raise a family. There were also significant changes in the Beaujot demographics in these ten years. At the beginning of the decade with eight children at home they were still changing diapers, wiping noses and settling scraps and by the end there were only two children left at home and several grandkids on the way. During these ten years Mom and Dad made 8,740 lunches.

Education was very important. Two things stand out in my mind. One, in 1965 they purchased a senior and a junior set of the Encyclopedia Britannica. We spent many hours browsing through these looking for ideas and information for the many speeches and essays that had to be written for school. And two, 
travelling to different places was very educational. In 1966 we travelled to BC, a tent trailer and six kids in tow. We learned what mountains are. In 1967 we travelled across Canada in the other direction to Montreal to go to Expo 67 where Rod was working for the summer. We went to see the Plains of Abraham and to this day Adelin is still convinced that she didn't see any planes. "I don't see any planes." she said to Mom and Dad. Honory mentioned that Mom taught us how to tell dirty jokes. Well, on this trip they also taught us how to swear. At Expo the car park was divided into sections labelled with the names of animals in French along with their picture. Of course, we parked in the "seal" section, in French called "phoque". After a long day on the grounds we were looking for our car. Someone yelled, "Oh PHOQUE there it is!"

Thank you, Mom and Dad, for the fun education, for instilling in us a sense for travel, for showing us the bigger world, and for all those many sandwiches. We love you!

\section{Doreen Gardner:}

1975-1985 - The Nest Empties.

Mom and Dad were finally able to spend some of their hard-earned money on themselves. So, in 1976 they treated themselves to a trip to Europe, taking Dad's sister, Flora, with them. While visiting France and Belgium, where the custom is to kiss on each cheek every morning, Dad and Aunt Flora, though they loved each other very much, were going to have no part of this, thinking that a simple hand shake would do.

Their next great excursion was to Argentina for Honory and Deanna's wedding in 1982. Touring other countries in South America, including Brazil, Jeanette tells the story of being warned to stay out of the long grass because of large snakes. Each morning Mom and Dad would wake up to find Jeanette sleeping at the foot of their bed.

Mom and Dad were both very involved in their parish. In 1980 when St. Hubert got together to make a History Book for the $95^{\text {th }}$ anniversary of the parish, they both took great interest in the project.

In June of 83, Mom packed the last of 21,000 or so school lunches. She wanted it to be a special one, and Jeanette realized how special it was when she opened her thermos. Mom had forgotten that the left-over slush from the freezer contained vodka.

So now after 37 years of raising a family, it was just the two of them. But their family was still growing! From 1975 to 1985, they gained two sons-in-law, one daughter-in-law, and eleven grandchildren.

In these ten years, Mom and Dad were blessed with good health, prosperous crops, and seeing the results of all their hard work through the years. 


\section{Pat Beaujot:}

Mom and Dad, I love you. I love the example you have set for us.

1985 to 1995 were early retirement years. At the young age of 67 they sold the farm and bought a fifthwheel camper to travel far and wide.

In October they crossed Canada to Maritimes visiting along the way. While camped in Nova Scotia, they talked with a lady who was walking her dog. As they visited longer, it turned out that the couple was from Nova Scotia and they were headed to a trailer park in Orlando, Florida. She suggested that they check it out when they get there. Dad and Mom followed the Eastern seaboard, stopping in New York for a tour and went up the World Trade tower. They found the trailer park in Orlando and the first people they saw there were the couple from Nova Scotia.

The next winter they went to Texas since most western Canadian snowbirds go to Texas and Arizona. Next summer they took the $5^{\text {th }}$ wheel to Yukon and Alaska.

No moss was growing on this $5^{\text {th }}$ wheel. They spent the next 8 winters in Orlando Florida going by truck, car and train. The second time they were there, they rekindled their love for baseball and watched the Blue Jays during their spring training in the Grapefruit League. Three or four carloads of Canadians would load up for each Blue Jay game. It was here that Mom and Dad learned about tailgate parties. They made many new friends. They were visited in Florida by Rod and Liz, Fred and Karen, Jeanette and the boys.

With this expert advice, the Blue Jays won the 92 and 93 World Series. But there were other important events in this decade: They built a house and moved to Kipling, where again they made many new friends. Their first great-grandchild was born, Brittany. In 1994 they travelled to England to visit Annette and tour of Scotland. In 1995 they travelled to Argentina to greet the arrival of Melissa, their 9th granddaughter.

Besides all this, Dad and Mom helped immensely on the farm every spring and fall.

Two lessons learned in this decade: Never too old to make friends. Best coaches the Blue Jays have ever had.

Jeanette Beaujot:

1995 - Present

When I sat down to write this I soon realized that Mom and Dad have been very busy for the past 10 years. I have the privilege of having lunch with Mom and Dad every weekday and quite often they leave me notes saying that they are away visiting friends or relatives in another town, or that they are off to the city for the day, or they were playing cards with the neighbours. They travel great distances east, 
west, north and south to see relatives. They are always on the go. I think this is how they have kept so youthful.

In the spring Mom and Dad travel east or west across Canada to see family. They return with lots of stories to tell and pictures to share. When they get settled back home it is usually time to start seeding the vegetable garden. Mom still holds the record for having the first radishes out of the garden in the spring. I remember the first radish sandwiches in school lunches. Mom also makes dandelion salad, but the salads are getting smaller, she can't seem to find enough dandelions in their yard. Obviously, she has not looked in Langbank. They always make time to sit down and watch the Blue Jays baseball games on TV, keeping us all up to date on the game scores and statistics. A few years ago, Mom and Dad went on a bus tour to Minneapolis to watch a few Blue Jays games. Mom was the oldest fan on the bus.

In the summer you can usually see Mom and Dad driving around the countryside checking the crops. Not that long ago someone asked me if Dad misses farming, commenting on what a skilful farmer he was. I responded that I am sure he does miss it but now he puts all of his effort into their lawn, which looks and feels like a well manicured carpet. Mom is usually out doing what she cannot resist doing, which is weeding. I am sure that she can spot a weed from across the yard. She always takes time to appreciate the flowers, picking some for bouquets to enjoy in the house.

In the fall they enjoy travelling to Pat \& Judy's, Norbert \& Sam's and Doreen \& Dean's farms to observe the combining, sometimes making a rushed trip to a nearby town or the city for a desperately needed part. After they have harvested their vegetable garden and prepared the yard for winter, they travel to see family on the side of Canada opposite to where they had gone in the spring. Mom and Dad really treasure these times of visiting with their family that live further away. When they arrive back home, winter is setting in and you can find them at home a bit more often. Dad enjoys snow blowing the driveway even when there is just a skiff of snow. They watch countless curling games on television. Mom has finished many beautiful cross-stitch projects while watching the games.

For the past several years Dad has taken on a part-time job. He averages about 16 hours per week driving people who are not able to drive themselves to Regina for medical visits. The pay is not that good, but it is a fulfilling job and he enjoys talking with people along the trip.

In closing I would like to say that Mom and Dad have always been there for me, they have always been there for all of us and for each other:

Listening

Giving Advice

Consoling

Laughing

And enjoying life

I love you Mom and Dad. 


\section{Appendix 7.5}

\section{Email Exchanges in the family at the time of Dorothy's decease, 4-6 March 2014}

Jeanette, 4 March 12:49 PM

Hi everyone,

Doreen just got a call from Lori at the care home. Mom is very lethargic today and her heartbeat is weak. Lori will call if anything changes. Doreen \& I will likely go tomorrow morning.

Blessing,

Jeanette

Norbert, 4 March 12:54 PM

We are planning a trip to visit Thursday morning, so you can let Mom and Dad know.

Thanks,

Norbert

Honory, 4 March 7:29 PM

Just talked to Dad. Mom hasn't eaten all day and drank very little.

They were just coming in to try again.

Deanna just left for Buenos Aires for a quick 2 week visit; she got sick of the cold.

Honory

Rod, 4 March 8:03 PM

$\mathrm{Hi}$, I got much the same information as Honory. Doreen had called (or was it Leona?). Dad was happy to hear that Doreen and Jeanette were coming tomorrow, and Norbert the next day.

Dad felt that the staff had done the right things, getting instructions from the doctor.

He was hoping that Mom would eat tonight, her hands and feet were particularly cold. He was

wondering why they had not taken her blood pressure but felt they probably had a different

way of knowing her blood pressure.

Rod

Jeanette, 4 March 8:45 PM

It was Doreen who had called to talk with Dad. Mom's circulation was not good yesterday either when we were there, her hands and feet were quite cold. The staff are trying to feed Mom, so Dad feels better that they're attempting to give her something to eat, but she is not responding. I will call Lori 9:30 am and see how they are before deciding to head to Weyburn.

Jeanette

Bernice, 4 March 9:11 PM

Sorry Just got in from Ralph's funeral and picked up these emails.

Have a couple kids here tonight but can go up at $8 \mathrm{am}$. Please call

my cell if you get a call and I will go right up. 
Bernice

Leona, 4 March 9:16 PM

Hi All,

I did talk with Dad this afternoon. That is probably why he didn't

know if it was Doreen or me. It was both.

Dad is appreciating all the calls.

Leona

Jeanette, 5 March 4:47 PM

I talked to Dad this afternoon. He has spent the day sitting in the

wheelchair by the bed holding Mom's hand and talking to her. He said she

hasn't opened her eyes or said anything and hasn't been able to drink.

Dad is appreciating all the calls but wants someone there with them. I told him Norbert will be there tomorrow morning and I will be there right after lunch. He said he wasn't sure how long Mom will hold on. I will pack a bag in case I need to stay the night tomorrow.

Jeanette

Pat, 5 March 6:09 PM

I will pack an overnight bag and head down there in an hour or less.

Pat

Rod, 5 March 6:12 PM

Great to hear that Pat is on his way to Weyburn.

Thanks so much for those reports, Jeanette. It is especially helpful that you and Doreen are in contact with Lori.

I just talked with Dad. Mom is spending her time lying down, Dad stays with her, is with her all the time, rubs her back and tries to talk with her. Today she said very little, which Dad sees as a change, it is the first time that she is so unresponsive and not saying anything.

The staff have explained that they cannot feed Mom for fear that she would choke. Dad does not think she can live very long this way. But, he understands that the staff are doing what they can. When I said that it would not serve much purpose to feed Mom through intravenous, Dad much agreed. When I said that Mom's body is probably just closing down, Dad also thought this was a good way of seeing things. He observed that Mom is not suffering too much, but she will probably not get any better.

Dad would like to have someone there to visit. I explained why Jeanette and Doreen did not come today (he agreed that there was quite a blizzard in the morning), and that Norbert would come tomorrow. I said that we would consult with Norbert, Doreen and Jeanette to know when it is best to come down, but we will for sure come before very long.

I also told Dad that Bernice had been in Hawaii for 10 days, with Jack \& Marie and Leon \& Linda, and that she went to Ralph Jordon's funeral afterwards, so she is just now back in Weyburn.

Blessings, Rod 
Pat, 5 March 8:38 PM

I am at Hill Top now. Bernice's experience is telling her this is the

beginning of the end. Mom is laying very peacefully breathing steady.

Apparently nothing has gone in or out of her body for a while now. Bernice

says it could be an hour or a week, but Mom will likely not rally back. Dad

understands and is accepting it well. He does forget sometimes though.

I will stay here till around 9 or till Norbert gets here if he comes earlier.

We're having a beer watching hockey till curling starts.

Love, Pat

Norbert, 5 March 8:56 PM

We plan on being there close to 9 if the weather is not too bad. Lots

of loose snow and snowing so if it is windy it will be hard driving.

Norbert

Doreen, 5 March 9:09 PM

Norbert, maybe tomorrow you should ask about having the priest come by.

God bless, Doreen

Rod, 5 March 9:37 PM

Great that Pat can stay till the morning, and that Norbert will be there

tomorrow, as well as Jeanette. Thanks, Pat, for sending all those updates.

Blessings, Rod

Pat, 5 March 10:31 PM

The Priest just left, Dad is back in bed. Dad was very appreciative to

have the priest come and give Mom her Last Rites. It was beautiful, Dad

held her hand as the priest did his readings. I took a picture and may be able

to share it later tonight.

Pat

Pat, 6 March 2:27 AM

Mom took her last breath at 1:42, she didn't suffer at all. Dad is up and doing well.

Pat

Rod, 6 March 3:48 AM

Hi Pat,

The news makes me very sad, but it is so good to know that you were able to be there so that Mom and Dad were not alone in these last moments together.

Blessings that Mom is in a better place, that she died in peace, surrounded by loved ones.

I am looking into flights to bring me to Regina later today.

Love, Rod 
Jeanette, 6 March 6:48 AM

Pat thank you for being there with Mom \& Dad last night.

Norbert do you know about how long you'll be there today? I will go to be with Dad after.

Jeanette

Honory, 6 March 7:20 AM

Thanks Pat for all you did, it was a blessing that you were able to be

there, especially for Dad; big hug for Dad from all of us. It looks like we

are in for snow here today so I might fly instead of driving, but in any

case, I should be able to get there today.

Honory

Pat, 6 March 7:28 AM

I feel blessed to have been able to be here. Dad and I got some sleep on the couches in the common room. We're up having coffee. Dad is doing really good.

Pat

Adelin, 6 March 9:55 AM

Blessings to all. Thank you everyone, for such a caring surround for Mom's departure. I was awake much of the night. I guess that's why.

I'll phone Leona to perhaps coordinate a flight together with her and let you know from there.

Adelin

Fred, 6 March

Hi All,

I've been reading all these exchanges and it nice to know that everyone is there in some way. Very sad but it is nice that Pat and Dad were present, and that Bernice was able to get hold of the priest. And I'm sure Jeanette and all of us passed on some very nice blessings as well.

Rod, let me know what your options are for flights. We may be able to connect. Karen is in Port Elgin until tomorrow afternoon.

Fred

..........................

Bernice, 6 March

My condolences to you all.

Your mom is in a better place.

However I can help, please let me know.

Bernice 


\section{References}

Anderson, Alan. 2013. Settling Saskatchewan. Regina: University of Regina Press.

Anderson, Alan. 2017. French Settlements. The Encyclopedia of Saskatchewan. Available at: http://esask.uregina.ca/entry/french settlements.html

Anderson, Alan. 2017b. Personal communication in e-mail dated 8 March 2017.

Balon, Howard and Hubert Boutin. 1980. Knights of Columbus: Whitewood - St. Hubert 6362. Pp. 18-19 in Memories of St. Hubert 1980.

Barry, Bill. 1999. First Nations and Treaties 1871-1906. Pp. 44-45 in Ka-iu Fung (Editor), Atlas of Saskatchewan. Saskatoon: University of Saskatchewan.

Barry, Lisa. 2019. Doctrine of Discovery: Stolen Lands, Strong Hearts. Documentary produced by Anglican Video.

Bartley, Allan. 2021. The Ku Klux Klan in Canada: A Century of Promoting Racism in the Peaceable Kingdom. Formac Publishing.

Briere, Karen. 2009. Historic barn rises from rubble. The Western Producer, 3 September 2009. Available at: http://www.producer.com/2009/09/historic-barn-rises-from-rubble/

Beaujot, Albert. 1980. Albert Beaujot. Pp. 60-61 in Memories of St. Hubert 1980.

Beaujot, Dorothy. 1980. The History of the Church. Pp. 9-15 in Memories of St. Hubert 1980.

Beaujot, Leon. 1980. Felicien and Bertheline Beaujot. Pp. 59-60 in Memories of St. Hubert.

Beaujot, Roderic. 2000. Earning and Caring in Canadian Families. Peterborough: Broadview Press.

Beaujot, Roderic and Elisabeth. 1979. The descendants of François and Justine Beaujot in Belgium and Canada. Langbank: Beaujot.

Beaujot, Roderic and Kevin McQuillan. 1982. Growth and Dualism: The demographic development of Canadian society. Toronto: Gage.

Boyden, Joseph. 2013. Louis Riel and Gabriel Dumont. Penguin : Extraordinary Canadians.

Byers, Daniel. 2016. Zombie Army: The Canadian Army and Conscription in the Second World War. Vancouver: UBC Press.

Cameron, Derek, 2020. University of Saskatchewan research on Spanish flu teaches lessons about pandemics. Research Stories: Social Sciences and Humanities Research Council, 17 July 2020. 
Canada, Government of. 2017. From a single seed - Tracing the Marquis wheat success story in Canada to its roots in Ukraine. Agriculture and Agri-Food Canada: Scientific Achievements in Agriculture.

Canadian War Museum. 2020. The Aleutians Campaign, 1942-1943. Available at: https://www.warmuseum.ca/cwm/exhibitions/newspapers/operations/aleutian e.html

Carter, Sarah. 1990. Lost Harvests: Prairie Indian Reserve Farmers and Government Policy. Montreal \& Kingston: McGill-Queen`s University Press.

Carter, Sarah. 2020. Indigenous Reserve Agriculture to 1900. Indigenous Saskatchewan Encyclopedia. See: https://teaching.usask.ca/indigenoussk/import/indigenous reserve agriculture to 1900.php

CBC News, 2009, Saskatchewan town parlays paper clip fame into film deal. January 27, 2009. See: https://www.cbc.ca/news/entertainment/saskatchewan-town-parlays-paper-clip-fame-into-film-deal1.862449

Coneghan, Daria. 2017. Charles Saunders. In Encyclopedia of Saskatchewan. Available at: http://esask.uregina.ca/entry/saunders charles 1867-1937.html

Crosby, Alfred W. 2003. America's Forgotten Pandemic: The Influenza of 1918. Cambridge University Press.

deBeaudrap, Pete. 1980. Count deBeaudrap Family. Pp. 87-88 in Memories of St. Hubert.

Denis, Sister M. 1980. Joan of Arc Nursing Home. Pp. 20-22 in Memories of St. Hubert 1980.

Department of National Defence (Canada). 1944. Financial regulations and instructions for the Canadian Active Service Force (Canada). Ottawa: Edmond Cloutier, Printer to the King's Most Excellent Majesty.

Discover France. 2017. Paris climate - Weather records. Available at: http://www.discoverfrance.net/France/Paris/Paris climate.shtml

Driscoll, Flora. 1980. Joe \& Flora Driscoll. Pp. 96-97 in Memories of St. Hubert 1980.

Driscoll (Beaujot), Flora. 1992. Memories. Calgary: Driscoll.

Duthoit, Gaston. 2014. Personal communication dated 9 May 2014.

Dubé, Albert O. 1999. La Rolanderie revivra-t-elle? Revue historique 10(1). Available at : http://musee.societehisto.com/la-rolanderie-revivra-t-elle-n182-t1221.html

Dumonceaux, Sylvain. 2020. Telephone conversation on 15 April 2020.

Dunand, Edmond. 1980. Memoirs of Edmond Dunand. Pp. 217-218 in Memories of St. Hubert 1980.

El Dorado Weather. 2017.Moosomin Saskatchewan Canada Climate Data. Available at: http://www.eldoradocountyweather.com/canada/climate2/Moosomin.html 
Fireside Film Company. 2009. Leon \& Dorothy. www.FiresideFilmCompany.com. The film is available on Youtube by searching for "youtube \& Leon Dorothy": https://www.youtube.com/watch?v=d$\underline{\text { sHPUze4Go }}$

Flick, Henry. 1980. Hamlet. Pp. 31-33 in Memories of St. Hubert 1980.

Foster, John. 2015. Buffalo Hunt. The Canadian Encyclopedia. Available at: http://www.thecanadianencyclopedia.ca/en/article/buffalo-hunt/

Fowke, Vernon C. 1957. The National Policy and the Wheat Economy. Toronto: University of Toronto Press.

Francis, R. Douglas and Chris Kitzan. 2007. The Prairie West as Promised Land. Calgary: University of Calgary Press.

Frémont, Donatien. 2002. Les Français dans l'Ouest Canadien. 3rd Edition. Saint-Boniface : Les Éditions du Blé.

Gauvreau, Danielle, Patrick Sabourin, Samuel Vézina and Benoît Laplante. 2018. The mechanics of the baby boom : Unveiling the role of the epidemiologic transition. Population Studies 72(3): 305-321.

Gatin, Emile. 1980. Adolphe Gatin. Pp. 110-112 in Memories of St. Hubert.

Gatin, Victor. 2017. Personal communication dated 7 August 2017.

Guest, Dennis. 2013. Family Allowance. The Canadian Encyclopedia. Available at: https://www.thecanadianencyclopedia.ca/en/article/family-allowance

Guitard, Michelle. 1977. La Rolanderie. Saskatchewan History 30(3): 110-114.

Haggarty, Liam J. 2013. Métis Economics: Sharing and Exchange in Northwestern Saskatchewan. Pp. 205247 in Christopher Adams, Gregg Dahl and lan Peach (Editors), Métis in Canada: History, Identity, Law and Politics. Edmonton: University of Alberta Press.

Hall, David. 2007. Clifford Sifton's vision of the Prairie West. Pp. 77-100 in R. Douglas Francis and Chris Kitzan. 2007. The Prairie West as Promised Land. Calgary: University of Calgary Press.

Hawkes, John. 1924. The Story of Saskatchewan and its People. Chicago \& Regina: S.J. Clarke Publishing.

Hedsman, Roy. Editor. 1988. St. Hubert. Pp. 131-134 in Archdiocese of Regina: A History 1910-1985.

Regina: Archdiocese of Regina.

Humphrys, Ruth. 1978. Dr Rudolf Meyer and the French Nobility of Assiniboia. The Beaver, Summer 1978: 17-23.

Hewlett, A.E.M. 1954. France on the Prairies. The Beaver, March 1954: 3-7. 
Innes, Robert Alexander. 2018. Historians and Indigenous Genocide in Saskatchewan. Posting on shekonneechie.ca. See: https://shekonneechie.ca/2018/06/21/historians-and-indigenous-genocide-insaskatchewan/

Jaenen, Cornelius J. 2011. Promoters, Planters, and Pioneers: The Course and Context of Belgian Settlement in Western Canada. Calgary: University of Calgary Press.

Jeannot, Eileen and Joe Jeannot. 1980. The Choir. P. 17 in Memories of St. Hubert 1980.

Johnson, W.E. and A.E. Smith. 1986. Indian Head Experimental Farm, 1886-1986. Regina : Research Branch, Agriculture Canada Historical Series no 23.

Journées du patrimoine. 2014. Une noblesse française à la Rolanderie. Available at : http://www.journeesdupatrimoine.ca/opFichier/une-noblesse-francaise-a-la-rolanderieMEVBHv553v27-9908.pdf

Jutras, Mathilde. 1995. La grande nostalgie: French-Speaking Women and Homesickness in Early Twentieth-Century Saskatchewan. Pp. 41-59 in David De Brou and Aileen Moffatt, Editors, "Other" Voices: Historical Essays on Saskatchewan Women. University of Regina: Canadian Plains Research Centre.

Kerr, Don and Roderic Beaujot. 2016. Population Change in Canada. Toronto: Oxford University Press.

Kipling Citizen, 2000. Plaque, gate marks old St. Hubert parish cemetery. Kipling: The Citizen, 26 August 2000, p. 14.

Kipling and District History Book Committee. 1998. Lansdowne School District \#56. Pp. 117-118 in Pioneers and Progress: Kipling and District 1882-1998. Altona, MB, Friesens Publishing.

Klein, Susan, 2017. Personal correspondence, dated 10 May 2017, from archives of the Roman Catholic Archdiocese of Regina.

Laforge, Arthur. 2017a. Ahnentafel Chart of Marie Josephine "Julienne" Smets. Dated 6 March 2017. Laforge, Arthur. 2017b. Modified Register for Henri Smets. Dated 6 March 2017.

Laforge, Cyril. 2009. Page one translation from Dutch to English RE: Smets. E-mail dated 1 February 2009. Laforge, Cyril, 2020. Personal communication dated 6 July 2020, as retired Regional Farm Business Management Specialist, Sask Ministry of Agriculture.

Laforge, Julia and Robert McLeman. 2013. Social capital and drought-migrant integration in 1930s Saskatchewan. The Canadian Geographer 57(4): 488-505.

Langbank and District History Committee, 1984. Langbank Memories. Altona, Manitoba: Friesen Printers. 
Lapointe, Richard and Lucille Tessier. 1986. Historie des Franco-Canadiens de la Saskatchewan. Regina : La Société historique de la Saskatchewan.

Lapointe, Richard and Lucille Tessier. 1988. The Francophones of Saskatchewan - A History. Campion College: University of Regina.

Lavergne-Smith, Nicole. 2016. Sur la trace des contes à Whitewood. Ici Radio-Canada Saskatchewan, 26 August 2016. Available at : http://ici.radio-canada.ca/nouvelle/799173/comtes-francais-whitewoodrolanderie-aristocrates-hubert

Leclair, Therese. 2017. Personal communication dated 13 August 2017.

Le Dressay, Reine. 1980. Joseph Cottin Family. Pp. 77-81 in Memories of St. Hubert 1980.

Le Dressay, Reine, Betty McCormick and Father L'Heureux. 1980. Liturgical Changes. P. 16 in Memories of St. Hubert 1980.

Léonard, Carol. 1987. La Rolanderie : Rapport sommaire d'une recherche sur les débuts de Saint-Hubert en Saskatchewan et sur son aristocratie locale. Regina: Association culturelle franco-canadienne de la Saskatchewan.

Léonard, Carol. 1999. Au pays des comtes. Revue historique 10(2). Available at: http://musee.societehisto.com/au-pays-des-comtes-n183-t1224.html

Lesthaeghe, Ron. 2016. The Decline of Belgian Fertility, 1800-1970. Princeton University Press.

Lesthaeghe, Ron. 2017. Personal communication on "Agricultural crisis of the 1880s" dated 8 February 2017.

Macdonald, 1966. Canada: Immigration and Colonization, 1841-1903. Great Britain: Aberdeen University Press.

McCourt, Edward. 1968. Saskatchewan. Toronto: Macmillan of Canada.

McIntyre, Mike. 2007. Sharp-eyed farmer brought about boys' rescue from pedophile. Ottawa Citizen, 25 July 2007.

McIntyre, Mike and Bonnell, Keith, 2009. House of horrors burned for TV film. Winnipeg Free Press, 12 March 2009.

Marchildon, Gregory. 2009. The Prairie Farm Rehabilitation Administration: Climate Crisis and FederalProvincial Relations during the Great Depression. Canadian Historical Review 90(2): 275-301.

Marchildon, Marie Asselin, with Louise Mullie, 1989. Ce n'est qu'un au revoir. Privately published.

McClement, David M. 2017. From Peat Bogs to Prairie Sod: A Saga of Two Families. Self-published by d.m.mcclement. 
McClinton, Blair. 2017. Summerfallow. The Encyclopedia of Saskatchewan. Available at: http://esask.uregina.ca/entry/summerfallow.html

McCormick, Betty. 1980a. St. Hubert School No. 2770. Pp. 23-25 in Memories of St. Hubert 1980.

McCormick, Betty. 1980b. Rural Municipality of Silverwood No. 123. Pp. 26-29 in Memories of St. Hubert 1980.

McLennon, David. 2008. Our towns: Saskatchewan Communities from Abbey to Zenon Park. Regina: University of Regina Press.

McLennon, David. 2017. Whitewood. The Encyclopedia of Saskatchewan. Available at: http://esask.uregina.ca/entry/whitewood.html

Metzler, Boyd. 2017. Personal communications dated 3 February 2017 and 27 July 2017.

Meyer, Rudolph Hermann and Gabriel Ardant. 1887. La question agraire : Étude sur l'histoire politique de la petite propriété. Paris : Morot Fils. As cited in Sullivan, 2009: 260.

Memories of St. Hubert 1980. Betty McCormick, Editor. Printed by The Whitewood Herald, Whitewood, Saskatchewan on behalf of the Parish of Saint Hubert.

Ménage, Martin. 2020. Personal communication dated 24-25 August 2020.

Molton, Jocelyn. 2017a. Personal communication dated 1 March 2017.

Molton, Jocelyn. 2017b. Personal communication dated 12 November 2017.

Moon, Parker Thomas. 1921. The Labor Problem and the Social Catholic Movement in France. New York: MacMillan.

Mooney, Elizabeth. 2017a. Rupert's Land Purchase. In Encyclopedia of Saskatchewan. Available at : http://esask.uregina.ca/entry/ruperts land purchase.html

Mooney, Elizabeth. 2017b. Dominion Land's Act / Homestead's Act. In Encyclopedia of Saskatchewan. Available at :http://esask.uregina.ca/entry/dominion lands act homestead act.html

Mullie, Bernard. 1995. La guerre aérienne de 39-45 : Le témoignage de M. Bernard Mullie sur un avion allemand tombé aux Loges en juin 40. Courrier Cauchois, 5 août 1995 pp. 9-10.

Mullie, Jean. 2016. Histoire et généalogie de la famille Mullie et de ses alliances. www.lulu.com

Mullie, Jean. 2019. Histoire et généalogie de la famille Mullie depuis 1435. www.lulu.com

Mullie, Jos. L.M. 1963. Les Descendants de Desmulliers-Delfaille de Marcq-en-Baroeul. Leuven: Drukkerij Caeyers.

Mullie, Maria. 1980. Entertainment. Pp. 33-34 in Memories of St. Hubert 1980. 
Mullie, Pierre. 2004. Noces d'Or. Text written by Pierre Mullie at the occasion of his golden anniversary in 2004, 30 pp.

Musée Virtuel Francophone de la Saskatchewan. 2017a. Saint-Hubert. Available at: http://musee.societehisto.com/saint-hubert-n381-t643.html

Musée Virtuel Francophone de la Saskatchewan. 2017b. Noblesse et prairie. Available at: http://musee.societehisto.com/noblesse-et-prairie-n384-t400.html

Neary, Peter. 2011. On to Civvy Street: Canada's Rehabilitation Program for Veterans of the Second World War. Montreal \& Kingston: McGill-Queen's University Press.

Nestor, Rob. 2017. First Nations Land Claims. The Encyclopedia of Saskatchewan. Available at: http://esask.uregina.ca/entry/first nations land claims.html

Padbury, G.A. and D.F. Acton. 1999. Ecoregions of Saskatchewan. Pp. 160-162 in Ka-iu Fung (Editor), Atlas of Saskatchewan. Saskatoon: University of Saskatchewan.

Palmer, Potter. 1893. World's Columbian Exposition -- Official Catalogue of Exhibits: Woman's Building. Chicago: W.B. Conkey Co.

Payot, Mathilde. 1980. Eugene Beaujot. Pp. 57-59 in Memories of St. Hubert.

Payot, Mathilde and Leon Beaujot. 1980. Francois and Justine Beaujot. P. 57 in Memories of St. Hubert.

Payot, Rose. 2017. Personal communication dated 9 July 2017.

Pugh, Garth. 2006. St. Hubert Mission. The Canadian Encyclopedia. Available at: http://www.thecanadianencyclopedia.ca/en/search/?keyword=St\%20hubert\%20mission

Pulla, Siomonn P. 2013. A brief social history of the development of Métis political organization in Canada, 1815-2011. Pp. 397-431 in Christopher Adams, Gregg Dahl and lan Peach (Editors), Métis in Canada: History, Identity, Law and Politics. Edmonton: University of Alberta Press.

Parent, Martine. 2006a. Les ancêtres dinantais des Beaujot. Cercles d'études historiques de Gedinne. Revue 10, juin 2006, pp. 3-4.

Parent, Martine. 2006b. La famille Beaujot: De Belgique au Canada. De Gedinne à Regina. Cercles d'études historiques de Gedinne. Revue 10, juin 2006, pp. 5-44.

Rasporich, Anthony W. 2007. Utopian ideals and community settlements in Western Canada, 1880-1914. Pp. 127-154 in R. Douglas Francis and Chris Kitzan. 2007. The Prairie West as Promised Land. Calgary: University of Calgary Press.

Raiwet, Marie. 2018. Sisters of Our Lady of the Cross. The Encyclopedia of Saskatchewan. Available at: http://esask.uregina.ca/entry/sisters of our lady of the cross.html 
Rea, J.E. and Jeff Scott. 2017. Manitoba Act. The Canadian Encyclopedia. See: https://www.thecanadianencyclopedia.ca/en/article/manitoba-act

Saskatchewan Indigenous Cultural Centre, 2021. Language Department. See: www.sicc.sk.ca

Saik, Robert D., 2019. Food 5.0: How we feed the future. Lioncrest Publishers.

Robinson, Amanda and Michelle Filice. 2019. Métis Scrip in Canada. The Canadian Encyclopedia. See: https://www.thecanadianencyclopedia.ca/en/article/metis-scrip-in-canada

Savage, Candace, 2019. Strangers in the House: A Prairie Story of Bigotry and Belonging. Vancouver: Greystone Books.

Silver, A.I. 1969. French Canada and the Prairie Frontier, 1870-1890. Canadian Historical Review 50(1): 1136.

Smeets, Larry. 1980. The 'French Counts' and the origins of St. Hubert. Pp. 3-9 in Memories of St. Hubert 1980.

Smith, David E. 2010. Federalism and the Constitution of Canada. Toronto: University of Toronto Press.

Spasoff, Paul. 2005. Back to the Past: Celebrating Saskatchewan's People and Places. Regina: Back to the Past Publishing.

Statistics Canada, 1983. Historical Statistics of Canada: Section M-Agriculture. Statistics Canada Cat No. 11-516-X, archived on 29 July 1999.

Statistics Canada. 2009. Population by selected ethnic origins, by province and territory (2006 Census). Modified on 28 July 2009.

Statistics Canada. 2017. English, French and official language minorities in Canada. Census in Brief: Analytic Products, 2016 Census, released on 31 August 2017.

Statistics Canada. 2019. The French Language in Saskatchewan, 2001 to 2016: Facts and Figures. Statistics Canada Cat. No. 89-657-X2019015

Sterckx, Marjan. 2008. The Invisible "Sculpteuse": Sculptures by Women in the Nineteenth-Century Urban Public Space - London, Paris, Brussels. Nineteenth-Century Art Worldwide 7(2): 21 pp.

Sullivan, Kristian Ira William. 2009. The French Counts of St. Hubert: An Archaeological Exploration of Social Identity. M.A. Thesis. Saskatoon: University of Saskatchewan.

Tanner, Tracey and Jim Tanner. 2015. White Bear First Nations: Historical and Current Traditional Land Use Study. Printed by Blitz Printing, Calgary, for White Bear First Nations.

Thom, Darcie. 2009. Historical landmark lost in fire. The Kipling Citizen 73(31): 1 
Thompson, Christian. 2017. Cowessess First Nation. The Encyclopedia of Saskatchewan. Available at: http://esask.uregina.ca/entry/cowessess first nation.html

Tyman, John. 1972. Patterns of Western Land Settlement. Manitoba Historical Society MHS Transactions, Series 3, Number 28. Available at: http://www.mhs.mb.ca/docs/transactions/3/landsettlement.shtml Van Outryve d'Ydewalle, 2012. Lisogne se conte ... . Published by the author at the occasion of the $250^{\text {th }}$ Anniversary of Le Château de Lisogne, 208 pages.

Waiser, Bill. 2005. Saskatchewan: A New History. Calgary: Fifth House Publishers.

Waiser, Bill. 2007. Land I can own: settling the Promised Land. Pp. 155-174 in R. Douglas Francis and Chris Kitzan. 2007. The Prairie West as Promised Land. Calgary: University of Calgary Press.

Whitewood History Book Committee. 1992. St. Hubert Hamlet. Pp. 97-103 in Whitewood and Area, 18921992. Whitewood, Saskatchewan: Whitewood Herald.

Wikipedia. 2017. The French Counts of St. Hubert, Saskatchewan. Available at: https://en.wikipedia.org/wiki/The French Counts of St Hubert, Saskatchewan

Yanko, Dave. 2012. Yves de Roffignac Was Here. Westworld: CAA Magazine: Spring 2012: 12-16.

Zenon Park History Book Committee. 1983. Zenon Park 1910-1983 Yesterday/Today Hier/Aujourd'hui. Printed by Humboldt Publishing Ltd. 


\begin{tabular}{l|l|} 
Back Cover & $\begin{array}{l}\text { Roderic Beaujot is Emeritus Professor of Sociology at the University of } \\
\text { Western Ontario. He is the author of many books and articles } \\
\text { including Growth and Dualism: The Demographic Development of } \\
\text { Canadian Society (with Kevin McQuillan, Gage 1982), Population } \\
\text { Change in Canada: The Challenges of Policy Adaptation (Oxford, 1991), } \\
\text { Earning and Caring in Canadian Families (Broadview, 2000) and } \\
\text { Population Change in Canada (with Don Kerr, } 2^{\text {nd }} \text { Edition 2004, } 3^{\text {rd }} \\
\text { Edition 2016, Oxford). }\end{array}$ \\
\hline
\end{tabular}

Roderic Beaujot was President of the Federation of Canadian Demographers (1987-90), President of the Canadian Population Society (2000-02), Chair of Statistics Canada's Advisory Committee on Demographic Statistics and Studies (1994-2016), Member of the Canadian Delegation to the International Conference on Population and Development (Cairo, 1994), and member of the founding board of Action Canada for Population and Development (1997-2002).

He was awarded the 2001 John Porter Tradition of Excellence Book Award of the Canadian Sociological Association for Earning and Caring in Canadian Families, and the 2015 Lifetime Achievement Award of the Canadian Population Society.

Born in Whitewood, Saskatchewan, Roderic Beaujot started his education at Golden Plain School of the Rural Municipality of Silverwood No. 123, continuing at Collège Mathieu (Gravelbourg, Sask) and University of Alberta (PhD 1975). Married to Elisabeth née van der Meer in 1974, they have three children: Ariel, Natalie and Damien.

\section{From the Forward by Henry Gobeil:}

This book is an historical document, a genealogy, and a narration of a Saskatchewan farm family in the $20^{\text {th }}$ century.

The central theme of this book is the family of Leon and Dorothy Beaujot, but like a river that flows in time, it has tributaries nourishing this family unit: the Beaujot, Sénéchaud, Mullie and Smets ancestral origins.

It's a story of adaptation, of learning the secrets of the land, learning nature's ways, and through trial and error, developing the best practices of managing land and beast.

This is a family to learn from and to emulate: their democratic parenting style, involving everyone in decision-making, the cooperative approach to farming, the family traits of record keeping, documenting, identifying lessons learned, critical analysis, and making improvements.

Bertheline Sénéchaud, Leon's mother, is my heroine. I admire the courage this young girl had, absconding from home, from family and country, to take on this huge adventure on her own: sailing to Canada, to meet and marry a man she'd love. 